\title{
Pacific Northwest Laboratory Annual Report for 1981 to the DOE Office of Energy Research
}

Part 2 Ecological Sciences February 1982

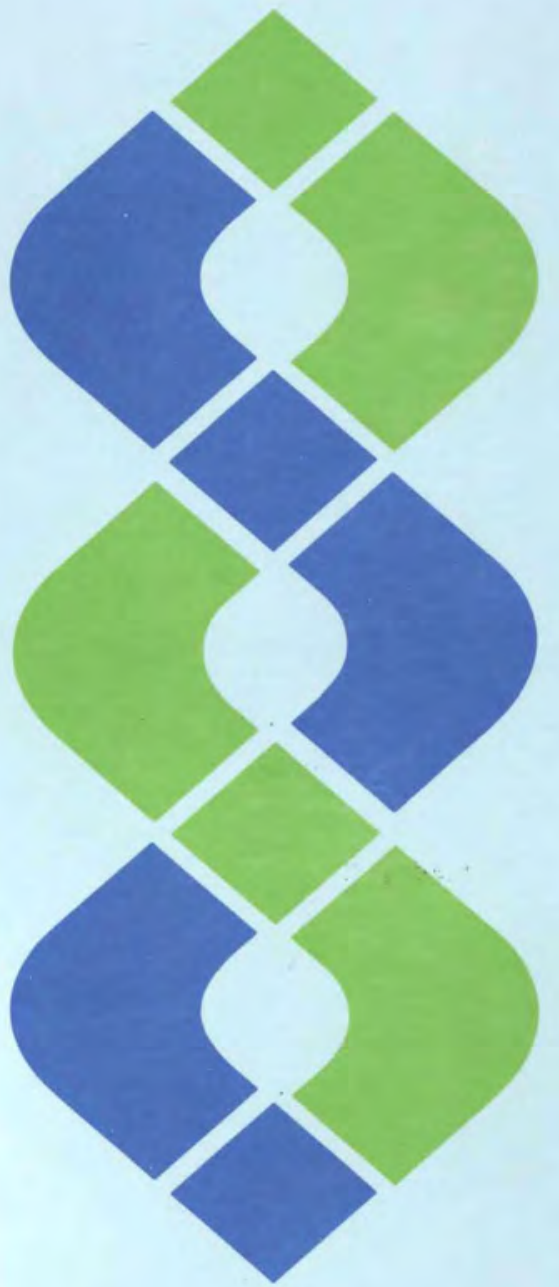

Prepared for the U.S. Department of Energy under Contract DE-AC06-76RLO 1830

Pacific Northwest Laboratory Operated for the U.S. Department of Energy by Battelle Memorial Institute 
NOT I C E

This report was prepared as an account of work sponsored by the United States Government. Neither the United States nor the Department of Energy, nor any of their employees, nor any of their contractors, subcontractors, or their employees, makes any warranty, express or implied, or assumes any legal liability or responsibility for the accuracy, completeness or usefulness of any information, apparatus, product or process disclosed, or represents that its use would not infringe privately owned rights.

The views, opinions and conclusions contained in this report are those of the contractor and do not necessarily represent those of the United States Government or the United States Department of Energy.

\author{
PACIFIC NORTHWEST LABORATORY \\ operated by \\ BATTELLE \\ for the \\ UNITED STATES DEPARTMENT OF ENERGY \\ under Contract DE-AC06-76RLO 1830
}

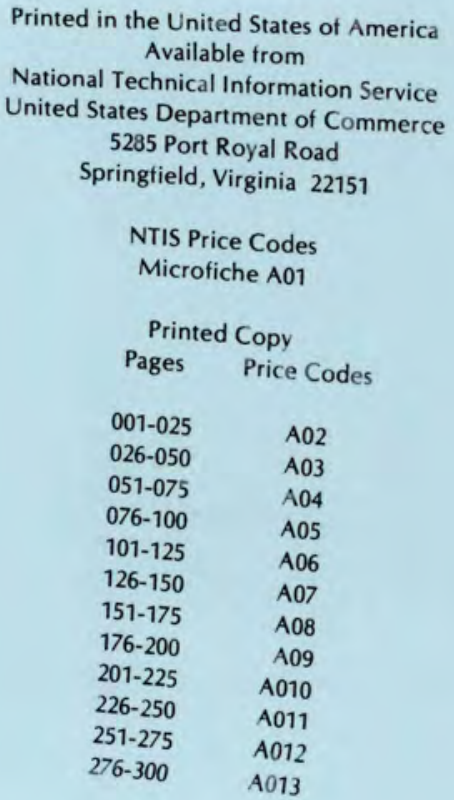




\section{Pacific Northwest Laboratory Annual Report for 1981 to the DOE Office of the Assistant Secretary for Environmental Protection, Safety, and Emergency Preparedness}

\section{Part 2 Ecological Sciences}

B. E. Vaughan and Staff Members of Pacific Northwest Laboratory

February 1982

Prepared for the U.S. Department of Energy under Contract DE-AC06-76RLO 1830

Pacific Northwest Laboratory

Richland, Washington 99352 
. 


\section{PREFACE}

This 1981 annual report from Pacific Northwest Laboratory (PNL) to the Department of Energy (DOE) describes research in environment, health, and safety conducted during fiscal year 1981. The report again consists of five parts, each in a separate volume.

The five parts of the report are oriented to particular segments of our program. Parts 1 to 4 report on research performed for the DOE Office of Health and Environmental Research in the Office of Energy Research. Part 5 reports progress on all research performed for the Office of the Assistant Secretary for Environmental Protection, Safety and Emergency Preparedness. Each part consists of project reports authored by scientists from several PNL research departments, reflecting the interdisciplinary nature of the research effort. Project reports in Parts 1 to 4 are organized primarily by energy technology.

The parts of the 1981 Annual Report are:

Part 1: Biomedical Sciences

Program Manager - H. Drucker D. L. Felton, Editor

Part 2: Ecological Sciences

Program Manager - B. E. Vaughan B. E. Vaughan, Report Coordinator

C. M. Novich, Editor

Part 3: Atmospheric Sciences

Program Manager - C. E. Elderkin $\quad$ R. L. Drake, Report Coordinator

N. M. Burleigh, Editor

Part 4: Physical Sciences

Program Manager - J. M. Nielsen

J. M. Nielsen, Report Coordinator

I. D. Hays, Editor

Part 5: Environmental and Occupational

Protection, Assessment, and Engineering

Program Managers - D. L. Hessel

W. A. Glass, Report Coordinator

S. Marks

R. W. Baalman, Editor

W. A. Glass

Activities of the scientists whose work is described in this annual report are broader in scope than the articles indicate. PNL staff have responded to numerous requests from DOE during the year for planning, for service on various task groups, and for special assistance. 
The topic of the 21st Hanford Life Sciences Symposium, which was held this year, was "Biological Availability of Trace Metals: Chemical Estimation, Ecological and Health Implications."

A highlight of the year was completion of the third floor of the office wing of the Life Sciences Laboratory. This opens up substantial laboratory space by allowing investigators to move offices from the laboratory to the new area.

Credit for this annual report goes to many scientists who performed the research and wrote the individual project reports, to the program managers who directed the research and coordinated the technical progress reports, to the editors who edited the individual project reports and assembled the five parts, and to Ray Baalman and Irene D. Hays, editors in chief, who directed the total effort. The size of this year's report has been reduced as the result of an effort to report more fully in the open literature.

W. J. Bair, Manager

S. Marks, Associate Manager

Environment, Health and Safety Research

Program

Previous Reports in this series:

Annual Report for

$\begin{array}{ll}1951 & \text { W-25021, HW-25709 } \\ 1952 & \text { HW-27814, HW-28636 } \\ 1953 & \text { HW-30437, HW-30464 } \\ 1954 & \text { HW-30306, HW-33128, HW-35905, HW-35917 } \\ 1955 & \text { HW-39558, HW-41315, HW-41500 } \\ 1956 & \text { HW-47500 } \\ 1957 & \text { HW-53500 } \\ 1958 & \text { HW-59500 } \\ 1959 & \text { HW-63824, HW-65500 } \\ 1960 & \text { HW-69500, HW-70050 } \\ 1961 & \text { HW-72500, HW-73337 } \\ 1962 & \text { HW-76000, HW-77609 } \\ 1963 & \text { HW-80500, HW-81746 } \\ 1964 & \text { BNWL-122 } \\ 1965 & \text { BNWL-280; BNWL-235, Vol. 1-4; BNWL-361 } \\ 1966 & \text { BNWL-480, Vol. 1; BNWL-481, Vol. 2, Pt. 1-4 } \\ 1967 & \text { BNWL-714, Vol. 1; BNWL-715, Vol. 2, Pt. 1-4 }\end{array}$


$\begin{array}{ll}1968 & \text { BNWL-1050, Vol. 1, Pt. 1-2; BNWL-1051, Vol. 2, Pt. 1-3 } \\ 1969 & \text { BNWL-1306, Vol. 1, Pt. 1-2; BNWL-1307, Vol. 2, Pt. 1-3 } \\ 1970 & \text { BNWL-1550, Vol. 1, Pt. 1-2; BNWL-1551, Vol. 2, Pt. 1-2 } \\ 1971 & \text { BNWL-1650, Vol. 1, Pt. 1-2; BNWL-1651, Vol. 2, Pt. 1-2 } \\ 1972 & \text { BNWL-1750, Vol. 1, Pt. 1-2; BNWL-1751, Vol. 2, Pt. 1-2 } \\ 1973 & \text { BNWL-1850, } \\ 1974 & \text { BNWL-7t. 1-4 } \\ 1975 & \text { PNWWL-2000, Pt. 1-4 } \\ 1976 & \text { BNWL-2100, Pt. 1-5 } \\ 197 & \\ 1 / 7 & \text { PNL-2500, Pt. 1-5 } \\ 1978 & \text { PNL-2850, Pt. 1-5 } \\ 1979 & \text { PNL-3300, Pt. 1-5 } \\ 1980 & \text { PNL-3700, Pt. 1-5 }\end{array}$ 


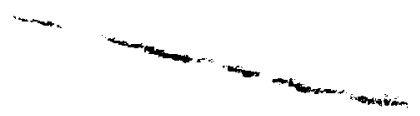




\section{FOREWORD}

This volume of the Annual Report describes PNL's work in the ecological sciences funded by the Office of Energy Research (OER) in the following budget activity categories:

$\mathrm{H}$-Environment

A-Multi-Resource

HA-02-03-01 - Identification, Transport and Conversion of Energy-Related Pollutants in the Environment

HA-02-03-02 - Environmental Effects of Energy-Related Processes and Pollutants in the Environment

HA-02-03-03 - Enery-Related Supporting Research

HA-02-03-04 - Environmental Operations and DOE Support Activities

For convenience, organization charts for the several participating departments and sections of PNL can be found at the back of the report.

Where appropriate, we have grouped the individual research projects (Field Task Proposals, Form 5120) according to the energy areas to which they are most relevant. Principal investigators listed may be contacted for further information about individual projects. We hope this format makes the report useful, not only to OER but to budgeting managers and others concerned with program support. The reader should note that progress reports for several research programs (biomedical effects, atmospheric dispersal, and chemical characterization) are reported in separate volumes of this Annual Report (see Preface). These programs include the Synfuels (Section 4), Nuclear (Section 5), Electromagnetic Field (Section 10), and Pathways Modeling (Section 9) research efforts.

The ecological programs described herein are designed to anticipate problems in meeting the intent of the National Environmental Policy Act. Such problems, "around-the-corner," should be systematically evaluated before major capital investment is committed by industry. As regards theoretical studies described in Sections 1 and 9 of this report, many current estimates of ecological processes are quantitatively provisional, without statistical basis, and suited only as order-of-magnitude estimates. Too frequently risk is thereby overestimated. In these areas, it is in the interest of technologists that a groundwork be laid for quantiatively meaningful data, especially where the data are likely to be used by agencies responsible for setting standards. 
PNL's industrial experience with the oil, synfuels and shale developments, and with other agencies concerned with energy installations, has contributed in a particularly pertinent way to the understanding of environmental problems requiring timely assistance. However, not all such work is reported herein. Projects funded specifically on the basis of contract with Battelle, or by interagency agreement with DOE, are listed for reference in Section 11 of th is report. Descriptions of these latter projects will be found in a separate annual report(a). A listing of all published studies will be found in the Ecological Sciences Department bibliography.(b) The bibliography will be updated this year. In the meantime, a fairly complete list of our publication activity is available at the end of this report and in our other annual report.(a)

During 1981, construction commenced on the new Battelle laboratory at Sequim, Washington, and it is nearing completion at this time. The six-million-dollar expansion will approximately double the size of the present office, laboratory, and wet laboratory facilities used by PNL's Marine Sciences Section. With the Northern Tier Pipeline and other new energy developments in the Pacific Northwest, the decision to expand the Marine Research Laboratory reflects our confidence that regional research needs will continue to be met.

Staff scientific activities at a national level included the following:

\section{American Nuclear Society}

E. C. Watson: Working Group 2.15/2.16 (Standard Methods of Analysis of Atmospheric Transport of Routine/Accidental Release of Nuclear Reactor Effluent), member.

American Society for Testing and Materials (ASTM) .

C. D. Becker: Task Group on Procedures for Acute Tests with Dispersants and Oil, member

T. M. Poston: Committee E-47. Toxicity Testing, member.

Bureau of Land Management

J. W. Anderson: Scientific Advistory Committee for Research on the Studies Program for the Outer Continental Shelf, member

Federal Marine Mammal Commission

L. Lee Eberhardt: Com. Scientific Advisors, member

International Atomic Energy Agency

W. L. Templeton: Consultant Group on Safety Series \#5 (Disposal of Radioactivity into the Oceans), member

\section{International Standards Organization}

Edwin C. Watson: Working Group 7, Tech. Com. 85/5

National Academy of Sciences

Jack W. Anderson: Fate and Effects of Petroleum on the Marine Environment, member

L. Lee Eberhardt: Com. Free-Roaming Wild Horses \& Burros, member 
Evertt A. Jenne: Com. on Geochemistry, member

Raymond E. Wildung: Com. Accessory (Trace Elements); Oil Shale Panel, Chairman; Com. Soil as Mineral Resource (Bd. of Mineral Resources), member

\section{National Council on Radiation Protection}

David A. Baker: Sci. Com. 64, Task Group 3, member

Joe K. Soldat: Scientific Committee 38, Task Group on lodine-129; member

William L. Templeton: Sci. Com. 64, Chairman, Task Group 2

Edwin C. Watson: Scientific Committee 38, Task Group on TMI Accident-Generated Waste Water, member

\section{National Oceanographic \& Atmospheric Administration}

Jack W. Anderson: Interagency Com. Ocean Pollution Research, Development \& Monitoring, panel member

\section{Organization for Economic Cooperation and Development/Nuclear Energy Agency}

W. L. Templeton: Executive Group for Research on Sea Disposal of Radioactive Waste, chairman

UN Educational and Scientific and Cultural Organization

W. L. Templeton: Committee on Health of the Oceans (Scientific Aspects of Marine Pollution), member

In addition, several staff members served as editors or associate editors of various learned journals (Colbert E. Cushing, Ecology; C. Dale Becker, Trans. Amer. Fish. Soc.; Guri Roesijadi and Jack W. Anderson, Marine Environ. Res.).

Burton E. Vaughan Subprogram Manager Ecological Sciences

(a) Annual Report for 1981 on Interagency/Contract Research, Ecological Sciences Department. Battelle, Pacific Northwest Laboratories, Richland, WA 99352.

(b) Bibliography of Environmental Research. PNL-SA-4655, Rev. No. 5, Ecological Sciences Department, Pacific Northwest Laboratory, Richland, WA 99352. 
.

. 


\section{CONTENTS}

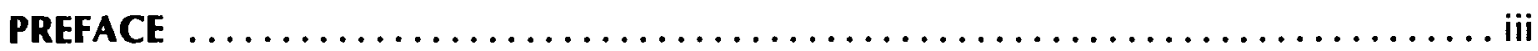

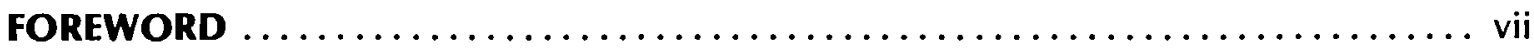

NATIONAL ENVIRONMENTAL RESEARCH PARK AND LAND USE

NATIONAL ENVIRONMENTAL RESEARCH PARK $\ldots \ldots \ldots \ldots \ldots \ldots \ldots \ldots \ldots$

LAND DISTURBANCE AND NATIVE BIOTA OF THE HANFORD NERP $\ldots \ldots \quad 1$

ECOLOGICAL BEHAVIOR OF IODINE ON THE HANFORD NERP $\ldots \ldots \ldots \ldots 2$

HANFORD WILDLIFE STUDIES ...................... 5

GRADUATE STUDENT RESEARCH ..................... 6

UPTAKE OF TRACE ELEMENTS BY SAGEBRUSH FROM EXPERIMENTALLY

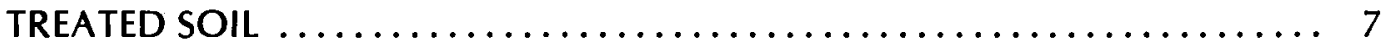

CATION CONTENT OF THE LEAVES OF DESERT SHRUBS AND ITS

RELATIONSHIP TO TAXONOMIC AND ECOLOGIC CLASSIFICATION .... 7

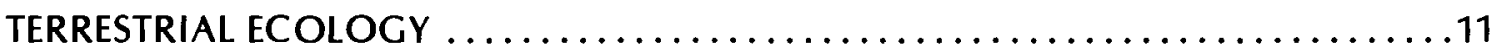

EFFECTS OF FIRE AND CLIPPING ON BLUEBUNCH WHEATGRASS . . . . . 11

BIRDS OF PRISTINE AND OLD-FIELD COMMUNITIES ON THE

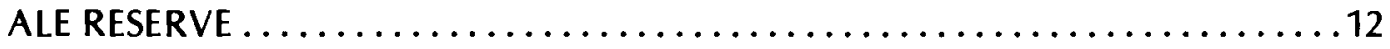

COLONY DENSITY AND ACTIVITY OF THE ANT,

CAMPONOTUS SEMITESTACEUS, IN A SHRUB-STEPPE COMMUNITY . . . . 12

COMP.ARISON OF SMALL-MAMMAL ABUNDANCE IN

SHRUB-STEPPE COMMUNITIES ...................... 13

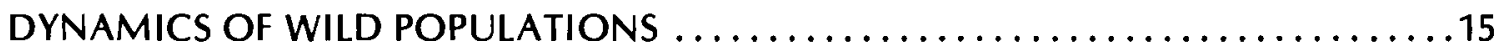

QUANTIFYING ENERGY-RELATED EFFECTS ON MOBILE SPECIES $\ldots \ldots \ldots \ldots \ldots \ldots$

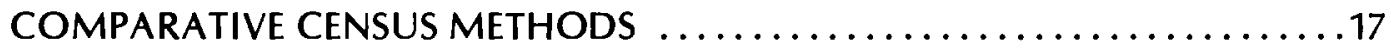

TESTS OF TREATMENT EFFECTS . . . . . . . . . . . . . . . . . 18

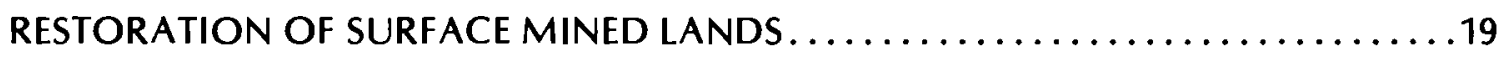

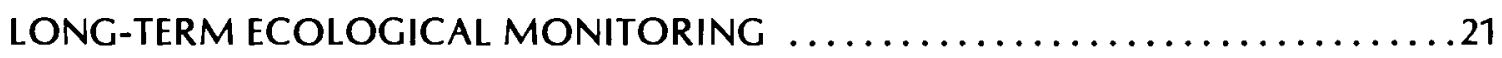

MONITORING DESIGN AND DEVELOPMENT . . . . . . . . . . . . 21

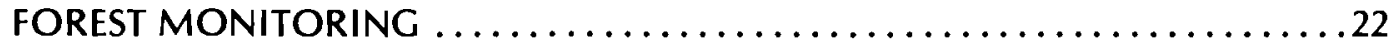

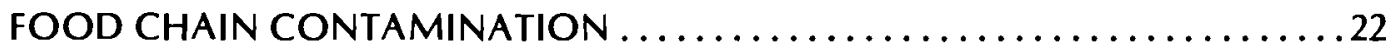

APPLICATION OF LONG-TERM CHEMICAL BIOBARRIERS FOR U-TAILINGS ... 25 
DEVELOPMENT OF POLYMERIC CARRIER/DELIVERY (PCD) SYSTEMS AND DETERMINATION OF HERBICIDE RELEASE RATES ................. 25

PHYTOTOXICITY AND DEGRADATION STUDIES .................. 26

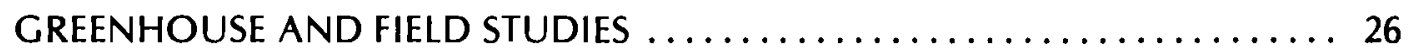

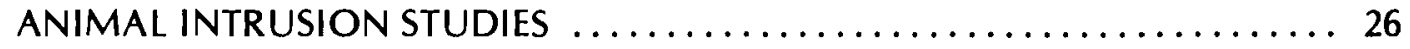

REVEGETATION/ROCK COVER FOR STABILIZATION OF INACTIVE

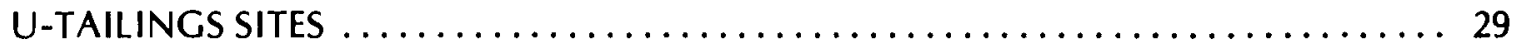

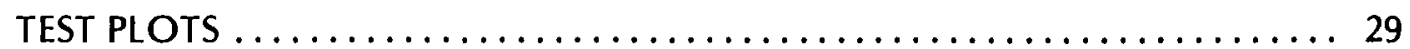

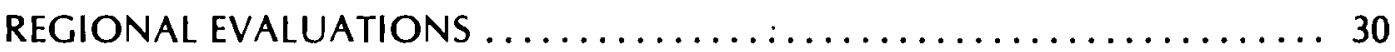

MODELING ........................................ 31

ALASKAN RESOURCE RESEARCH

ECOLOGICAL INVESTIGATION OF ALASKAN RESOURCE DEVELOPMENT ...... 37

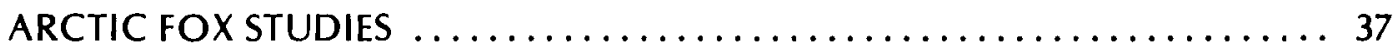

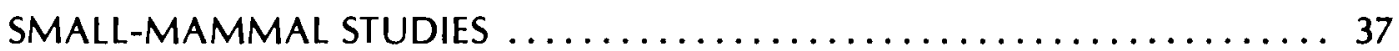

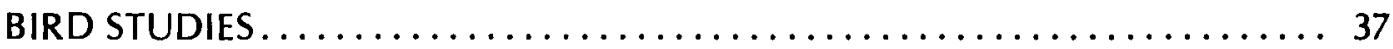

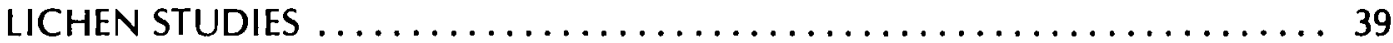

RADIATION ECOLOGY STUDIES $\ldots \ldots \ldots \ldots \ldots \ldots \ldots \ldots \ldots \ldots \ldots, 39$

SHALE OIL

TERRESTRIAL EFFECTS OF OIL SHALE DEVELOPMENT $\ldots \ldots \ldots \ldots \ldots \ldots \ldots \ldots 45$

WASTE PROCESSES CONTROLLING LEACHATE CHEMISTRY .......... 45

INTERACTION OF RETORTED SHALE LEACHATES WITH LINERS

AND SUBSTRATA $\ldots \ldots \ldots \ldots \ldots \ldots \ldots \ldots \ldots \ldots \ldots \ldots \ldots \ldots, 46$

HYDROLOGIC PROCESSES CONTROLLING LEACHATE MOVEMENT _.... 47

SOURCE AND BEHAVIOR OF ORGANIC SUBSTANCES ............. 48

ENVIRONMENTAL STUDIES AT THE RIO BLANCO SITE, TRACT C-a ...... 51

ENVIRONMENTAL STUDIES AT THE DOE RIFLE OIL SHALE FACILITY-

GEOCHEMICAL MODELING $\ldots \ldots \ldots \ldots \ldots \ldots \ldots \ldots \ldots \ldots \ldots \ldots \ldots \ldots \ldots$

\section{SYNFUELS}

ECOLOGICAL EFFECTS OF COAL CONVERSION $\ldots \ldots \ldots \ldots \ldots \ldots \ldots \ldots \ldots . \ldots 5$

CHEMICAL CHARACTERIZATION AND FATE .................... 59

ECOLOGICAL FATE AND EFFECTS $\ldots \ldots \ldots \ldots \ldots \ldots \ldots \ldots \ldots \ldots \ldots \ldots \ldots \ldots \ldots$

ENVIRONMENTAL PATHWAYS MODELING $\ldots \ldots \ldots \ldots \ldots \ldots \ldots \ldots, 67$ 
COAL LIQUEFACTION HEALTH AND ENVIRONMENTAL EFFECTS

DOCUMENT (HEED)

\section{NUCLEAR WASTE: FISSION}

TRANSURANIC ELEMENT BEHAVIOR IN SOILS AND PLANTS $\ldots \ldots \ldots \ldots \ldots \ldots 77$

INFLUENCE OF NEPTUNIUM CONCENTRATION ON

PLANT AVAILABILITY ................................ 77

PLANT METABOLISM OF NEPTUNIUM IN SOYBEAN AND ALFALFA . . . . 78

TRANSURANIC CHEMICAL SPECIES IN GROUND WATERS $\ldots \ldots \ldots \ldots \ldots \ldots \ldots 1$

QUANTITATIVE ASPECTS OF TRANSURANIC AND OTHER RADIONUCLIDE

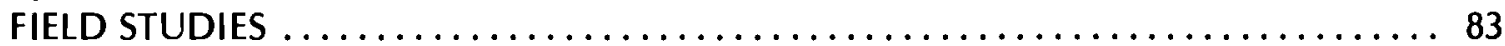

TRAN-STAT: STATISTICS FOR ENVIRONMENTAL CONTAMINANT

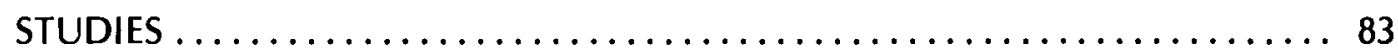

DECOMMISSIONING AND DECONTAMINATION GUIDE ........... 83

COMPUTER SIMULATION OF RATIO ESTIMATORS .............. 83

OTHER ACTIVITIES $\ldots \ldots \ldots \ldots \ldots \ldots \ldots \ldots \ldots \ldots \ldots \ldots \ldots \ldots \ldots$

ANALOG ELEMENTS FOR TRANSURANIC CHEMISTRIES $\ldots \ldots \ldots \ldots \ldots \ldots \ldots \ldots$

BEHAVIOR OF ANALOG AND TRANSURANIC ELEMENTS IN

THE ENVIRONMENT .............................. 85

RARE EARTH ELEMENT ANALYSIS BY RADIOCHEMICAL

NEUTRON ACTIVATION $\ldots \ldots \ldots \ldots \ldots \ldots \ldots \ldots \ldots \ldots \ldots \ldots \ldots \ldots$

LONG-TERM PLANT AVAILABILITY OF ACTINIDES ................ 89

ROUTINE MAINTENANCE $\ldots \ldots \ldots \ldots \ldots \ldots \ldots \ldots \ldots \ldots \ldots \ldots \ldots$

DATA MANAGEMENT SYSTEM $\ldots \ldots \ldots \ldots \ldots \ldots \ldots \ldots \ldots \ldots$

RADIOECOLOGY OF NUCLEAR FUEL CYCLES $\ldots \ldots \ldots \ldots \ldots \ldots \ldots \ldots \ldots \ldots$

BIOTIC TRANSPORT PARAMETERS $\ldots \ldots \ldots \ldots \ldots \ldots \ldots \ldots \ldots \ldots \ldots \ldots$

AQUATIC RADIOECOLOGY . ...................... 93

TERRESTRIAL RADIOECOLOGY ........................ 94

ENVIRONMENTAL BEHAVIOR OF TECHNETIUM-99 AND IODINE-129 . . . . . 97

CYCLING OF ${ }^{99}$ TC AND ${ }^{129}$ I WITHIN THE BOUNDARIES OF A

HANFORD FUELS REPROCESSING FACILITY .................. 97

BIOLOGICAL BEHAVIOR OF TECHNETIUM ............... 97

AVAILABILITY OF PLANT-INCORPORATED ${ }^{99} \mathrm{TC} \mathrm{AND}^{99} \mathrm{TCO}_{4}^{-}$

TO ANIMALS $\ldots \ldots \ldots \ldots \ldots \ldots \ldots \ldots \ldots \ldots \ldots \ldots \ldots \ldots \ldots \ldots . . \ldots \ldots$ 


\section{MARINE RESEARCH PROGRAM}

TRACE METALS METABOLISM IN MARINE ANIMALS . . . . . . . . . . . . 105

LOW MOLECULAR WEIGHT, MERCURY-BINDING PROTEINS IN THE MARINE MUSSEL . . . . . . . . . . . . . . . . . . . . . . . . . . . . . . 105

ENHANCED TOLERANCE OF MUSSELS TO MERCURY TOXICITY ....... 105 IMMUNOLOGICAL ASSAYS FOR LOW MOLECULAR WEIGHT,

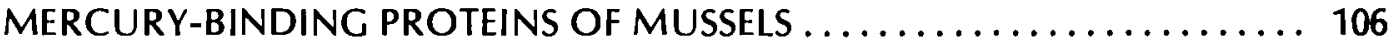

FIELD STUDIES: TRACE METALS IN MARINE MUSSELS . . . . . . . . . . 107

EFFECTS OF COPPER ON THE POLYCHAETE, EUDISTYLIA VANCOUVERI ................................ 107

BIOAVAILABILITY OF ENERGY-EFFLUENT MATERIALS IN

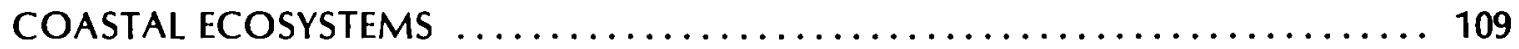

EFFECTS OF SEA-SURFACE MICROLAYER PROCESSES ON THE BIOAVAILABILITY OF ANTHROPOGENIC SUBSTANCES ............ 109

EFFECTS OF MARINE SEDIMENT AND INTERSTITIAL WATER ON BIOAVAILABILITY OF CADMIUM .......................... 110

INFLUENCE OF SULFIDE ON Cd BIOAVAILABILITY .............. 112

BIOACCUMULATION KINETICS AND ORGAN DISTRIBUTION OF NICKEL IN A MARINE CLAM ............................. 112 MICROBIAL SOLUBILIZATION OF TRACE METALS IN MARINE SEDIMENTS .................................. 114

MARINE CHEMISTRY OF ENERGY-RELATED POLLUTANTS . . . . . . . . . . . . . 115 SOLUBILITY BEHAVIOR OF ATMOSPHERIC 'Be IN THE MARINE ENVIRONMENT ................................ 115

ELECTROCHEMICAL ANALYSIS OF SULFIDE IN NATURAL WATERS . . . . 116 ATMOSPHERIC DEPOSITION RATE OF METALS AND PAH IN

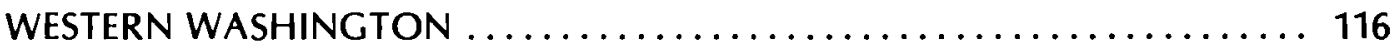

COORDINATION: PACIFIC MARINE SCIENCE PROGRAM .............. 119

\section{NUCLEAR FUSION}

SUBLETHAL EFFECTS OF TRITIUM ON AQUATIC SYSTEMS $\ldots \ldots \ldots \ldots \ldots \ldots \ldots . \ldots \ldots$

RELATIVE BIOLOGICAL EFFECTIVENESS OF ${ }^{3} \mathrm{HOH} \ldots \ldots \ldots \ldots \ldots \ldots \ldots . \ldots$ COMPARISON OF TUBE AGGUTINATION AND MICROTITER TECHNIQUES ............................... 125 MITOGEN STUDIES .................................... 125 
ECOLOGICAL EFFECTS OF LITHIUM AND BERYLLIUM ON

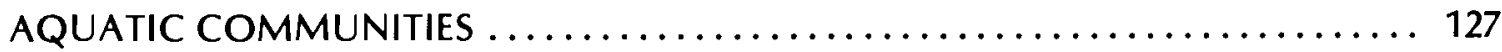

TERATOGENIC EFFECTS OF LOW-LEVEL MAGNETIC FIELDS .............. 129

EFFECTS OF MAGNETIC FIELD EXPOSURE ON FERTILIZATION OF RAINBOW TROUT, SALMO GAIRDNERI .................... 129

LATENT EFFECTS OF MAGNETIC FIELD AND CHLORINE EXPOSURE ON GROWTH OF JUVENILE RAINBOW TROUT, SALMO GAIRDNERI _... 130

PUMPED STORAGE AND HYDROELECTRIC DEVELOPMENT

EFFECTS OF HYDROELECTRIC GENERATION ON RIVERINE ECOLOGY ........ 137

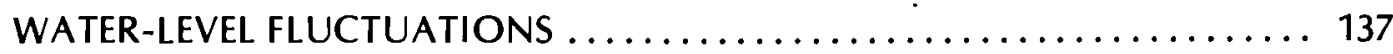

SALMON REDD DEWATERING ............................ 138

PATHWAYS MODELING, ASSESSMENT AND HANFORD PROJECT SUPPORT ASSESSMENT OF EFFECTIVENESS OF GEOLOGIC ISOLATION SYSTEMS ........ 145

DOSE METHODOLOGY DEVELOPMENT ..................... 145

SALT DOME RSIA ................................... 145

HANFORD DEFENSE WASTE STUDIES $\ldots \ldots \ldots \ldots \ldots \ldots \ldots \ldots \ldots \ldots \ldots \ldots \ldots$

WASTE DISPOSAL GUIDANCE ............................. 147

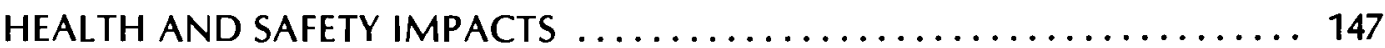

SERVICE ASSESSMENT STUDIES .............................. 149

FALL CHINOOK SALMON SPAWNING NEAR HANFORD, $1980 \ldots \ldots \ldots \ldots 150$

BALD EAGLE STUDIES .................................. 150

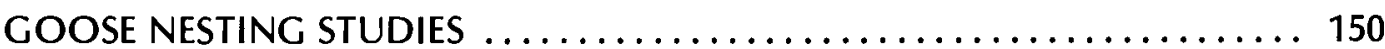

POWER PLANT FUEL CONVERSION ENVIRONMENTAL IMPACT ASSESSMENT . . 151

STANDARD HANFORD DOSE METHODOLOGIES $\ldots \ldots \ldots \ldots \ldots \ldots \ldots \ldots . \ldots \ldots$

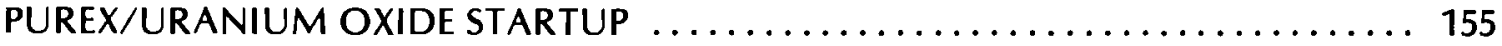

REVIEW OF SOIL CONTAMINATION GUIDANCE $\ldots \ldots \ldots \ldots \ldots \ldots \ldots \ldots \ldots . \ldots \ldots$

PRELIMINARY RADIATION DOSE ANALYSIS FOR REFERENCE

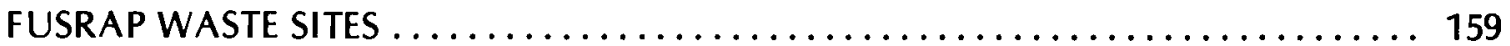

ENVIRONMENTAL ASSESSMENT FOR ADVANCED ISOTOPE SEPARATION ..... 161

ELECTRIC FIELD RESEARCH

BIOLOGICAL STUDIES OF A 1200-kV PROTOTYPE TRANSMISSION SYSTEM 


\section{ENERGY-RELATED RESEARCH FOR OTHER AGENCIES}

ARGONNE NATIONAL LABORATORY $\ldots \ldots \ldots \ldots \ldots \ldots \ldots \ldots \ldots \ldots \ldots \ldots \ldots$

ENVIRONMENTAL PROTECTION AGENCY .................. 171

KNOLLS ATOMIC POWER LABORATORY ................... 171

NATIONAL INSTITUTE OF ENVIRONMENTAL AND HEALTH SCIENCES . . . 171

NATIONAL OCEANOGRAPHIC AND ATMOSPHERIC

ADMINISTRATION ................................... 171

NATIONAL SCIENCE FOUNDATION $\ldots \ldots \ldots \ldots \ldots \ldots \ldots \ldots \ldots \ldots \ldots \ldots$

NUCLEAR REGULATORY COMMISSION .................... 171

PUGET SOUND POWER \& LIGHT COMPANY/NORTHWEST ENERGY

SERVICES COMPANY ............................. 172

U.S. FISH \& WILDLIFE SERVICE .................... 172

PUBLICATIONS AND PRESENTATIONS $\ldots \ldots \ldots \ldots \ldots \ldots \ldots \ldots \ldots \ldots \ldots \ldots \ldots \ldots \ldots \ldots \ldots$

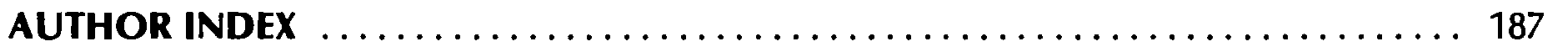

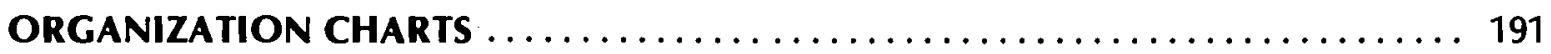

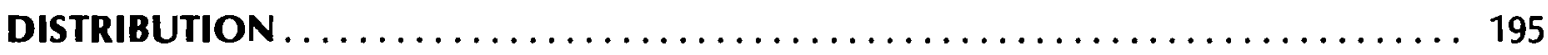




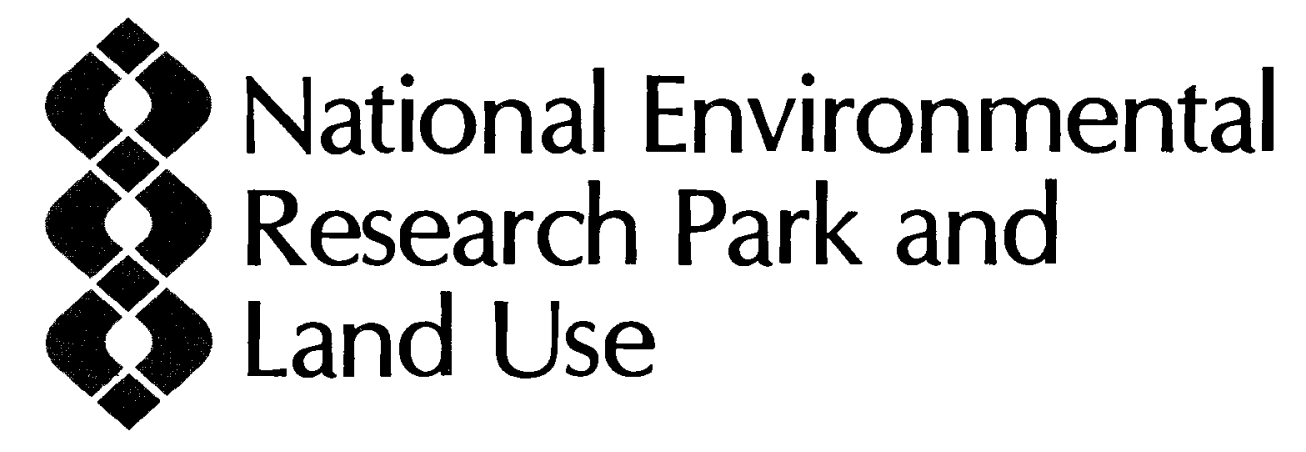




\section{NATIONAL. ENVIRONMENTAL. RESEARCH PARK AND LAND USE}

- National Environmental Research Park

- Terrestrial Ecology

- Dynamics of Wild Populations

- Quantifying Energy-Related Effects on Mobile Species

- Restoration of Surface-Mined Lands

- Long-Term Ecological Monitoring

- Application of Long-Term Chemical Biobarriers for U-Tailings

- Revegetation/Rock Cover for Stabilization of Inactive U-Tailings Sites

Nuclear energy research and development sometimes requires large land holdings. One of the most strategically situated of these is the Hanford site in the state of Washington. The Hanford site currently contains the now obsolete facilities developed for wartime plutonium production, and it also safely stores large amounts of radioactive waste materials. As a health and safety measure, these facilities are surrounded by large land areas unoccupied by people. Today, these buffer zones provide some of the best protected and, therefore, most useful land for long- and short-term terrestrial ecological research. In recognition, the Arid Lands Ecology (ALE) Reserve and the Hanford National Environmental Research Park (NERP) were established to promote the use of the Hanford site for ecological research, especially studies related to developing energy technologies and to mitigate energy development impacts in arid and semi-arid regions.

The terrestrial ecology studies being conducted on the Hanford site provide information concerning short- and long-term impacts of construction and operation of energy facilities. These studies provide the kind of information needed to comply with the intent of the National Environmental Policy Act (NEPA) and various congressional acts pertaining to wildlife, apart from advancing the state of ecological knowledge in the scientific community at large. For example, land restoration studies of areas located in Washington, Colorado and Arizona, which will terminate in FY 1981, were designed to test more cost-effective ways to successfully revegetate surfacemined lands in arid climates. Also, for example, some airborne and liquid effluents of energy facilities are not confined to the land holdings of any particular state, federal or private ownership and are dispersed widely over regional landscapes. Air pollution is one example where impact may be more directly assessed by damage to vegetation. Methods are under investigation to develop quantitative tools for monitoring the long-term damaging effects of air pollution. The Pacific Northwest is one of the most ecologically diverse regions in North America, so numerous methods are under development. 


\title{
- National Environmental Research Park
}

\author{
Principal Investigator: W. H. Rickard
}

The Hanford NERP, one of five National Research parks, contains ecosystems representative of North American semi-arid steppes. Work funded under this Schedule 5121 is designed to serve as a baseline case for predicting the magnitude and direction of biotic changes induced by man's manipulations. In FY 1981, studies were made of vegetal and animal changes that are likely to occur as a result of the Hanford industrial development. This report summarizes available information concerning vegetal and mammal populations associated with the bitterbrush-sagebrush habitat type on the Hanford site in relation to fire and land disturbances, and the future of native biota under industrial rather than agricultural land use. This report alsa summarizes the ecological behavior of elemental iodine on the Hanford site, In one experiment on the uptake of trace elements, we demonstrated trace element uptake in sagebrush plants. In another experiment, we investigated the use of the cation content of desert shrub leaves, which proved useful as a way to improve ecological classification. Also, Hanford wildlife studies and research projects conducted by graduate students as a part of Hanford NERP activities in 1981 are briefly summarized.

LAND DISTURBANCE AND NATIVE BIOTA OF THE HANFORD NERP

Once a thinly populated area, the semi-arid shrub-steppe region of western North America has been steadily urbanized, industrialized, and converted to agricultural land use. This study describes the role of industrial land use and its relationship to the conservation of native biota on the Hanford NERP.

The shrub-steppe region occupies about $16 \%$ of the semi-arid vegetation types in North America (Figure 1). Most of the region has been disturbed during the past 150 years by the activities of immigrant Europeans. Livestock grazing, vegetal management for livestock forage (i.e., planting of exotic grasses and shrub removal by fire, chemical herbicides, and mechanical means) and dryland and irrigated farming all have contributed to the demise of native biota. Although agricultural use has been intensive, industrial use of the region has been light. A few aluminum factories, usually located near hydroelectric dams, are scattered along the Snake and Columbia Rivers in Washington and Idaho. There are no stee 1 mi11s in the region, and except for the extreine eastern parts of the region (Wyoming), there are relatively few coal deposits and only a few coal-fired power plants. There are also only a few urban centers. The largest metropolitan areas are the Tri-Cities, Washington, and Boise, Idaho.

Due to their sparse human population, two sites in the shrub-steppe region were selected in the 1940s for the production of nuclear materials: Hanford, Washington; and the Idaho National Engineering Laboratory (Figure 1).

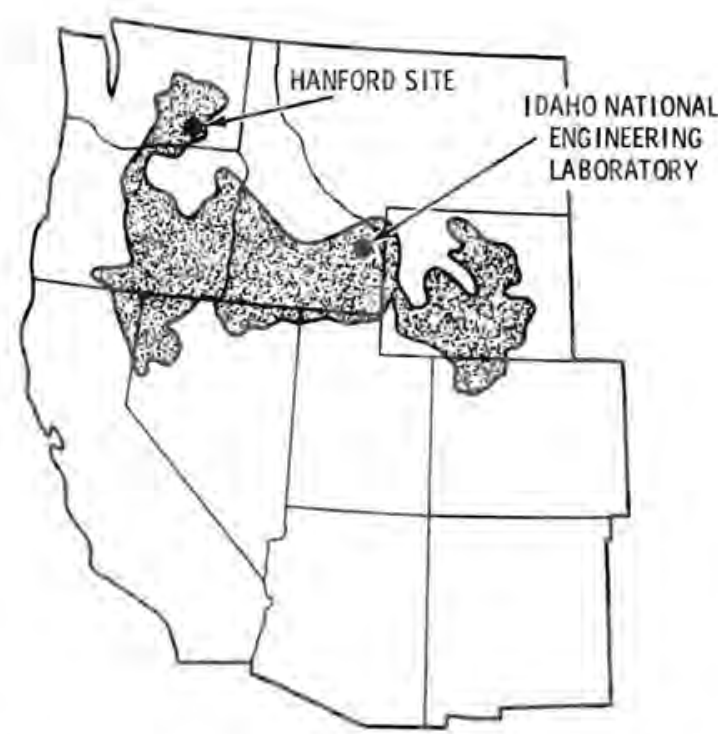

FIGURE 1. Location of the Hanford Site and INEL in the Shrub-Steppe Region

The bitterbrush-sagebrush habitat type, a variant of shrub steppe, occupies about $300 \mathrm{~km}^{2}$ in the southeastern sector of the Hanford site. Desert shrubs, sagebrush (Artemisia tridentata), and bitterbrush (Purshia tridentata), comprise most of the shrub overstory. The herb understory extending beneath and between the widely spaced shrubs consists mostly of Sandberg bluegrass, Poa sandbergii, and cheatgrass brome, Bromus tectorum. Neddleand-thread grass, Stipa comata, is sparsely represented. Whether or not $\underline{S}$. comata was an 
important constituent of the vegetation before the advent of European man to the region in the early 1800s is unknown. The grass is palatable to livestock, and it is conceivable that its demise could have been implemented by many years of overgrazing in the years prior to 1940.

Prior to 1943, cattle and sheep probably roamed freely over the Hanford site during all seasons of the year. Overgrazing may at least partly account for the destruction of native grasses and forbs, thus aiding in the invasion and establishment of an introduced European grass, cheatgrass brome. Although livestock grazing has been excluded from the Hanford site since 1943 , cheatgrass brome not only persists but usually dominates the herbaceous vegetation.

Irrigated agriculture was once practiced on land in the northern part of the bitterbrushsagebrush habitat type in the vicinity of the now abandoned townsites of Hanford and White Bluffs (Figure 2). These fields, abandoned since 1943, were promptly colonized by cheatgrass brome, which has persisted for 38 years with little or no evidence of invasion by native plants.

Three large industrial facilities are located in the bitterbrush-sagebrush vegetal type: the Fast Flux Test Facility (FFTF), three commercial nuclear power reactors (WNP 1, 2 and 4 ), and the research laboratory complex at the 300 Area (Figure 2).

Wildfire is a recurring event. Large burns $(10,000$ ha or more) occurred in 1963 and again in 1970. Smaller burns are a yearly occurrence. Sagebrush and bitterbrush are killed by burning. They do not sprout from belowground parts after being burned. However, rabbitbrush, Chrysothammus spp., has some ability to sprout after burning, and it is of ten the first shrub to reappear on burned ground. Herbaceous perennial plants are not easily killed by sumer burning and they usually recover in the first season following the burn. Seeds of annual plants are destroyed by burning, but seeds buried in the soil survive to provide new generations of annual plants. Four years after the 1970 fire, the herbaceous vegetation had attained pre-burn species composition and abundance.

It is likely that prior to the government's acquisition of the Hanford site in 1943, very few mule deer (Odocoileus heminonus) resided in the bitterbrush-sagebrush habitat type. Deer populations were probably kept at very low population levels by the resident human population in villages of Richland, White
Bluffs and Hanford. Because the economy of these villages at this time was based on agriculture, deer depredations upon crop plants were not tolerated and deer populations were probably at extremely low levels if not extirpated locally. When the villages of White Bluffs and Hanford were evacuated to provide for plutonium production facilities, the farms were also abandoned. Under the protection provided by the strict security regulations and the absence of hunting within the boundaries of the Hanford site, which encompassed about $1400 \mathrm{~km}^{2}$ of 1 and, the deer population increased.

The isolation provided by the Hanford site encouraged the population of the coyote, Canis latrans. A study of coyote predation on mule deer fawns in 1979 indicated that coyote predation was an important contributor to fawn mortality. To help protect nesting populations of wild Canada geese from coyote predation, Washington State Game Department personnel killed 268 coyotes along the Columbia River on the Hanford site in the years 1979 to 1981. The impact of coyote suppression on mule deer fawn mortality has not been studied.

Land use of the bitterbrush-sagebrush vegetal type on the Hanford site for energy development purposes over the past 40 years has been more amenable to the conservation of native shrub steppe biota than has intensive agricultural use on the surrounding land; however, the wildlife resources of the Hanford site still require study and applied management practice. Of special concern are potentially toxic chemicals released into the biosphere and their possible transport by food chains.

\section{ECOLOGICAL BEHAVIOR OF IODINE ON THE HANFORD NERP}

This report summarizes the behavior of radioactive and non-radioactive iodine in soil, wild plants, jackrabbits and mule deer on the Hanford site from a historical point of view.

Plants obtain nonradioactive iodine, 127 I, via the soil-root-shoot uptake path. Wild herbivorous mammals obtain iodine by eating a variety of wild plants, by direct ingestion of soil, and possibly through the use of natural salt licks. The 127 I content of cheatgrass, Bromus tectorum, and attendant soil at two 10cations on the Hanford site is shown in Table 1. Iodine-127 in Ritzville silt loam increased with increasing soil depth. The iodine content of Rupert sand averaged $0.58 \mathrm{ppm}$ at the surface and $6.8 \mathrm{ppm}$ in subsurface samples. Surface soil collected at twenty scattered locations on the Hanford site ranged 


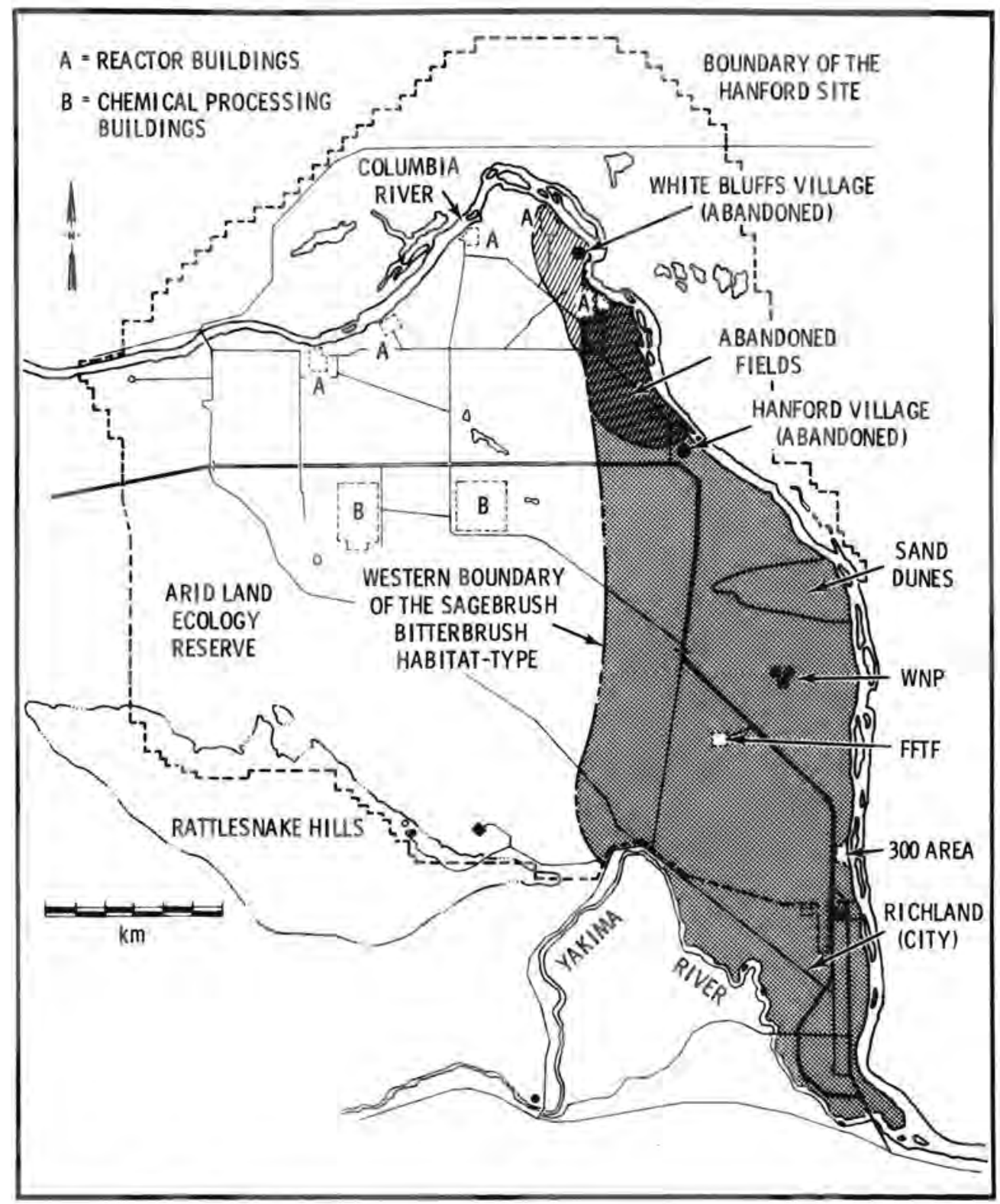

FICURE 2. Map Showing the Extent of the Bitterbrush-Sagebrush Community on the U.S. Department of Energy's Hanford Site in Southcentral Washington

between 0.12 and $0.76 \mathrm{ppm}$ Collectively, these data indicate that 127 I content of soil at the Hanford site is substantially less than the world-wide average for soil, i.e., 5 ppm.

The 127 I content of jackrabbit thyroid glands collected at monthly intervals in the 1950 s showed pronounced seasonal fluctuations. July was the month of maximal iodine concentration and March was the lowest (Table 2). The biological factors responsible for the observed fluctuations in $127_{1}$ content are not clear.
An endogenous physiological rhythm may be correlated with seasonal temperature regimes, solar radiation and the phenology of forage plants. July is usually the hottest month of the year and forage plants are desiccated. Day-time air temperatures of ten exceed $100^{\circ} \mathrm{F}$ and even higher temperatures occur at the soil surface. It seems likely that the summer season is a stressful time of the year for jackrabbits, because daytime air temperatures are high and succulent forage (to provide water) is lacking. 
TABLE 1. Stable lodine, ${ }^{127}$, and Radioactive lodine, ${ }^{129}$, in Cheatgrass and Soil from Two Places on the Hanford NERP

\begin{tabular}{|c|c|c|c|c|}
\hline \multirow[b]{2}{*}{ Sample Size } & \multicolumn{2}{|c|}{$1000 \mathrm{ft}$ Elevation } & \multicolumn{2}{|c|}{$1750 \mathrm{ft}$ Elevation } \\
\hline & $\begin{array}{r}127 \mathrm{I} \\
\mu \mathrm{g} / \mathrm{g} \\
\end{array}$ & $\begin{array}{r}129 \mid, \\
\mathrm{fCi} / \mathrm{g} \\
\end{array}$ & $\begin{array}{c}127 \mathrm{l}, \\
\mu \mathrm{g} / \mathrm{g}\end{array}$ & $\begin{array}{l}1291, \\
\mathrm{fCi} / \mathrm{g} \\
\end{array}$ \\
\hline Cheatgrass & 0.36 & 2.9 & 0.36 & 1.9 \\
\hline Surface soil $(2.5 \mathrm{~cm})$ & 0.52 & 3.3 & 0.60 & 2.1 \\
\hline Subsoil $(15 \mathrm{~cm})$ & 0.41 & 0.058 & 0.72 & 0.045 \\
\hline Subsoil $(60 \mathrm{~cm})$ & 1.30 & 0.019 & 2.70 & 0.005 \\
\hline
\end{tabular}

TABLE 2. Stable lodine Content of Jackrabbit Thyroid Glands Collected on the Hanford NERP. Measurements in $\mathrm{mg} / \mathrm{g}$ dry weight

\begin{tabular}{|c|c|c|c|c|c|c|}
\hline Month & 1956 & 1957 & 1958 & 1959 & 1960 & Avg. \\
\hline July & 0.48 & 0.48 & 1.0 & 0.58 & 0.62 & 0.63 \\
\hline March & 0.22 & 0.20 & 0.16 & 0.22 & 0.24 & 0.21 \\
\hline
\end{tabular}

Spring is probably the most favorable season, as moderate air temperatures prevail. The many plant species of the sagebrush-grass community are actively growing. The spring flush of growth is not only succulent but nutritious (high protein). Increased concentrations of iodine in jackrabbit thyroids in summer may be a response to the most stressful season of the year. However, seasonal fluctuations in iodine content of thyroids of pen-fed domestic sheep have also been observed, suggesting that endogenous physiological rhythms, associated with the breeding cycle, affect the 127 I content of mammalian thyroid glands. Only a few mule deer thyroids have been analyzed for 127 I content. Values ranging between 0.25 and

$28 \mathrm{mg} 127$ I per gram fresh weight were measured in the 1950s. Values ranging between 14 and $22 \mathrm{mg} 127$ I per gram fresh weight and averaging 19 were measured in 1980 . The $127_{I}$ content of thyroids was much higher in mule deer than in jackrabbits. It is not known if the 127 I content of mule deer thyroids shows a seasonal pattern such as that exhibited by wild jackrabbits and domestic sheep, because seasonal sampling of deer on the Hanford site has not been performed.

The 127 I content of dozens of thyroid glands of white-tailed deer (Odocoileus virginianus) collected in Missouri averaged $1.0 \mathrm{mg} / \mathrm{g}$ fresh weight, a value much lower than Hanford mule deer. Mule deer collected from the Blue Moun- tain and Cascade Mountain regions of Washington and Oregon also had lower contents of $127_{\text {I }}$ than did Hanford deer. These data indicate that the $127_{\text {I content of mule deer thyroids }}$ from Hanford is high, but the factors responsible for this observed phenomena are unresolved since plant and soil contents of iodine are relatively low as compared to other regions.

In the early years of chemical fuel reprocessing on the Hanford site (1940s to 1950s), wild animals were used as indicators of the direction and distance of dispersal of radioactive $131_{1}$ released into the air from industrial stacks. Iodine-131 levels in jackrabbit thyroids fluctuated from month to month, but the highest concentrations usually occurred in the winter months and the lowest concentrations in the summer months. This was in contrast to non-radioactive iodine, which showed the highest concentrations in summer. Iodine-131 was mostly on the outside of plant leaves and retained on the leaves following deposition from the air. The short half-time, $\sim 8$ days, precludes $131_{\text {I from part ic ipating }}$ in long-term ecological mineral cycling.

Iodine-129 is a naturally occurring radionuclide. It is produced in nature by spontaneous fusion of uranium and thorium and by interactions of cosmic radiation with xenon and tellurium. However, some of the man-induced sources of $129_{1}$ are nuclear explosions and nuclear fuel reprocessing facilities. Because of its long half-time, ${ }^{129}$ I can be expected to persist in the soil and participate in ecological mineral cycling. The thyroids of Hanford deer had greater concentrations of $129_{I}$ than deer thyroids collected beyond the boundaries of the Hanford NERP. The elevated levels of $129_{\text {I }}$ in thyroids probably originated at the chemical separations facilities at Hanford. The data are not absolute, however, because preoperational background values for 129 I were not obtained before the startup of the Hanford nuclear facilities. In this case, the contribution of natural 129 I is not separable from the man-induced contribution.

Surface soil samples collected at scattered locations around the Hanford site showed that samples collected close to the separation $\mathrm{fa}-$ cilities had the highest ${ }^{129}$ I levels, indicating that the source of $129_{\text {I was the chemical }}$ separation facilities at Hanford (Table 3 ).

After a long history of industrial use, the Hanford site shows enhanced levels of $129_{1}$ in soil, forage plants, and in the thyroid glands of deer living on the Hanford site. The amounts of $129_{I}$ in deer thyroids is believed to be too small to produce histological damage. 
TABLE 3. Iodine-129 Content of Surface Soils Collected at Various Distances from the Chemical Separations Facilities on the Hanford Site. Measurements in $\mathrm{fCi} / \mathrm{g}$.

\begin{tabular}{|c|c|c|c|}
\hline & Chemic & $\begin{array}{l}\text { istance fro } \\
\text { Separation }\end{array}$ & Facilities \\
\hline & $\begin{array}{l}\text { Zone l, } \\
>2 \mathrm{~km}\end{array}$ & $\begin{array}{l}\text { Zone II, } \\
10-20 \mathrm{~km}\end{array}$ & $\begin{array}{l}\text { Zone III, } \\
32-42 \mathrm{~km}\end{array}$ \\
\hline Average value & 13 & 1.6 & 1.7 \\
\hline Range of values & $3-22$ & $0.14-2.9$ & $0.28-4.0$ \\
\hline Number of samples & 7 & 8 & 5 \\
\hline
\end{tabular}

It is measurable only bec ause of the extremely low detection limits of sophisticated radiation detecting instrumentation and chemical separation techniques.

\section{HANFORD WILDLIFE STUDIES(a)}

A yearly census of nesting Canada geese, Branta canadensis, has been conducted on islands in the Hanford Reach of the Columbia River since 1953. In the early years, 19531963, Island 6 was a favored nesting is land (Figure 3). However, in the 1970s, the island was rejected as a nesting habitat. The primary reason for the avoidance of Island 6 is the year-round presence of coyotes, Canis latrans, on the 150-hectare island. In 1978, the Washington State Game Department commenced a coyote suppression operation focused on the islands and adjacent Columbia River shoreline. The coyote suppression activity so far has not restored Island 6 as a favorable goose nesting site. Coyotes still occupy the island on a year-round basis, as evidenced by many tracks and occasional sightings.

Two favored nesting islands in the upper reach, Islands 1 and 2, showed different responses to the coyote suppression. The number of goose nests has increased on Island 1 and decreased on Is land 2 (Figure 3). Nest establishment on Islands 11 and 12 located in the middle reach showed erratic behavior. In the lower reaches of the river near the city of Richland, Islands 18 and 19 showed increases in goose nests while Islands 17 and 20 showed relatively little change (Figure 3 ). The dramatic drop in the number of goose nests

(a) This study was funded by the Service Assessment Program (Richland Operations office).
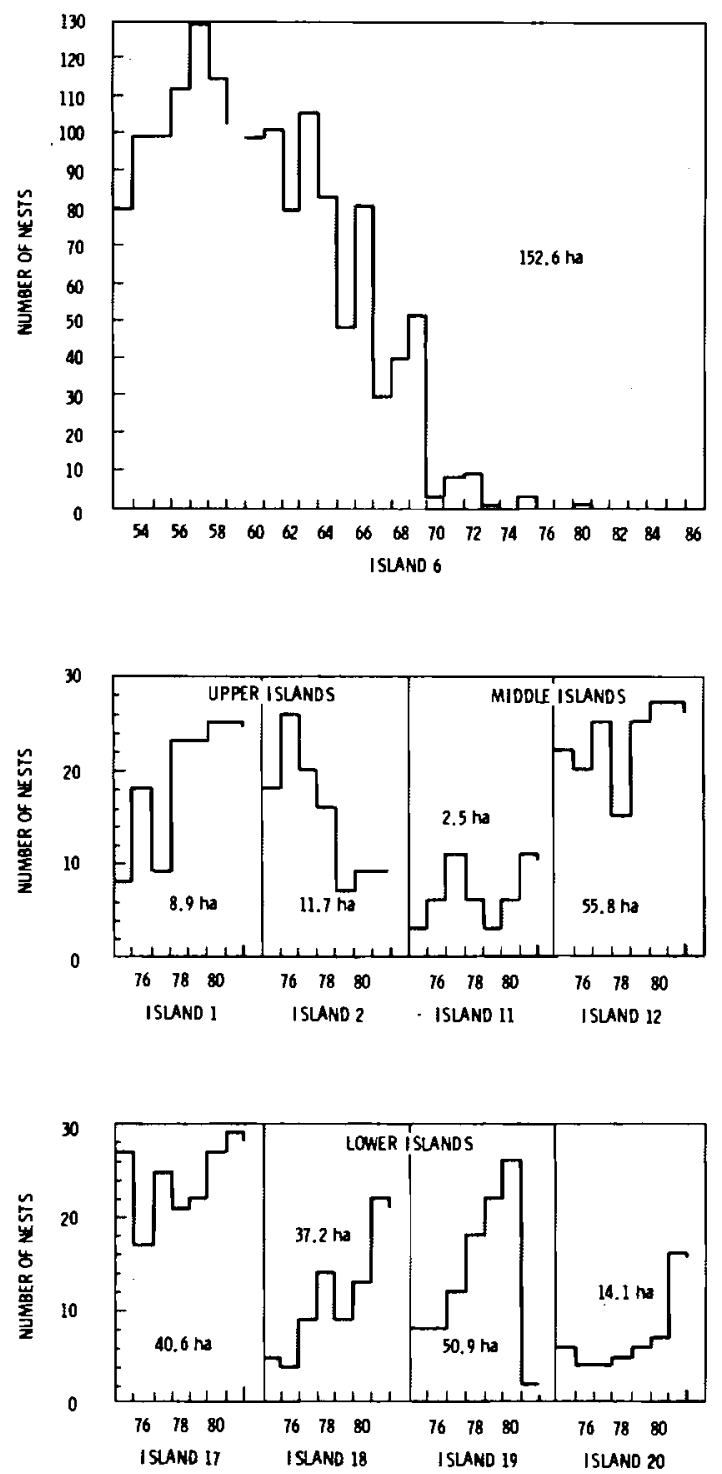

FIGURE 3. Number of Goose Nests on Selected Islands During the Years 1953 to 1981

on Island 19 in 1981 is believed to be caused by the presence of domestic dogs on the islands immediately before the goose nesting season.

Land use along the Hanford Reach of the Columbia is under at least four different kinds of management. The land along the western shore is under the management of the U.S. Department of Energy for energy research and development. 
The eastern shore is managed by the U.S. Department of Interior, Fish and Wildlife Service as a wildlife refuge. 0ther areas are managed by the Washington State Game Department for outdoor recreation, hunting, and fishing. Some land is also under private management, mostly for irrigated agriculture. Canada goose and coyote populations regularly use lands under all kinds of land management. The continued existence of nesting geese along the Hanford Reach is clearly in the hands of the cognizant land managers and the agencies involved in the use of the Columbia River itself.

The yearly counting of chinook salmon redds in the Hanford Reach of the Columbia River has been conducted since 1947 (from Richland, Washington, upstream to Priest Rapids Dam). Counts were made in the autumn months of October and November on days with reasonable visibility and flying conditions. The maximum number of redds counted in 1980 was 1487 on November 4 . The number of redds observed is believed to be somewhat below the actual numbers because poor weather hampered visibility during the flights. Nevertheless the Hanford Reach remains an important spawning area for fall chinook salmon in the mid-Columbia river. The continued existence of spawning salmon in the Hanford Reach depends upon the maintenance of the Columbia as an unimpounded, freeflowing stream.

The annual census of wintering bald eagles on the Hanford Reach of the Columbia was conducted in December 1980 and January and February 1981. The census was done by visual sightings from an airplane. The maximum number of bald eagles counted was 20 . This is the same as in 1980. The continued use of the Hanford Reach of the Columbia by wintering bald eagles, a threatened species, depends upon the presence of salmon carcasses as a readily available food source and the presence of a few large trees suitable as night roosts and also freedom from harassment by human activities.

During the spring nesting season, adult herons hunt for fish in the backwaters and sloughs of the Hanford Reach of the Columbia River. Fish are brought back to the nest to feed the young birds. By analyzing the debris cast from the nests each year, some idea of the amount and kinds of trace elements and radionuclides present in the food chains of a high-trophiclevel bird is obtained.

Information is not available at this time that establishes the maximum distance that parent birds can travel from their nests in search of food. Small radiotransmitters attached to adult birds offer a way to monitor the foraging movements of these strong-flying birds, which have unrestricted access to industrial ponds located in waste management zones in the interior of the Hanford site.

\section{GRADUATE STUDENT RESEARCH}

Two students enrolled at Washington State University, Pullman, Washington, conducted research projects for advanced degrees in zoology on the Hanford NERP.

The research conducted by $P$. A. Thompson is designed to obtain new information concerning habitat requirements of marsh hawk (Circus cyaneus) populations. Spec if ic objectives of the research are to: 1) enumerate marsh hawk productivity in different study areas representing different habitat types; 2) determine if wintering populations are the same as the breeding populations; and 3) delineate foraging ranges. Hypotheses that hawks will use habitats according to availability and that the more "typical" habitat types will generate higher productivity will be tested.

Three areas were selected for study. The ALE Reserve, the Washington State Game Department Wildlife Recreation Area, and the 200-Area Plateau are study areas that represent different habitats and different levels of human activity.

In 1981, 20 occupied nests were located; 7 were on ALE, 9 on the Game Department area, and 4 on the 200-Area Plateau. Radiotelemetry was used to follow the movements of adult hawks. Apparently, this is the first instance in which radiotransmitters have been used to follow the flight movements of marsh hawks. The discovery that marsh hawks use the dry habitats on the ALE site as nesting locations indicates that pond/marsh habitat may not be as necessary for marsh hawk reproduction as often inferred from field observations.

The other research topic, completed by $B . K$. Dewaard in June 1981, concerns Canada geese, Branta canadensis moffitti, nesting on Columbia River islands. The purpose of this study was to analyze the numbers of nesting geese with respect to habitat changes that have occurred by damming the Columbia River, thus resulting in fluctuating river flows. Changed river flows have altered the vegetational cover on certain islands. Other factors considered in the analysis were predation by coyotes, Canis latrans, and the opening of river islands to public access after two decades of restricted access. 
Peak numbers of Canada geese nests were observed in 1958. Since 1959, however [the year Priest Rapids Dam (upstream) started generating electricity], the number of nests has erratically declined. Although 20 islands were used as nesting locations in the years 1953 to 1969 , 95\% of the nesting geese since 1970 have used only 10 of these islands. Opening of the islands to public use has apparently not been important in the overall decline in the numbers of nesting geese. Islands loc ated close to the city of Richland have shown increases in nesting populations in recent years. The possibility of two subpopulations of Canada geese breeding on the Hanford Reach of the Columbia River was examined.

\section{UPTAKE OF TRACE ELEMENTS BY SAGEBRUSH FROM EXPERIMENTALLY TREATED SOIL}

Sagebrush, Artemisia tridentata, is an abundant shrub on undeveloped lands in the semiarid regions of the northwestern United States. It is not palatable to livestock and is held in low esteem by livestock growers. Wildlife managers regard sagebrush more favorably. Sagebrush serves as forage for sagegrouse, antelope, jackrabbits and mule deer and also as a nesting habitat for sage sparrows. Because of its wide geographic range and abundance, sagebrush can be used as a biological monitor of the dispersal of airborne chemicals produced by industrial facilities, i.e., coal-fired steam-electric plants and nuclear fuel reprocessing plants. However, because of its low economic value, sagebrush has seldom been used as an experimental species in soil-plant uptake studies.

The purpose of this investigation was to determine if trace elements experimentally added to surface soil beneath the canopy-spread of mature field-living sagebrush plants could be detected by collecting and chemically analyzing leaf tissues.

The trace elements boron, copper, manganese, molybdenum and zinc were added to the surface soil beneath individual sagebrush plants in three different concentrations: $0.0,0.5,5$, 20 grams of borate, cuprous chloride, manganous chloride, molybdenum trioxide and zinc chloride.

The soil was experimentally treated in the summer of 1978. In May 1981, new leaves were hand picked from individual shrubs, dried, dissolved in nitric acid and chemically analyzed using inductive coupled plasma spectroscopy.

The results are summarized in Figure 4. Boron, copper, manganese and zinc were not
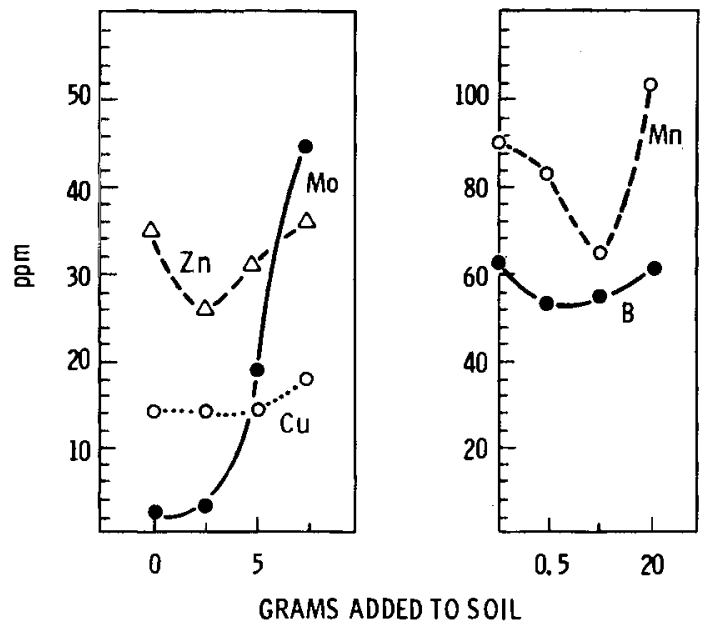

FIGURE 4. Concentration of Manganese, Boron, Zinc, Copper and Molybdenum in Sagebrush Leaves

taken up by sagebrush leaves in significant amounts in any of the experimental treatments. The data indicate, however, that molybdenum was taken up by the sagebrush leaves. The highest average concentrations, $45 \mathrm{ppm}$, were from the plants receiving the most molybdenum. These plants had 20 times more molybdenum than the control plants. Other kinds of trace elements, e.g., cadmium, lead, nickel, selenium and others, could be tested in the same way.

On August 13, 1981, a wildfire burned through the study area. Although the study was originally designed to last for ten or more years, the fire abruptly terminated the experiment.

CATION CONTENT OF THE LEAVES OF DESERT SHRUBS AND ITS RELATIONSHIP TO TAXONOMIC AND ECOLOGIC CLASSIFICATION

Field studies of cation uptake by wild plants are bounded by uncertainties as to whether the cation content of leaves as measured by field sampling is determined mostly by life processes or by the chemical and physical properties of the rooting substrate. In the absence of experimental data, field data are usually interpreted using statistical analyses. Analysis of variance and cluster analyses were used to help interpret a data set of cation contents of leaves collected from the Nevada Test Site, Nevada. A Fisher's protected least significant difference test was used to determine differences among mean values among seven selected shrub taxa. A clustering analysis (Biomedical Computer Program: P series, 1979) was used to demonstrate linkages between sodium, potassium, calcium and magnesium content of leaves of seven taxa. 
Another data set that measured the cation content of desert shrub leaves collected from the southern part of the intermountain region region and data from the northern part of the region (Hanford site and INEL), were also examined to obtain some insight as to the geographic variation of cation content of leaves of the most wide-ranging taxa.

The leaf collection from Rock Valley, Nevada, was of interest because it represented shrubs of different taxa growing in a mixed stand and rooted in a common substrate (Table 4). Cation contents of leaves were log-transformed to reduce heterogeneity of the variance. There were significant $(\alpha=0.05)$ differences between taxa with respect to cation content. A Fishers' protected least significant difference test was used to determine which cation values (potassium, sodium, calcium, magnesium) were different from the others. These analyses showed that Krameria, Larrea, Lycium andersoni $i$ and Lycium pallidum were not significantly different in potassium values from each other but were different as a group from Ceratoides, Ambrosia and Grayia. Ceratoides and Krameria accumulated small amounts of sodium, and L. pallidum and L. andersoni $i$ accumulated reTatively large amounts.

Ambrosia, Larrea and Grayia had intermediate sodium values. Lycium palTidum and $L$. andersonii were relatively high in calcium and Larrea and Ceratoides were relatively low. Grayia, Abrosia and Krameria were intermediate in calcium. Lycium palTidum and Grayia were high in magnesium. Larrea was low. Other species were intermediate. These data indicate that different shrub taxa rooted in a common substrate have some ability to selectively accumulate cations.
A cluster analysis was used to determine similarities in cation content of the leaves from the Rock Valley collection. The analysis used the mean concentration of cations for each species (Table 4). Cation concentrations were standardized to $z$ scores and averages were weighted by sample size ( $n=3$ to 7). The clustering algorithm involved average linkage and was based on Euclidean distance. The first cluster pair links Ambrosia (Compositae) with Ceratoides (Chenopodiaceae) (Figure 5). The second cluster pair links Larrea (Zygophyllaceae) with Krameria (Krameriaceae). Clusters 1 and 2 were amalgamated and the third cluster linked with Grayia (Chenopodiaceae). The final cluster linked the two Lycium taxa. These analyses show that Grayia spinosa is not very closely linked with Ceratoides in terms of cation content, even though these shrubs are taxonomically assigned to the same family.

The cation content of leaves collected from desert shrub taxa at widely separated locations is summarized in Figure 6 . Taxa in the Chenopodiaceae and the Solanaceae were higher in total cation content than the taxa in the Compositae, Zygophyllaceae and Rosaceae. Ceratoides lanata was lower in total cation content than the other Chenopods. Two kinds of cation absorption mechanisms were observed in the Chenopodiaceae. One $k$ ind is represented by Ceratoides lanata, Grayia spinosa and Atriplex canescens. These plants accumulate potassium and onty small amounts of sodium. The second kind of cation accumulation is sodium accumulation as represented by Kochia americana, Atrip lex hymenelytra, Atriplex confertifolia, Sarcobatus vermiculatus and Atriplex polycarpa. In this latter group, sodium content of leaves ranged between $21 \%$

TABLE 4. Average Concentrations of Cations (\% dry wt. except $\mathrm{Na}$ as ppm) from Seven Plant Taxa Growing in the Same Community, Rock Valley, Nevada. Values joined by a common line are not significantly different.

K

\begin{tabular}{ll}
\hline Krpa & 1.56 \\
Latr & 1.86 \\
Lyan & 1.95 \\
Lypa & 1.96 \\
Cela & 2.57 \\
Amdu & 3.02 \\
Grsp & 3.09
\end{tabular}

\begin{tabular}{lr}
\multicolumn{2}{c}{$\mathrm{Na}$} \\
\hline Cela & 115 \\
Krpa & 155 \\
Amdu & 375 \\
Latr & 497 \\
Grsp & 734 \\
Lyan & 2728 \\
Lypa & 5533
\end{tabular}

Lypa

\begin{tabular}{ll}
\multicolumn{2}{c}{ Ca } \\
\hline Latr & 1.28 \\
Cela & 1.30 \\
Grsp & 2.32 \\
Amdu & 2.46 \\
Krpa & 2.76 \\
Lypa & 4.21 \\
Lyan & 5.50
\end{tabular}

Krpa $=$ Krameria parvifolia, Latr $=$ Larrea tridentate, Lyan $=$ Lycium andersonii, Lypa $=$ Lycium pallidum, Cela = Ceratoides lanata, Amdu = Ambrosia dumosa, Grsp $=$ Grayia spinosa.

\begin{tabular}{|c|c|}
\hline & $\mathrm{Mg}$ \\
\hline Latr & 0.20 \\
\hline Krpa & 0.39 \\
\hline Cela & 0.40 \\
\hline Amdu & 0.46 \\
\hline Lyan & 0.85 \\
\hline Lypa & 1.21 \\
\hline Grsp & 1.28 \\
\hline
\end{tabular}




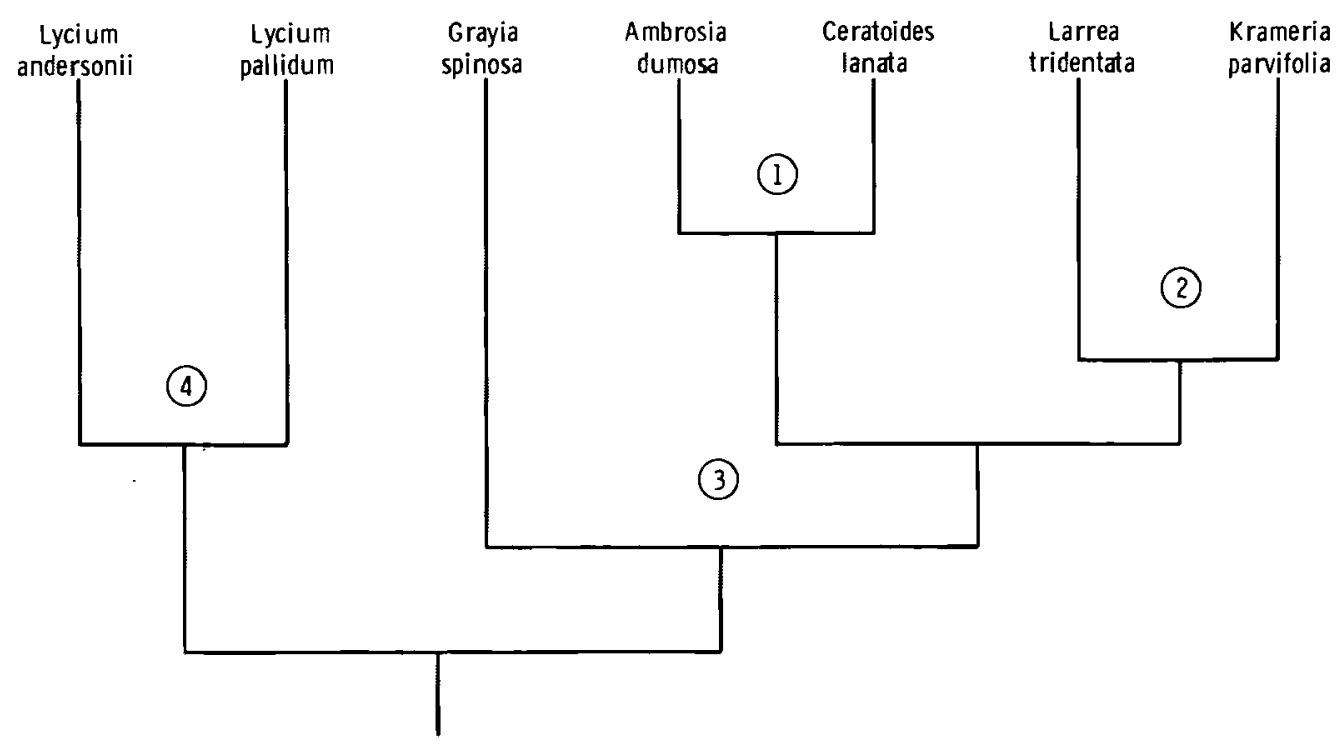

FIGURE 5. Grouping of Desert Shrub Species According to Cation Content of Their Leaves

and $83 \%$ of total cations. Atriplex polycarpa and Sarcobatus vermiculatus were the most extreme sodium accumulators. The family Solanaceae also showed some ability to accumulate sodium. Lycium pallidum accumulated sodium at $21 \%$ of the total cation content. Lycium andersoni $i$ and L. pallidum both accumulated more calcium than the other taxa. This suggests that different cation uptake and retention processes are present in the Solanaceae as compared to the Chenopodiaceae and the other families.

Artemisia tridentata (Compositae), Larrea tridentata (zygophyllaceae) and Coleogyne ramosissima (Rosaceae) were at the low end of the scale of total cation content, but Ambrosia dumosa (Compositae) had a relatively high total cation content of $8.6 \%$. None of the taxa in these families accumulated sodium to the extent of the taxa in the Solanaceae and Chenopodiaceae.

Grayia spinosa and Sarcobatus vermiculatus in Washington had higher total cation contents than Artemisia tridentata and Purshia tridentata. Sarcobatus accumulated sodium and Grayia accumulated potassium. The leaves of Purshia tridentata and Artemisia tridentata had relatively high amounts of calcium.

Grayia spinosa and Sarcobatus vermiculatus in Idaho had higher total cation contents than Artemisia tridentata and Purshia tridentata. However, Grayia had higher amounts of calcium than either Artemisia or Purshia.
A listing of eleven shrub taxa (Table 5) is arranged into three groups. The classification in the first column is based on the seasonal availability of soil water in the rooting zone. Ten of the taxa are classified as xerophytes and one is classified as a phreatophyte, i.e., Sarcobatus. Phreatophytes obtain growth water from a supplemental source other than direct downward percolation of rainfall into the ground. The second column classifies these same eleven taxa according to their capacity to accumulate cations in their leaves. Six taxa are glycophytes and are not cation accumulators. Five other taxa are cation accumulators, i.e., halophytes. The third column combines the availability of soil water with the plant capacity to accumulate cations. Six taxa listed as xerophytes accumulate cations in small quantities. Four taxa accumulate cations and are classified as xerohalophytes. Sarcobatus is 1 isted as an osmophyte. Osmophytes accumulate cations, mostly sodium in their leaves, and have root access to water in excess of that of seasonal rainfall and probably use sodium as an osmoregulatory mechanism.

Desert shrub taxa have received more attention in recent years than in the past because of their potential usefulness in revegetating disturbed ground, such as the kinds of massive disturbance created by surface mining and oil shale processing in arid and semi-arid regions. 


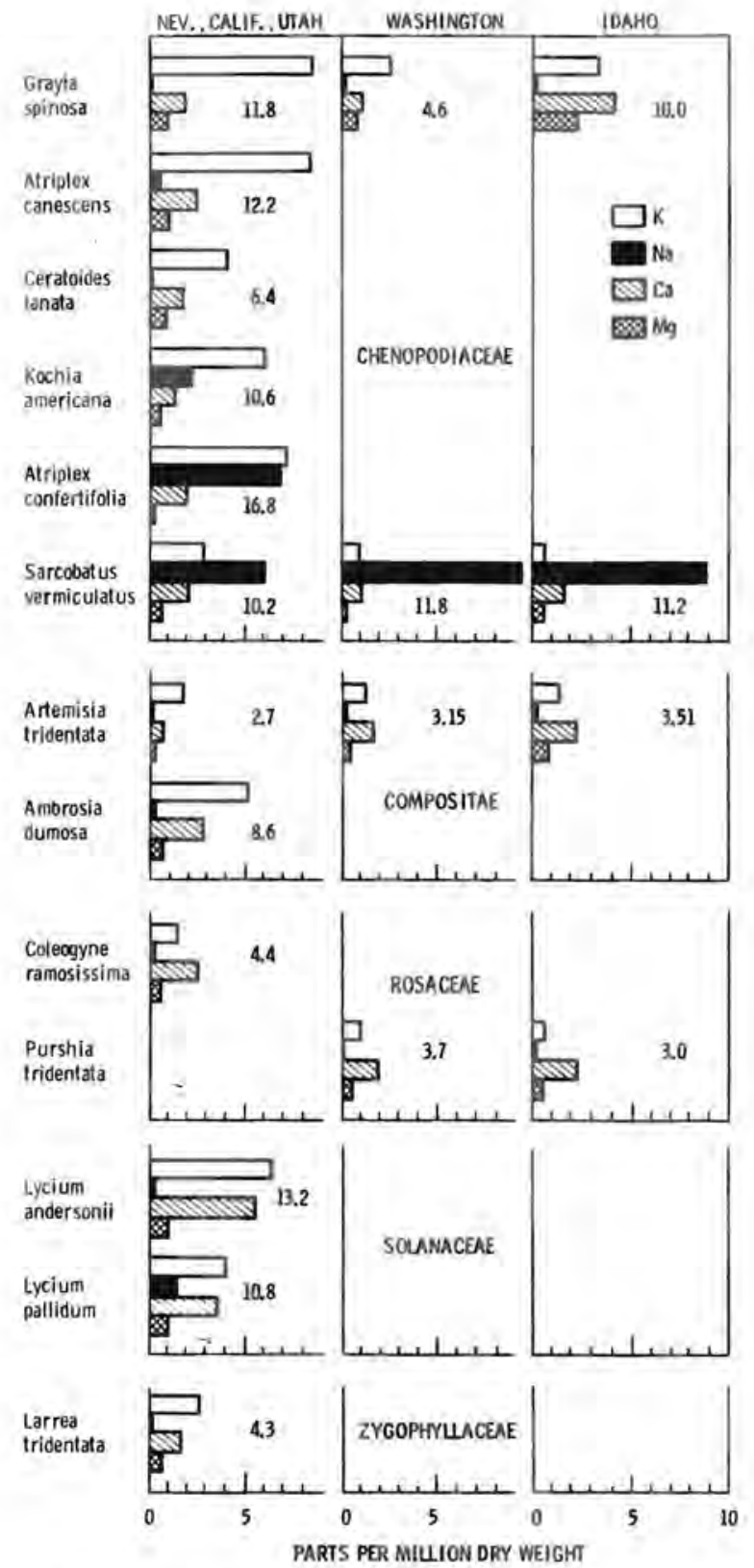

FIGURE 6. Cation Content of Leaves of Desert Shrubs Collected at Various Places in the Western United States
TABLE 5. Grouping of 11 Representative Desert Shrub Taxa by Cation Content and Water Availability

III

\begin{tabular}{|c|c|c|}
\hline $\begin{array}{l}\text { I } \\
\text { Soil Water }\end{array}$ & $\begin{array}{c}\text { II } \\
\text { Cation Content } \\
\end{array}$ & $\begin{array}{c}\text { Cation Content \& } \\
\text { Soil Water } \\
\end{array}$ \\
\hline Xerophytes & Halophyles & Osmophytes \\
\hline $\begin{array}{l}\text { Larrea } \\
\text { tridentata }\end{array}$ & $\begin{array}{l}\text { Sarcobatus } \\
\text { vermiculatus }\end{array}$ & $\begin{array}{l}\text { Sarcobatus } \\
\text { vermiculatus }\end{array}$ \\
\hline Artemisia & Grayia spinosa & \\
\hline tride & Atriplex & Xerohalophytes \\
\hline $\begin{array}{l}\text { Ceratoides } \\
\text { lanata }\end{array}$ & $\begin{array}{l}\text { confertifolia } \\
\text { A. canescens }\end{array}$ & $\begin{array}{l}\text { Atriplex } \\
\text { confertifolia }\end{array}$ \\
\hline $\begin{array}{l}\text { Purshia } \\
\text { tridentata }\end{array}$ & $\begin{array}{l}\text { Lycium } \\
\text { pallidum }\end{array}$ & $\begin{array}{l}\text { A. canescens } \\
\text { Lycium pallidum }\end{array}$ \\
\hline $\begin{array}{l}\text { Ambrosia } \\
\text { dumosa }\end{array}$ & Glycophytes & Grayia spinosa \\
\hline $\begin{array}{l}\text { Atriplex } \\
\text { confertifolia }\end{array}$ & Larrea tridentata & Xerophytes \\
\hline $\begin{array}{l}\text { Coleogyne } \\
\text { ramosissima }\end{array}$ & $\begin{array}{l}\text { Artemisia } \\
\text { tridentata }\end{array}$ & $\begin{array}{l}\text { Larrea tridentata } \\
\text { Ambrosia }\end{array}$ \\
\hline $\begin{array}{l}\text { Grayia } \\
\text { spinosa }\end{array}$ & $\begin{array}{l}\text { Ambrosia } \\
\text { dumosa }\end{array}$ & $\begin{array}{l}\text { dumosa } \\
\text { Purshia }\end{array}$ \\
\hline $\begin{array}{l}\text { Lycium } \\
\text { pallidum }\end{array}$ & $\begin{array}{l}\text { Purshia } \\
\text { tridentata }\end{array}$ & $\begin{array}{l}\text { tridentata } \\
\text { Coleogyne }\end{array}$ \\
\hline Phreatophytes & $\begin{array}{l}\text { Coleogyne } \\
\text { ramosissima }\end{array}$ & $\begin{array}{l}\text { ramosissima } \\
\text { Ceratoides lanata }\end{array}$ \\
\hline $\begin{array}{l}\text { Sarcobatus } \\
\text { vermiculatus }\end{array}$ & $\begin{array}{l}\text { Ceratoides } \\
\text { lanata }\end{array}$ & $\begin{array}{l}\text { Artemisia } \\
\text { tridentata }\end{array}$ \\
\hline
\end{tabular}




\section{- Terrestrial Ecology}

Principal Investigator: L. E. Rogers

Associate Investigators: R. E. Fitzner, K. A. Gano, J. L. Warren, M. C. McShane and R. H. Sauer

The Terrestrial Ecology Studies are centered on the Hanford Arid Lands Ecology Reserve and support long-term basic ecological studies designed to ensure a strong theoretical base for decision-making policies, environmental assessments and resource management decisions involving industrial facilities and burial sites. Results are intended to apply not only to Hanford lands but to lands throughout the semi-arid regions of the western United States.

\section{EFFECTS OF FIRE AND CLIPPING ON BLUEBUNCH WHEATGRASS}

Bluebunch wheatgrass (Agropyron spicatum) is the major perennial bunchgrass on the ALE Reserve. The effect of dead foliage through wildfire or grazing is not clearly understood even though fire and grazing are the most common perturbations for these communities.
Study plants were burned or clipped either individually or as part of a $1-m$ radius circle to simulate differences caused by competition from surrounding vegetation. Plant response was measured in terms of productivity, leaf lengths, culm lengths, seed head lengths, basal area and the number of flowering culms. Results are shown in Figure 1 .
A. Diameter Difference $(\mathrm{cm})$

\begin{tabular}{|c|c|c|}
\hline & Mean & S. E. \\
\hline Contròl & 1.52 & 0.33 \\
\hline Clip Area & 1.05 & 0.14 \\
\hline Clip Plant & 0.88 & 0.25 \\
\hline Burn Area & 0.63 & 0.21 \\
\hline Burn Plant & -0.17 & 0.29 \\
\hline
\end{tabular}

D. Flowering Culm Length $(\mathrm{cm})$

\begin{tabular}{|c|c|c|}
\hline & Mean & S. E. \\
\hline Burn Area & 31.48 & 4.86 \\
\hline Control & 30.28 & 4.13 \\
\hline Burn Plant & 28.58 & 4.15 \\
\hline Clip Plant & 21.59 & 3.80 \\
\hline Clip Area & 13.54 & 3.07 \\
\hline
\end{tabular}

B. Biomass (gm)

\begin{tabular}{|c|c|c|}
\hline & Mean & S. E. \\
\hline Control & 20.84 & 3.97 \\
\hline Burn Area & 15.31 & 1.77 \\
\hline Burn Plant & 14.12 & 2.17 \\
\hline Clip Plant & 13.77 & 2.33 \\
\hline Clip Area & 10.30 & 0.80 \\
\hline \multicolumn{3}{|c|}{ LSD Value $=6.7371$} \\
\hline
\end{tabular}

E. Seedhead Length $(\mathrm{cm})$

\begin{tabular}{|c|c|c|}
\hline & Mean & S. E. \\
\hline Burn Area & 4.87 & 0.79 \\
\hline Control & 4.37 & 0.76 \\
\hline Burn Plant & 4.19 & 0.62 \\
\hline Clip Plant & 3.13 & 0.53 \\
\hline Clip Area & 2.07 & 0.49 \\
\hline
\end{tabular}

\begin{tabular}{|c|c|c|}
\hline \multicolumn{3}{|c|}{ C. Leaf Length $(\mathrm{cm})$} \\
\hline & Mean & S. E. \\
\hline Control & 30.74 & 1.32 \\
\hline Clip Plant & 25.72 & 1.02 \\
\hline Burn Area & 25.51 & 1.25 \\
\hline Burn Plant & 25.18 & 0.96 \\
\hline Clip Area & 23.71 & 0.65 \\
\hline LSD & Value $=$ & \\
\hline
\end{tabular}

F. Number of Flowering Culms

\begin{tabular}{lcc}
\hline & Mean & S. E. \\
\cline { 2 - 3 } Control & 37.20 & \\
Clip Plant & 19.90 & \\
Burn Area & 13.00 & 5.97 \\
Clip Area & 12.15 & 4.41 \\
Burn Plant & 10.70 & 4.27 \\
\multicolumn{1}{c}{ MSE for 80 d.f. $=1050.70$}
\end{tabular}

(a) When only the study plant was treated, the word "plant" follows the specific treatment. For treatment involving the study plant and surrounding vegetation with $1 \mathrm{~m}$, the word "area" follows the specific treatment. The lines pair treatments that are not significantly different as determined by an LSD test. There are 20 plants in each treatment $(n=20)$. S.E. $=$ standard error, $M S E=$ mean square error, d.f. $=$ degree of freedom.

FIGURE 1. Treatment Effects on Mean Diameter Difference, Biomass, Leaf Length, Flowering Culm Length and Seedhead Length(a) 
The average post-treatment basal area of clipped plants was not significantly different from that of controls. Compared to controls, the clump diameter of burned plants was significantly reduced $50 \%$ to $111 \%$, depending upon the area of treatment application. Burning a plant as part of an area did not significantly affect diameter when compared to any of the clipped plants. Burning a single plant, however, caused a reduction in diameter that was significant when compared to any other treatments (Figure la).

Burned plants did not have a biomass significantly different from the controls. Clipping, however, significantly affected biomass. Compared to controls, the biomass of clipped plants was reduced by $42 \%$. There were no significant differences in biomass when burned plants were compared to clipped plants (Figure 1b).

Clipping and burning had a significant effect on leaf length. When compared to controls, the average leaf length of clipped plants was reduced by 20\%: Burning decreased plant leaf length by $18 \%$. When clipped plants were compared to burned plants, regardless of area of treatment application, there was no significant difference in leaf length (Figure $1 \mathrm{C}$ ).

The average culm length of plants burned as part of an area was slightly, though not significantly, higher than that of controls. Culms of plants clipped as part of an area were significantly shorter than those of controls (by $55 \%$ ) and burned plants. There was no significant difference in culm length between controls, any of the burned plants, or single clipped plants (Figure ld).

Burning a plant as part of an area increased seedhead length by $11 \%$ when compared to controls. This amount is, however, insignificant. There was no significant difference in average seehead length between controls, any burned plants, or single clipped plants. Plants clipped as part of an area had seedheads significantly shorter than those of controls (by 53\%) and burned plants (Figure le). No significant differences were found between the control and treated plants for number of flowering culms (Figure 1f).

Results from this study suggest that burning or light grazing a bluebunch wheatgrass range, after the plants have cured, would decrease vegetative, but not reproductive, productivity the following season. Heavy grazing, even in late season, would certainly decrease the vigor of a bluebunch wheatgrass range.
BIRDS OF PRISTINE AND OLD-FIELD COMMUNITIES ON THE ALE RESERVE

Bird surveys were conducted on paired study areas representing both pristine and oldfield plant communities on the Arid Lands Ecology Reserve from October 1978 through May of 1980. The two pristine communities were climax habitats of bluebunch wheatgrass and sagebrush. The old fields were cultivated over 40 years ago and today are dominated by cheatgrass.

Twenty-one species of birds were observed during the study. The pristine communities accounted for over $75 \%$ of the species recorded. Sage sparrows, vesper sparrows, Savannah sparrows and Brewer's sparrows were almost completely associated with the pristine communities. Meadowlarks and chukar partridge associated with old-field communities during non-breeding periods; however, pristine communities were the preferred breeding areas.

This study is revealing that old-field communities do not support many native bird species. Pristine communities provide both food and cover necessary for year-round survival. Variations between diversity and density of bird species between the paired pristine sites indicates that microhabitat differences affect birds.

The native species of sparrows are clearly partitioned into microhabitats. This may result from vegetation structure and microclimatic variables. Planned future studies are intended to provide additional data on factors that affect the partitioning of the various species of sparrows.

COLONY DENSITY AND ACTIVITY OF THE ANT, CAMPONOTUS SEMITESTACEUS, IN A SHRUB-STEPPE COMMUNITY

The ant, Camponotus semitestaceus, is a large, conspicuous species (7 to $13 \mathrm{~mm})$ that has received little ecological attention. Previous studies have indicated that this species is largely nocturnal and $c$ an be abundant within shrub-dominated communities. The purpose of this task is to obtain a basic understanding of the ecological role of $C$. semitestaceus occupying shrub-steppe communities.

Activity patterns for this species were monitored by using a series of baited pitfall traps. A timing device was used to automatically open and close the traps. Six of these 
automatic traps were spaced evenly around known colony entrances. Each trap was opened for a 4-hour period. At the end of each 24-hour period, the number of ants captured was tallied. This provided an indication of the time of day when the ants actively foraged. From these data, and from direct observations, it appears that the ants do not forage during daylight hours. Direct observations made at night indicated that the ants became active shortly after sundown and remained active until first light. The pitfall trap data, however, did not indicate such an extended foraging time. Generally, ants were captured during only one of the nightly 4-hour sampling intervals.

A different method of documenting activity times will be employed next year. A $35 \mathrm{~mm}$ camera will be used to automatically photograph colony entrances at set intervals throughout the day and night. The number of ants around the colony entrance will provide an index of activity.

Colony density in the sagebrush bunchgrass community will be estimated using randomly selected plots within a 25-ha area. Ten randomly selected transects, each containing twenty $2-m^{2}$ plots, have been searched for colony entrances. These preliminary data will be used to determine the number of transects necessary to provide a reliable estimate of colony density.

COMPARISON OF SMALL-MAMMAL ABUNDANCE IN SHRUB-STEPPE COMMUNITIES

This task assesses small-mammal abundance in native and old-field vegetation of Eastern Washington. The seral-stage study areas consist of land that was previously cultivated and allowed to recover vegetatively for 35 years. The objectives are to determine whether differences in abundance or species composition of small mammals persists between undisturbed native sites and old-field environments. A secondary objective is to determine the merits of using relative and absolute abundance estimators to assess changes in small-mammal populations.

The old-field study areas were farmed to dryland wheat until 1942. From that point on, the area was left nearly undisturbed. Except for a few "islands" of shrubs, the land previously plowed remains dominated by cheatgrass, Bromus tectorum, and rye, Secale cereale. The surrounding und isturbed vegetation is dominated by two species of sage, Artemisia tripartita and Artemisia tridentata with an understory of bluebunch wheatgrass, Agropyron spicatum and Lupinus sp. Two additional trapping plots were established in these areas of native vegetation.

At each of the four plots, Sherman live traps were set $10-m$ apart in a square grid of ten rows of ten traps each. Trapping sessions consisted of five consecutive nights with trapping conducted concurrently at the four plots. Seven trapping sessions were conducted to assess small-mammal abundance during this study.

Among the various species captured, only the capture data on Perognathus parvus, the Great Basin pocket mouse, is sufficient for detailed analysis. Abundance of $P$. parvus was estimated on each of the four pTots using a single mark-recapture, or Lincoln index method. A sample of $n_{1}$ animals was marked and released during two days of live trapping; a second sample of $n_{2}$ animals was then collected during three days of removal trapping, of which $m$ were found to be marked.

Assuming capture probabilities were equal for animals on old fields and undisturbed sites, the numbers of individual animals captured per plot for each trap session were analyzed to compare abundance. Combining the replicate plots, proportional abundance was defined as the ratio of the animal abundance of one population $\left(N_{1}\right)$ to that of another $\left(N_{2}\right)$, say $K=N_{1} / N_{2}$. Using count data and assuming homogeneity in capture rates, est $i$ mated as $k=r_{1} / r_{2}$ where $r_{1}$ and $r_{2}$ denote the number of distinct animals recaptured on undisturbed and old fields, respectively.

During the seven trapping sessions, seven small mammal species were caught. They were, in order of abundance, the Great Basin Pocket Mouse (Perognathus parvus), deer mouse (Peromyscus maniculatus, western harvest mouse (Reithrodontomys megalotis), Merriam shrew (Sorex merriami), montane vole (Microtus montanus), northern pocket gopher (Thomomys talpoides), and the house mouse (Mus musculus). In total numbers captured, the native vegetation yielded approximately 3 times as many animals.

Abundance estimates of $P$. parvus using the single mark-capture method are given in Table 1. Calculations were only made for trapping sessions and locations with sufficient data for reliable estimates. On the 
TABLE 1. Abundance Estimates of $P$. parvus Using the Single Mark-Recapture Method

\begin{tabular}{|c|c|c|}
\hline Date & $\begin{array}{c}\text { Old Fields } \\
\hat{\mathrm{N}} \pm \operatorname{Var}(\hat{\mathrm{N}})\end{array}$ & $\begin{array}{c}\text { Pristine } \\
\hat{N} \pm \operatorname{Varr}(\hat{N})\end{array}$ \\
\hline November 1978 & N/A & $66.1 \pm 7.78$ \\
\hline March 1979 & $N / A$ & $32.4 \pm 39.4$ \\
\hline January 1979 & $69 \pm 18.9$ & $51.2 \pm 21.4$ \\
\hline November 1979 & $N / A$ & N/A \\
\hline March 1980 & $34.2 \pm 7.6$ & $36.2 \pm 16.6$ \\
\hline June 1980 & N/A & $26.2 \pm 32.6$ \\
\hline August 1980 & $N / A$ & $224 \pm 9900.0$ \\
\hline
\end{tabular}

$\mathrm{N} / \mathrm{A}=$ insufficient data old-field plots, only two occasions yielded enough captures to validate the estimation procedure. The pristine areas, however, logged enough captures (six out of the seven sessions) to make more accurate estimates. On the occasions when both areas had sufficient data, the estimate of the old fields was slightly higher for June 1979 and equivalent for March 1980. 


\title{
- Dynamics of Wild Populations(a)
}

\author{
Principal Investigator: L. L. Eberhardt
}

The objectives of this project are to evaluate the population dynamics of plants and animals and to conduct research on quantitative methodology suitable for evaluating the responses of natural populations to energy-related impacts.

Much DOE-supported laboratory and field research related to environmental impacts of energy development is concerned with relatively small organisms. Most of the direct studies of sites where such impacts actually occur are also focused on small animal forms. Both logistics and opportunity dictate these circumstances, because large animals do not fit laboratory space or budgets very well and often cannot be effectively studied within the confines of small field study sites. Nearly all evaluations of energy-related impacts on the larger species must thus come from inferences based on knowledge gained from long-term studies done under other auspices and for different purposes. Much of our recent work has been devoted to developing quant itative methods for such assessments.

We have been particularly concerned with methodology for appraising population dynamics of large mammals, and with census methodology. In cases where adequate data are available, adequate models exist for assessing population dynamics. Unfortunately, there is never enough data, so we must work with the data that can be obtained.

We have expended considerable effort in studying ways and means to simplify the analytical processes to conform to the kinds of information that are at hand. An immediate example is provided by a study that we conducted in conjunction with our work on a panel appointed by the National Academy of Sciences to oversee research on wild horses in the western states. In conjunction with Bureau of Land Management colleagues, we prepared a paper (in press) reporting on applications of this methodology. We have also been collaborating with researchers who are working with the endangered grizzly bear to make similar applications. The severe difficulties of censusing this species make the

(a) Subtask Agreement (RL). problem particularly awkward. Difficulties are compounded by the threat posed by encroaching human developments such as oil and gas exploration and development.

Another feature of the research has been the compilation and analysis of data on some 21 species and species groups of marine mammals. In addition to abundance and population parameters, we have been concerned with population regulatory mechanisms; the development of methods for assessing "optimal sustainable populations," in accord with the mandates of the Marine Mammal Protection Act; and the needs of effective management of the species concerned. In this effort, we have been cooperating with the U.S. Fish and Wildlife Service, the National Marine Fisheries Service, and the U.S. Marine Mammal Commission. Species and environments under study extend from the Antarctic to the Arctic, with the primary focus on waters under U.S. jurisdiction. The main aspects of energy development involved have to do with the Outer Continental Shelf program and transportation of $0 i 1$ and gas. Results of the study have been incorporated in an extensive draft report.

Our cooperative work with other DOE projects included a collaborative paper on metal uptake by aquatic macrophytes, and a joint paper on estimating radiation dose to Alaskan Eskimos based on consumption of strontium-90 in caribou flesh. A considerable effort was devoted to statistical evaluation of litterfall studies (mostly heavy elements) obtained in a biomonitoring project. One paper and two presentations resulted from this work. Three additional papers based on research conducted under a previously funded DOE project were prepared this year. Two publications dealt with methods for extrapolating results obtained using laboratory animals to larger mammals and to man. The third effort (evaluating simulation models) resulted from our efforts on a DOE sponsored ad hoc modeling group attempting to project the long-term consequences of transuranics in the environment. 
We have been involved in research and teaching at the University of Washington and Washington State University (where the principal investigators hold auxiliary appointments), and at the Center for Graduate Study in Richland. Participation in the efforts of several national committees continued throughout the year.

For further information on the statistical

methodology for field sampling refer to our Annual Report for 1981 on Interagency/

Contract Research, Ecological Sciences

Department. 


\section{- Quantifying Energy-Related Effects on Mobile Species}

Principal Investigator: J. R. Skalski

Other Investigators: M. A. Simmons, G. M. Trauger and D. S. Robson

Populations of wild animals are a resource which may compete with land-use demands of increased energy production. Impacts on animal populations can occur as a result of either habitat alterations or direct effects caused by the by-products of energy production. Populations of animals in higher trophic levels (for example, commercial and game species, and their prey) usually have high esthetic and economic value. These populations of mobile animals are also among the most difficult to census and monitor for impacts. No specific statistical or field study methodology now exists to compare quantitatively the animal abundance of temporally or spatially distinct populations. Without this capability, neither legal requirements for impact assessment nor the ability to ascertain the biological costs of impacts to an ecosystem can be made quantitatively.

\section{COMPARATIVE CENSUS METHODS}

Capture-tag-recapture studies are a traditional means of estimating the absolute abundance of fish and wildlife populations. The single mark-recapture method (e.g., Petersen or Lincoln Index) was investigated for the purpose of comparing the abundance of two spatially or temporally distinct populations, a procedure we call a comparative census.

Proportional abundance was defined as the ratio of the animal abundance of one population $\left(N_{2}\right)$ to that of another $\left(N_{1}\right)$, say $K=N_{2} / N_{1}$. Two alternative estimators of $K$ based on assumptions about catchability were constructed, and power curves for confidence interval estimators were developed using computer simulations (Figure 1). A chi-square test of homogeneity was also developed to test the assumption of equal catchability among animals of the two populations. When the homogeneity assumption is valid, the proportional abundance estimator based on two indices of relative abundance is from 2 to 20 times more efficient than the comparable estimator based on absolute abundance. This increase in sampling efficiency was achieved without an increase in field sampling effort. Analytic approximations for the power calculations were devised which $c$ an be used in the design of better comparative census studies (Figure 1 ).

Comparative census techniques and associated field design criteria are also being developed using removal sampling methods. These various census procedures are being investigated because of the need for diverse techniques of studying wild populations.

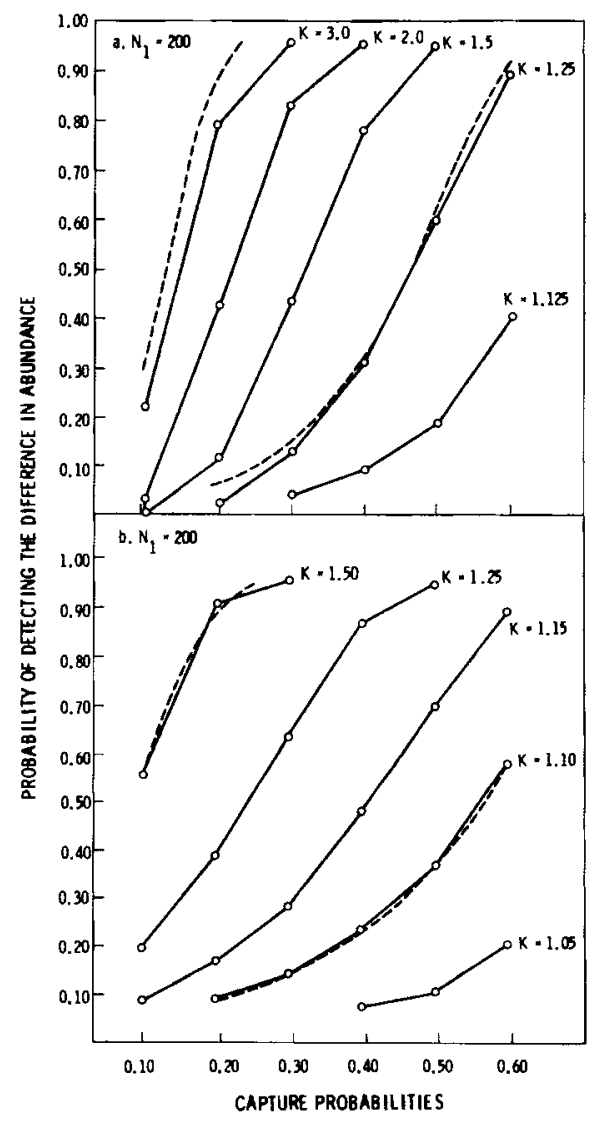

FIGURE 1. Power of Comparative Census Studies Using Single Mark-Recapture Methods to Detect Differences ( $\alpha=0.05$ ) between Populations with $N_{1}=200$ Animals and $N_{2}=K N_{1}$ for Various Capture Rates when Employing (A) Absolute Abundance Estimates or (B) Indices of Abundance. Dotted lines based on analytic approximations. 


\section{TESTS OF TREATMENT EFFECTS}

To attribute differences in animal abundance to treatment effects, the variation in abundance among populations treated alike must be estimated. In comparative censuses, no measure of experimental error is available. Uses of the sampling error of comparative censuses are limited solely to describing the extent of inherent differences between populations.

While it cannot be expected that natural populations will be distributed in accordance with any precise statistical model, the numbers of animals residing on study plots have been modeled historically by Poisson, binomial and negative binomial distributions. When the dispersion mechanisms of animal abundance are assumed, likelihood ratio tests, which specify the nature of this plot-to-plot dispersion in abundance, have been found to outperform traditional normal theory tests. Normal theory tests exhibit both much larger Type I and II experimental errors. Type I error is committed when an impact is declared when none actually exists, and a type II error occurs when no impact is declared when an impact really does exist.

Currently, nonparametric statistical methods and test statistics applicable to a range of possible distributions are being developed for use in testing for treatment effects on mobile species. Monte Carlo programs developed to simulate mark-recapture studies on populations whose sizes are distributed according to a variety of statistical distributions are being used to evaluate the behavior of possible test statistics. Results are permitting the design of more powerful and efficient field studies to detect impacts on populations of mobile species.

A common means of monitoring animal abundance across replicate populations is to use a series of catch-per-unit effort (CPUE) samplings. These catch-effort procedures such as trap-line studies of small mammals and trawl studies of pelagic fish have traditionally standardized procedures to maintain constant sampling effort. Research on probabilistic models revealed that such constanteffort procedures are incapable of differentiating the causes for a change in the catchrate between shifts in animal abundance and shifts in the catchability of the species harvested. A variable-effort technique was developed and field tested that reallocates effort unequally between replicate populations. This variable-effort census procedure is capable of providing regional estimates of mean animal abundance and its variance, without increasing the overall effort of traditional CPUE studies. 


\title{
- Restoration of Surface Mined Lands
}

\author{
Principal Investigator: R. H. Sauer
}

Associate Investigators: L. A. Nieves and M. L. Warner

The goal of this program is to develop a method of restoring the vegetative productivity of lands that have been disturbed by surface mining in the arid regions of the U.S. Because river and well water are scarce in arid regions, we have studied the technological and economic feasibility of using water harvesting to supply the irrigation water for reestablishing vegetation. Technical feasibility was demonstrated by the greater vegetative growth and water content in the areas receiving the runoff from the water-harvested slopes. The economic feasibility was projected from estimates of savings based on reduced earth moving and the market value and productivity of selected crops. These preliminary conclusions need to be refined by a complete data analysis. Further studies are also needed on improved slope treatments that will increase runoff and on selected crops adapted to water harvesting.

The purpose of the program is to develop for industry a means of reclaiming arid mined lands with minimal use of well and river water for irrigation. This purpose is consistent with the Department of Energy's goal of producing energy with minimal disruption of the environment. The difficulty of establishing vegetation on mined western lands is largely due to the general aridity of the region. Water resources are scarce and should not be used for irrigating low-value crops on mined lands. The Pacific Northwest Laboratory (PNL) approach to restoration uses water harvesting, which is the gathering and storing of rainfall runoff, to supply irrigation water. Water harvesting reclamation has been used at two coal mines in cooperation with the University of Arizona and the Peabody Coal Company.

In water harvesting reclamation, the spoil banks are slightly smoothed and leveled and used as catchment areas to intercept precipitation and direct it to the valley floor. The crops are cultivated in the topsoil placed in the valleys between the slopes. This procedure facilitates reclaiming mined lands for agricultural use and providing water for irrigation in an otherwise arid region.

Research has been conducted at three sites: Hanford, Washington; Kayenta, Arizona; and Nucla, Colorado. The Hanford site has served as a testing facility for untried methods. When a method has been evaluated, it may be used at the operating Peabody coal mines at Nuc la and Kayenta.

The Nucla site was uniformly planted this spring on the catchment areas and valley floors with a mixture of galleta grass, Indian rice grass, side oats gramma, crested wheatgrass and alfalfa. Our intent is to develop a water harvesting system that will meet the current requirements of reclamation legislation. Data will be reported next year after the completion of the first growing season.

The Kayenta site has been used to test several crop types and four slope treatments designed to increase runoff. The crops tested this year (pinyon pine, sorghum, alfalfa, and Indian corn), were chosen for their adaptability to. water harvesting and their value in the 10cal Navajo Indian economy. The slope treatment (seeded with grasses, untreated, compacted, and salted and compacted), produced more favorable conditions and more vegetation than an adjacent area that was reclaimed conventionally without benefit of water harvesting. The soil water data from Kayenta (Table 1) show a clear trend for the valleys to be wetter than the slopes supplying the water, which indicates that the slopes are effective rainfall collectors. The soil-water data were collected when lush vegetation was using the water in the valleys, so that without vegetation, there would be even more water in the valleys.

An economic analysis based on available data from Kayenta has suggested that using the compacted slope treatment to irrigate alfalfa is economically feasible. This projection should be tested with production data from this site.

The Hanford site has provided, in addition to other information, data on the effectiveness of several slope treatments to increase runoff. The valleys are also oriented in either north-south or east-west directions to test the effectiveness of the slopes in protecting the crops from the strong prevailing winds, usually from the west. This year, four varieties of alfalfa were planted in a cooperative effort with the Washington State University 
TABLE 1. Soil Water Content (\%) at the Kayenta Site

\begin{tabular}{|c|c|c|c|c|}
\hline \multirow[b]{2}{*}{ Sample Location } & \multicolumn{4}{|c|}{ Date } \\
\hline & $5-20-81$ & $6-26-81$ & $7-27-81$ & $8-19-81$ \\
\hline $\begin{array}{l}3 \text { to } 6 \mathrm{~cm} \text { Depth } \\
\text { Slopes } \\
\text { Plowed Valleys } \\
\text { Unplowed Valleys }\end{array}$ & $\begin{array}{l}10.09 \pm 1.61(\mathrm{a}) \\
14.22 \pm 2.68 \\
13.69 \pm 2.15\end{array}$ & $\begin{array}{l}4.64 \pm 0.59 \\
3.91 \pm 1.27 \\
3.72 \pm 1.48\end{array}$ & $\begin{array}{r}5.35 \pm 0.62 \\
13.57 \pm 2.34 \\
6.39 \pm 2.58\end{array}$ & $\begin{array}{l}4.46 \pm 0.52 \\
8.14 \pm 2.18 \\
3.36 \pm 0.49\end{array}$ \\
\hline $\begin{array}{l}15 \text { to } 20 \mathrm{~cm} \text { Depth } \\
\text { Slopes } \\
\text { Plowed Valleys } \\
\text { Unplowed Valleys }\end{array}$ & $\begin{array}{l}12.01 \pm 2.93 \\
15.47 \pm 3.60 \\
12.88 \pm 2.49\end{array}$ & $\begin{array}{l}6.26 \pm 1.25 \\
7.73 \pm 2.35 \\
5.33 \pm 1.42\end{array}$ & $\begin{array}{r}8.39 \pm 1.55 \\
15.99 \pm 1.86 \\
7.25 \pm 2.57\end{array}$ & $\begin{array}{r}5.18 \pm 0.56 \\
10.59 \pm 2.56 \\
5.12 \pm 0.64\end{array}$ \\
\hline Precipitation (mm) & 1.3 & 15.2 & 74.9 & 7.6 \\
\hline
\end{tabular}

(a) Means $\pm 95 \%$ confidence limits.

Agricultural Experiment station at Prosser, Washington. Results of the study will not be available until after the end of the growing season.

Data on soil water content from February 1977 through July 1981 have been preliminarily analyzed. The rubber-sheeting slope treatment provided the most soil water, followed by paraffin (Table 2). The remaining treatments (bare slope, flat control, no adjacent slopes, and rubberized asphalt) were not notably effective in providing runoff. The rubberized asphalt and paraffin treatments would have been more effective if the material had been applied in sufficient quantitiy to flow under the cobbles on the surface and, thereby, seal the surface totally.

Because measurement of soil water content was central to determining the effectiveness of the various slope treatments, it was necessary to track soil water content. An instrument was designed and fabricated by PNL to provide adequate accuracy and to overcome capacitance problems in the long leads between the soil water sensors and the central switching station. This instrument has a patent pending and has permitted a rapid and accurate reading of the soil water content.

This research has shown that water harvesting reclamation is technically and economically
TABLE 2. Ranking of Catchment-Area Treatments at Hanford, Washington(a)

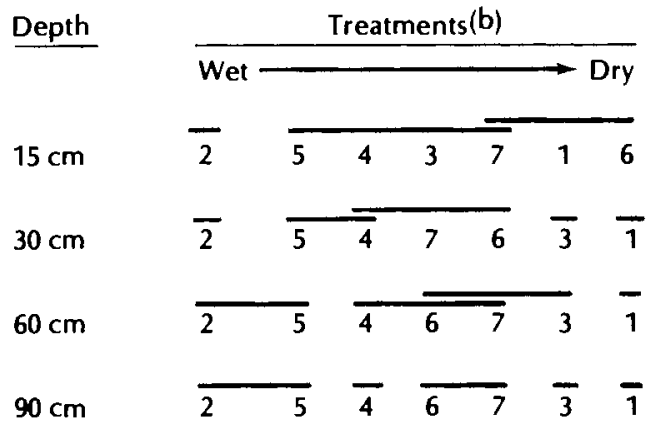

(a) Treatments under common overline are not different $(P=0.05$ Duncan Multiple Range Test)

(b) 1 = flat control N-S, 2 = rubber sheeting N-S, $3=$ bare slope $N-S, 4=$ paraffin $N-S, 5=$ paraffin $E-W, 6=$ bare slope $\mathrm{E}-\mathrm{W}, 7=$ rubberized asphalt $\mathrm{E}-\mathrm{W}$.

feasible, and that more research is needed to refine the slope treatments and to select crops adapted to the conditions provided by water harvesting. More work is necessary to design water harvesting reclamation systems suitable for commercial application at operating coal mines. 


\title{
- Long-Term Ecological Monitoring
}

\author{
Principal Investigator: W. T. Hinds \\ Associate Investigators: R. E. Fitzner, M. C. McShane, J. R. Skalski and J. M. Thomas
}

The objective of this program is to develop and use cost-effective monitoring designs able to detect slowly-paced ecological responses to chronic pollution stress. This objective is fundamentally different than most monitoring efforts, which concentrate on responses to acute pollution episodes or sitespecific problems. The monitoring data will form a region-wide baseline for ecological activities that can be compared with levels of the same activities in future decades.

Pacific Northwest Laboratory's ecological monitoring task is designed to monitor the vigor of widespread and economically important forest types by collecting leaf, litter, and needlefall; and monitor the presence and abundance of widespread toxic elements in food chains by collecting feces and rejected food scraps from target species. The forest monitoring effort has shown that sampling error (within-plot error) can be made very small if proper sampling designs are used. The food chain contamination effort has shown that appropriately designed sampling can differentiate atmospheric contamination of samples from bona fide contamination in prey items in food webs leading to a cosmopolitan predator (Great Blue Heron).

\section{MONITORING DESIGN AND DEVELOPMENT}

Ecological monitoring is the purposeful and repeated examination of the state or condition of organisms in relation to actual or potential impact from external stress. It differs from environmental monitoring in its emphasis on organisms, and it differs from most socalled biological monitoring because its focus is on the organism rather than the organism's environment. The objective of ecological monitoring efforts in general is to locate changes in organism presence, abundance, productivity, and vigor that are actually or potentially caused by man-made stress. The Pacific Northwest Laboratory (PNL) research aims to create ecologically meaningful, statistically credible, and affordable ecological monitoring designs.

Perhaps the most important design decision in ecological monitoring is to specify correctly the required statistical replication. Only slightly less important is to select ecologically appropriate biotic targets or activities for study. Determining the cost of achieving acceptable levels of statistical sensitivity and power must be made part of the design effort.

Unfortunately, not all ecological monitoring efforts have satisfied these criteria. Sometimes the difficulty is conceptual. For example, "whole ecosystem" approaches can require such large expenditures at one site that replication at other sites is precluded. Sta- tistical design is another problem, because often ecological "replicates" are actually merely sub-samples. A third problem is cost, both as a total and as distributed among tasks within the effort. To solve these fundamental problems, the PNL Long-Term Ecological Monitoring task will develop and use methods able to detect subtle, long-term changes in ecosystems of the western United States.

Ecological monitoring methods probably should not be simple extrapolations of standard ecological methods. Pacific Northwest Laboratory's approach, can be outlined on a simple flow chart (Figure 1), starting with objectives and ecological judgements and ending with assessment of the statistical power and sensitivity attached to affordable levels of effort. A critical step must be made from methods that are ecologically pertinent or descriptive to methods that yield quantitative estimates of precision and power. This crucial step must be made or the data are suitable only for ecological descriptions. The information required to make this step nearly always requires expensive mult iple-plot designs. However, this information is necessary before the methods can be assessed for their likelihood of yielding wrong answers. If a method can be shown to be both ecologically appropriate and statistically intelligible, then the minimum cost of providing adequate data must be assessed. Only after a method has been shown to be ecologically meaningful, statistically credible and affordable, can it be recommended for long-term use. 


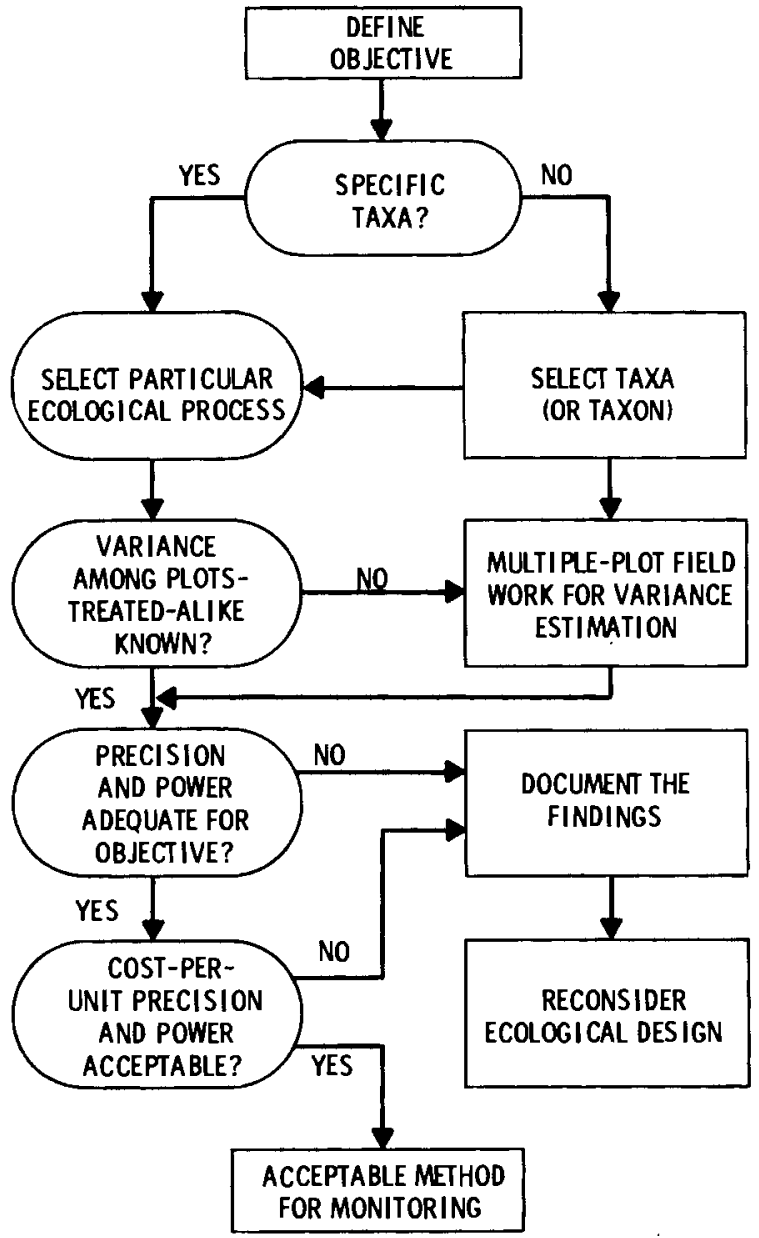

FIGURE 1. Sequence Used for Collecting Information When Developing a Monitoring Method

\section{FOREST MONITORING}

Litterfall has been collected monthly since October-November 1978 at four pristine forested sites in the Pacific Northwest. Mean litterfall and needlefall $\left[\left(\mathrm{g} / \mathrm{m}^{2}\right) /\right.$ day $]$ and species composition of need les were estimated monthly at each site. Table 1 shows annual needlefall and litterfall and median precision of these estimates, based on data for 1978 to 1980 , for each of the four sites. Determining the species composition of needlefall proved to be extremely time consuming: more than 2 hours were required to process each sample. Handling the 1250 samples collected yearly required a time commitment of about 3000 hours. The data indicate that total needlefall, rather than species-specific data, is usually more precise and is always less costly to obtain.
TABLE 1. Annual Production of Needles and Total Litter (1978 through 1980)

\begin{tabular}{|c|c|c|c|c|}
\hline Site & $\begin{array}{c}\text { Needlefall } \\
\left(\mathrm{g} / \mathrm{m}^{2}\right)\end{array}$ & $\begin{array}{c}\text { Median } \\
\text { Precision } \\
(\%) \\
\end{array}$ & $\begin{array}{c}\text { Litterfall } \\
\left(\mathrm{g} / \mathrm{m}^{2}\right) \\
\end{array}$ & $\begin{array}{c}\text { Median } \\
\text { Precision } \\
(\%) \\
\end{array}$ \\
\hline Wind River & 226 & 18.5 & 299 & 18.3 \\
\hline H. J. Andrews & 197 & 8.9 & 292 & 12.1 \\
\hline Quinault Lake & 248 & 11.5 & 566 & 22.6 \\
\hline Neskowin Crest & 485 & 9.0 & 752 & 12.5 \\
\hline
\end{tabular}

One of the design problems in forest monitoring studies involves sampler size and the effect it has on sampling precision. A study completed in FY 1981 addressed this problem using four different size samplers ranging from 0.01 to $0.93 \mathrm{~m}^{2}$ in area. Detailed records were kept on the amount of time required to separate needles and epiphytes from other debris for each sampler size. This information, along with a statistical precision analysis of the needle-fall estimates, will be used to design a sampler of optimal size per unit effort and precision.

\section{FOOD CHAIN CONTAMINATION}

Food scrap and feces cast from nests of great blue herons were sampled by placing large cheesecloth blankets under nests. The collection was then analyzed for trace contaminants of lead, cadmium, and mercury. To separate contaminants in the food chain from atmospheric deposition, control collectors were placed under nearby trees that resembled trees supporting the nests. Results reported in Table 2 show that the toxic elements in the food chain can be separated from airborne contamination. The data also show that the herons are subjected to wide ranges in food chain contamination, depending upon their locality.

The data reported in Table 2 are fairly noisy, with standard errors about $20 \%$ of the mean and standard deviations about $50 \%$ of the mean. This is about average for field measurement, but much larger than is desirable for ecological monitoring objectives. Design modifications will be made to diminish the standard deviations, which will help reduce both Type $I$ and Type II errors in the final design. 
TABLE 2. Average Lead, Cadmium and Mercury Content (ppm \pm standard error) in

Debris Cast from Heron Nests at Colonies in Washington and Idaho. Treatment = cheesecloth strips receiving heron debris; control = cheesecloth strips with no heron debris; debris $=$ treatment minus control.

Location

$\begin{array}{r}\text { Lead } \\ \hline \\ 46 \pm 7.4 \\ 5.7 \pm 1.3 \\ \hline\end{array}$

Cadmium

Mercury

Lake Chatcolet, Idaho

Treatment $(n=6)$

Control $(n=2)$

$40(\mathrm{a}) \pm 7.4$

$1.8 \pm 0.08$

$0.22 \pm 0.030$

$0.28 \pm 0.011$

Debris

Tacoma, Washington

Treatment $(n=6)$

Control $(n=2)$

\begin{tabular}{l}
$29 \pm 5.3$ \\
$20 \pm 1.8$ \\
\hline $8 \pm 5.6$
\end{tabular}

$1.6(a) \pm 0.08$ $0.085 \pm 0.016$

Debris

$8 \pm 5.6$

$0.19 \pm 0.020$

$0.24 \pm 0$

$0.20(b) \pm 0.016$

Richland, Washington

Treatment $(n=6)$

Control $(n=2)$

Debris

$3.3 \pm 0.35$

(c)

$0.17 \pm 0.019$

$0.14 \pm 0.061$

$1.4 \pm 0.42$

$0.45 \pm 0.040$

$1.9 \pm 0.42$ $0.11 \pm 0.08$

$0.10 \pm 0.007$

$<0.05$

Potholes Reservoir, Washington

Treatment $(n=6)$

Control $(n=2)$

$0.79 \pm 0.06$

$0.34 \pm 0.09$

$>0.05$

Debris

$1.0 \pm 0.38$

$0.092 \pm 0.013$

$0.14 \pm 0.045$

$0.059 \pm 0.004$

(c)

(c)

(c)

(a) Control is significantly $(\mathbf{P}<0.05)$ different from treatment.

(b) Control is significantly $(P<0.10)$ different from treatment.

(c) No significant statistical difference. 



\title{
- Application of Long-Term Chemical Biobarriers for U-Tailings(a)
}

\author{
Principal Investigator: J. F. Cline
}

Associate Investigators: D. A. Cataldo, F. G. Burton and W. E. Skiens, K. A. Gano and L. E. Rogers

The objective of this project is to develop and evaluate the effectiveness of physical and chemical barriers that are designed to prevent plant and animal breachment of uranium tailings containment systems for extended periods of time.

DEVELOPMENT OF POLYMERIC CARRIER/DELIVERY (PCD) SYSTEMS AND DETERMINATION OF HERBICIDE RELEASE RATES

A major effort this year was spent in determining the final combination of polymer, pellet size, and trifluralin loading used in this year's field trial at Grand Junction, Colorado. The effective life of the PCD system as a root barrier can be lengthened by increasing the trifluralin loading and reducing its release rate from the pellets. Using the fact that surface area increases as the square of the diameter while volume increases as the cube of the diameter, we predicted that a pellet $9 \mathrm{~mm}$ in diameter and $9 \mathrm{~mm}$ long will have a lifetime in excess of 100 years. This pellet size also allows the use of conventional equipment for spreading in the field.

These fabricated pellets contained $23.4 \%$ trifluralin. Since the amount of trifluralin that $c$ an be retained in a polymer depends on the polymer type, we mixed various concentrations of trifluralin with a number of polymers. Once the pellet or sheet containing the trifluralin was fabricated, a weighed piece was extracted to determine the amount of trifluralin contained. Fillers such as carbon black were added to some polymers to determine whether the filler would increase the amount of trifluralin retained. Some resulting data are shown in Table 1 . Based on these analyses, we were able to eliminate several polymers, e.g., polyurethane and polyethylene-vinyl acetate, as potential reservoirs for the delivery system.

The slow-release-pellet PCD system was formulated for use at the Grand Junction U-tailings test site. The pellets were molded cyl-

(a) This work was sponsored for FY 1980 through FY 1982 by DOE Albuquerque Operations Office, Uranium Mill Tailings Project office, Albuquerque, New Mexico.
TABLE 1. Different Trifluralin Retention Properties of Several Polymers and the Effect of Adding Carbon Black on Trifluralin Retention and Stability of the PCD System

\begin{tabular}{|c|c|c|}
\hline Polymer & $\begin{array}{c}\text { Targeted } \\
\text { Loading, pph }\end{array}$ & $\begin{array}{c}\text { Analyzed } \\
\text { Loading, pph }\end{array}$ \\
\hline Polyvinyl chloride & $\begin{array}{l}10 \\
30 \\
50\end{array}$ & $\begin{array}{c}10.1 \\
22.1 \\
48.6\end{array}$ \\
\hline $\begin{array}{l}\text { Poly rubber } \\
\text { (butadiene-styrene) }\end{array}$ & $\begin{array}{l}10 \\
30 \\
50\end{array}$ & $\begin{array}{r}9.0 \\
20.6 \\
36.6\end{array}$ \\
\hline Polyurethane & 30 & 4.3 \\
\hline $\begin{array}{l}\text { Polyethylene-vinyl } \\
\text { acetate }\end{array}$ & $\begin{array}{l}30 \\
50\end{array}$ & $\begin{array}{r}9.5 \\
15.7\end{array}$ \\
\hline $\begin{array}{l}\text { Polyethylene, } \\
\text { no carbon black }\end{array}$ & 30 & 16.0 \\
\hline $\begin{array}{l}\text { Polyethylene, } \\
25 \text { pph carbon black }\end{array}$ & 30 & 18.8 \\
\hline $\begin{array}{l}\text { Polyethylene, } \\
40 \text { pph carbon black }\end{array}$ & 30 & 13.1 \\
\hline $\begin{array}{l}\text { Polyethylene, } \\
40 \text { pph carbon black }\end{array}$ & 50 & 31.3 \\
\hline
\end{tabular}

inders, $9 \times 9 \mathrm{~mm}$, made from a low-density polyethylene material with a melt index of 22. The formulation included $20 \%$ carbon black to increase the trifluralin reservoir within the pellet and to slow the release rate of the herbicide from the PCD system. The trifluralin loading of the pellets was $23.4 \%$. A small portion of the trifluralin (1.3\%) was on the surface of the pellets and was released rapidly leaving $22.1 \%$ trifluralin for slow release. 


\section{PHYTOTOXICITY AND DEGRADATION STUDIES}

During this year, studies were conducted in the following areas: 1) fourteen plant species were screened to determine soil concentrations of trifluralin that will inhibit root elongations, 2) studies were continued to determine soil trifluralin concentrations when equilibrium was achieved within the soil around the implanted PCD devices, 3) studies were extended to determine the effective diffusion path length for trifluralin in soil after release from PCD devices, and 4) studies were initiated to evaluate the effect of soil moisture content on trifluralin releases from PCD systems and on accumulation in soil.

Previous lysimeter studies to determine the concentrations of trifluralin in soils required to stop root elongation showed a wide range of plant sensitivity to the toxin. Russian thistle roots were controlled at $1.0 \mathrm{ppm}$, while crowned vetch and tansy mustard continued growth until concentrations of $\sim 7 \mathrm{ppm}$ were reached (Table 2). It was noted that lateral roots of the crowned vetch and tansy mustard passed the treated zone along the lysimeter wall. Plant species exhibiting this tendency were added to a list of plants previously tested for evaluation. Results of our studies (Table 2) show that soil trifluralin levels of $\sim 7 \mathrm{ppm}$ will be needed to inhibit root elongation.

Determination was made of the equilibrium soil concentrations of trifluralin resulting from implanting PCD devices in the soil. A

TABLE 2. Soil Concentrations of Trifluralin Required to Inhibit Root Elongation

\begin{tabular}{lcc} 
Plant Species & $\begin{array}{c}\text { Soil Concentration Range, } \\
\text { ppm }\end{array}$ \\
\cline { 1 - 2 } $\begin{array}{l}\text { Russian thistle } \\
\text { Tansy mustard }\end{array}$ & $0.3-0.5$ \\
Fourwing saltbrush & & $4.1-5.7$ \\
Gardner saltbrush & $1.8-3.5$ \\
Winterfat & & $4.2-6.1$ \\
Crown vetch & $0.2-0.5$ \\
Rocky Mountain penstemon & & $5.8-6.5$ \\
Palmer penstemon & $0.9-1.5$ \\
Bluebunch wheatgrass & & $1.4-2.1$ \\
Thickspike wheatgrass & & $0.5-0.8$ \\
Russian wild rye & $0.6-1.1$ \\
Blue flax & & $0.5-1.1$ \\
Bitterbrush & & $1.4-2.5$ \\
& $0.4-2.0$
\end{tabular}

Profax PS-1600 PCD device placed in soil at three loading rates $(0.5-, 1.0-$, and $3.0-9$ pellets/400 g soil) behaved predictably based on in vitro tests. Equilibrium soil concentrations, where steady-state release from the device and decomposition rates were constant, were found to be $0.7,1.5$ and $4.5 \mathrm{ppm}$ in soil for the three loading rates, and were obtained after 80 days of incubation. The cumulated half-life of trifluralin in a silt loam soil after release from the pellets was determined to be $\sim 50$ days. These losses were regulated by microbial decomposition, chemical degradation and volatilization of trifluralin in the soil.

The time that was necessary for trifluralin to reach equilibrium in the soil after placing the pellets in the soil was $\sim 30$ days and remained constant for the remainder of the duration of the 180-day study period. Preliminary studies showed the longitudinal movement of trifluralin in the soil was $<6 \mathrm{~cm}$ from the point of placement.

\section{GREENHOUSE AND FIELD STUDIES}

The $9 \times 9-m m$ pellets (PCD system) were effective in stopping root elongations in the greenhouse studies. These pellets were layered in small growth containers on 2.54and $5.08-\mathrm{cm}$ centers, 16 in. below the soil surface.

Similar pellets were placed over the asphalt emulsion and multilayered earthen radon seals at the Grand Junction test sites. Two densities, 144 pellets $/ 22 \mathrm{~cm}^{2}(2.54-\mathrm{cm}$ centers) and 36 pellets $/ 22 \mathrm{~cm}^{2}$ (5.08-cm centers) were placed in soil $\sim 5.08 \mathrm{~cm}$ above the seal and then covered with $-61 \mathrm{~cm}$ of topsoil. Concentrations of trifluralin in the soil near the pellets will be determined at a later date.

\section{ANIMAL INTRUSION STUDIES}

A physical barrier system is needed to prevent burrowing animal intrusions into seals placed over U-tailings. Previous studies have shown that layers of various sized stones are effective as long-term barriers to animal intrusion. Studies were conducted at the Grand Junction U-tailings site and at the Hanford laboratory to determine the effectiveness of various barriers.

Grand Junction Test Site. In 1980, a 30-cmthick layer of rocks $3.8 \mathrm{~cm}$ in diameter was placed over a section of the asphalt emulsion seal. The rock layer was then covered with soil. Wire mesh enclosures were built over 
the rock and soil barrier. The wire mesh was extended into the backfi11. Prairie dogs were then placed in the enclosures and observed for burrowing activity. There was no evidence of any penetrations of the asphalt emulsion seal by the prairie dogs. Many of the rocks were excavated, and tunnels were dug through the backfill and into the rock layer. The prairie dogs escaped through the tunnels. We concluded that the rock size used was too small and that the size and mass of the rocks used in a barrier must be correlated with the weight of the animal.

Hanford Test Site. A facility was constructed at the Hanford site to test the effectiveness of crushed rock as a barrier against animal and ant intrusions into radon seals placed over tailings. Four boxes $(1.2 \times 1.2 \times 1.2 \mathrm{~m})$ were buried in the ground and surrounded with wire mesh to confine the animals and force them to dig into the boxes containing various barrier configurations (Figure 1 ).

Our replicate was made of each of the three barrier configurations and the control. The configurations were 1) a crushed rock layer placed over a clay-mix seal, 2) a crushed rock layer placed over an asphalt emulsion seal, and 3) an asphalt emulsion seal only. Forty-

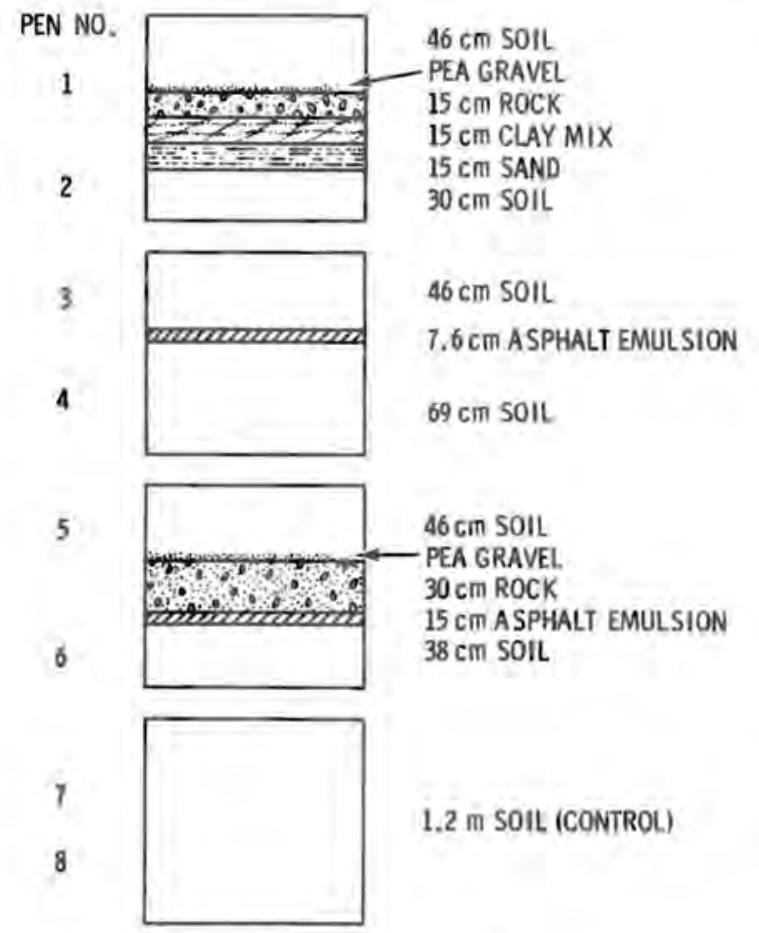

FIGURE 1. Three Different Barrier Configurations Tested at Hanford. A control was used to compare burrowing without a barrier. six $\mathrm{cm}$ of top soil was placed over each barrier configuration. The controls had $1.2 \mathrm{~m}$ of top soil with no barrier.

Ground squirrels were placed in the enclosures and allowed to dig in the boxes for at least 8 weeks. In April 1981, the squirrels were removed from their pens, and the tunnels were studied. To permit this, a trench was dug alongside each box and the side panel removed. This exposed the barriers and tunnels without disturbing the seal configurations.

The top soil was carefully removed and the tunneling diagrammed. The ground squirrels had not penetrated the crushed rock layers over the multiclay seal or over the asphalt emulsion seal; nor did they penetrate the asphalt seal without a rock barrier. Tunnels and nest chambers had been constructed at the barrier interface in all cases. However, the animals in the control boxes had excavated tunnels and made nest chambers to a depth greater than $91 \mathrm{~cm}$, showing that ground squirrels generally burrow deeper than the $46 \mathrm{~cm}$ of soil cover placed over each barrier.

After the ground squirrel study was completed, the burrow boxes were reconstructed by replacing the wooden side panels and the top soil over the same types of barriers. Prairie dogs were then introduced to pens; the females were spayed to prevent propagation of the species in case they escaped during the study. Prairie dogs are three to four times larger than the ground squirrels and much stronger burrowers. Common to many areas of the West, they are likely to be the most powerful burrowing rodent encountered at uranium tailings piles. The prairie dogs were maintained in the enclosures for 8 weeks. The animals were removed and the burrow boxes examined in the same manner as before. The effectiveness of the different barriers ranged from partial penetration to complete exclusion. No sign of penetration of the asphalt emulsion barrier was observed. Some penetration of the rock Tayer over the asphalt emulsion layer was observed. The extent of burrowing in the boxes containing the multilayer earth barrier was similar to that observed over the asphalt emulsion barriers. The tunnels were excavated to about the same depth $(15 \mathrm{~cm})$. The rock Tayers were on $1 \mathrm{y} \sim 15 \mathrm{~cm}$ thick over a $\sim 15 \mathrm{~cm}$ clay mixture in these boxes. The deepest tunnel in this treatment appeared to pass through the rock and stop at the clay layer. In the control without any barrier, the prairie dog had tunneled $-20 \mathrm{~cm}$ below the bottom of the box $(1.2 \mathrm{~m})$. 



\title{
- Revegetation/Rock Cover for Stabilization of Inactive U-Tailings Sites
}

\author{
Principal Investigators: P. A. Beedlow and L. L. Cadwell
}

Associate Investigators: M. C. McShane, D. S. Daly, J. R. Skalski, T. J. Bander, D. W. Mayer, R. L. Skaggs and $\mathbf{W}$. Walters

Soil placed over any sealant/barrier system can provide a protective mantle if the soil is not lost by erosion. Vegetation is an attractive choice for controlling erosion because it can provide an economic self-renewing cover that serves to reduce erosion by both wind and water. Vegetation alone, however, may not adequately stabilize the surface in extremely arid areas. In those areas, a properly designed surface treatment of rock cover, perhaps in conjunction with vegetation, may be necessary to stabilize the tailings surfaces.

The objective of this program is to establish guidelines for surface stabilization that are compatible with sealant/barrier systems and that are suited to soils and climates at inactive uranium mill tailings sites. These guidelines will provide the means to estimate potential vegetation cover, potential erosion, effects of surface treatments on sealant/barrier systems, and costs of vegetation and rock covers. Methods for establishing vegetation on sealed tailings will also be provided.

\section{TEST PLOTS}

The objectives of this task are to evaluate the interactions between vegetation and sealant/barrier systems, evaluate the effects of rock covers on soil water and vegetation establishment, and examine vegetation establishment strategies for use with rock cover. Tests to evaluate the interactions between vegetation and sealant/barrier systems are being conducted at the Grand Junction test site in conjunction with Uranium Mill Tailings Remedial Action Projects (UMTRAP), which test sealants, biological barriers and liners. A second test plot was constructed on the San Juan coal mine in Waterflow, New Mexico (approximately 11 miles west of Farmington). Construction of the plot was finished in $\mathrm{Au}-$ gust. At this site, the effects of irrigation and rock covers on soil moisture and plant establishment will be evaluated.

Grand Junction Test Plot. At this test facility, the revegetation project is examining the relationships between vegetation and technologies for containing radon. Interaction between vegetation and the herbicide barriers intended to limit plant root penetration into sealant systems is also being studied. The effects of soil depth on plant rooting are being investigated to determine minimum planting requirements. Soil moisture responses to plant cover and the sealants will be monitored to assess the effects of the cover systems on soil water. This will provide a basis for evaluating potential cover-treatment impacts on revegetation success.
The test plots and surrounding disturbed areas were seeded in early November 1980. The seeded area was first mulched and fertilized using a commercial fertilizer spreader. Grass fiber mulch was applied at a rate of approximately 1 ton/acre. Fertilizer (20\% nitrogen, $20 \%$ phosphorous, $20 \%$ potassium) was applied at a rate of approximately $1201 \mathrm{~b} / \mathrm{acre}$. Seeds were applied at a rate of 18 to 20 ib of pure live seed per acre. The plant species used to seed the site were chosen for their adaptation to the local environment, proven success in revegetating disturbed areas, and availability.

One of the primary objectives of the Grand Junction test-plot work is to evaluate the influence of asphalt emulsion, multilayer earth, and root barrier herbicide treatments on the establishment of a stabilizing vegetative cover. Soil moisture regimes are likely to be influenced by tailings cover treatments. Because soil moisture is critical to the establishment and maintenance of vegetation on disturbed sites in arid and semi-arid regions, it is an important parameter for study on the test plot.

Three hundred eighty-two soil moisture blocks, previously calibrated in the laboratory, were installed in the treatment plots during october and November 1980. The blocks were placed at $0.1-m, 0.3-m, 0.6-m$ and $1.2-m$ depths as permitted by the depth of soil cover. Comparisons will be made among soil treatments and among soil depths. 
An irrigation system was installed on the site in April to insure seed germination and maintenance for vegetative cover. Monthly soil moisture measurements were initiated in March. In May, the site was sampled for gemination from the fall seeding. Grasses and forbs from the applied seed mixture and two infacing weed species were present. Plant species sown in November that had germinated were Agropyron sp. (wheatgrass), Atriplex sp. (saltbush), Oryzopsis hymenoides (Indian ricegrass), Puccinel1i Temoni (1emmon's alkali grass), Sporobolus airoides (alkali sacaton), Amaranthus retroflexus (redroot pigweed), and Sphaeralcea coccinea (scarlet globemallow). Two invading species, Salsola kali (Russian thistle) and Kochia prostrata (prostrate summercypress) were also present. Germination data are summarized in Table 1. Seeded grasses and Salsola kali, a volunteer, dominated at germination. These data indicate that gemination was not uniform across the site. No statistical correlation between germination and soil moisture was found.

San Juan Test Plot. In cooperation with the San Juan Coal Co., a second test plot was constructed in August 1981. At this site, the effects of irrigation and rock covers on soil moisture and plant establishment will be evaluated. The test-plot design consists of three major surface treatments: topsoiled, topsoiled plus sorted cobble approximately $5 \mathrm{~cm}$ in diameter, and topsoiled plus unsorted stream deposits.
Each of these blocks are subdivided into the following plant treatments on plots $4.6 \times$ $7.6 \mathrm{~m}$, arranged on both sides of a sprinkler irrigation line: a) seeded with forb/shrubdominant mix, b) seeded with grass-dominant mix, c) seeded with forb/shrub-dominant mix + shrub transplants, d) seeded with grassdominant mix + shrub transplants, e) planted with shrub transplants only, and f) control-no planting or seeding.

A unique system of applying variable rates of irrigation water is used at the plots. The system applies a high rate of water at one end of a plot but decreases to zero at the other end, making it possible to determine the minimum amount of water necessary for plant establishment. Each increment of distance away from the line source represents a sub-plot where plant establishment and growth can be correlated with a given amount of water (as measured with collection cups). Irrigation is applied immediately after seeding and repeated after 2,4 , and 6 weeks in the fall. Irrigation will be resumed in the spring (possibly April) on a 3-week interval until July. The rate will vary from zero to $2.5 \mathrm{~cm}$ applied per irrigation treatment.

\section{REGIONAL EVALUATIONS}

The objectives of this task are to determine the climatic and edaphic influences on plant community structure (cover, density, rooting

TABLE 1. Germination Summary for Plant Species on the Grand Junction Test Plot (May 18, 1981)(a)

\begin{tabular}{|c|c|c|c|c|}
\hline Species & $\begin{array}{c}\text { No. of } \\
\text { Individuals } \\
\text { Counted }\end{array}$ & $\begin{array}{c}\text { Mean } \\
\text { Density } \\
\left(\text { No. Indiv. } / \mathrm{m}^{2}\right)\end{array}$ & $\begin{array}{c}\% \text { Plot } \\
\text { Frequency(b) }\end{array}$ & $\begin{array}{c}\% \text { of Total } \\
\text { No. Individuals } \\
\text { Occurring } \\
\text { in One Plot(c) }\end{array}$ \\
\hline Agropyron spp.(d) & 491 & 43.8 & 62.5 & 9.2 \\
\hline Puccinelli lemmoni(d) & 148 & 13.2 & 32.1 & 10.1 \\
\hline Salsola kali & 90 & 8.0 & 42.9 & 4.4 \\
\hline Amaranthus retroflexus(d) & 67 & 6.0 & 29.5 & 7.5 \\
\hline Oryzopsis hymenoides(d) & 50 & 4.5 & 23.2 & 22.0 \\
\hline Kochia prostrata & 37 & 3.3 & 17.9 & 10.8 \\
\hline Grass spp. & 22 & 2.0 & 2.7 & 77.34 \\
\hline Other species(e) & 20 & 1.8 & 8.0 & 15.0 \\
\hline
\end{tabular}

(a) Total number of plots $=112$. Total number of individual plants counted $=925$. Plot size (standard Daubenmire frame) $=0.1 \mathrm{~m}^{2}$.

(b) Percent plot frequency equals the number of plots in which a species was present divided by the total number of plots (112).

(c) Percent of total number of individuals occurring on a plot equals maximum counts for a single plot divided by the total number of individuals for a given species.

(d) Seeded species.

(e) Seeded spp.: Sporobolus airoides, Hilaria jamesii, Sphaeralcea coccinea, and Atriplex sp. Invading spp.: Halogeton glomeratus, and Distichlis stricta and Chenopodiaceace spp. 
profile), provide necessary data to develop a predictive model for estimating revegetation potential, and provide data necessary for erosion modeling.

This year, 20 of the inactive uranium tailings sites were grouped, using a cluster analysis based on climatic data, into three general regions: the Colorado Plateau--Four Corners area (Grand Junction, Naturita, Slick Rock, Shiprock, Monument Valley, Tuba City, Mexican Hat and Green River); the west slope of the Colorado Rockies (Ambrosia Lake, Durango, Gunnison, Rifle and Baggs); and the Northern Great Plains (Belf ield, Bowman, Riverton and Spook). Soils and vegetation were then sampled in these general regions.

In each region, vegetative cover was sampled on soil types representative of those likely to be used as topsoil for a particular tailings pile. Soil units were chosen with the help of a soil scientist and local soil conservation service personnel. The criteria used in choosing soil types included extent (percent coverage of a county), depth, and texture. The actual location of sampling within a selected soil type depended upon accessibility, ownership and range condition. At a chosen sampling location, a line intercept method was used to estimate shrub and bunchgrass cover. Ten 50-m transects were designated in each area. Daubenmire plots were used to estimate grass and forb coverage and were placed at $10-m$ intervals along the 500-m transect. All cover measurements were categorized according to species. A surface soil sample was taken every $100 \mathrm{~m}$ for $\mathrm{pH}$ measurement. Soil cores, collected in 20-cmdepth increments, were taken at the beginning, middle and end points of the 500-m transect. The cores will be analyzed for texture, organic matter content, particle size, electrical conductivity and macronutrients.

Another major accomplishment of this task was the acquisition and compilation of published data needed for the modeling task and the field sampling effort. This included extracting information on location and climate from the Ford Bacon and Davis Engineering reports for each of the tailings piles, ordering topographic and land ownership maps for each of the regions sampled, and summarizing climatological data from the annual National Oceanic and Atmospheric Administration reports. Data on soils for regional sampling and erosion modeling was acquired from published soil surveys and from the Soil Conservation Service. The Plant Information Network (PIN), a data base developed for the U.S. Fish and Wildlife Service by Colorado State University, was used to provide preliminary information on the plants in each of the regions to be sampled. All relevant published data, as well as acquired reports on related research, were cataloged on a data-retrieve system.

\section{MODEL ING}

The objective of this task is to develop predictive models for determining the need for, and interaction among, proposed cover treatments. The functional role of vegetation and rock covers and how they relate to soil moisture changes are viewed as critical to the overall success of the integrated remedial action plan for each tailings site. During FY 1981, erosion and soil water models were examined for use on mill tailings. Appropriate models were chosen, and work was begun on adapting them to this project.

Erosion. Established models of soil erosion are being adapted for use at tailings sites. The FY 1981 work used data collected from the Grand Junction area and the tailings pile. Subsequent work is planned to verify the models using site-specific and regional data from other uranium mill tailings sites.

Two models were explored for possible use in estimating erosion due to overland water flow. The simplest model is the Universal Soil Loss Equation (USLE). It is an empirical equation that estimates long-term average annual soil loss. The USLE is easy and expedient to apply and can provide useful information; however, it does not account for the potentially catastrophic effects of extreme rainfall events. The Agricultural Runoff Management (ARM) Model is a more complex model. It simulates the hydrologic processes that convert precipitation to overland, subsurf ace, and ground water flow and the erosion of soil materials due to rain-fall impact and runoff.

A procedure for calculating the annual wind erosion from a tailings pile has been implemented. The procedure is based on the wind erosion equation developed by $W$. S. Chep $i 1$ and modified by $N$. P. Woodruff and T. H. Siddoway. The model is based on wind tunnel and agricultural field measurements. Meteorological parameters, and parameters describing the physical properties of the tailings site, are used as input data. Soil loss by wind in (tons/acre)/year is the output.

Soil Water Dynamics. Rock and vegetation covers have been proposed for surface stabilization of inactive uranium mill tailings piles. To the extent that rock covers impede runoff and restrict plant growth and evaporation from the soil surface, they may result 
in increased soil (tailings) moisture. Elevated moisture content $c$ an be beneficial by reducing pore space and thereby suppressing radon release. Excess moisture, however, may be detrimental if it promotes leaching and drainage of contaminants through the tailings to ground water. Differences in local climates and soil properties at the tailings disposal sites, as well as engineering design criteria, require an integrated approach to any proposed remedial action. Long-term functional stability $c$ an be insured only if all the elements that affect the success of a remedial action design are accounted for.

A partially saturated flow model is used to analyze a representative uranium mill tailings pile under different cover treatments. The modeling effort provided a qualitative assessment of the effects of vegetation and rock covers on soil moisture flow. Also, field studies were conducted to evaluate evaporation rates from soils having a variety of rock and vegetative covers.

Model results indicate that a vegetated cover system will result in a relatively constant moisture storage in the tailings pile. A 50$\mathrm{cm}$-thick rock cover, on the other hand, may result in a significant increase in moisture storage and drainage from the tailings pile. These results suggest that vegetation (and/or thinner rip-rap covers), engineered drainage, or liner systems may be necessary to prevent drainage and subsequent leaching of contaminant to the ground-water system.

To investigate evaporation from rock covers experimentally, a series of weighing lysimeters filled with Ritzville silt loam was constructed. Following an initial watering with the equivalent of $5 \mathrm{~cm}$ of precipitation, eva- porative water loss in the presence of various aggregate covers (sand, pea and coarse gravel applied to the surface at a rate of $22.4 \mathrm{~kg} / \mathrm{m}^{2}$, or $1.9-\mathrm{cm}$ thick) was compared with the evaporative loss from bare soil. As the surfaces of the sand treatments dried, evaporation effectively ceased. The gravel treatments permitted evaporation, albeit at a lower rate than bare soil. Comparisons of coarse gravel applied at rates of 22.4 (1.9), 44.8 $(3.8), 67.3(5.7)$, and $89.7 \mathrm{~kg} / \mathrm{m}^{2}(7.6 \mathrm{~cm})$ showed that bare soil lost water much more rapidly than did the rock cover treatments during the first 7 days following watering. Beyond 7 days, however, the rate of evaporation from bare soil declined relative to the rates of evaporation from the rock cover treatments. A dry surface layer was formed during this period as well. At 14 days and beyond, little difference in the cumulative water losses from bare soil compared to the rock cover treatments was observed.

These results indicate that for the coarse aggregate size and treatment rates employed, the effect of rock cover on evaporation is most pronounced shortly after precipitation; thus, when rock covers are employed, the frequency of precipitation events may be the major factor determining the potential for increased soil moisture content. Any consequent increase in potential for leaching of materials from the tailings will be linked to frequency of precipitation as well. In addition, since the rates of application of aggregates used in this study have been shown to permit the establishment of vegetation, it may be possible to combine rock cover with vegetative covers to provide effective surface stabilization. Transpiration by vegetation will also serve to reduce the potential for increased subsurface moisture content. 
Alaskan Resource Research 



\section{ALASKAN RESOURCE RESEARCH}

\section{- Ecological Investigation of Alaskan Resource Development}

Principal Investigator: W. C. Hanson

Associate Investigator: L. E. Eberhardt

Ecological studies of the consequences of resource development in northern Alaska began in 1974 as part of the broader mission of the Energy Research and Development Administration. The studies represent an extension of environmental programs conducted for the petroleum industry at Prudhoe Bay from 1971 to 1973. They have been continued, under the Department of Energy, to assess the true environmental cost of resource development in a previously undeveloped region of great national interest. Emphasis has been placed on collecting baseline data on ecosystems that are or soon will be affected by petroleum resource extraction and transportation.

Quantitative information is currently being obtained on small-mammal and bird populations in disturbed and control habitats to determine short-term impacts of construction, long-term impacts of operations, and mitigative procedures that may apply to future developments and to other technologies and environments.

A smaller portion of this work represents continuation of radiological monitoring, which has been continued since 1959 where it was commenced by the Atomic Energy Commission. 



\title{
- Ecological Investigation of Alaskan Resource Development
}

\author{
Principal Investigator: W. C. Hanson \\ Associate Investigator: L. E. Eberhardt
}

The objective of this research is to provide an integrated program for the definition of ecological consequences of resource developments in northern Alaska. The qualitative and quantitative results obtained describe the environmental costs incurred by petroleum resource extraction and transportation, and the interaction of wildlife populations with industrial activities. Information is presented on: affected populations of arctic foxes, small mammals, and tundra-nesting birds along the TransAlaska pipeline and haul road; field studies on the nitrogen fixation patterns of lichens; and on amounts of radionuclides from worldwide fallout in the lichen-caribou-Eskimo food chain.

\section{ARCTIC FOX STUDIES}

Personnel at the University of Alaska and Alaska Division of Public Health (E. Follmann and $D$. Ritter, respectively) are currently determining the incidence of rabies, canine distemper, and canine hepatit is in 326 arctic fox (Alopex lagopus) heads collected from trappers at Barrow, Alaska, from 1977 to 1980. A number of animals have been examined; however, reductions in manpower at the Disease Laboratory have extended the period required for analysis. Disease incidence will be compared to animal age and population density. The results will be useful in understanding the epidemiology of these diseases in northern regions. Rabies is enzootic in arctic fox populations and becomes a significant human health hazard in years of epizootics. A number of Prudhoe Bay oil field personnel are exposed to and treated for rabies in years when this disease is epizootic. This problem is compounded by the concentrations of foxes at Prudhoe Bay that are attracted to garbage food sources.

\section{SMALL-MAMMAL STUDIES}

A second season of radio-telemetry studies of the singing vole (Microtus gregalis) was conducted on the Franklin Bluffs study plot.

The purposes of this investigation were to: 1) evaluate the effects of the Trans-Alaska pipeline on small-marmal movements, 2) gather information on the ecology of small mammals of this region, and 3 ) evaluate radio-telemetry techniques for future tracking of small manmals during the winter when extensive oil and gas exploration activities disturb large areas of small-mammal habitat. Twenty-two voles were radio-collared during June and July. Marked voles heavily used the fertilized and revegetated areas along the pipeline.
Revegetated areas directly above the buried pipe "green-up" early in the season, presumably due to heat radiated from the pipe, and vole movement to and use of these green areas was extensive. Unvegetated gravel areas on the pipe pad appeared to restrict the daily movement of voles; however, voles did cross these open areas during dispersal. Dispersal movements of up to $775 \mathrm{~m}$ were observed shortly after snow melt. Five of $22(23 \%)$ voles radio-collared during 1981 were predated. Analysis of vole home-range data for the 1981 field season is underway. The home-range size for voles tracked in $1980(N=9)$ was $0.24 \pm$ 0.19 ha. Females had smaller home ranges $(0.11+0.08 \mathrm{ha} ; \mathrm{N}=5)$ than did males $(0.39$ \pm 0.18 ha; $N=4$ ). Cont inuous monitoring of eight voles for periods of 3 to 12 days during 1981 showed that they were active an average of $59 \%$ (range: $44 \%$ to $73 \%$ ) of the time. Voles were generally active throughout a 24-hour period, although hot weather tended to reduce activity.

\section{BIRD STUDIES}

Field studies of tundra-nesting birds in the vicinity of the Trans-Alaska pipeline and haul road began on May 28, at which time snow cover was complete at both the Franklin Bluffs (FB) and Trans-Alaska Pipeline Mile 12 (TAP/M12) study sites. Snow cover phenology this year at the TAP/M12 study site was about 5 days earlier than in 1980 and 14 days later than in 1979; notwithstanding, the first full clutch of a Lapland longspur (earliest breeding bird) in 1979 it was June 6 ; in 1980 was June 12; and in 1981 it was June 4 . This illustrates the adaptation of tundra-nesting birds to stressful environmental conditions.

The TAP/M12 site was altered this year in order to evaluate bird nesting densities prior 
to the proposed construction of the AlaskanCarradian natural gas pipeline. The study plot now is 110 ha in area, approximately rectan1ar in shape, with the recent1y added 27-ha strip in the northeast corner that intercepts the gas pipeline alignment (Figure 1).

Nesting densities (nests per hectare) on the east (upwind of prevailing direction) side of the study area were $28 \%$ greater than on the west (downwind) side of the area, which was consistent with 1979 and 1980 observations.

This illustrates the continuing effect of the Trans-Alaska pipeline on nesting phenomena of tundra-nesting birds.
The west side of the area is subject to an unusual accumulation of snow in a $250-m$ wide corridor along the aboveground pipeline as a result of the "snow fence effect," and to interdiction of normal runoff patterns of snowmelt by the pipeline access roads and pipe pads. During the past three years of study, we have documented a progressive displacement of nesting birds away from the flooded west side of the study plot. Only some of the later-nesting species such as northern phalaropes and the second, "late wave," of female pectoral sandpipers can utilize the habitat close to the pipeline. Increasing numbers of northern phalaropes have been using the TPA/ M12 site, which verifies the transition to wetter habitats (Table 1).

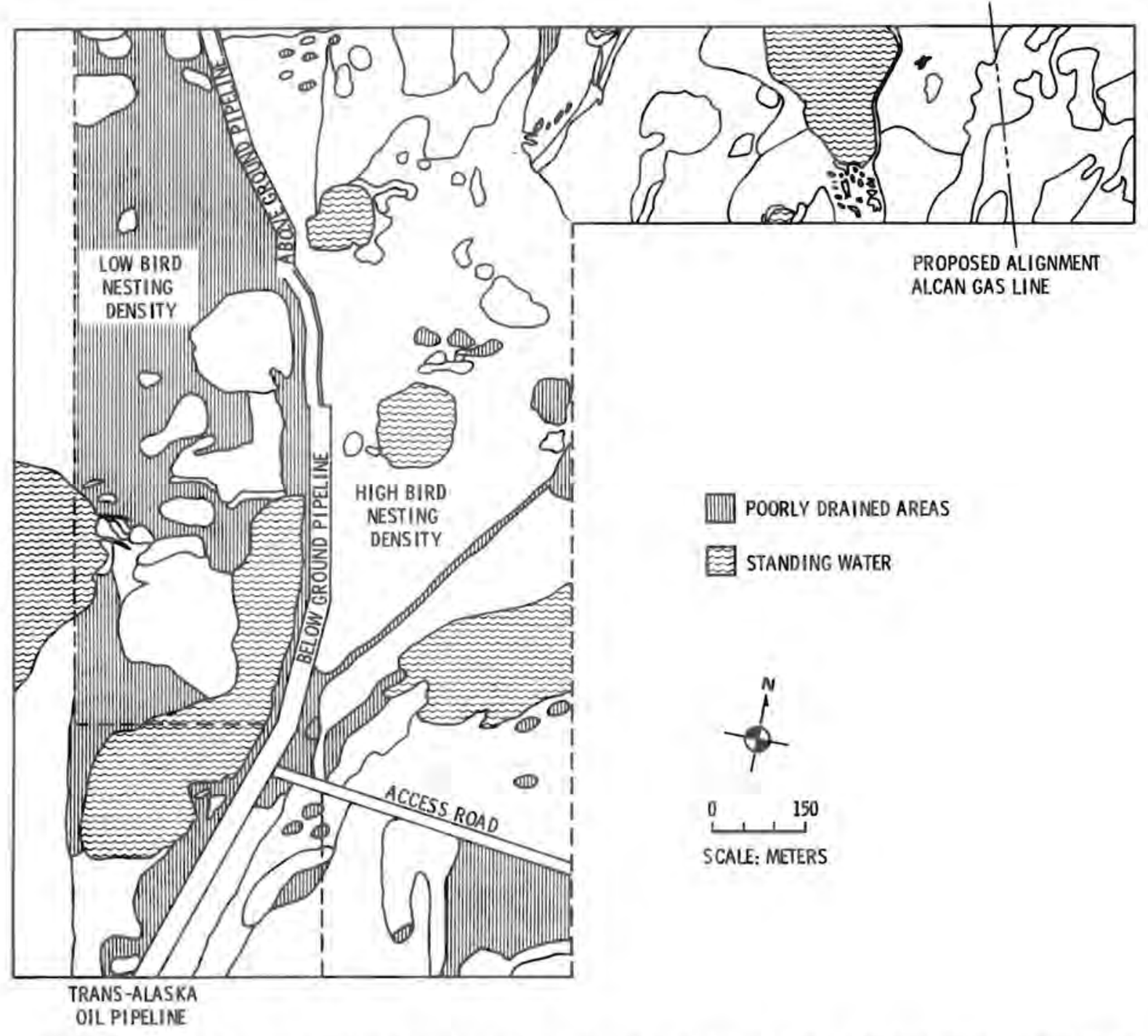

FIGURE 1. Trans-Alaska Pipeline Mile 12 Bird Study Plot, Altered from the 1980 Configuration to Allow an Evaluation of Bird Densities Prior to the Proposed Construction of the Alaskan-Canadian Natural Gas Pipeline 
TABLE 1. Nesting Densities of Breeding Birds During the Period 1979 to 1981 at Trans Alaska Pipeline Mile 12 Study Site, Northern Alaksa

\begin{tabular}{|c|c|c|c|}
\hline \multirow[b]{2}{*}{ Species } & \multicolumn{3}{|c|}{ Nests per 100 ha } \\
\hline & 1979 & 1980 & 1981 \\
\hline Arctic Loon & 3 & 3 & 3 \\
\hline American Golden Plover & 3 & 2 & 2 \\
\hline Pectoral Sandpiper & 28 & 37 & 24 \\
\hline Dunlin & 3 & 3 & 3 \\
\hline Semipalmated Sandpiper & 20 & 35 & 20 \\
\hline Northern Phalarope & 3 & 10 & 17 \\
\hline Lapland Longspur & 27 & 35 & 36 \\
\hline Other & 4 & 5 & 9 \\
\hline Total & 88 & 130 & 114 \\
\hline
\end{tabular}

At Franklin Bluffs, the overall population density of breeding birds was $59 \%$ and $57 \%$ greater than those observed in 1979 and 1980, respectively. Eight of the 13 most common nesting species occurred in the highest densities recorded in six years of study, and only buff-breasted sandpipers were below the six-year mean. The steady increases in nesting densities of major species (Table 2) from 1976 to 1981 suggest that the tundra bird populations may be reestablishing territories in areas disturbed in 1975 and 1976 by pipeline construction-related activities. Northern phalaropes were found in modest numbers nesting in habitats that have been altered by impounded drainage behind the haul road. Conversely, the deposition of wind-blown dust on the downwind (west) side of the haul road has apparently reduced nesting densities in the $\sim 15$ ha affected by dust-fall, as indicated by contrasting densities of one nest per 3.75 ha in the dust-fall area compared to one nest per 2.05 ha in the rest of the study area.

Nesting success was substantially lower this year than last, declining to $37 \%$ at TAP/M12 and to $28 \%$ at FB. Major losses were to a red fox and ravens at $F B$ and to an arctic fox and jaegers that foraged over the TAP/M12 site. The lower production was reflected in numbers of birds banded. Totals of 141 and 472 new bands were applied at FB and TAP/M12, respectively. Six previously banded birds were recaptured at FB and 42 were recaptured at TAP/ M12, providing additional data on nest site tenacity in five species. Trapping of adult and fledging Lapland longspurs by use of special traps provided better documentation of territorial phenomena and provided the first firm evidence of polygamy in that species.
TABLE 2. Nesting Densities of Breeding Birds During the Period 1976 to 1981 at Franklin Bluffs Study Site, Northern Alaska

\begin{tabular}{|c|c|c|c|c|c|c|}
\hline \multirow[b]{2}{*}{ Species } & \multicolumn{6}{|c|}{ Nests per 100 ha } \\
\hline & \multirow[t]{2}{*}{1976} & \multirow[t]{2}{*}{1977} & \multirow[t]{2}{*}{1978} & \multirow[t]{2}{*}{1979} & \multirow[t]{2}{*}{1980} & 1981 \\
\hline American & & & & & & \\
\hline Golden Plover & 5 & 5 & 7 & 11 & 13 & 12 \\
\hline $\begin{array}{l}\text { Pectoral } \\
\text { Sandpiper }\end{array}$ & 0 & 8 & 2 & 1 & 8 & 8 \\
\hline Buff-Breasted & & & & & & \\
\hline Sandpiper & 1 & 6 & 10 & 5 & 7 & 5 \\
\hline Long-Billed & & & & & & \\
\hline Dowitcher & 2 & 2 & 0 & 0 & 0 & 0 \\
\hline Semipalmated & & & & & & \\
\hline Sandpiper & 2 & 6 & 2 & 2 & 1 & 2 \\
\hline Redpoll & 2 & 1 & 0 & 1 & 0 & 5 \\
\hline Lapland & & & & & & \\
\hline Longspur & 8 & 14 & 18 & 26 & 25 & 33 \\
\hline Other & 2 & 3 & 12 & 16 & 17 & 14 \\
\hline Total & 22 & 45 & 51 & 62 & 71 & 79 \\
\hline
\end{tabular}

\section{LICHEN STUDIES}

Arizona State University subcontractors (Dr. T. H. Nash, Dr. T. J. Moser and Ms. A. 01 afsen) continued field and laboratory studies of lichen communities of Anaktuvuk Pass. The nitrogen fixation and photosynthetic patterns of lichens (Peltigera canina and Stereocaulon tomentosum) were studied for eight to ten 24-hour periods between mid-June and midSeptember. Approximately 2000 samples were collected for laboratory analysis. These studies are important because they define the critical parameters in biological nitrogen fixation in arctic ecosystems and detemine the implications of an ecosystem's sensitivity to sulfur dioxide. These data will compliment ongoing studies that have shown that atmospheric concentrations of 0.5 to $1.0 \mathrm{ppm}$ $\mathrm{SO}_{2}$ are sufficient to interdict photosynthetic capability of tundra lichens. Lichens are a critical winter food of caribou and are an important source of useable nitrogen to arctic ecosystems.

\section{RADIATION ECOLOGY STUDIES}

The long-term investigation of worldwide fallout of strontium-90 and cesium-137 in the $1 i-$ chen-caribou-Eskimo food chain in Anaktuvuk 
Pass was summarized for the period 1962 to 1979 now that ${ }^{137} C_{S}$ body burden measurements of the people have been terminated. The information on ${ }^{137} \mathrm{Cs}$ explained the structure and function of the cesium concentration process and described the impacts of ecological 3 cultural, and political factors upon the $137 \mathrm{Cs}$ body burdens and resultant radiation doses to the Eskimos. Maximum ${ }^{137} \mathrm{Cs}$ concentrations of $\sim 20$ nanocuries ( $\mathrm{nCi}$ ) per $\mathrm{kg}$ body weight occurred in 1964 and decreased to $\sim 0.5 \mathrm{nCi} / \mathrm{kg}$ in 1979, largely because of cultural and political factors. Radiation doses from $137 \mathrm{Cs}$ body burdens during the study period ranged from $60 \mathrm{mrad} /$ year in 1962 to $-140 \mathrm{mrad} /$ year between 1962 and 1964 and decreased to $8 \mathrm{mrad} /$ year in 1979. Tracer kinetics of $137 \mathrm{Cs}$ provided unusual opportunities to calculate: 1) half-times of this radionuclide in lichens, caribou, wolves and Eskimos; 2) consumption rates of lichens by caribou on winter ranges; 3) consumption rates of caribou meat by Eskimos; and 4) provided insight into the cultural change of the Anaktuvuk Pass people.

Strontium-90 concentrations in skeletons of Anaktuvuk Pass residents during 1954 through 1979 were predicted from two models based on the Sr kinetics in human bone and the estimated annual $90 \mathrm{Sr}$ ingestion rates via caribou meat, which were provided by the ${ }^{137}$ Cs kinetics data. Predicted skeletal burdens of adult Eskimos gradually increased through 1961 and then rapidly achieved maximal values between 1964 and 1966. This increase reflects fall-out ${ }^{90} \mathrm{Sr}$ levels in caribou meat that contributed $80 \%$ to $97 \%$ of dietary $90 \mathrm{Sr}$ intake. Concentrations of $90 \mathrm{Sr}$ in male Eskimo bone samples were similar using either model. Predicted values in vertebrae of adult Eskimo males were slightly lower than values reported in New York City adults until 1970, when $90 \mathrm{Sr}$ in Eskimo samples declined by $9 \%$ per year, while samples from adults in New York City and San Francisco declined by $6 \%$ and $5 \%$, respectively. Predicted skeletal burdens in Anaktuvuk Pass residents born in 1954 and 1959 were maximal in 1971 and 1974, respectively; concentrations in children born in 1964 were still increasing in 1979 but had achieved a lower level than older-age cohorts. Est imated radiation dose rates to adult skeletons during 1964 to 1966 were 13 to $15 \mathrm{mrad} /$ year based on predicted vertebrae $90 \mathrm{Sr}$ concentrations.

Those dose rates were $1 \%$ of recommended International Commission on Radiological Protection (ICRP) limits for general populations. Papers summarizing our research have been accepted for publication in Health Physics.

A series of vegetation samples obtained from the Western Arctic Caribou Herd summer range between 1964 to 1971 were retrieved from the sample library and submitted for transuranium radionuclide analyses. Sample analyses will provide a series of concentration ratios for plutonium-238, -239 , and -240 and americium141 in arctic ecosystems during a period of substantial worldwide fallout deposition. 


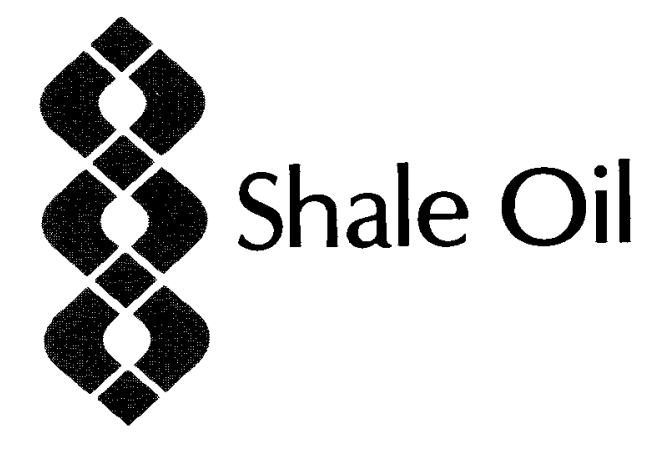





\section{SHALE OIL}

\section{- Terrestrial Effects of Oil Shale Development}

Vast domestic resources of oil shale may provide a long-term alternative to petroleum-derived fuel products. Methods proposed for obtaining shale oil from its deposits range from conventional mining and aboveground retorting technologies to in situ retorting. The technological and economic aspects of this wide range of options are currently under intensive study. The environmental impacts must also be assessed because questions of siting, control technology, licensing and regulation can strongly affect the best production strategy.

Three major segments of the aboveground shale oil production cycle may potentially produce environmental consequences. These include mining of the shale, extraction of the shale oil, and disposal of processed shale. In the mining process, aquifer disruption, runoff, and movement of raw shale residuals through the soil and substrata to ground waters may affect streams and rivers. During the extraction cycle (crushing, retorting and refining), the major impact will result from gaseous emissions and liquid effluents containing organic, macro-ion, and trace metal residues. Disposal of retorted shale presents problems in loss of recreation land, in reclamation of land occupied by retorted shale, and in environmental and human exposure resulting from resuspension of particulates and leaching of pollutants to ground and surface waters. The nature of the shale and the use of pyrolytic methods can lead to the formation of reduced sulfur and the solubilization of other chemical species, such as trace metals and heterocyclic nitrogen components, which might result in environmental problems not ordinarily encountered in other energy industries.

The laboratory-wide PNL program currently focuses on the chemical characterization of effluents (see PNL-4100, Part 4, Physical Sciences), the potential human toxicity of effluents (see PNL 4100, Part 1, Biomedical Sciences), and the chemical and microbiological processes governing the fate, mobilization and biological availability and effects of inorganic and organic residuals in wastes disposed to the ground (this report). Supporting research on the feasibility of revegetation in arid climates is described in the Land Use section of this report. Together, these programs provide a basis for assessment of the potential terrestrial effects of waste disposal and for viable restoration of shale lands. 



\title{
- Terrestrial Effects of Oil Shale Development
}

\author{
Principal Investigator: R. E. Wildung
}

Associate Investigators: T. R. Garland, J. M. Zachara, R. G. Riley, J. E. Rogers, E. A. Jenne, G. Gee, A. Felmy, L. L. Ames, D. A. Cataldo, S. W. Li and K. M. McFadden

The potential development of the oil shale industry requires the concomitant development of methodology to evaluate and ameliorate the environmental impact of ground disposal of wastes. Therefore, this research program has emphasized 1) laboratory and field studies to determine the mineralogical, chemical and microbiological processes controlling the long-term composition of leachates from raw shale, retorted shale, and retort waters; 2) the hydrologic factors governing transport to surface and ground waters; 3) leachate attenuation in substrates and retort water and leachate treatments/barriers to ameliorate impact on water quality; 4) validation and modeling of the chemical reactions and hydrologic transport of inorganic and organic residuals to ground and surface waters at modified in situ and aboveground retorting sites; and 5) aquatic toxicity, mutagenicity, and plant availability of organic and inorganic residuals mobilized with time and weathering.

Field studies on movement of trace metals and organic residuals in retorted shale have been underway since 1977 at the Department of Energy's Rifle Oil Shale Facility at Anvil Points, Colorado; at the Occidental Oil Shale Corporation Site at Logan Wash, Colorado; and at Federal Lease Tracts C-a and $\mathrm{C}-\mathrm{b}$ in the Piceance Creek Basin, Colorado. The studies have been conducted in conjunction with the United States Geological Survey and Colorado State University. The results of these studies are being used to validate laboratory and computer models that simulate the migration of residuals to surface water and alluvial aquifers. The studies have already led to new concepts about the nature and longterm impacts of oil-shale leachates. Moreover, the findings are providing a sound technical basis for designing disposal methods.

The results of these studies are currently being used by state and federal agencies in the permitting and regulatory process and by industry in the design and construction of disposal sites. The research program complements current DOE programs in risk assessment and oil shale development, namely, the Health and Environmental Effects Document, the Oil Shale Technology Assessment Document, the Oil Shale Environmental Development Plan, the Oil Shale Commercialization Environmental Readiness Document, and the Task Force on Oil Shale Development. The research effort also contributed to several studies by other agencies and industry, including a study by the National Academy of Sciences on how mining and the extraction of oil shale redistribute accessory minerals.

\section{WASTE PROCESSES CONTROLLING LEACHATE} CHEMISTRY

This program defines the long-term hydrological and chemical processes that affect the chemical composition of leachates from raw and retorted shales disposed of in the ground, and the movement of leachates to ground and surface waters. The discussion below highlights progress over the past year in laboratory and field studies to establish controlling processes and provide a basis for solid waste management.

Raw Shales--Laboratory Studies. Laboratory batch and column leaching studies were performed with Tract $\mathrm{C}-\mathrm{a}$ raw shale to evaluate the quantity and composition of solubles potentially released from raw shale during storage and disposal. Raw shale, which was removed from Rio Blanco Dil Shale Company's Retort 0 during rubbilization, was sampled with respect to pile depth and retort blast sequence. This material was used to establish field lysimeters (described below) to examine leachate chemistry.

Batch extractions were used to identify the total quantity of solubles from selected depths in the lysimeter pile as influenced by blast sequence and particle size. These materials were found to be relatively homogeneous throughout, releasing from 7.3 to $10.7 \mathrm{mg} / \mathrm{g}$ of soluble inorganics. Prominent 
species in these extractions included $\mathrm{Ca}, \mathrm{Mg}$, $\mathrm{Na}, \mathrm{K}, \mathrm{Sr}, \mathrm{SO}_{4}, \mathrm{NO}_{3}, \mathrm{HCO}_{3}$, and $\mathrm{Cl}$. Field leaching processes were simulated in the laboratory using column studies. Percolation of distilled water through these columns produced initially saline leachates (conductivity 16.5 to $25.7 \mu \mathrm{mho} / \mathrm{cm}$ with elevated levels of macroions ( $\mathrm{Na}, \mathrm{K}, \mathrm{Mg}, \mathrm{SO}_{4}, \mathrm{NO}_{3}, \mathrm{~S}_{2} \mathrm{O}_{3}$ ) and some $\mathrm{mi-}$ nor elements ( $\mathrm{Al}, \mathrm{Cr}, \mathrm{Ni}, \mathrm{Mn}, \mathrm{Pb}$, and $\mathrm{Mo}$ ) relative to natural waters of the area. This pulse of solubles diminished rapidly with leaching. Concentrations of most species reached equilibrium after 1.50 column volumes ( $v / v o$ ) at levels in excess of deep tract ground waters in contact with these same strata.

Raw Shales - Field Lysimeter Studies. Raw shale lysimeters that allowed collection of leachates from three depths of shale were installed in the fall of 1980 at lease Tracts $\mathrm{C}-\mathrm{a}$ and $\mathrm{C}-\mathrm{b}$. The design, installation, and maintenance was under the guidance of the United States Geological Survey and Colorado State University. The coarse texture of the raw shale allowed leachate to be collected immediately after each major precipitation event from March through August. Although significant differences exist in the total salt content of leachates from $C-a$ and $C-b$ shale (maximum conductivities: 32,000 and $7500 \mu \mathrm{mho} / \mathrm{cm}$, respectively), with the exceptions of $\mathrm{SO}_{4}$ and total $\mathrm{P}, \mathrm{Mg}, \mathrm{Cl}$ and $\mathrm{Mo}$, the chemical composi$t$ ion of the two leachates (at all depths) is remarkably similar. This similarity is especially important, because the raw shale for $C-a$ and $C-b$ came from different stratigraphic zones.

Selected chemical species found in the shale leachates at a common depth are compared in Table 1. The difference in conductivities of the leachates from $C-a$ and $C-b$ shales is due

TABLE 1. Comparison of Chemical Constituents in Leachate from Raw Oil Shale from Tracts C-a and C-b

\begin{tabular}{|c|c|c|}
\hline \multirow{2}{*}{$\begin{array}{l}\text { Chemical } \\
\text { Species }\end{array}$} & \multicolumn{2}{|c|}{ Leachate, $\mathrm{mg} / \mathrm{ml}$} \\
\hline & Tract C-a & Tract C-b \\
\hline $\mathrm{Na}$ & $47-56$ & $43-50$ \\
\hline $\mathrm{Ca}$ & $7-12$ & $6-9$ \\
\hline $\mathrm{Mg}$ & $210-280$ & $5-8$ \\
\hline $\mathbf{P}$ & $0.093-0.20$ & 0.004 \\
\hline Mo & 0.0005 & $0.05-0.11$ \\
\hline $\mathrm{Cl}$ & $9.3-11$ & $0.26-0.43$ \\
\hline $\mathrm{NO}_{3}$ & $19-29$ & $1.2-1.8$ \\
\hline $\mathrm{SO}_{4}$ & $260-380$ & $32-41$ \\
\hline
\end{tabular}

due to the presence of high levels of $\mathrm{MgSO}_{4}$ in the $\mathrm{C}-\mathrm{a}$ leachates. The $\mathrm{C}-\mathrm{a}$ shale leachates also have 30 to 40 times more soluble $P$ and $\mathrm{Cl}$ and about 15 times more $\mathrm{NO}_{3}$. The $\mathrm{C}-\mathrm{b}$ shale leachates contain soluble Mo at levels greater than a hundred $t$ imes that of the $\mathrm{C}-\mathrm{a}$ shale leachates. These differences in solution composition probably reflect differences in specific minerals or mineral assembleges in the two oil shales used in the construction of the lysimeters. The level of soluble $\mathrm{NO}_{3}$ in both shale leachates is sufficiently high for concern as a potential pollutant of ground or surface water if proper siting of the raw shale storage areas or other engineered containment of the leachates are not considered during commercial development.

\section{INTERACTION OF RETORTED SHALE LEACHATES WITH LINERS AND SUBSTRATA}

Upon commercialization, surface retorted shale will be disposed of in large quantities to engineered landfills in canyons, depressions, or mesa tops. Design parameters for commercial-scale disposal sites have not been made final; however, all soil materials will likely be removed and stockpiled for use in revegetation, and the embankments probably will be placed on alluvial subsoil materials or directly in bedrock. Some form of liner material will be required to prevent the release of leachates or surface runoff that may be produced. In the event of a leachate release, the resulting environmental impacts will be modified as soluble retorted shale components contact and interact with substrata underlying and surrounding the disposal sites. To determine what these modifying factors might be, laboratory studies were initiated to identify precipitation, adsorption/ion exchange, and other mechanisms altering retorted shale leachate composition in passage through potential liner, soil, subsoil, or bedrock materials. Studies over the past year have focused upon the interaction of Paraho retorted shale leachates with soil and subsoil material taken from the DOE Rifle 0il Shale Facility at Anvil Points.

A homogeneous shale leachate in sufficient quantity was made by batch equilibration of Paraho retorted shale with distilled-deionized water. The leachate was filter-sterilized $(0.22 \mathrm{\mu m})$ and passed through columns of calcareous, alluvial soil and subsoil at a flow rate of approximately one pore or void volume per week. Generally, leachate was added to the columns until the concentrations of most dissolved species equilibrated in the eluants or until six void volumes had been collected. 
The resulting column eluants were analyzed for $\mathrm{pH}$, conductivity, Eh, organic and inorganic carbon, major and minor cations and anions, and trace elements. Selected results of passing one column volume of retorted shale leachate through soil and subsoil are summarized in Table 2. Both soil and subsoil were effective in reducing the alkaline $\mathrm{pH}$ of leachate. Sodium in the retorted shale leachate displaced exchangeable $\mathrm{Ca}$ and $\mathrm{Mg}$ and resulted in higher levels of $\mathrm{Mg}$ in the column eluates and precipitation of $\mathrm{CaCO}_{3}$ in the column, which reduced permeability with time. The anionic reduced sulfur species, $\mathrm{S}_{2} \mathrm{O}_{3}$ and $\mathrm{SCN}$, and Mo (present as $\mathrm{MoO}_{4}$ ) were mobile through soil and subsoil. (These species are elevated in concentration relative to soil and natural waters of the Colorado oil shale region.) In contrast, $F$ concentrations decreased, possibly by precipitation of $F$ as flourite, to $\mathrm{CaF}_{2}$. Boron and some alkali metals ( $L i$ and $K$ ) were attenuated by soil ion exchange, fixation, and adsorption processes.

These studies indicate that retorted shale leachates change in composition as they pass through soils and subsoil. Liners and substrata can attenuate leachates and thus

TABLE 2 Effects of Interaction with Soil in Retorted Shale Leachate

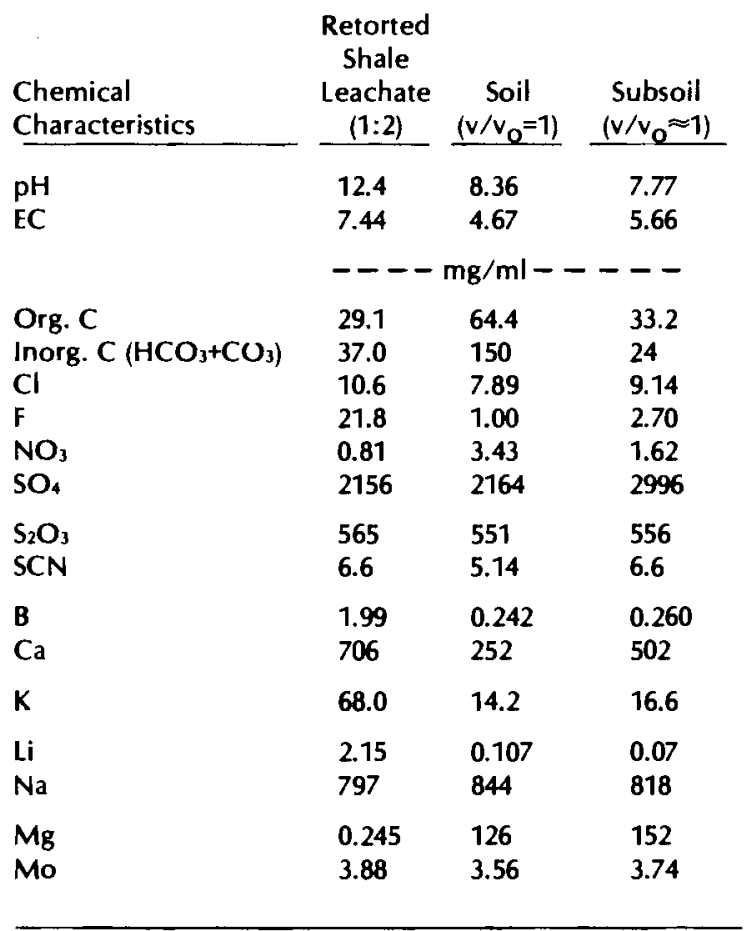

reduce the environmental impact of leachate releases. The degree to which liners and soils satisfy environmental controls for oil shale disposal sites still must be evaluated.

In FY 1982, the research program will be extended to include interaction of retorted shale leachates with prospective liner materials and substrata (Wasatch and Uinta formations) from proposed disposal sites in the Piceance Creek Basin.

\section{HYDROLOGIC PROCESSES CONTROLLING LEACHATE MOVEMENT}

In FY 1981, the hydrology of a model pile was simulated and the annual water balances of lightly and heavily compacted Paraho shale piles were compared. The modeling assumed that the pile was drained after an initial saturation period. Water movement was simulated at a clay liner located at the bottom of a $30-m$ pile that was subjected to typical climate conditions for Rifle, Colorado, in 1976.

The hydrology of a retorted oil shale pile was simulated for several test conditions using a one-dimensional, unsaturated flow model--UNSAT10. Available literature provided initial data necessary to describe the hydrologic properties of the oil shale under several compaction conditions. These properties included the water release (drainage) characteristic and the unsaturated conductivity for the retorted Paraho shale. Subroutines that were developed specifically for hydrologic characterization include HYDRAK, EXTEND, and POLYFIT. These subroutines provide hydrologic data sets that allow for computation of infiltration, drainage, and evaporation from the oil shale over the entire range of water contents from air-dry to saturation. The extension of data and computations into the air dry range was deemed necessary to adequately describe conditions existing near the pile surface during summer months in a semi-arid environment.

Climatic data, including rainfall, wind speed, and air temperatures, were obtained from weather records kept at $\mathrm{R}$ ifle, Colorado. Potential evapotranspiration (PET) was calculated by the Penman method for the Anvil Points site, and the subrout ine FAOPET was used to input the data into the unsaturated flow model. The model used hourly factors to distribute the PET over each day. Bare surface conditions have been simulated in the test runs made to date. The model also has the capability to simulate plant evaporation and root uptake of water. 
Water content plotted as a function of depth and time indicate that, for the shale properties and climatic conditions tested, the majority of the changes in water content occur in the top few meters of the shale pile. No drainage occurred from the 30-m test pile during the simulation period of one year, even though the water profile was taken to be initially at equilibrium with a water table present at $30 \mathrm{~m}$. Under conditions of no plant uptake, water storage increases significantly in the profile but, because the water capacity is sufficiently large, the water is stored near the surface and is removed by subsequent evaporation mechanisms. Optimal conditions for surface infiltration (snowmelt, reduced PET), which are known to occur in the spring and may markedly affect water movement, were not considered.

Cases with and without a clay liner near the bottom of the pile were tested. Seepage from the pile was not predicted in either case. Test comparisons used to evaluate the effects of compaction on the annual water balance of the retorted shale pile indicated that water storage was reduced approximately $25 \%$ as the density increased from $1.20 \mathrm{~g} / \mathrm{cm}^{3}$ to $1.55 \mathrm{~g} /$ $\mathrm{cm}^{3}$. The more compacted shale also exhibited the greatest water evaporation. This is because less water drains through the compacted material, leaving more water close to the surface. Hence, the soil surface's higher water content lends itse if to evaporation.

A liner at the bottom of the pile had no effect on drainage, because the pile was simulated as an initially drained pile. Moreover, although the annual water balance showed a net increase in storage, the water storage capacity in the pile at the surface was sufficiently large to prevent any significant downward movement of the stored water.

In Fy 1982, the models will incorporate laboratory-measured characteristics for Paraho and Lurgi spent shale, and the model capabilities will be extended to two-dimensional analysis. The incorporation of a plant uptake term will also be evaluated.

\section{SOURCE AND BEHAVIOR OF ORGANIC SUBSTANCES}

The following investigations encompass the behavior of organic and inorganic substances that might enter the environment as a result of oil shale production.

Source and Distribution of Alkylpyridines. The DOE Rifle Oil Shale Facility at Anvil Points, Colorado, has been in operation for almost 40 years. To identify changes that this facility may have brought about in the waters underlying the site, samples of surface waters, ground waters and subsoils were collected in the adjacent West Sharrard Drainage in May 1979 for chemical analysis. The samples consisted of 1) ground waters collected from wells located above and below the oil shale disposal area, 2) seeps below the disposal pile, and 3) surface waters collected from the stream at locations above and below the disposal area. Subsoil core samples were obtained at selected levels during the installation of new alluvial water wells.

Seeps and alluvial ground waters downstream of the retorted shale disposal pile contained more total dissolved organic carbon than waters collected upstream. Water from one well and one seep below the retorted shale pile had an odor similar to that of shale oil and retort water; however, none of the well water samples contained detectable levels of aromatic hydrocarbons, phenols or carboxylic acids. Solvent extracts of the well water that contained the odor, and the surface seep, were examined further using a combination of infrared and gas chromatographic techniques. Alkylpyridines, a group of aromatic nitrogencontaining organic bases, were detected in both samples.

Total alkylpyridine concentrations in water discharged from the seep and in water from the well were 30.8 and $4.1 \mathrm{\mu g} / \mathrm{ml}$, respectively. The surface stream waters at locations below the seep discharge also contained trace levels of alkylpyridines $(0.1$ to $0.2 \mathrm{\mu g} / \mathrm{ml})$, which are most likely due to dilution of the seep discharge. Alkylpyridines were not detected $(<0.1$ to $0.2 \mu \mathrm{g} / \mathrm{ml})$ in a sample of surface discharge; however, alkylpyridines were detected (2.3 to $55.1 \mathrm{\mu g} / \mathrm{g}$ dry wt.) with depth in cores of subsoil collected adjacent to the well. Thus, soil concentrations ranged from 0.5 to 13.8 times the concentrations of alkylpyridines detected in the adjacent well.

Although the distributions were different, alkylpyridines were detected in retort water $(419 \mu \mathrm{g} / \mathrm{ml})$ and in an aqueous extract of shale oil $(35.3 \mu \mathrm{g} / \mathrm{ml})$; however, they were not detected (Table 3 ) in aqueous extracts of raw shale, retorted shale, or Prudhoe Bay Crude $0 i 1(<0.37 \mu \mathrm{g} / \mathrm{ml})$.

If it $c$ an be assumed that the source was shale oil or retort water, the presence of alkylpyridines and the absence of other water-soluble organic compounds (organic acid, phenols) suggest that the alkylpyridines were less subject to sorption on the soil or that they were more persistent than other water-soluble compounds during hydrologic transport. Compounds in 
TABLE 3. Alkylpyridine Concentrations $(\mathrm{mg} / \mathrm{ml})$ in Retort Water and Aqueous Extracts of Shale Oil, Raw Shale, Retorted Shale, and Prudhoe Bay Crude Oil

\begin{tabular}{|c|c|c|c|c|c|}
\hline \multirow[b]{2}{*}{ Compound } & \multirow[b]{2}{*}{ Retort Water } & \multirow[b]{2}{*}{ Shale Oil } & \multirow[b]{2}{*}{ Raw Shale } & \multicolumn{2}{|c|}{ Prudhoe Bay } \\
\hline & & & & Retorted Shale & Crude \\
\hline $\mathrm{C}_{3}$-pyridine & 106.8 & 9.0 & $<0.003$ & $<0.002$ & $<0.01$ \\
\hline C4-pyridine 1 & 33.9 & 3.2 & $<0.002$ & $<0.002$ & $<0.01$ \\
\hline 2 & 84.4 & 4.9 & $<0.002$ & $<0.002$ & $<0.01$ \\
\hline$C_{5}$-pyridine 1 & $<1.6$ & 0.2 & $<0.002$ & $<0.002$ & $<0.01$ \\
\hline 2 & 18.6 & 1.8 & $<0.002$ & $<0.002$ & $<0.01$ \\
\hline 3 & 42.6 & 2.5 & $<0.002$ & $<0.002$ & $<0.01$ \\
\hline 4 & 70.4 & 5.3 & $<0.002$ & $<0.002$ & $<0.01$ \\
\hline 5 & 12.3 & 1.1 & $<0.002$ & $<0.002$ & $<0.01$ \\
\hline 6 & 14.5 & 1.0 & $<0.002$ & $<0.002$ & $<0.01$ \\
\hline 7 & 9.6 & 1.1 & $<0.002$ & $<0.002$ & $<0.02$ \\
\hline C6-pyridine 1 & $<1.6$ & $<0.06$ & $<0.002$ & $<0.002$ & $<0.01$ \\
\hline 2 & 18.3 & 2.4 & $<0.002$ & $<0.002$ & $<0.04$ \\
\hline 3 & 4.4 & 0.5 & $<0.002$ & $<0.002$ & $<0.09$ \\
\hline 4 & $<1.6$ & 1.4 & $<0.002$ & $<0.002$ & $<0.11$ \\
\hline 5 & 3.2 & 0.9 & $<0.002$ & $<0.002$ & $<0.01$ \\
\hline Total Alkylpyridines & 419.0 & 35.3 & $<0.03$ & $<0.03$ & $<0.37$ \\
\hline
\end{tabular}

this class, therefore, require further investigation to define the factors governing their transport to surface and ground waters.

Knowledge of these factors will aid in the evaluation of the use of retort water for dust control and compaction of retorted shale disposal piles. Shale oils and retort waters from other processes also need to be examined for alkylpyridines. The absence of alkylpyridines in aqueous extracts of petroleum indicates that these compounds may be unique and perhaps useful in environmental studies as diagnostic indicators of waters that have been in contact with shale oils. Laboratory and field investigations are currently in progress to determine the hydrologic transport and fate of this class of organic compounds.

Sorption and Degradation of Alkylpyridines. Alkylpyridines were shown to be important water-soluble components of shale oil and liquid effluents produced by oil shale retorting. The presence of these components in surface and ground water has been used as an indicator of impact by oil shale retorting operations. To evaluate the behavior of these compounds in the terrestrial environment after an oil spill has occurred and the oil has migrated from disposal sites, sorption studies were performed with several alkylpyridines on surface-retorted shale and calcareous soil/ subsoil materials from the Colorado oil shale region. Additionally, the rate of microbio- logical degradation of pyridines was determined under aerobic and anaerobic atmospheres to evaluate the persistence of these compounds under conditions indicative of surface (soil, surface water) and subsurface (subsoil, ground water) environs.

Sorption studies were conducted with soil and subsoil materials collected from the DOE Rifle 0il Shale Facility at Anvil Points ( $\mathrm{Ni}-$ hill channery loan) and from the Rio Blanco site on Federal lease Tract $C-a$ (Rentsac silt loam). Initially, emphasis was placed on the sorption of collidine and t-butylpyridine on fresh and field-weathered Paraho retorted shale and on discrete horizons and depth intervals of an alluvial soil/subsoil profile from Anvil Points. The soil/subsoil profile contained significant variations in $\mathrm{pH}(7.0$ to 9.1$)$ and a distribution of soluble $\mathrm{SO}_{4}, \mathrm{CO}_{3}$ and $\mathrm{Cl}$ salts, which reflected seasonal snowmelt infiltration. Sorption was detetermined in aqueous batch systems using high-performance liquid chromatography to measure compound concentrations remaining in solution after equilibration with soil.

Sorption on all substrates followed the Freund ich isotherm, $C_{\text {ads }}=K C_{e q} 1 / n$, where $\mathrm{C}_{\text {ads }}$ is the concentration sorbed in $\mu \mathrm{g} / \mathrm{g}$ and $\mathrm{C}_{\mathrm{eq}}$ is the concentration remaining in solution in $\mu \mathrm{g} / \mathrm{ml} ; \mathrm{K}$ is an equilibrium constant; and $1 / \mathrm{n}$ is an exponent which is commonly less than 1. Isotherms for the sorption of collidine on 
the Paraho retorted shale and the Anvil Points soil materials are shown in Figure 1. Significant quantities of collidine were sorbed in all cases; however, the soil $A$ horizon and the retorted shales were most effective.

The magnitude of adsorption, as measured by the Freundlich distribution coefficients, was most strongly correlated to the concentration of organic carbon. Although this relationship is commonly observed for neutral organic molecules, it was not expected to occur in the Anvil Points soils/subsoils, where 1) the $\mathrm{pH}$ is slightly above the compound pKa $(7.4), 2$ ) organic carbon is low with depth, and 3 ) considerable quantities of clay minerals exist. Apparently, sorption on the organic fraction is more important than ion exchange of the protonated compounds with phyllosilicate minerals. The binding capacity of Paraho retorted shale increased as the shale weathered, thus reflecting a decrease in soluble salts and $\mathrm{pH}$. Possibly more important, however, the increased binding capacity may reflect an increase in organic carbon resulting from progressive revegetation.

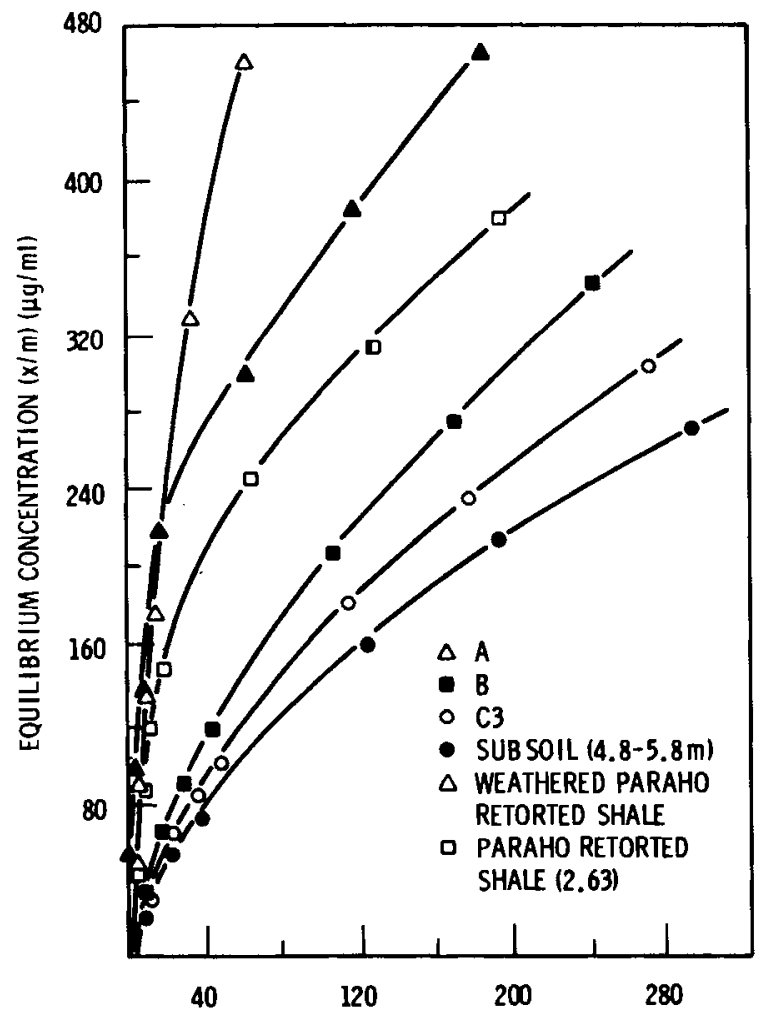

EQUILIBRIUM CONCENTRATION $(\mu \mathrm{g} / \mathrm{ml})$

FICURE 1. Sorption of Collidine on Paraho Retorted Shale and Anvil Points Soil
These studies suggest that certain alkylpyridines, which are present in retort water disposed with retorted shale, may be effectively bound in the disposal site. If released to the environment, these compounds will be strongly sorbed by both $A$ and $B$ horizons and, to a lesser extent, by subsoil materials; this will retard their movement through the soil system. Alkylpyridines may be used as indicators of ground water contamination by retort water (see above) because they resist microbial degradation under reduced oxygen conditions in the substrata (see below), not because they have a high rate of movement through substrata.

Studies of the persistence and biodegradability of pyridines present in alluvial ground waters in the West Sharrard Drainage were investigated in the laboratory. Alluvial ground waters containing alkylpyridines and surface soil collected near the site were used, respectively, as the culture medium and as the microbial inoculum. Degradation was followed with time by monitoring the levels of residual alkylpyridines that were extractable with methylene chloride. Extractable alkylpyridines were identified by GC/MS and quantified by gas chromatography.

In the presence of a soil inoculum and under aerobic conditions, the concentration of extractable pyridine approached zero within 3 days. The rate of decrease was markedly affected by the degree of alkylation of the pyridine ring. This was even apparent with closely related structural isomers. Of two

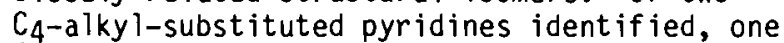
(Component I) was no longer detectable after 10 days of incubation, whereas the second (Component II) was detectable to a level of $18 \%$ at 24 days (Table 4 ).

TABLE 4. Degradation of Pyridines in Alluvial Waters

\% Alkylpyridine Remaining

\begin{tabular}{|c|c|c|c|c|}
\hline \multirow[b]{2}{*}{ Time (days) } & \multicolumn{2}{|c|}{ C4-Pyridine - I } & \multicolumn{2}{|c|}{$\mathrm{C}_{4}$-Pyridine - II } \\
\hline & Control & Inoculated & Control & Inoculated \\
\hline 0 & 100 & 100 & 100 & 100 \\
\hline 3 & 97 & 106 & 99 & 99 \\
\hline 10 & 83 & $<1$ & 85 & 76 \\
\hline 17 & 69 & $<1$ & 72 & 36 \\
\hline 24 & 58 & $<1$ & 60 & 18 \\
\hline 31 & 72 & $<1$ & 68 & 1 \\
\hline
\end{tabular}


With uninoculated controls, both isomers were lost from solution by volatilization at the same rate. Apparently, volatilization is less affected by alkylation of the pyridine ring than is the microbiological process. The addition of $\mathrm{PO}_{4}$ to the culture medium greatly increased both the fungal and bacterial populations, and it decreased the length of time required for complete degradation to 4 days for Component $I$ and to 8 days for Component I1. Under anaerobic conditions, essentially no degradation of the pyridine components was observed for up to 30 days. This suggests that pyridine components have longer persistence in ground waters than in surface waters.

\section{ENVIRONMENTAL STUDIES AT THE RIO BLANCO} SITE, TRACT C-a

The joint laboratory and field study program at the Rio Blanco site, Tract $\mathrm{C}-\mathrm{a}$, Colorado, provides the basis for validating models and developing an understanding of how solid wastes and liquid effluents produced by oil shale processing and mining operations affect the chemical and hydrological characteristics of surface and alluvial ground waters. A generic understanding of these processes will enable identification of real geochemical changes that may occur as the site is developed. This information is necessary to minimize potential impacts arising from ground disposal of oil shale wastes.

Surface and Alluvial Ground Waters. Surface and alluvial ground waters are being collected at Box Elder, Corral, and Upper Yellow Creeks on Tract $\mathrm{C}-\mathrm{a}$ (Figure 1) to define mechanisms regulating the chemical composition of these waters on a seasonal basis. Analyses of water samples immediately following collection included $\mathrm{pH}$, Eh, and conductivity. Subsequent analyses included major and minor cations/ trace metals (acidified and nonacidified samples), major and minor anions, reduced $\mathrm{S}$ species, reduced $\mathrm{N}$ species, and total dissolved $\mathrm{C}$.

The hydrology and chemistry of surface and ground waters are complex. Following the months of maximal snowmelt, surface waters at or near the southwest boundary of the tract originated primarily as seepage from the Uinta Formation. These waters remained relatively constant in composition (conductivity -1100 to 1300 umho), but flowed intermittantly across most of the tract. At the northeast corner of the tract, significant recharge of higher-conductivity water $(1700 \mu$ mho $)$ occurs in both Box Elder and Corral Creeks from diffuse bank seeps near their confluence. In general, stream flow northeast of the tract is seasonally intermittent, and concentrations of many dissolved species (e.g., $\mathrm{Na}, \mathrm{Mg}, \mathrm{Sr}$, $\mathrm{B}, \mathrm{F}, \mathrm{Cl}, \mathrm{SO}_{4}$, and $\mathrm{HCO}_{3}$ ) in Corral and $\mathrm{Yellow}^{\circ}$ Creeks increase in the downstream direction.

With some exceptions, the concentration of most macroions in alluvial ground waters increase downstream in Box Elder, Corral and Yellow Creek drainages. Minor species that follow a similar trend include $B, F, K, M n$ and Fe. Wells in Yellow Creek are significantly more reduced than upstream waters and, in some cases, contain detectable levels of sulfide and ammonia and elevated concentrations of $\mathrm{Mn}$ and $\mathrm{Fe}$. The hydrology of these surface and alluvial ground waters is complicated and influenced by seasonal surface water hydrologic cycles--the effects of continued reinjection of mine waters--and intrusion of deep ground waters. Water quality data are summarized in Table 5 for selected surface waters (Corral Creek at southwest gaging station and Corral Creek at GS-S24), alluvial ground waters (GS-S7 and GS-S28A), and bedrock ground waters $(D-8)$.

Chemical, Microbiological, and Hydrological Characteristics of Mine Dewatering Operations on Tract $\mathrm{C}-\mathrm{a}$. The chemical characteristics of deep ground waters and reinjection waters are being studied by analyzing water samples collected from dewatering and reinjection wells. Deep ground waters (e.g., dewatering wells $D-8, D-6, D-5$, see Figure 2) contain comparable levels of soluble salts to surface waters; however, Sr and, more dramatically, the Sr/Ca ratios, are elevated. Some dewatering wells are reduced with elevated levels of sulfide (25 to $35 \mu \mathrm{g} / \mathrm{ml} \mathrm{HS}^{-}$) and detectable levels of thiosulfate $(2$ to $5 \mu \mathrm{g} / \mathrm{ml})$. They are also charged with dissolved $\mathrm{CO}_{2}$ and $\left(\mathrm{CH}_{4}\right)$. Reinjection waters, which are a mixture of water from several sources, vary in composition (Table 5). Generally, these waters are higher in $\mathrm{pH}$ and more oxidized than deep ground waters, but they contain comparable levels of most macro and minor elements.

Dewatering wells were examined for anaerobic heterotrophic, sulfate-reducing, and methanogenic bacteria to account for processes responsible for the genesis of these chemically-reduced ground waters. Well waters were collected directly in closed tubes, which contained a selective medium and gas phase for each bacterial group. All three bacterial types were found in the dewatering wells. The activity of these bacterial groups may account for at least a portion of the elevated levels of sulfide, $\mathrm{CH}_{4}$ and $\mathrm{CO}_{2}$ measured in some bedrock ground waters (Table 6 ).

The inf requent discharge of reduced ground waters into oxygenated surface water produced 
TABLE 5. Selected Chemical Characteristics of Alluvial, Surface, and Deep Groundwaters at Tract C-a

\begin{tabular}{|c|c|c|c|c|c|}
\hline \multirow[t]{2}{*}{$\begin{array}{l}\text { Chemical } \\
\text { Characteristics } \\
\end{array}$} & GS-S7 & $\begin{array}{l}\text { Corral Creek at } \\
\text { S.W. Gaging Sta. }\end{array}$ & $\begin{array}{c}\text { Corral Creek } \\
\text { at GS-S24 } \\
\end{array}$ & GS-S28A & D-8 \\
\hline & \multicolumn{3}{|c|}{$------(11 / 18 / 80)------$} & \multicolumn{2}{|c|}{$---(3 / 5 / 81)---$} \\
\hline $\mathrm{pH}$ & 8.16 & 8.39 & 8.29 & 8.14 & 7.67 \\
\hline $\mathrm{EC}(\mu \mathrm{mho} / \mathrm{cm})$ & 1305 & 1214 & 2056 & 3194 & 1328 \\
\hline INORG C $(\mu \mathrm{g} / \mathrm{ml} \mathrm{C})$ & 96.0 & 88.5 & 131 & 111 & 130 \\
\hline ORG C $(\mu \mathrm{g} / \mathrm{ml} \mathrm{C})$ & 19.0 & 14.0 & 23.4 & 20.2 & 46.2 \\
\hline $\mathrm{F}^{-}(\mu \mathrm{g} / \mathrm{ml})$ & 0.41 & 0.20 & 0.33 & 0.40 & 0.91 \\
\hline $\mathrm{Cl}^{-}$ & 10.4 & 7.69 & 17.2 & 31.0 & 7.73 \\
\hline $\mathrm{NO}_{3}=$ & 4.23 & 5.85 & 4.08 & 1.87 & ND \\
\hline $\mathrm{SO}_{4}^{2-}$ & 306 & 292 & 630 & 1269 & 307 \\
\hline $\mathrm{S}_{2} \mathrm{O}_{3}{ }^{2-}$ & ND & ND & ND & ND & 1.79 \\
\hline $\mathrm{NH}_{4}+$ & ND & ND & ND & ND & 0.42 \\
\hline B & 0.092 & 0.082 & 0.204 & 0.257 & 0.121 \\
\hline $\mathrm{Ca}$ & 96.5 & 92.7 & 110 & 133 & 51.2 \\
\hline $\mathrm{Cr}$ & 0.019 & 0.029 & 0.035 & 0.040 & 0.022 \\
\hline $\mathrm{Fe}$ & 0.004 & 0.010 & 0.014 & 0.028 & 0.125 \\
\hline$K$ & 1.94 & 0.96 & 2.10 & 2.69 & 0.198 \\
\hline $\mathrm{Li}$ & 0.025 & 0.024 & 0.024 & 0.038 & 0.090 \\
\hline $\mathrm{Mg}$ & 62.5 & 65.3 & 107 & 206 & 89.3 \\
\hline $\mathrm{Mn}$ & 0.002 & ND & 0.012 & 0.403 & 0.020 \\
\hline Mo & 0.021 & 0.027 & 0.051 & 0.045 & ND \\
\hline $\mathrm{Na}$ & 89.7 & 84.6 & 216 & 337 & 184 \\
\hline Si & 10.3 & 10.6 & 8.58 & 9.87 & 16.6 \\
\hline $\mathrm{Sr}$ & 2.08 & 2.07 & 3.12 & 6.64 & 7.49 \\
\hline$S=$ & ND & ND & ND & ND & 25.6 \\
\hline $\mathrm{CO}_{2}(\mathrm{~g})$ & 15.96 & & & 36.3 & 27.9 \\
\hline $\mathrm{CH}_{4}(\mathrm{~g})$ & 0.014 & & & 0.109 & 9.32 \\
\hline
\end{tabular}

ND - Not detected.

visual and chemical changes in water and sediment upon mixing. Immediately after the minewater was discharged, the stream sediments became coated with a thick black precipitate; minutes later, the waters became milky and nearly opaque. The prominent chemical changes identified included $\mathrm{CO}_{2}$ degassing and an associated $\mathrm{pH}$ increase, $\mathrm{H}_{2} \mathrm{~S}$ degassing, and oxidation of $\mathrm{HS}^{-2}$ to $\mathrm{S}_{2} \mathrm{O}_{3}{ }^{2-}, \mathrm{SO}_{4}-2$. Additional chemical effects resulted primarily from dilution of higher conductivity ( 1500 $\mu \mathrm{mho})$ mine waters by lower conductivity $(\sim 1000 \mu \mathrm{mho})$ creek water.

Laboratory studies of the controlled oxidation of deep, reduced ground waters from dewatering well $D-8$ were performed to evaluate chemical processes occurring upon surface discharge of these waters. Any $S^{-}$that is present is oxidized initially and rapidly to colloidal so $\left(\mathrm{T}_{1 / 2}<30 \mathrm{~min}\right)$, giving the water a milky appearance. Continuing oxidation produces $\mathrm{S}_{2} \mathrm{O}_{3}{ }^{-2}\left(\mathrm{~T}_{1 / 2}>30 \mathrm{hr}\right)$ and $\mathrm{SO}_{4}{ }^{-2}$. Carbon dio- $x$ ide degassing occurs along with the oxidation of reduced $S$ species. This reaction increases $\mathrm{pH}$ and causes an apparent supersaturation of the water, which results in precipitation of $\mathrm{CaCO}_{3}$. The black sediment coating observed during field discharge of D-8 water into surface waters results from the precipitation of metal sulfides, principally FeS. Precipitation is encouraged as $\mathrm{CO}_{2}$ degassing upon discharge increases $\mathrm{pH}$ and, temporarily, the activity of $\mathrm{S}^{-2}$.

These studies have shown that complex chemical interrelationships occur between surface, alluvial, and deep ground waters and the mine dewatering cycle. Sampling of these hydrologic units has shown that, in addition to detailed chemical analyses, careful field measurements and sample preservation techniques coupled with analyses of dissolved gases are needed to correctly characterize complex water types from the Piceance Creek Basin. 


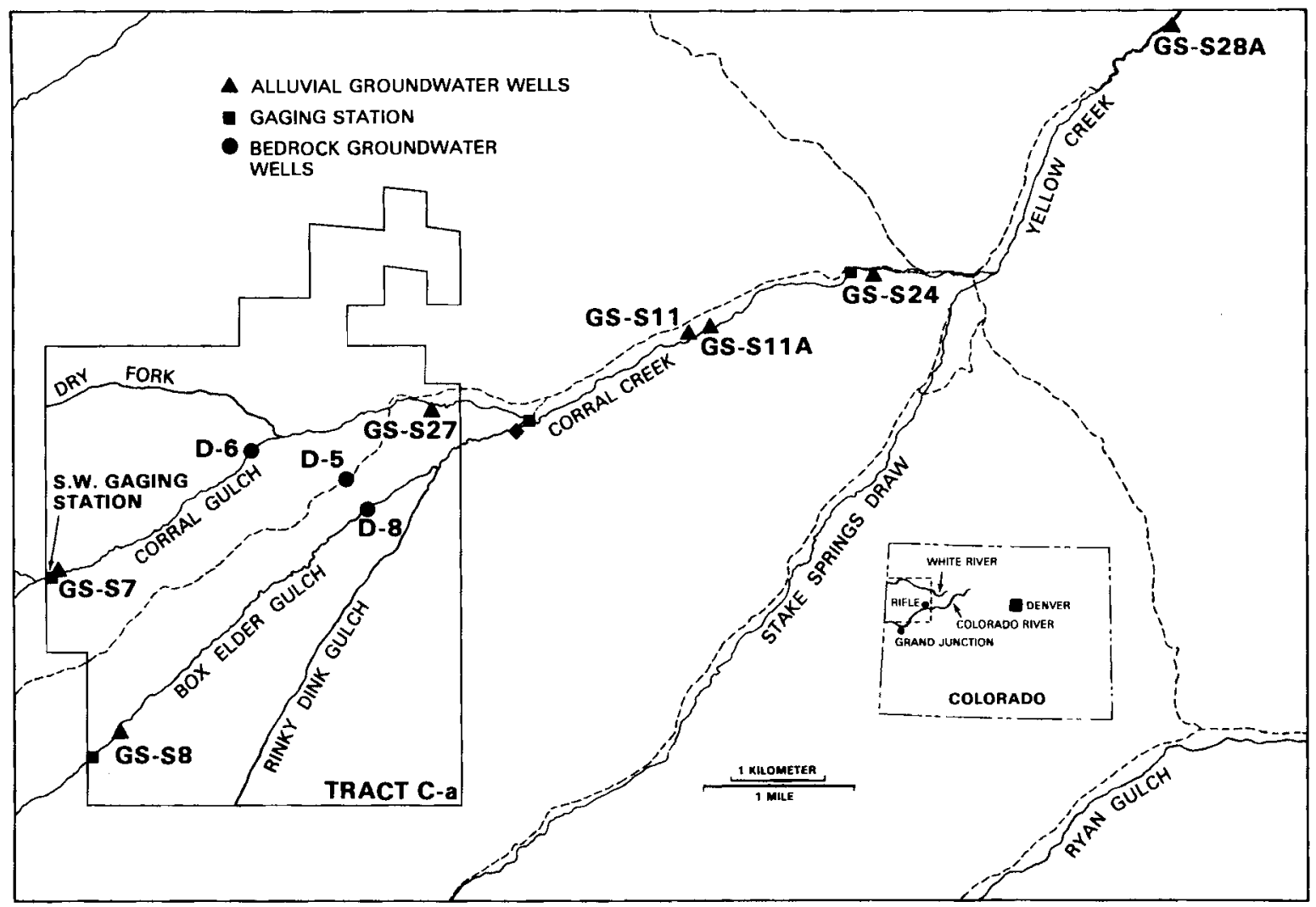

FIGURE 2. Federal Lease Tract C-a

TABLE 6. Dissolved Carbon Dioxide and Methane in Groundwaters from the Piceance Creek Basin

Sample $\mathrm{CO}_{2}, \mu \mathrm{g} / \mathrm{ml} \quad \mathrm{CH}_{4}, \mu \mathrm{g} / \mathrm{ml}$

Alluvial

G5-57 (3/4/81)

GS-S28A Deep (9.8 m, 3/5/81)

AV-3A (Anvil Points, $3 / 7 / 81$ )

$\begin{array}{ll}15.96 & 0.014 \\ 36.32 & 0.109 \\ 59.29 & 0.0013 \\ & \\ 11.03 & 0.0752 \\ 27.89 & 9.32 \\ & \\ 166.8 & 18.9 \\ \end{array}$

ENVIRONMENTAL STUDIES AT THE DOE RIFLE OIL SHALE FACILITY--GEOCHEMICAL MODELING

Since 1979, field studies have been conducted to ident ify the effects of retorted shale disposal on surface and ground water quality proximate to the DOE Rifle 0il Shale Facility.
The studies have defined not only the baseline geochemical regime in a watershed that is characteristic of the southern flanks of the Roan Plateau, but have ident ified spec if ic inorganic and organic compounds that enter waters as a result of unengineered waste disposal. Recently, geochemical modeling techniques using speciation solubility code WATEQ3 have been applied to this data base to identify mineral phases that possibly control water chemistry in surface and ground water above and below the disposal pile. A major objective of the modeling effort was to evaluate possible mineral solubility reactions limiting or modifying the transport of $0 i 1$ chemical species that may arise from oil shale development.

Ground waters above and below the retorted shale pile appeared to be in equilibrium with calcite $\left(\mathrm{CaCO}_{3}\right)$ and dolomite $\left[\mathrm{Ca}, \mathrm{Mg}\left(\mathrm{CO}_{3}\right)_{2}\right]$. Although calcite is a mineral commonly at equilibrium in the ground waters of calcareous terrain, equilibrium with dolomite is less common. Apparently, dissolution of dolomite marlstone fragments in the alluvium maintains unusually high levels of $\mathrm{Mg}$ in the associated 
ground water. Other minerals computed to be near equilibrium included barite $\left(\mathrm{BaSO}_{4}\right)$, cerrusite $\left(\mathrm{PbSO}_{4}\right)$, millerite (NiS), and Otarite $\left(\mathrm{CdCO}_{3}\right)$; these compounds may limit activities of $\mathrm{Ba}, \mathrm{Pb}, \mathrm{Ni}$ and $\mathrm{Cd}$, respectively, in these and other alluvial ground waters of the region. Subsurface waters below the pile contained increased concentrations of $\mathrm{Ca}, \mathrm{SO}_{4}$, $\mathrm{Mn}$, and $\mathrm{F}$, which possibly resulted from the infiltration of retorted shale leachate. All of these chemical species were computed to be in near equilibrium with a solid phase, including gypsum $\left(\mathrm{CaSO}_{4} \cdot 2 \mathrm{H}_{2} \mathrm{O}\right)$, rhodochrosite $\left(\mathrm{MnCO}_{3}\right)$, and flourite.

Mineralogical controls on solubility were also evaluated for surface water above and below the retorted shale pile. Even with seasonal and diurnal fluctuation in discharge, strontonite $\left(\mathrm{SrCO}_{3}\right)$, barite $\left(\mathrm{BaSO}_{4}\right)$, and manganite $[\mathrm{MnO}(\mathrm{OH})]$ appeared to control the activities of $\mathrm{Sr}, \mathrm{Ba}$, and $\mathrm{Mn}$. The complex carbonate, huntite $\left[\mathrm{Mg}_{3} \mathrm{Ca}\left(\mathrm{CO}_{3}\right)_{4}\right]$, limits the activity of $\mathrm{Ca}$ and $\mathrm{Mg}$.
Results of geochemical modeling indicate that a number of dissolved macro and trace inorganic species in surface and ground waters of the Colorado oil shale region may be in equilibrium with, and thus may be controlled by, a series of carbonate, sulfate, and, in isolated cases, sulfide minerals. These controls have the potential for limiting the magnitude of impact on waters. Waters affected by $0 i l$ shale operations (e.g., alluvial ground waters below the retorted shale pile) may reequilibrate (time frame unknown) with these minerals. Depending on the concentrations of the containments, the ground waters may also reequilibrate with other mineral phases.

These studies indicate that a thorough understanding of mineral equilibria is necessary to predict the impact of oil shale development on surface and ground water quality. 
Synfuels 



\section{SYNFUELS}

\section{- Ecological Effects of Coal Conversion (SRC-II)}

\section{- Coal Liquefaction Health and Environmental Effects Document (HEED)}

Research on the potential environmental fate and effects of coal synfuels was undertaken as a generic program, that is, the research was designed to have application to a variety of coal conversion processes (e.g., Solvent Refined Coal (SRC), H-Coal, Donor Solvent and others). However, specific research tasks were initially prioritized for the SRC demonstration plants to be located near Morgantown, West Virginia, and Newman, Kentucky. The SRC process was selected because: 1) detailed design information was available describing how this new technology would operate, 2) SRC was considered the most promising of several liquefaction methods and would reach the demonstration stage first, and 3) suitable coal liquid and solid materials for testing were available.

Early in the development of the research program, DOE established a coordination task force to help define the important environmental issues associated with SRC process development. This task force was comprised of both technology and environmental representatives. Deliberations of the task force had an important bearing on the priorities established for specific research tasks, and also led to publication of the Solvent Refined Coal-II (SRC-II) Detailed Environmental Plan, October 1980.

PNL-3517.

A draft of a similar document describing environmental research that would aid in the development of the SRC-I process was completed in February 1981.

The direction of PNL's synfuels research, established in deliberations with the task force mentioned above, was based on the following considerations:

- Principal coal conversion materials likely to enter the environment would be coal liquids from accidental spills during loading and transportation, and spent residues (solids) from gasifier units.

- In the East, waterways would be principal corridors for movement of bulk coal liquids.

- Leachates from stored spent residues may contaminate ground water; their organic content might be low, but mineral fraction enrichment would be of chief concern.

- Sulfur would be internally recycled and removed as a solid by-product in any new facility. Sulfur gases likely to be released would be in compliance with current federal standards. 
- "Fugitive" emissions (i.e., valve leaks of process water and coal liquids) would be collected and incinerated.

- Because of major operational differences and major differences in control technology, existing pilot plant facilities did not provide a realistic basis for the design of trend-monitoring programs appropriate to liquefaction plants.

This annual report summarizes the most recent findings as they apply to the ecological fate and effects of coal synfuels in the environment. Ecological research tasks are organized under three principal tasks: 1) chemical characterization and fate, 2) ecological fate and effects, and 3) environmental pathways modeling. Task 2 is further divided into five subtasks: bioavailability and food chain transfer in aquatic systems, bioavailability and food chain transfer in terrestrial systems, chronic screening in aquatic systems, lysimeter screening in terrestrial systems, and ecosystem-level response studies. The rationale, methods, and results for each task and subtask are described herein. Although experimental protocols were initially developed for study of the SRC-II process, they are being applied to other coal conversion options as DOE requires, and as other representative source materials become available.

A major status report covering three years experience in th is project was published in October 1981. The report includes a detailed evaluation of ecological issues and implications, based on new data derived in other segments of the comprehensive DOE program, and should be consulted for detailed information.

Ecological Fate and Effects of Solvent Refined Coal (SRC) Materials: A Status Report. J. A. Strand and B. E. Vaughan, Editors. PNL-3819. October 1981.

Late in FY 1981, effort was initiated to commence an iterative study series on the assessment of health and environmental effects (HEED) resulting from coal liquefaction. Three years experience in the comprehensive DOE program has now made feasible the commencement of assessment effort, as envisioned in the Detailed Environment Plan mentioned above.

Detailed research findings on acute screening are reported in our Annual Report for 1981 on Interagency/Contract Research, Ecological Sciences Department. 


\section{- Ecological Effects of Coal Conversion}

Principal Investigator: J. A. Strand

Associate Investigators: R. M. Bean, D. A. Cataldo, D. D. Dauble, W. E. Fallon, L. J. Felice, J. T. Hardy, P. J. Mellinger, T. L. Page, J. E. Rogers, J. R. Skalski, and M. L. Warner

The objectives of this research program are to 1) determine the fate of coal conversion product, process, and waste materials potentially released to the environment; 2) determine effects of these materials and their transformation products on aquatic and terrestrial systems; and 3) determine food chain transfer of potentially deleterious materials to man. The research necessarily focuses on water-soluble, persistent materials with greatest potential for mobility and incorporation into water, sediments, soils, and man's food supplies.

\section{CHEMICAL CHARACTERIZATION AND FATE}

Non-occupational health effects associated with coal conversion processes will be determined by environmental factors governing the form, transport, and persistence of coal conversion products and wastes--factors which also mediate exposure to man. Accordingly, the research described below is an attempt to determine the fate of disposed solid wastes and spilled product, and its necessarily focuses on water soluble and persistent materials that may enter water, soils, and sediment systems.

Soil Sorption of Coal Liquefaction Materials. To determine the fate of coal liquefaction materials in aquatic and terrestrial environments, it is necessary to characterize the physicochemical interactions of key coal liquefaction components within soils and sediments. In an effort to define these interactions, a series of soil sorption studies was completed with aniline, phenol, and selected alkyl-substituted anilines and phenols. These compound types were shown to account for the majority of water-soluble organics in an SRCII blended distillate $(2.9: 1.0)$, and in a variety of coal-derived liquids. This work was initiated in FY 1980, and preliminary findings were presented in last year's Annual Report (PNL-3700, PT2). Much of this work has been completed and is presented in this report.

Soils used in this study were collected from Newman, Kentucky, and Ft. Martin, West Virginia. Detailed chemical and physical characterizations of these soils have been completed and will allow the correlation of sorption behavior with various soil features ( $\mathrm{pH}$, organic carbon, amorphous and crystalline iron oxides, and clay mineral content. Measurement of adsorption isotherms was performed on the genetic horizons ( $A 1, B 1, B 22$ ) of the Elk silt loam (Kentucky, Alfisol) and in the Westmore- land silt loams (West Virginia, Alfisol). Batch studies were used, and sorption was followed by direct, high performance liquid chromatographic analysis of compounds remaining in the aqueous solution after equilibration with soils.

Sorption measurements with the three horizons of the Elk and Westmoreland soils were completed for aniline, 4-methylaniline, 2,4-dimethylaniline and 2,4,6-trimelylaniline. In all cases, the sorption behavior could be described by the Freundlich equation:

$$
S=K C^{1 / n}
$$

where

$$
\begin{aligned}
& S \text { = concentration of solute } \\
& C=\text { solution concentration of } \\
& K=\text { an equilibrium constant } \\
& 1 / n=a \text { constant } \text {. }
\end{aligned}
$$

The Freundlich constants describing the sorption of the anilines are presented in Table 1. All the isotherms obtained were non-linear as shown by $1 / n$ values of greater than or less than 1. Generally, the magnitude of sorption increased with alkyl substitution, but the methylaniline and dimethylaniline were most strongly bound in both soils. One striking feature of the sorption behavior of the anilines was the large magnitude of sorption seen in the 822 horizons. This is illustrated for aniline in Figure 1. Numerous published studies have suggested that the sorption of neutral organic compounds in soil is largely controlled by the distribution of organic carbon through the soil profile. However, the degree 
TABLE 1. Freundlich Constants (K, $1 / n)$ for Anilines

\begin{tabular}{|c|c|c|c|c|c|c|c|c|c|}
\hline \multirow[b]{2}{*}{ Soil Horizon } & \multirow[b]{2}{*}{$\%$ Org. C } & \multicolumn{2}{|c|}{ Aniline } & \multicolumn{2}{|c|}{ 4-Methylaniline } & \multicolumn{2}{|c|}{ 2,4-dimethylaniline } & \multicolumn{2}{|c|}{$\begin{array}{c}2,4,6-\text { Trimethyl- } \\
\text { aniline }\end{array}$} \\
\hline & & $K$ & $1 / n$ & K & $1 / n$ & $\mathbf{K}$ & $1 / n$ & $\mathrm{~K}$ & $1 / n$ \\
\hline \multicolumn{10}{|l|}{ Westmoreland } \\
\hline A1 & 2.0 & 2.6 & 0.71 & 6.6 & 0.46 & 7.3 & 0.34 & 7.0 & 0.30 \\
\hline B1 & 0.98 & 1.9 & 0.89 & 4.2 & 0.51 & 4.8 & 0.47 & 4.0 & 0.35 \\
\hline B22 & 0.15 & 2.9 & 1.2 & 4.3 & 0.77 & 4.1 & 0.81 & 2.7 & 0.66 \\
\hline \multicolumn{10}{|l|}{ Elk } \\
\hline A1 & 1.7 & 3.9 & 0.79 & 5.6 & 0.38 & 6.9 & 0.42 & 5.4 & 0.31 \\
\hline B1 & 0.45 & 6.0 & 1.2 & 7.1 & 0.93 & 6.7 & 0.82 & 4.5 & 0.54 \\
\hline B22 & 0.27 & 8.0 & 1.4 & 10.0 & 1.1 & 9.7 & 0.93 & 6.5 & 0.74 \\
\hline
\end{tabular}

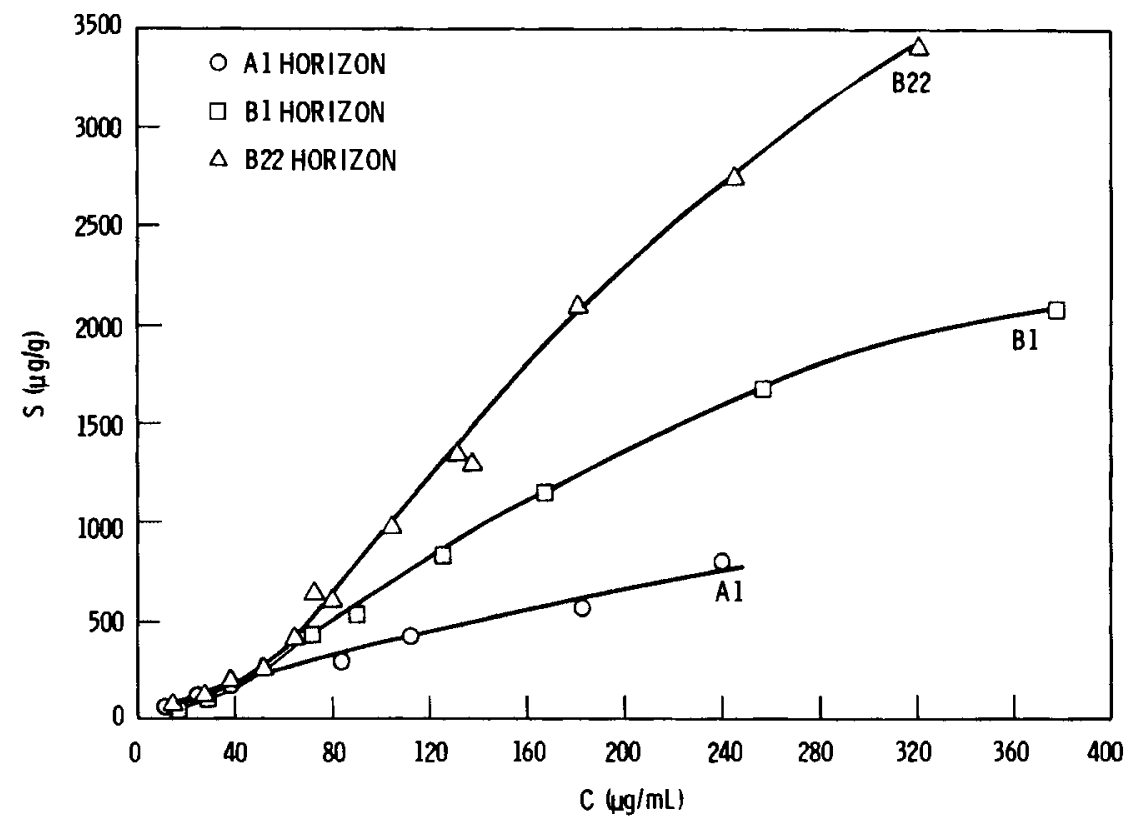

FIGURE 1. Aniline Sorption Isotherms on Elk Silt Loam

of sorption observed in the B22 horizons of these alfisols suggests an inorganic or mineralogic control in these horizons. In the Elk soil, more aniline is sorbed in the $B 22$ than in the A1 horizon. This trend is reversed in the Westmoreland soil and reflects the increased organic carbon content of the Westmoreland $A 1$ horizon relative to the Elk. The mechanism responsible for the strong adsorption in the B22 horizon is currently under study.

The adsorption of phenol and 4-methylphenol was also examined and markedly contrasts the behavior of the anilines (Figure 2). The sorption of phenol and 4-methylphenol $c$ an also be described by the Freundlich equation. The isotherms are linear $(1 / n=1)$ or nearly linear. The magnitude of sorption of the phenols was significantly less than that of anilines and appeared to be controlled solely by interaction with the soil organic fraction. Alkyl substitution of phenol increased sorption in the Al horizon. Unlike the anilines, sorption of the phenols in the B22 horizons was minimal; sorption in the Elk B1 and B22 was too low to measure. 


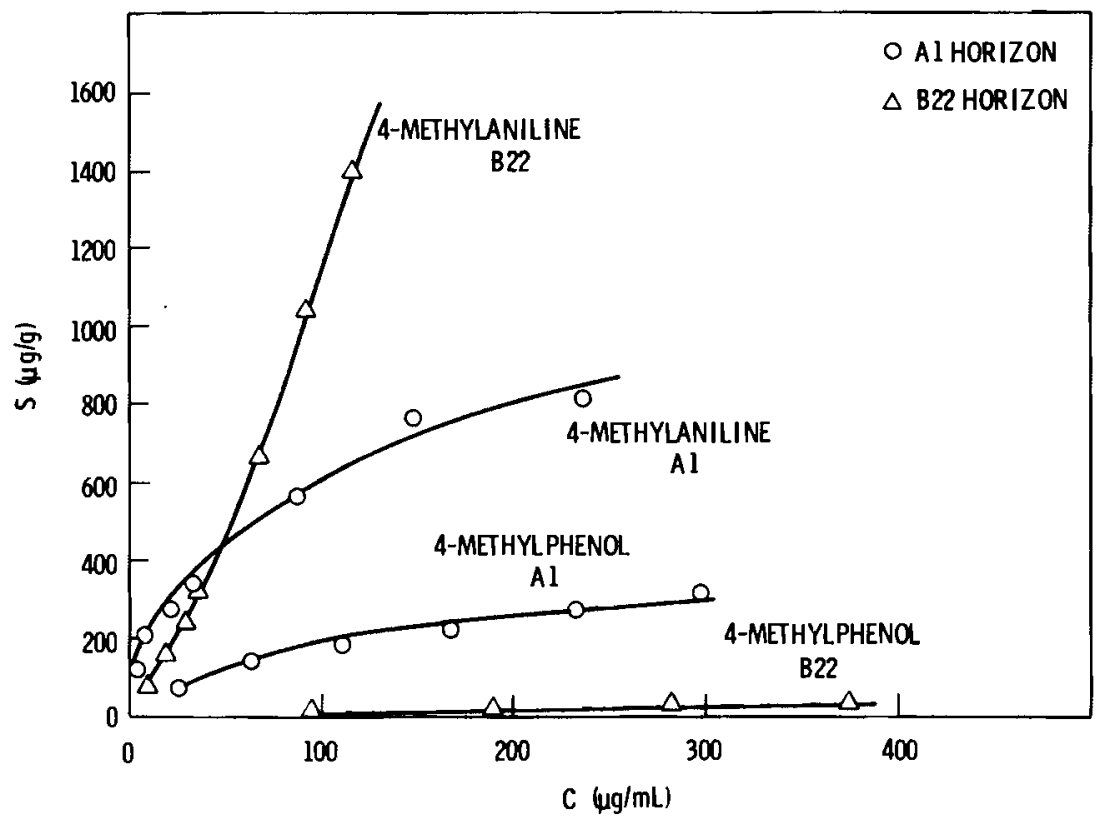

FIGURE 2. Sorption Isotherms of 4-Methylaniline and 4-Methylphenol on Elk Silt Loam

Based on sorption studies alone, it is expected that in soil, alkyl phenols would be more mobile than alkyl anilines. Movement of certain phenols in the $B$ horizons would be unimpeded. On the otherhand, because anilines interact strongly with all horizons, their movement would be significantly retarded by each genetic unit, or horizon, of the soil profile. In the case of terrestrial product spillage under temperate climatic conditions, water-soluble phenols would comprise an immediate threat to ground water supplies. The actual magnitude of impact would be dependent upon the quantity of materials spilled and the rate of water movement through soil. However, soil interactions alone cannot be used to predict the impact of chemical spills to the environment. The microbiological metabolism can profoundly affect the environmental fate of organics and must also be considered. Evaluation of the microbial persistence of anilines and phenols is currently under investigation in our laboratory. Preliminary results from these studies are presented in the following section.

Microbial Degradation of Coal Liquefaction Materials in Soils. Initial studies were focused on the rate and mechanism of the microbiological degradation of 3-methylaniline as a representative ring-substituted alkylaniline. The degradation rate was estimated by monitoring the formation of $14 \mathrm{CO}_{2}$ in soil suspensions ( $1: 5$ soil-to liquid ratio) spiked with 200 ppm 3-methylaniline, which contained trace levels of uniformly ring-labeled $14 \mathrm{C}-3-$ methylaniline. Incubation of spiked soil suspensions for 90 days indicated that less than $3 \%$ of the 3-methylaniline was converted to $\mathrm{CO}_{2}$. Essentially no conversion to $\mathrm{CO}_{2}$ was observed in the first 18 days of incubation. Apparently the mineralization of 3-methylaniline, and possibly other aniline derivatives, is very slow. This slow rate of mineralization may be partly due to resistance of the 3-methylaniline structure to microbial attack. It may also be due to the formation of intermediate degradation products that are resistant to further metabolism, or to the sorption of aniline to the mineral matrix, which reduces its availability to microorganisms.

To test some of these possibilities, a second approach to the investigation of the microbial degradation of 3-methylaniline was developed. This approach involves measuring ${ }^{14} \mathrm{C}$, 3-methylaniline, and possible degredation products present in aqueous phases and extracts of the soil matrix. Pyrolysis of the soil residue and analysis of the various extracts will give a material balance and be useful for evaluating the fate of the 3-methylaniline. Threemethylaniline and possible degradation products are determined using both high pressure liquid chromatography and thin layer chromatography. Although these studies are only partially complete, preliminary results suggest that after 16 days of incubation, $14 \mathrm{C}$-activity 
associated with the aqueous phase was reduced $66 \%$ with respect to that observed in the 4-hour incubation. Sterile controls were reduced only $15 \%$ over this period. No ${ }^{14} \mathrm{CO}_{2}$ was formed during the 16-day incubation, which suggests that 3 -methylaniline is being modified by microorganisms but is not being metabolized to $\mathrm{CO}_{2}$.

Results of this study should allow us to interpret the microbial degradation of 3-methylaniline and its relationship to the persistence of 3-methylaniline in soils. Comparable studies are planned to evaluate the persistence of substituted phenols in soils of the eastern coal regions.

\section{ECOLOGICAL FATE AND EFFECTS}

Based on an analysis of petroleum industry statistics, there exists a high probability for spillage of coal liquids into surface waters and terrestrial habitats when the synfuels industry is commercialized. There is clearly a need to determine the potential for food chain transfer of coal synfuel residues to man, and to determine the potential harmful effects on aquatic and terrestrial ecosystems, either directly or via their transformation products.

Bioavailability and Food Chain Transfer in Aquatic Systems. In these studies, the uptake and retention of aniline and phenol were studied in the green alga, Scenedesmus quadricanda. Coal liquids contain relatively high concentrations of phenols, and aniline is a nitrogen containing aromatic hydrocarbon which has the potential of entering aquatic food chains. Scenedesmus is representative of the base of most aquatic food chains.
Preliminary results indicated a rapid uptake of both ${ }^{14} \mathrm{C}-\mathrm{labeled}$ aniline and phenol over the first 1 to 2 hours. This was followed in both cases by a slower rate of uptake over the next 22 hours. The loss of both ${ }^{14} \mathrm{C}$-labeled aniline and phenol followed essentially a biphasic course with an initial rapid elimination in the first 1 to 2 hours followed by a slower elimination rate during the next 22 hours. As shown in Table 2, the estimated concentration factor for aniline was between 2.6 and 379 ; for phenol the value was between 4.5 and 33 .

These studies will be expanded in Fy 1982 to include verification of recovery techniques for radio-labeled compounds and chemical characterization of possible degradation products.

Bioavailability and Food Chain Transfer in Terrestrial Systems. In these studies, the capacity of terrestrial plants to absorb representative coal liquefaction product components (phenol and aniline) was examined, along with their metabolic fate as either parent chemical compounds or decomposition products. The studies are essential to the development of a detailed understanding of the behavior of coal liquefaction components in plant systems.

Hydroponically grown soybean plants were used to study the adsorption and chemical fate of phenol and aniline, which are two representative components of coal synfuels Preliminary studies showed phenol and aniline induced severe phenotypic and toxicologic responses at concentrations in excess of 50 and $10 \mathrm{ppm}$, respectively. In subsequent studies conducted at the above, marginally toxic, levels, ${ }^{14} \mathrm{C}$ labeled phenol and aniline were used to obtain data on adsorption rate, plant distribution and chemical fate.

TABLE 2. Uptake, Elimination, and Bioconcentration of ${ }^{14} \mathrm{C}$-labeled Aniline and Phenol by Scenedesmus

\begin{tabular}{|c|c|c|c|}
\hline Compound & $\begin{array}{c}\text { Mean } \\
\text { Exposure } \\
\text { Level } \\
(\mathrm{nM} / \mathrm{ml}) \\
\end{array}$ & Uptake Equation(a) & Depuration Equation(a) \\
\hline${ }^{14} \mathrm{C}$-aniline & 5.07 & $\begin{aligned} 1 / H & =2.15\left(10^{-3}\right) / t \\
& +0.52\left(10^{-3}\right) \\
r^{2} & =0.97\end{aligned}$ & $\begin{aligned} 1 / H & =1.37\left(10^{-4}\right) / t \\
& +1.34\left(10^{-3}\right) \\
r^{2} & =0.99\end{aligned}$ \\
\hline${ }^{14} \mathrm{C}$-phenol & 3.84 & $\begin{aligned} 1 / H & =0.043 / t+0.008 \\
r^{2} & =0.984\end{aligned}$ & $\begin{aligned} 1 / H & =-0.012 / t+0.036 \\
r^{2} & =1.000\end{aligned}$ \\
\hline
\end{tabular}

(a) $\mathrm{H}=$ compound ( $\mathrm{nM} / \mathrm{g}$ dry wt.); $\mathrm{t}=$ time in hours.
Bioconcentration

\begin{tabular}{|c|c|c|c|}
\hline \multicolumn{2}{|c|}{ Factor } & \multirow[b]{2}{*}{$\begin{array}{c}\text { Depuration } \\
\text { Half-Life } \\
\text { (hr) }\end{array}$} & \multirow[b]{2}{*}{$\begin{array}{l}H \text { max } \\
\text { (nM/g } \\
\text { dry wt.) } \\
\end{array}$} \\
\hline $\begin{array}{l}\text { Projected } \\
\text { Steady } \\
\text { State }\end{array}$ & Kinetic & & \\
\hline 379 & 2.6 & 0.46 & 1923 \\
\hline
\end{tabular}

33

4.5

0.60

125 
Phenol was adsorbed at $2130 \mu \mathrm{g} g$ fresh weight root $^{-1}$ day- $^{-1}$. Approximately $40 \%$ of $14 \mathrm{C}$ activity associated with phenol was transported from root to shoot. Physical fractionation of leaves and roots showed that $11 \%, 1 \%$ and $88 \%$ of the ${ }^{14} \mathrm{C}$ activity was associated with insoluble residue, organelles, and the soluble fraction of leaves, respectively. The distributions for root tissues were $38 \%, 8 \%$ and $54 \%$, respectively. Greater than $80 \%$ of the ${ }^{14} \mathrm{C}-\mathrm{ac}-$ tivity associated with solubles of roots and leaves was apparently metabolized to higher molecular weight compounds. This finding was supported by detailed chemical analyses of phenol contained in each molecular weight fraction. After 24 hours of metabolism, $18 \%$ of the ${ }^{14} \mathrm{C}$ was associated with phenol, while after 72 hours this fraction was only $\sim 1 \%$.

Plant adsorption rate for ${ }^{14} \mathrm{C}$-aniline was substantially lower than for phenol $(\sim 10 \mu \mathrm{g} \mathrm{g}$ fresh weight root-1 day-1). Transfer from root to shoot was less than $10 \%$ after 72 hours. Unlike phenol, aniline exhibited a strong tendency to sorb to all wall materials ( $>70 \%$ of the ${ }^{14} \mathrm{C}$-labeled aniline was sorbed); this resulted in an uncertain adsorption ratio. Physical fractionation of leaves and roots showed $31 \%, 2 \%$ and $67 \%$ of the ${ }^{14} \mathrm{C}$ activity was associated with insoluble residue, organelles, and the soluble fraction of leaves, respectively. The distribution for root tissue was $73 \%, 3 \%$ and $24 \%$, respectively. Less than $40 \%$ of $14 \mathrm{C}$ activity associated with the solubles of roots and leaves appeared to be metabolized to higher molecular weight components. Unlike phenol, $\sim 25 \%$ of the ${ }^{14} \mathrm{C}$ assoc iated with the solubles persisted as aniline after 24 hours of metabolism. This increased to $\sim 40 \%$ after 72 hours of uptake, thus indicating a significant persistence of aniline.

In general, these studies demonstrated a complex interaction for organic pollutants entering the food chain, and emphasize the need to evaluate specific components of coal synfuels for both bioavailability and chemical fate. Obvious differences in the phytotoxicity, adsorption and chemical fate of phenol and aniline suggest the need for a tiered screening procedure to identify spec if ic pollutants of concern and undertake procedures to ameliorate their detrimental impact.

Chronic Effects Screening in Aquatic Systems. These studies were designed to research more fully the longer-term effects of spilled coal liquids in surface waters. All studies were conducted using a 2.9-to-1.0 blend of middleto-heavy distillates derived from the SolventRefined Coal (SRC II) process and obtained from the pilot plant in Fort Lewis, Washington.
Both fathead minnow, Pimephales promelas, and rainbow trout, Salmo gairdneri, were used as test species because they represent different trophic levels and are found in a wide variety of freshwater habitats.

In studies completed in FY 1980, we learned that concentrations of both phenolic compounds and hydrocarbons were rapidly reduced in static test solutions. Accordingly in FY-1981, to achieve more stable exposure conditions over longer periods, we turned to the use of continuous-flow bioassays. A previously developed mix-and-separation device was used to generate the water-soluble fractions (WSF) tested, and the chemical constituents present in the test aquaria were characterized during the cont inuous-flow bioassays.

Detailed chemical characterizations were done for 1) the stock WSF as diluted for testing, and 2) the components present in representative test aquaria. Two different test series were performed. The results from one test are presented in Table 3. Phenols were the major constituents in both the stock WSF and test aquaria. Aromatic and saturate hydrocarbons were present at $\leq 0.1 \mathrm{ppm}$ for the highest concentration tested. With the exception of phenol, percent composition of the phenolic compounds and hydrocarbons did not substantially differ as the stock WSF was diluted to sublethal test concentrations. Phenol contributed $14.7 \%$ of the total phenols in the stock WSF, but on $1 y 2.5 \%$ and $0.6 \%$ in the high and low test concentrations, respectively. These data show that some WSF compounds (phenol) may not be of long-term biological significance. Mechanisms responsible for the loss of phenol may include volatilization, photodegration, chemical degradation or possibly selective bacterial degradation. The importance of bacterial degradation in environmental modification of coal liquid WSF components will be examined in greater detail in FY 1982.

Separate long-term exposure tests were conducted with rainbow trout (Salmo gairdneri) and eggs (early-eyed stage) of fathead minnow (Pimephales promelas). Both species were exposed to the diluted stock SRC-II WSF for 30 days post-hatch. Routine chemical analys is was performed using a rapid dye photometric assay. Premature hatching and death of rainbow trout occurred at the high test concentrations ( $>1.30 \mathrm{ppm}$ dye-phenols). Abnormal development was observed at concentrations $>0.32 \mathrm{ppm}$ dye-phenols. At the lowest concentration tested ( $0.13 \mathrm{ppm}$ dyephenols), $<2 \%$ of the fish survived the 42-day exposure period. Mortality of rainbow trout fry that survived 
TABLE 3. Chemical Constituents in Stock Water-Soluble Fractions (WSF) and Test Aquaria During the Embryo-Larvae FlowThrough Exposure Test for Fathead Minnow

\begin{tabular}{|c|c|c|c|}
\hline Chemical Component & $\begin{array}{c}\text { Stock WSF } \\
\text { (ppm) }\end{array}$ & $\begin{array}{c}\text { High Test } \\
\text { Concentration } \\
\text { (ppm) } \\
\end{array}$ & $\begin{array}{c}\text { Low Test } \\
\text { Concentration } \\
\text { (ppm) }\end{array}$ \\
\hline \multicolumn{4}{|l|}{ Phenols } \\
\hline Phenol & 158.50 & 0.01 & 0.0002 \\
\hline Cresols & 339.80 & 0.09 & 0.0072 \\
\hline $\mathrm{C}_{2}$ phenols & 260.40 & 0.13 & 0.0129 \\
\hline $\mathrm{C}_{3}$ phenols & 142.70 & 0.08 & 0.0063 \\
\hline $\mathrm{C}_{4}$ phenols & 32.90 & 0.01 & 0.0007 \\
\hline Indanols & 78.40 & 0.05 & 0.0047 \\
\hline$\geq \mathrm{C}_{5}$ phenols & 63.30 & 0.03 & 0.0019 \\
\hline Total phenols & 1076.00 & 0.40 & 0.0339 \\
\hline \multicolumn{4}{|l|}{ Aromatic Hydrocarbons } \\
\hline$C_{2}$ Benzenes & 0.68 & 0.0025 & 0.0018 \\
\hline$C_{3}$ Benzenes & 0.78 & 0.0013 & 0.0001 \\
\hline Indan & 0.86 & 0.0016 & 0.0001 \\
\hline$C_{4}$ Benzenes & 2.14 & 0.0037 & 0.0002 \\
\hline Tetralin & 1.96 & 0.0037 & 0.0003 \\
\hline Naphthalene & 3.53 & 0.0083 & 0.0006 \\
\hline$C_{5 / 6}$ Benzenes, $C_{1}$ Tetralin & 9.40 & 0.0202 & 0.0009 \\
\hline$C_{1}$ Naphthalene & 4.35 & 0.0102 & 0.0007 \\
\hline$C_{2}$ Naphthalene & 2.72 & 0.0055 & 0.0007 \\
\hline$C_{3}$ Naphthalenes, $C_{1 / 2}$ Fluorenes & 7.80 & 0.0212 & 0.0038 \\
\hline Phenanthrene & 1.58 & 0.0035 & 0.0002 \\
\hline$C_{1}$ Phenanthrene & 0.76 & 0.0018 & $<0.0001$ \\
\hline Fluorene & 0.33 & 0.0007 & 0.0001 \\
\hline Pyrene & 0.62 & 0.0012 & 0.0001 \\
\hline Total aromatics & 37.51 & 0.0854 & 0.0096 \\
\hline \multicolumn{4}{|l|}{ Saturate Hydrocarbons } \\
\hline Total saturates & 0.80 & - & - \\
\hline
\end{tabular}

the yolk sac stage was attributed to clogging of the gills with detritus and the subsequent growth of microorganisms (bacteria, fungi), which were present in the test aquaria water.

Fathead minnow appeared less sensitive than rainbow trout to SRC-II WSF components. Because of variability among replicates, control survival was not significantly different from that at the highest concentration tested (1.21 ppm dye-phenols). However, growth of larval fathead minnow (mean size and weight) was suppressed at $0.24 \mathrm{ppm}$ dye-phenols

(Figure 3).

Behavioral studies associated with avoidancel attraction mechanisms were completed with fathead minnow. Strong avoidance of the SRC-II WSF was observed at 3.5 to $7.0 \mathrm{ppm}$ dye-phenols, some avoidance was observed at 1.7 to $3.5 \mathrm{ppm}$ dye-phenols. No avoidance was observed at concentrations near 0.8 ppm dye-phenols (Figure 3 ).
Preliminary tests with rainbow trout indicated little avoidance of SRC-II WSFs at concentrations near $3.0 \mathrm{ppm}$ dye-phenols. Juvenile rainbow trout did not avoid lethal concentrations, as demonstrated by mortalities observed during some of the test series.

Additional tests conducted with mature fathead minnow pairs over a 21-day exposure period showed that spawning was inhibited at 1.27 dye ppm phenols (Figure 3 ). Total egg production at the lowest concentration tested $(0.07 \mathrm{ppm}$ dye-phenols) was only $70 \%$ of the controls. Production was significantly reduced ( $\alpha=0.10$ ) at SRC-II WSFs near $1.2 \mathrm{ppm}$ dye-phenols.

Further studies showed that males actively clean spawning substrate; hence, the physical effect of microbial growth may not be as important a limiting factor on successful reproduction as chemical components that suppress necessary behavioral mechanisms. We will conduct more research in FY 1982 to determine the 


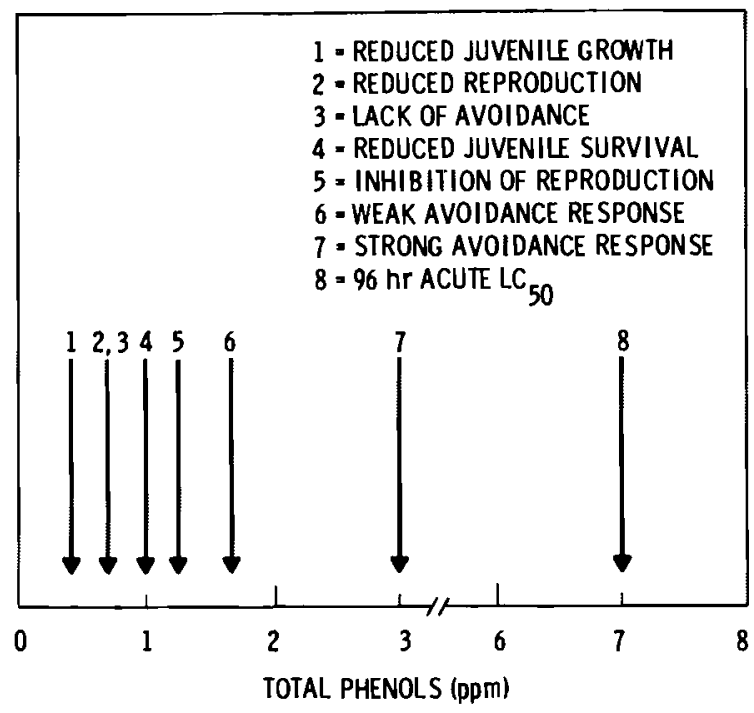

FIGURE 3. Responses of Fathead Minnow to WSFs of SRC-II Liquid under Continuous-Flow Regimens

effects of coal liquid WSFs and their components on the reproductive behavior of fathead minnow.

Acute Effects Screening of Solvent Refined Coal Materials. Acute toxicity tests of SRCII water-soluble fractions (WSF) on three reference organisms were completed. Acute toxicity tests are designed to provide a means of biologically screening coal liquids and/or chemical fractions. Acute toxicity data is also required for the generic environmental impact statement and various federal and state permits. This acute-toxicity data base included tests under standard and variable water quality conditions.

Mean LC50 values in ppm total carbon (TC) under standard conditions (Columbia River water at $20^{\circ} \mathrm{C}, \mathrm{pH} 7.2$ to 8.2 , hardness 65 to $80 \mathrm{ppm}$ $\mathrm{CaCO}_{3}$ ) were: 3.3 for Daphnia magna, 11.1 for Pimephales prome las Raf and 13.7 for Chironomus tentans Fab larvae.

Water quality appeared inconsequential in affecting overall chemical composition of WSFs. observed differences in toxicity associated with temperature, $\mathrm{pH}$, and hardness were attributed to variations in physiological responses of test organisms.

A new flow-through dilutor system was developed for testing both WSFs and oil-water dispersions (OWD) simultaneously. The system provides variable mixing energy and allows tests of less toxic petroleum products. In two such tests, the OWDs were found to be more toxic than WSFs from SRC-II, based on equal TC concentrations. Enhancement in certain aromatic hydrocarbon classes was observed in the OWDs. Detailed research findings for these acute effects studies are reported in our Annual Report for 1981 on Interagency/Contract Research, Ecological Sciences Department.

Lysimeter Screening in Terrestrial Systems. Before synthet ic fuels from coal become common products in commerce, estimates need to be developed of the type, severity, and duration of effects on either managed or natural terrestrial ecosystems, as might result from accidental spills. This study sought to identify the effects potentially associated with the SRC-I I 2.9:1.0 middle-to-heavy distillate blend. This year's study objectives were: 1) to ident ify acute effects on plant productivity and to identify the SRC-II material concentration range within which these effects occur; 2) to compare effects observed with those associated with No. 2 fuel oil, a commonly available commercial product; 3 ) to investigate the potential reduction in damages associated with three possible spill clean-up alternatives; 4) to grow plant material exposed to SRC-II in soil for later analysis of bioaccumulated SRC residues; and 5) to establish a standard protocol for testing and comparing a variety of future synthet ic fuel materials.

Vegetative productivity was studied because of its universal importance in all terrestrial and agricultural ecosystems. Cause-effect relationships can probably be documented better for vegetative productivity than for most other ecosystem components or functional indicators. 
Field lysimeters ( $1 \mathrm{~m}$ by $15 \mathrm{~cm}$ diameter) containing Richland, Washington, silt-loam soil were spiked with three different concentrations of either the SRC-II material or No. 2 fuel oil. The SRC-II material or fuel oil was introduced to the lysimeter soil in one of three following modes to simulate possible spill clean-up actions: 1) sprinkled on the soil surface, 2) placed as a layer $1 \mathrm{dm}$ below the soil surface, or 3) thoroughly mixed with the top $1 \mathrm{dm}$ of soil. The lysimeters were planted with barley (Hordeum vulgare), fertilized, and grown in the field. Soil moisture was maintained at $20 \%$ by weight. Field tests were conducted in Richland, Washington, during the April through July growing season.

Data obtained have not yet been thoroughly analyzed, but preliminary findings suggest that at the three concentrations tested $\left(0.07 \mathrm{~L} / \mathrm{m}^{2}, 0.74 \mathrm{~L} / \mathrm{m}^{2}\right.$, and $\left.7.42 \mathrm{~L} / \mathrm{m}^{2}\right)$ both the SRC-II material and No. 2 fuel oil produced generally similar effects. Where differences occurred, the SRC-II material was the more toxic. Observed effects included reduced seed germination, reduced yield of both seeds and shoots, and delayed plant maturation. Of the three spill cleanup options tested, only alternative 1 (leaving the spilled material on the soil surface) appeared to reduce observed effects.

Complete analysis will involve testing the statistical validity of these preliminary findings and quantifying the effects observed.

Ecosystem-Level Response Studies. Potential effects that a spill of coal liquids might have on an ecosystem cannot be adequately assessed or predicted solely on the basis of acute or chronic, single-species laboratory toxicity tests. Effects must ultimately be determined and verified in the field. Field verification also requires "transition" or "system-level" experiments, which link laboratory and field studies. In the following work, we examined the aspects of ecosystem structure and function which are potentially the most sensitive indicators of ecosystem health. We also studied the distribution and partitioning of SRC components which are particularly useful in the design and validation of pathway models.

During FY 1981, four sets of artificial stream channels were designed and constructed (Figure 4). Columbia River sediments impregnated with SRC-II material at three concentrations, plus a control, were placed in the channels, and flowing Columbia River water was introduced. Specially designed glass habitat modules and diatometers served as substrates for biotic recruitment. Chemical sampling strategies for water and sediment were developed and tested.

Biot ic measurements, recorded at 12, 24 and 41 days, focused on four fundamental characteristics: community biomass; chlorophyll a; distribution and diversity of invertebrates; and relative abundance of algae. Statistical treatment of biotic data are in progress; however, certain preliminary observations on apparent effects $c$ an be made. Only in the high-concentration stream at day 41 did there appear to be a significant increase in community biomass (Figure 5). Trends in chlorophyll a generally reflected diatometer biomass patterns. Chlorophyll a was initially (day 12) depressed in the high-concentration stream but recovered by day 24 . No enhancement was observed at day 41. Distributions of invertebrates in water and sediment after 41 days suggested a reduction in total crop, reduction in diversity, and destruction of sediment habitats with increasing SRC concentration over the 41-day test period. The reduction in herbivorous insect larvae at higher concentrations may account for increased community biomass in the diatometers. Relative abundance of benthic algae is given in Table 4. Results suggests a generally normal succession over time in all streams. No significant variation in taxa composition was observed in any stream.

Chemical Characterizations. Flowing stream water was periodically sampled using a 1.0-L grab sample or 10.0 of $L$ water pumped through an XAD-resin absorption column. After 41 days, layers of sediment were sampled. Water samples were analyzed to determine levels of phenols and aromatic hydrocarbons, which are known to occur in aqueous extracts of SRC-II. Analysis of water samples is essentially complete. Analysis of the sediments will be a Fy 1982 task.

Levels of total phenols as determined by dye photometry in low-, middle- and highconcentration stream waters approached control values at days 2,7 , and 13 , respectively (Figure 6). However, a more detailed gas chromatographic analysis revealed elevated phenol levels in both high- and middleconcentration streams at least through day 21 , and in the low concentration stream through day 3 . Over 21 days, total phenols determined by gas chromatography in high- and middle-concentration streams ranged from $4200 \mathrm{ppb}$ to $24.4 \mathrm{ppb}$ and from $640 \mathrm{ppb}$ to 1.5 ppb, respectively. Low concentration stream values ranged from $141 \mathrm{ppb}$ to $0.1 \mathrm{ppb}$ over 5 days. The phenolic composition of all waters varied with time. Absolute levels of all 

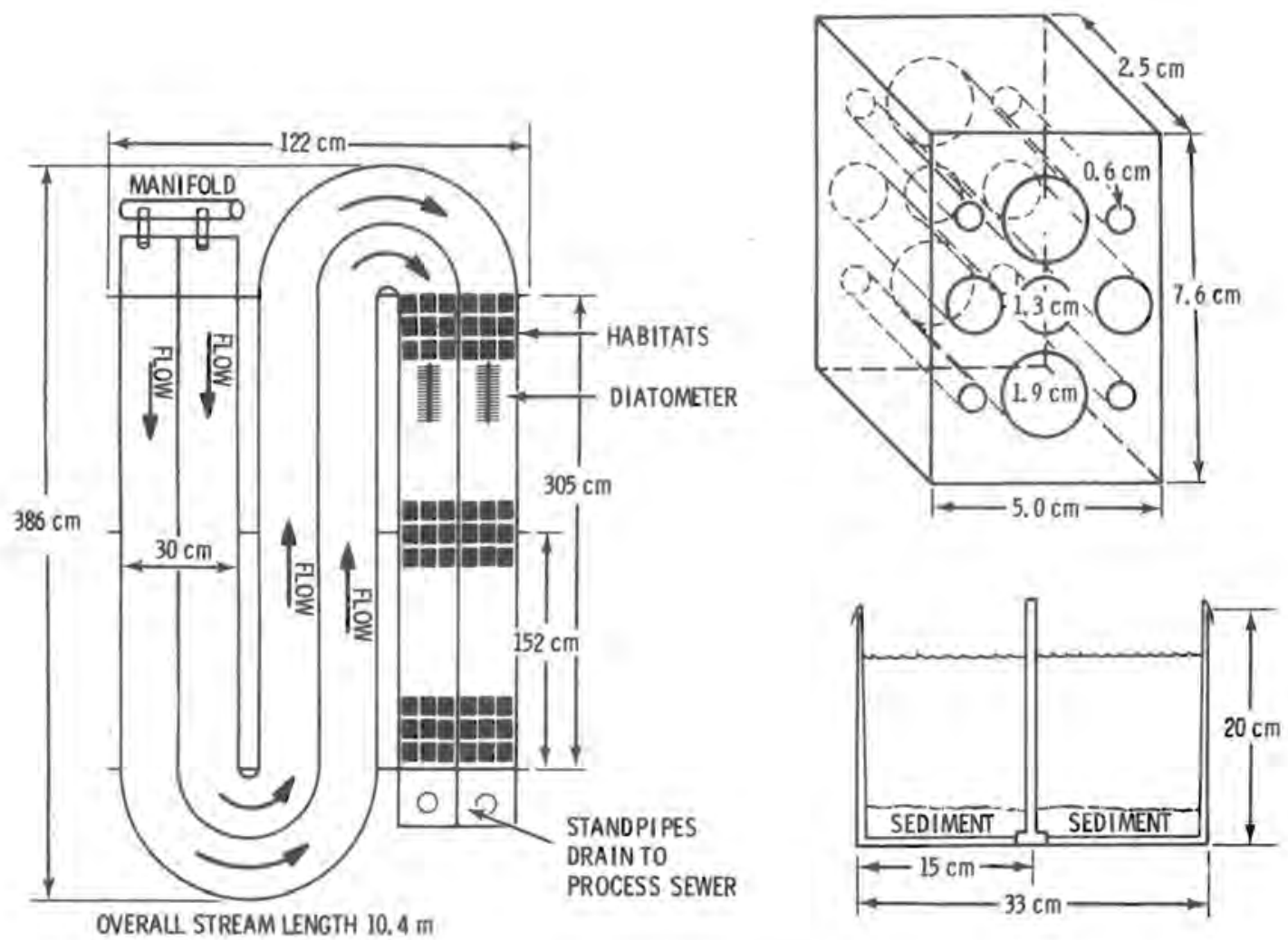

FIGURE 4. Artificial Stream Channels and Macroinvertebrate Habitate Modules

phenol classes declined with time. Heavier, more lipophilic phenols gradually replaced the lighter, hydrophilic phenols (e.g., cresols) as the predominant species present (Figure 7).

Low levels of aromatic hydrocarbons occurred in high-, middle- and low-concentration streams over at least 31,5 and 3 days, respectively. Levels of total aromatics ranged from 326.8 to $8.5 \mathrm{ppb}, 119.9$ to $14.3 \mathrm{ppb}$, and 31.6 to $8.8 \mathrm{ppb}$, for high, middle and low concentrations, respectively. Analogous to the phenolic compositional change, the relative abundance of aromatic hydrocarbons changed over time with heavier, lipophilic aromatics (e.g., $C_{3}$ naphthalenes) replacing lighter, hydrophilic classes (e.g., naphthalene) as the predominant species (Figure 8 ).

\section{ENVIRONMENTAL PATHWAYS MODELING}

This task will assess the relative importance of major routes by which man and other organisms may be affected by coal synfuels mate- rials. It will also help prioritize and evaluate the adequacy of research. Ultimately, this effort will provide a tool for predicting levels of exposure to man and his resource species from synfuels materials delivered through various enviromental routes.

A literature search was initiated to provide background information on aquatic pathways from chemical releases. The search provided data on uptake, clearance, and bioaccumulation of chemicals by aquatic life. Soil sorption, microbial degradation, photolysis and evaporation were also included in the literature search. The information was used to develop a computer code that mathematically models the fate of chemical by-products of the coal liquefaction process. The computer program, known as the Aquatic Pathways Model (APM), is being developed specifically to model the fate of a chemical species in the aquatic environment. Ultimately, the program calculates the concentration of a selected chemical species in water, in the sediment, and in fish, and uses this information to determine the bioaccumulation factor in fish. The program uses 


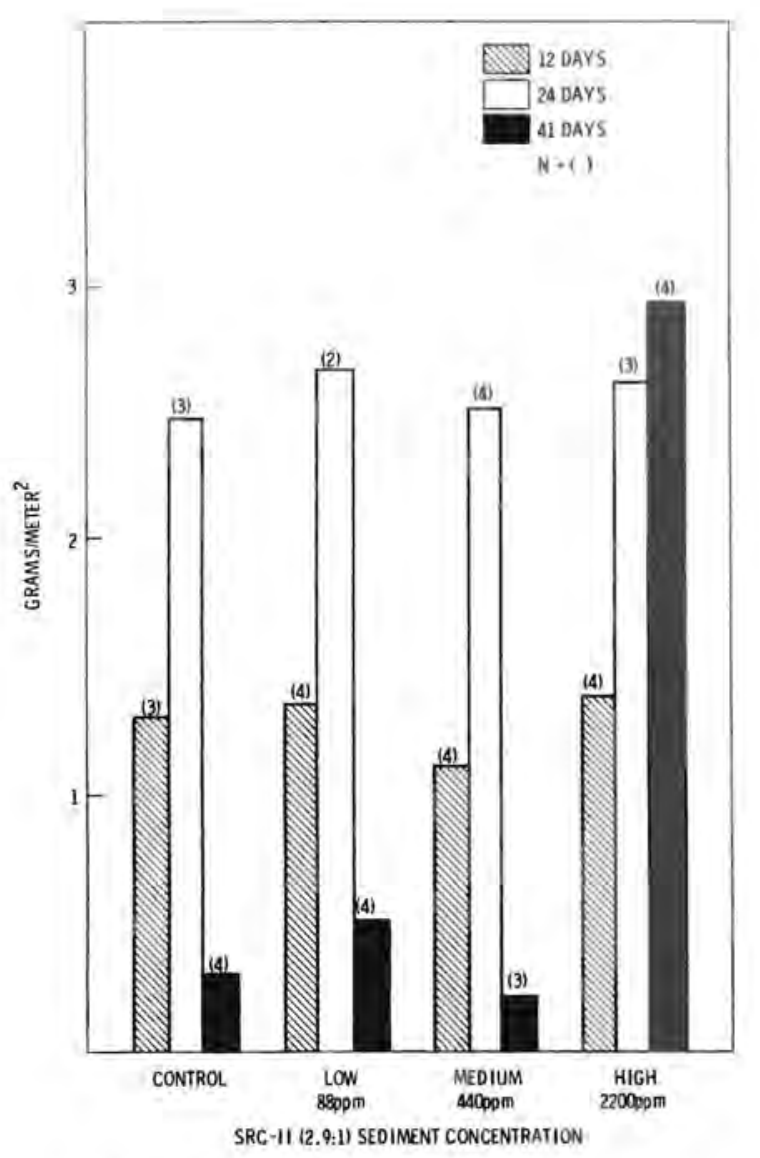

FIGURE 5. Diatometer Community Biomass

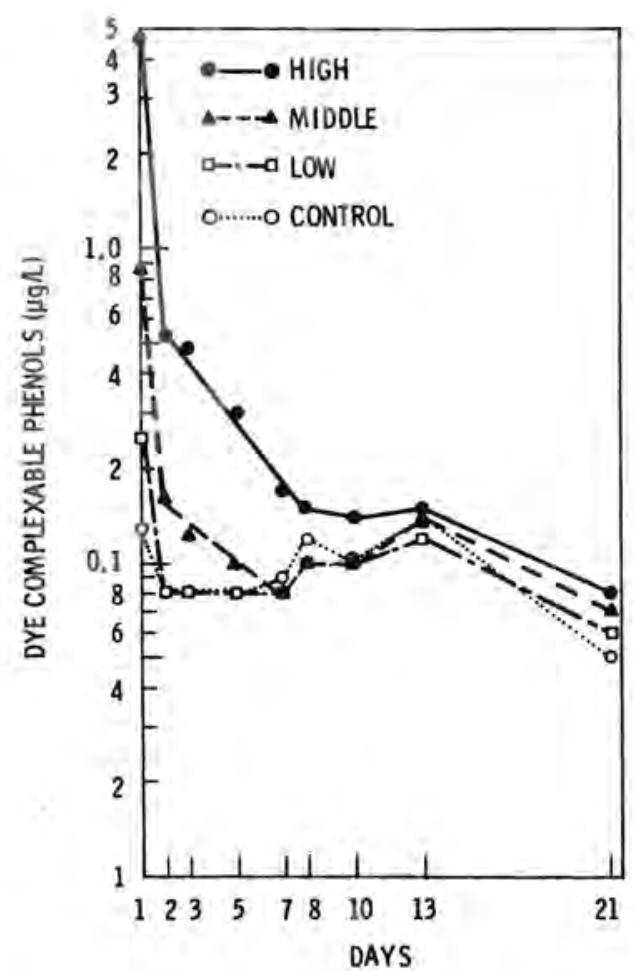

FIGURE 6. Concentrations of Dye-Complexable Phenols in Artificial Streams

TABLE 4. Percent Abundance of Benthic Algae Taxa Amounting to at Least $1 \%$ of Total

Concentration at Day $12 \quad$ Concentration at Day $24 \quad$ Concentration at Day 41

Taxa Control Low Medium High Control Low Medium(a) High Control Low Medium(a) High

Asterionella formosa

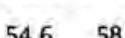
Medium

Pennate Diatoms Synedra spp

Fragilaria spp.

Melosira spp.

Cymbella spp.

Creens

Comphonema spp.

Centrate Diatoms

Epithemia sp.

Mongeotia sp.

Stigeoclonium

Ankistrodesmus sp.

$54.6 \quad 58.2$

$\begin{array}{ll}8.7 & 12.7\end{array}$

$8.7 \quad 12.7$

$5.7 \quad 5.3$

50.3

9.2

9.2
9.2

6.2

$\begin{array}{lll}49.2 & 44.9 & 42.3\end{array}$

$14.1 \quad 24.4$

14.1

$3.9 \quad 3.3$

5.9

$\begin{array}{ll}9.9 & 8.8\end{array}$

$\begin{array}{lll}4.2 & 10.3 & 24.6\end{array}$

$\begin{array}{rrr}4.2 & 10.3 & 24.6 \\ 1.6 & 5.3 & 5.5\end{array}$

$\begin{array}{ll}1.7 & 2.6\end{array}$

2.9

$\begin{array}{lll}2.9 & 1.8 & 2.1\end{array}$

$1.1 \quad 1.0$

(b)

$1.6-$

$=-\overline{10}$

1.1

- - -

-

$-$

- - - -

$\overline{-}$

ב

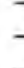

Anabaena spp.

$-\quad-$

(a) $n=1$.

(b) No data. 


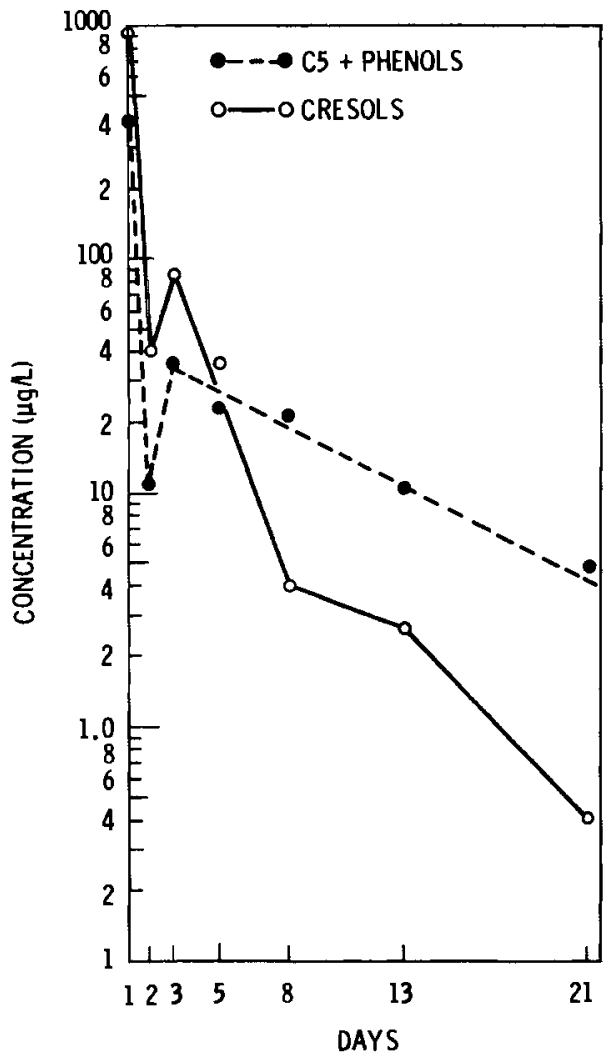

FIGURE 7. Concentrations of Cresols and $\mathrm{C}_{5}+$ Phenols in the High-Concentration Stream

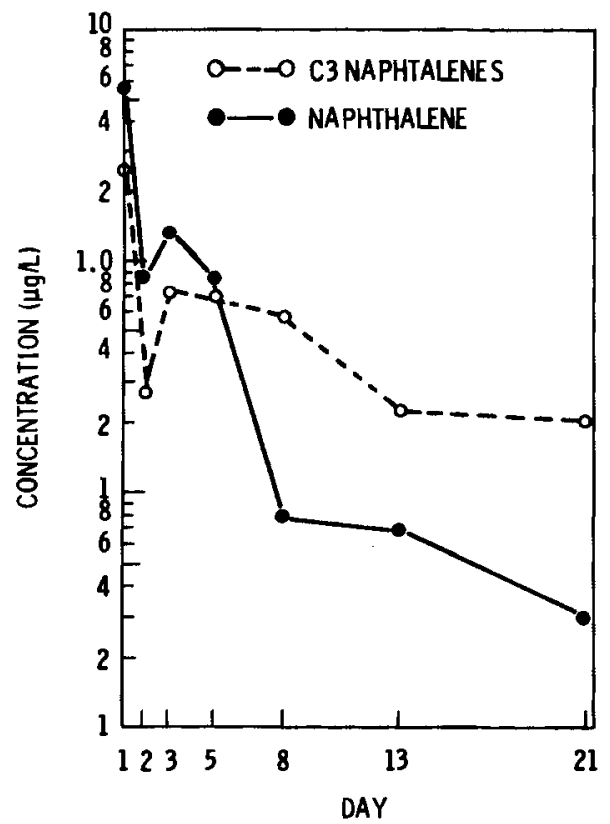

FIGURE \&. Concentrations of Naphthalene and $\mathrm{C}_{3}$ Naphthalenes in the High-Concentration Stream compartmental analysis to model either a static or flowing aquatic system. The theoretical model of the system as it is programmed is displayed in Figure 9.

The model is designed to simulate the fate of a chemical species in an aquatic environment based solely on the physical properties of the chemical. The properties currently analyzed by the program are water solubility, vapor pressure, molecular weight, and the temperature at which these properties apply. The program uses these properties to develop transfer rates $(K)$ between the various compartments (Q). When experimental transfer rate constants are known, they can be used in the program to achieve more accurate results.

The aquatic pathways model was patterned after published work so that a comparison of results could be made to determine the validity of the model. Initial tests of the program were made with the chemical chlorpyrifos, because sufficient information was available on that chemical to test the accuracy of the code. Results of the model execution compared favorably with published computer simulations.

With this indication that the computer code was functioning properly, attention was focused on the fate of phenolic compounds. Phenols were investigated first because they constitute the largest part of the water-soluble fraction (WSF) of coal liquids, and because they are extremely toxic to aquatic life.

Through a literature search, a substantial amount of chemical data necessary to evaluate the phenols present in the water-soluble fraction of coal liquids was collected. The data were scattered throughout the literature and were based on a wide variety of experimental conditions. Consequently, initial simulations with the APM model were difficult; however, we were able to draw some tenative conclusions on the behavior of phenolic compounds based on both a synthesis of the literature and simulation modeling.

Generally, once phenols gain entry to the environment, they will be decomposed rapidly by microbial action. Bacteria have been shown to break down phenol, cresols, xylenols (dimethyl phenols), 3 ethyl 5 methyl phenol, $2,3,5$ methyl phenol and chlorophenols. The major pathway followed by cresol in an aquatic system appears to be microbial degradation. This pathway is dependent upon the type of water body into which the compound is introduced. If there is a body of water with a high bacterial count such as a pond or eutrophic lake, the half-lives of phenolic compounds appear to be very short (in the range of hours). In 


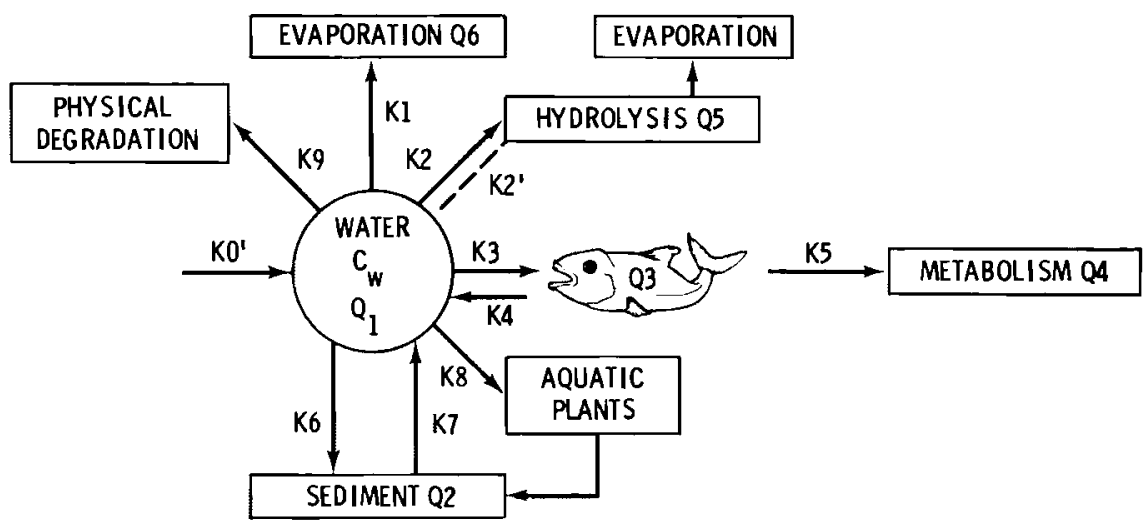

FIGURE 9. Aquatic Pathways Model (APM)

a body of water devoid of bacteria, this pathway is not a major factor, and other pathways such as photolysis and evaporation appear to be principal pathways. Simulation modeling al so suggested that microbial degradation is a major pathway for the removal of cresol.

The current investigation has also shown that relatively water-soluble phenolic compounds do not behave as predicted in correlations based on less water-soluble pesticides. The octonol-water partition coefficients ( $\left.K_{0 w}\right)$ predicted for phenols are much lower than experimental values. The $K_{0 w}$ 's for phenolic compounds of interest are generally not within range of values that have been corrected with bioconcentration factors (BCF). However, we have not yet tested the correlation between Kow's and BCFs for these compounds. Because these predictive correlations are not valid for phenolic compounds, it would be useful to have fish bioaccumulation data for more chemicals of the phenolic group. At present, we have data on the bioaccumulation of three phenolic compounds in $f$ ish: phenol; 2,4,5 trichlorophenol; and pentachlorophenol. Additional information on structure-activity relationships of phenols is required. 


\title{
- Coal Liquefaction Health and Environmental Effects Document (HEED)(a)
}

\author{
Principal Investigator: P. J. Mellinger
}

The goal of health and environmental effects assessments is to provide a substantive basis for identifying environmental research and development needs and priorities contained in environmental development plans and for judgments regarding environmental readiness of developing technologies. The assessments provide a basis for establishing safety guidance for DOE activities, for evaluating occupational health and safety regulations and overview of control technology, and assist in the justification and prioritization of control technology development

The coal liquefaction Health and Environmental Effects Document (HEED) is a health and environmental risk analysis providing an improved basis for formulating and implementing statutes designed to control environmental impacts and ensure the establishment of environmentally acceptable technologies. The procedure by which these effects are analyzed is necessarily iterative. The first iteration focuses on the coal liquef action facility, one pollutant it might produce, and one pathway of exposure. The first iteration is called a zero-order assessment. Ecological/ environmental effects and additional health effects (i.e., food chain exposure) will be considered in later iterations of the HEED documentation.

The FY 1981 effort concerned such an zeroorder assessment and examined the occupational and public health effects that may result from the exposure to nonmethane hydrocarbons (NMHC), which according to one scenario scheduled for deployment in 1992, may be released from a direct coal liquefaction industry.

(a) This program is sponsored by the Health and Environmental Risk Analysis. Program of the Office of Health and Environmental Research
Hydrocarbons have long been suspected as contributors to carcinogenicity in humans. A wide range of NMHC are produced and released to the environment from conventional coal utilization processes. Epidemiological studies of workers employed in these processes, which have been ongoing for several decades, indicate that prolonged exposure to the MNHC in coal-derived liquid volatiles, coke oven emissions, coal tar products and asphalt fumes can result in increased rates of cancer of the skin, lungs, scrotum and other organs. However, the specific chemical components of the MNHC that are responsible for this increased risk have not been ident ified and, therefore, no dose-response relationship relative to specific chemicals has been established.

By using the extensive epidemiological data base for coke oven workers and by correlating coke oven dose-effect estimates for hydrocarbon releases of NMHC, health effects may be quantifiable. These assumptions estimate $1.2 \times 10^{-3}$ cancer deaths per year to the 1992 industrial work force of 6500 workers and $5 \times 10^{-2}$ cancer deaths per year to the U.S. public after the appropriate latency periods. 

Nuclear Waste:

Fission 


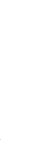




\section{NUCLEAR WASTE: FISSION}

- Transuranic Element Behavior in Soils and Plants

- Transuranic Chemical Species in Ground Waters

- Quantitative Aspects of Transuranic and other Radionuclide Field Studies

- Analog Elements for Transuranic Chemistries

- Long-Term Plant Availability of Actinides

- Radioecology of Nuclear Fuel Cycles

- Environmental Behavior and Effects of Technetium-99 and lodine-129

One of the highest priorities in the continued development and use of fission as a source of energy is the resolution of questions about the fate and ultimate effects of long-lived radionuclides in the biosphere. The individual studies described in this section represent a multiproject program. They range from investigations of the behavior and effects of long-lived nuclides at the chemical and cellular level to ecosystems which describe inventory, transport, and effects in waste management areas.

In terrestrial studies, investigations have demonstrated the importance of valence state, complexation, competing elements, microbial processes, redistribution in the soil profile, and weathering cycles in governing the availability of selected actinide elements (plutonium, americium, neptunium, uranium) and fission products (129/ and ${ }^{99} \mathrm{Tc}$ ) to plants and to the consuming animals. In the case of plutonium, it was demonstrated that ingestion of plant tissues containing plutonium may result in greater transfer across the gut compared to gavaging animals that were fed inorganic plutonium solutions. The technetium in plant tissues is less available to animals but is associated with the S-cycle in biota and accumulated in poultry eggs. This underscores the importance of detailed studies of soil, plant and animal factors influencing uptake by the ingestion pathway.

Radioecological field studies were directed toward development of innovative techniques for establishing ecological dosimetry and establishing pertinent ingestion pathways and exposure levels through description of habitat types, population densities, and, in several instances, dosimetry, for major insects, reptiles, birds and mammalian species in reactor and waste management areas. 


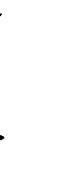




\title{
- Transuranic Element Behavior in Soils and Plants
}

\author{
Principal Investigator: R. E. Wildung
}

Associate Investigators: T. R. Garland, D. A. Cataldo, J. E. Rogers, K. M. McFadden, E. A. Jenne and R. G. Schreckhise

The principal objective of this study is to define soil, plant, and foliar interaction processes that influence the availability of transuranic elements to agricultural plants and animals as a basis for improved modeling and dose-assessment. Major areas of emphasis are: 1) soil and soil-microbial processes that influence the concentration and form of transuranic elements in soil solutions and availability to the plant root with time; 2) deposition and plant interception of airborne submicronic particles containing transuranic elements and their susceptibility to leaching; 3 ) plant processes that influence transport across plant root membrane and foliar surfaces, as well as the form and sites of deposition of transuranic elements in mature plants; and 4) the integrated effect of soil and plant processes on transuranic element availability to, and form in, animals that consume plants.

\section{INFLUENCE OF NEPTUNIUM CONCENTRATION ON PLANT AVAILABILITY}

Among the actinides, plutonium and neptunium represent extremes in both chemical and biological behavior. Emphasis in this program to date has been on plutonium. Chemically, $\mathrm{Pu}^{+4}$ predominates in soils and plants. Since this form is prone to hydrolysis in aqueous systems, its transfer from soils to plants to animals is comparatively restricted. Concentration ratio (CR) values from soils to plants range from $10^{-4}$ to $10^{-2}$, with the fractional transfer from plants to animal ranging from $10^{-4}$ to $10^{0}$. Chemically, neptunium $c$ an be maintained in aqueous solution as $\mathrm{Np}^{+5}$, and is not particularly prone to hydrolysis. Values for concentration ratios (soils to plants) can range from $10^{-3}$ to $10^{-1}$. However, without exception, CR data has been obtained using soils amended with $237 \mathrm{~Np}$ at concentrations in excess of $0.4 \mathrm{\mu g} / \mathrm{g}$ soil in order to optimize detection, which is -4 to 5 orders of magnitude higher than calculated, near-term soil levels. Although animal ingestion studies are limited, the fractional adsorption of neptunium is $-10^{-2}$. Since the available information suggests that neptunium is substantially more bioavailable than plutonium, it is essential that a clear understanding of important parameters be developed. Methodology developed on plutonium as a part of this program is now being applied to provide this information.

As a first phase in defining the behavior of neptunium, the effect of $\mathrm{Np}^{+} 5$ concentration on root adsorption, uptake (absorption) by roots, and transfer from root to shoot was determined using $235 \mathrm{~Np}$ and $237 \mathrm{~Np}$. Hydroponically grown, 11-day-old soybean plants were placed in a solution containing $2.5 \times 10^{-3}$ to $8.5 \times 10^{5} \mathrm{ng} / \mathrm{ml}$ of $\mathrm{NpO}_{2}^{+1}$ for 24 hours. Figure 1 shows the shows the effect of concentration on the fraction of neptunium adsorbed to roots and absorbed into tissues (curve $A$ ) and the fraction of the total removed from solution which was in the plant (curve B). The fraction of neptunium removed by adsorption and absorption increases from $4 \%$ at $10^{-3} \mathrm{ng} / \mathrm{ml}$ to $20 \%$ at $2 \times 10^{-2} \mathrm{ng} / \mathrm{ml}$, decreases to $6 \%$ at $3 \times 10^{2} \mathrm{ng} / \mathrm{ml}$ and exhibits a rapid increase to $\sim 80 \%$ at solution concentrations $>4 \times 10^{2} \mathrm{ng} / \mathrm{ml}$. The fraction of neptunium adsorbed and actually absorbed (curve B) generally decreased from $58 \%$ to $0.5 \%$ over the 9

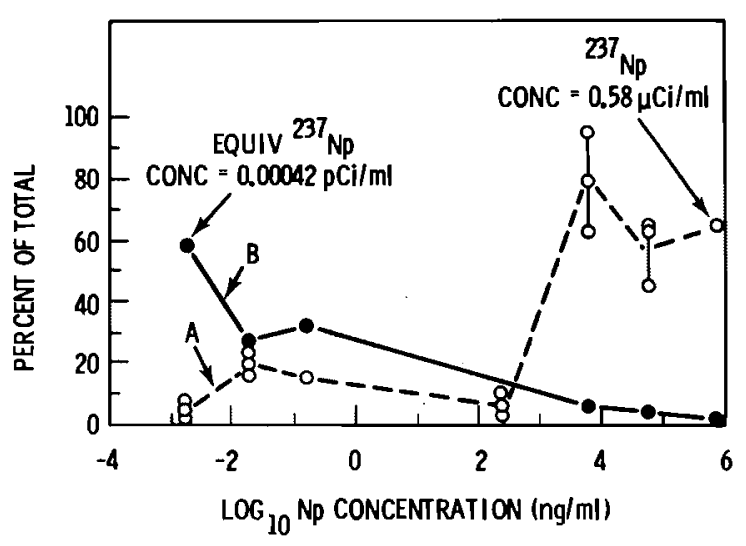

FIGURE 1. Neptunium Uptake by Roots and Shoots as a Function of Neptunium in Concentration in Solution and Leaves. Curve $A$ denotes the fraction adsorbed to root surface and fraction absorbed into root and shoot. Curve $B$ denotes the fraction of $A$ absorbed into plant root and shoot. 
orders of concentration. Although the relationship between concentration, adsorption, and absorption is complex, the data suggest that the processes involved in physical adsorption and absorption are affected by concentration. Absorption predominates at low neptunium concentrations and physical adsorption predominates at concentrations in excess of $4 \times 10^{2} \mathrm{ng} / \mathrm{ml}$.

While it was not the purpose of this study to assess the effect of concentration on CR values, any experimental parameter that affects physical and biological processes, as concentration does, will affect CR values. This is better illustrated by plotting solution concentration against the fraction of adsorbed neptunium (root plus shoot), which is transported from root to shoot (Figure 2). At concentrations below $2.5 \times 10^{-2} \mathrm{ng} / \mathrm{ml}$ and above $8 \times 10^{3} \mathrm{ng} / \mathrm{ml}$, an increased fraction of neptunium was transported to shoots, while between these concentrations the fraction transported was relatively constant at $\sim 10 \%$. Based on data from Figures 1 and 2 , it may be speculated that at low neptunium concentrations $\left(<2.5 \times 10^{-2} \mathrm{ng} / \mathrm{ml}\right)$, where adsorption predominates over adsorption, adsorption is efficient and the mass of neptunium passing into metabolic compartments of the root is not in excess of that transported. The result is an efficient transfer of neptunium to the shoot. At concentrations between $2.5 \times 10^{-2}$ and $8 \times 10^{3} \mathrm{ng} / \mathrm{ml}$, the mass exceeds transport capacity and a fraction is partitioned to other components, possibly to storage components. (This partitioning is known to occur for both nutrient and nonnutrient ions.) At concentra-

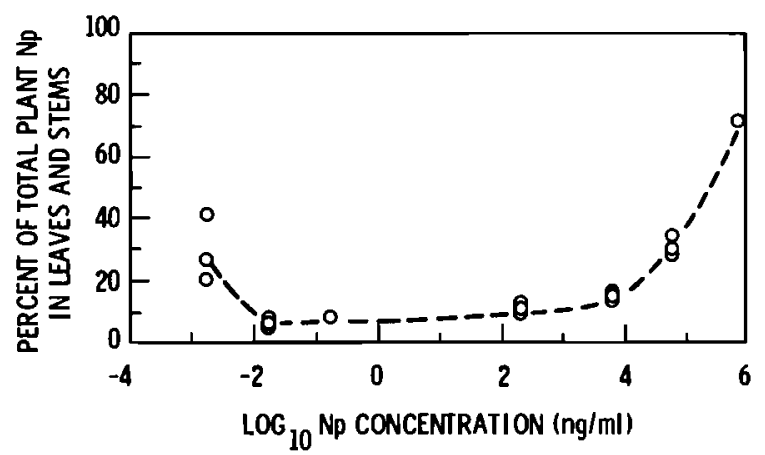

FICURE 2. Neptunium Uptake by Leaves and Stems as a Function of Neptunium in Solution tions in excess of $8 \times 10^{3} \mathrm{ng} / \mathrm{ml}$, the mass of neptunium passing through the root may exceed storage or metabolism capacity (which is also known to occur when physiological concentrations are exceeded), and transport from root to shoot is increased. Since this is in the range of soluble neptunium for most studies with $237 \mathrm{~Np}$, the effect of neptunium soil concentration on $C R$ value is currently being evaluated.

\section{PLANT METABOLISM OF NEPTUNIUM IN SOYBEAN AND ALFALFA}

Previous studies with $\mathrm{Pu}\left(\mathrm{NO}_{3}\right)_{4}$ have shown that $>99 \%$ of the plutonium in soybean and alfalfa is found in the root and $<1 \%$ is transported to shoot tissues. The soluble fraction of leaves and roots contained -65 and $25 \%$ of the total plutonium present, respectively. In both tissues, $>85 \%$ of the soluble plutonium was associated with $>10,000$ molecular weight components. Under similar conditions, allowing 5 days for metabolism, the metabolic behavior of $\mathrm{Np}^{+5}$ in both soybean and alfalfa was substantially different (Table 1). In leaves of both species, $-65 \%$ of the neptunium was present in soluble components, which is similar to measurements made for plutonium and reported previously. However, roots of soybean and alfalfa contained on 1 y $16 \%$ and $2.5 \%$, respectively, of the neptunium in solubles. This is substantially lower than the $-25 \%$ observed for plutonium. A relatively large fraction of neptunium in soybean roots is associated with the organelle fraction. While no explanation is currently available, associations with specific organelles are currently being investigated. Molecular weight distributions for neptunium are markedly different than those observed for plutonium. In general, $<40 \%$ of the soluble neptunium is associated with $>10,000 \mathrm{MW}$ solubles (compared with $>85 \%$ for plutonium), while $>50 \%$ of the soluble neptunium is associated with $<5,000 \mathrm{MW}$ components. As in the case with plutonium, $-35 \%$ of the neptunium is associated with low molecular weight components (<500 MW) in the stem and probably represent transport forms.

In the case of plutonium, plant metabolism and associated complexation processes may result in an increase in gastrointestinal transfer of plant-incorporated neptunium compared with inorganic forms. Animal ingestion studies with plant-incorporated neptunium are currently underway. 
TABLE 1. Chemical Fate of ${ }^{235} \mathrm{~Np}$ in Tissues of Soybean and Alfalfa. Measurements are given in \%.

\begin{tabular}{|c|c|c|c|c|c|}
\hline \multirow[b]{2}{*}{ Plant Species(a) } & \multirow[b]{2}{*}{ Total Distribution } & \multicolumn{4}{|c|}{ Molecular Weight Distribution for Solubles } \\
\hline & & $>10,000$ & $10,000-5,000$ & $5,000-500$ & $<500$ \\
\hline $\begin{array}{l}\text { Tissue and Fracti } \\
\text { Soybean } \\
\text { Leaves } \\
\text { Residue } \\
\text { Organelles } \\
\text { Solubles }\end{array}$ & $\begin{array}{r}22.5 \pm 3.5 \\
9.5 \pm 2.8 \\
67.9 \pm 2.8\end{array}$ & $39.6 \pm 1.8$ & $7.5 \pm 0.5$ & $28.1 \pm 1.4$ & $24.8 \pm 2.7$ \\
\hline $\begin{array}{l}\text { Root } \\
\text { Residue } \\
\text { Organelles } \\
\text { Solubles }\end{array}$ & $\begin{array}{l}42.9 \pm 2.2 \\
40.7 \pm 2.2 \\
16.4 \pm 0.0\end{array}$ & $32.9 \pm 2.1$ & $18.4 \pm 1.7$ & $21.4 \pm 0.8$ & $27.3 \pm 1.1$ \\
\hline $\begin{array}{l}\text { Alfalfa } \\
\text { Leaves } \\
\text { Residue } \\
\text { Organelles } \\
\text { Solubles }\end{array}$ & $\begin{array}{r}25.2 \pm 1.9 \\
7.3 \pm 1.8 \\
67.5 \pm 0.1\end{array}$ & $36.0 \pm 3.3$ & $7.9 \pm 0.2$ & $41.5 \pm 0.9$ & $14.5 \pm 2.1$ \\
\hline $\begin{array}{l}\text { Stem } \\
\text { Residue } \\
\text { Organelles } \\
\text { Solubles }\end{array}$ & $\begin{array}{r}47.3 \pm 6.0 \\
2.1 \pm 0.7 \\
50.5 \pm 3.9\end{array}$ & $19.6 \pm 6.1$ & $3.6 \pm 0.7$ & $41.0 \pm 7.3$ & $35.7 \pm 4.3$ \\
\hline $\begin{array}{l}\text { Root } \\
\text { Residue } \\
\text { Organelles } \\
\text { Solubles }\end{array}$ & $\begin{array}{r}93.7 \pm 1.1 \\
5.2 \pm 0.3 \\
2.5 \pm 0.0\end{array}$ & $30.3 \pm 7.3$ & $6.1 \pm 0.6$ & $46.8 \pm 12.6$ & $16.6 \pm 4.8$ \\
\hline
\end{tabular}



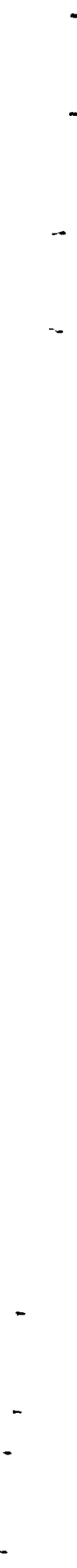


\title{
- Transuranic Chemical Species in Ground Waters
}

\author{
Principal Investigators: D. E. Robertson and K. H. Abel
}

One of the major gaps in understanding the environmental behavior of long-lived radionuclides is an adequate knowledge of the mechanisms by which these radionuclides can become mobilized and transported in ground waters. At the Hanford $\mathrm{N}$-Reactor site, a unique ground-water microcosm allows us to study the physicochemical processes that control the mobility of radionuclides in ground waters. The system is being used as a natural laboratory to identify specific forms of the transuranic radionuclides that migrate in ground water and to determine the rates and mechanisms controlling this migration. During the past year, the ionic species and oxidation states of plutonium in the ground water from the 1301-N Trench have been determined.

At the Hanford $\mathrm{N}$-Reactor site, low levels of radioactivity contained in aqueous effluents from the $\mathrm{N}$-Reactor are continually discharged at a rate of approximately 3 million gallons per day to a rock-lined crib and overflow seepage trench located on a bluff overlooking the Columbia River (Figure 1). The effluent water percolates by gravity through a soil bank, and some of the water emerges to form seepage springs located along the bank of the Columbia River directly below the crib-trench.

During the 18 years of operation of the $100-\mathrm{N}$ Reactor, over 8000 curies of long-lived fission and activation products have been discharged to the 1301-N Trench, including over 12 curies of 239-240pu. Most of these radionuclides have been retained in the soil bank between the trench and the Columbia River. However, unique mobile chemical forms of a number of the radionuclides, including traces of plutonium, have been observed to migrate in the ground water at this site.

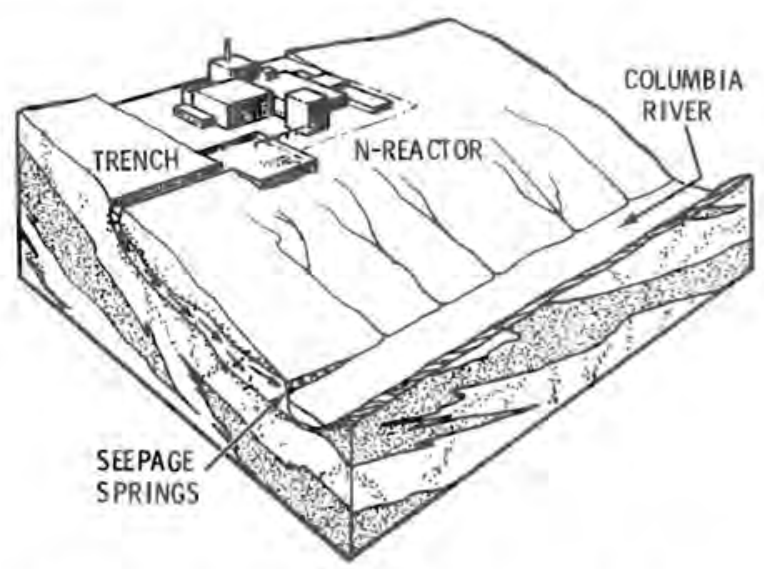

FICURE 1. Schematic Cross-Sectional View of $\mathrm{N}$-Reactor Liquid Effluent Disposal System
In order to characterize the movement of plutonium in the 1301-N ground water, a series of field experiments was performed to determine the oxidation states and ionic forms of the mobile plutonium species. Samples of trench inlet water and seepage spring water were measured for plutonium species in the upper oxidation states (Pu V-VI), and in the lower oxidation states (PU III-IV). The procedure developed by Nelson and Lovett for determinng oxidation states of plutonium in Irish Sea water was employed. This method is based on the classical differentiation of $\mathrm{Pu}(\mathrm{III})$ and $\mathrm{Pu}(\mathrm{IV})$ from $\mathrm{Pu}(\mathrm{V})$ and $\mathrm{Pu}(\mathrm{VI})$ by co-precipitation of the former pair on $\mathrm{NdF}_{3}$. Two $25-\mathrm{L}$ samples of $0.4 \mu-f i 1$ tered spring water were spiked with 236pu(IV) and 242pu(VI) tracers and reagents added to the samples to give a final solution of $0.8 \mathrm{M}$ in $\mathrm{HNO}_{3}, 0.25 \mathrm{M}$ in $\mathrm{H}_{2} \mathrm{SO}_{4}, 0.0005 \mathrm{M}$ in $\mathrm{K}_{2} \mathrm{Cr}_{2} \mathrm{O}_{7}$ and $0.0007 \mathrm{M}$ in $^{-}$ $\mathrm{Nd}\left(\mathrm{NO}_{3}\right)_{3}$. After standing for several hours, the water was made $0.25 \mathrm{M}$ in $\mathrm{HF}$ and the resultant $\mathrm{NdF}_{3}$ [containing the $\mathrm{Pu}(\mathrm{III})$ and $\mathrm{Pu}(\mathrm{IV})$ ] was removed by filtration. Twenty-five $g$ of $\left(\mathrm{NH}_{4}\right)_{2} \mathrm{SO}_{4} \mathrm{FeSO}_{4} \quad 6 \mathrm{H}_{2} \mathrm{O}$ was added to the $\mathrm{fil}_{1}-$ trate, and the water was allowed to stand overnight to allow reduction of oxidized plutonium species to Pu(III) and Pu(IV). Another $500 \mathrm{mg}$ of $\mathrm{Nd}\left(\mathrm{NO}_{3}\right)_{3}$ was added, and the resulting $\mathrm{NdF}_{3}$ was again removed by filtration. The plutonium in each $\mathrm{NdF}_{3}$ precipitate was purified by routine ion exchange techniques and electrodeposited on stainless steel counting discs. The samples were counted on silicon diode alpha spectrometers for several thousand minutes. The results are presented in Table 1.

The plutonium species in the inlet water to the trench and in the seepage springs are both in the higher ( $V$ and/or VI) oxidation states. The chemistry of these waters has been examined in detail and also support this observation. Using ion exchange experiments, the migrating plutonium species at the 1301-N site 
TABLE 1. Oxidation States of 239-240Pu Observed in N Springs and Crib Waters

\begin{tabular}{|c|c|c|c|}
\hline \multirow[b]{2}{*}{ Sample } & \multicolumn{2}{|c|}{$\begin{array}{c}\% \text { of } 239-240 \mathrm{Pu} \text { in Various } \\
\text { Oxidation States }\end{array}$} & \multirow{2}{*}{$\begin{array}{c}\text { Total } 239-240 \mathrm{Pu} \\
\text { Concentra- } \\
\text { tion }(\mathrm{fCi} / \mathrm{L}) \\
\end{array}$} \\
\hline & $\mathrm{Pu}(\mathrm{III}+\mathrm{IV})$ & $\underline{P U(V+V I)}$ & \\
\hline $\begin{array}{l}\text { Irench Water } \\
\text { March 3, } 1981 \\
\text { June 17, } 1981\end{array}$ & $\begin{array}{l}8-10 \\
8-9\end{array}$ & $\begin{array}{l}90-92 \\
91-92\end{array}$ & $\begin{array}{l}54,200-57,700 \\
23,600-28,500\end{array}$ \\
\hline $\begin{array}{l}\text { Spring Waters } \\
\text { September 24, } 1979 \\
\text { March 3, } 1981 \\
\text { June 17, } 1981\end{array}$ & $\begin{array}{r}11-20 \\
11-13 \\
3-14\end{array}$ & $\begin{array}{l}80-89 \\
87-89 \\
86-96\end{array}$ & $\begin{array}{c}22.4-102 \\
7.9-10.3 \\
49.7-300\end{array}$ \\
\hline
\end{tabular}

have been shown to be in an anionic form. Previous thermodynamic assessments of solid phase-soil solution equilibria in oxidizing media by Rai and Serne would suggest that a complex ion such as $\mathrm{PuO}_{2} \mathrm{CO}_{3} \mathrm{OH}^{-}$is the predominant species, which would be in accordance with our empirical data.

Currently, we are investigating the roles of micro-particulates and dissolved organic carbon compounds as carriers of transuranic radionuclides in ground waters. We are also studying the mechanisms of radionuclide attachment to soils as a function of distance from the trench. 


\title{
- Quantitative Aspects of Transuranic and Other Radionuclide Field Studies
}

\author{
Principal Investigator: R. O. Gilbert
}

Associate Investigators: J. C. Simpson and R. R. Kinnison

The purpose of this project is to identify, develop, and communicate statistical methodology for environmental actinide studies. Significant accomplishments for FY 1981 included continued publication of TRAN-STAT (a periodical specializing in the statistical aspects of environmental contaminant studies), continued work on our computer simulation study for evaluating ratios, and review of statistical methodology applicable to environmental radionuclides. Related work for the DOE Division of Office of Operational Safety included writing the statistical portion of a decommissioning and decontamination guide, expanding our expertise in Kriging and other spatial pattern statistical methodology applicable to the evaluation of potential environmental hazards, continuing statistical support for the Nevada Applied Ecology Group (NAEG), and providing statistical assistance to PNL's environmental radiological monitoring effort.

TRAN-STAT: STATISTICS FOR ENVIRONMENTAL CONTAMINANT STUDIES

TRAN-STAT is a periodical distributed by Pacific Northwest Laboratory (PNL) to DOE and DOE-contractors engaged in envionmental actinide studies. It is a tool for communicating statistical design and analysis techniques applicable to environmental studies, and helps stimulate the use of better statistical methodology in evaluating potential health hazards to man from the presence of radionuclides and other contaminants in the environment. Sixteen issues have been distributed thus far; four were published during FY 1981. Issue number 13, written by Madaline Barnes, was a discussion of the use of Kriging for estimating the spatial distribution of radionuclides. Issues 14 through 16 constituted the first part of the first TRAN-STAT Special Series. Special Series are a new concept for TRAN-STAT, and are intended for those instances in which a topic is to be discussed in great detail or cannot be adequately covered in a single issue. The first special series is on the use of statistical extreme value theory in environmental radionuclide studies; it will be five issues in length and is being written by Dr. Robert Kinnison of PNL. In FY 1982 we plan to publish six issues of TRAN-STAT on a bi-monthly schedule. The first two issues are in the final stages of editing and will complete the extreme value special series. The third issue is also ready for publication and will be a discussion of how to find "hot spots." We have commitments from authors to write issues on nonlinear estimates, ratio estimators, and estimation of rate parameters.

\section{DECOMMISSIONING AND DECONTAMINATION GUIDE}

Madaline Barnes and Dick Gilbert contributed chapters to the DOE Decommissioning and Decontamination guide being prepared by Dr. Dale Denham of PNL. In addition, Madaline Barnes has assisted in the final editing and preparation for publication. The guide is scheduled to be released on September 30, 1981 .

\section{COMPUTER SIMULATION OF RATIO ESTIMATORS}

During FY 1981, Jeanne Simpson completed the computer simulations of the statistical properties of ratio estimators. We anticipate that her report will be available by the end of this calendar year. Results of her study, which will also be reviewed in an issue of TRAN-STAT, will be useful to DOE and DOEcontractors for estimating transfers of radionuclides from one ecosystem to another; for work using isotope ratios; and for isotope equilibrium studies. Results of the study indicate that some estimators are better than others when evaluated statistically.

The ratio estimators that were investigated consisted of four "standard methods" and five other methods which are to some degree "specialized". The standard methods were: 1) the slope of the standard regression model with the intercept equal to zero, 2) mean of the ratios, 3) ratio of the means, and 4) median of the ratios. The five "specialized" estimators were developed by: Tin (1965), Quenoville (1956), Ricker (1973), Jolicoeur and Heusner (1971) Creasy (1956), and Doctor and Gilbert (1977), respectively. These specialized estimators are described and their references cited in TRAN-STAT issue number 9 (PNLSA-8074). 


\section{OTHER ACTIVITIES}

Drs. Pierre Delfiner and R. 0. Gilbert have written a review article on Kriging statistics that has tentatively been accepted by the Journal of the American Statistical Association. Dr. Delfiner is now in the process of satisfying the journal's editorial and reviewer comments.

We are supplying the NAEG with statistical assistance and support in the design and analysis of environmental radionuclide studies. We have already received data for work in FY 1982 to be used in our Kriging computer program, BLUEPACK, to obtain spatial patterns of isotope inventories for NAEG.

BLUEPACK has also been used by Or. Pamela Doctor in DOE studies of groundwater hydrology problems associated with underground storage of nuclear waste. Or. Gilbert and Dr. Kinnison are assisting Or. Wally Weimer of PNL on a United Nuclear Corporation funded project studying the effectiveness of cleanup efforts following the Church Rock Mine mill-tailings spill.

We are also providing assistance to PNL's environmental monitoring efforts at the Hanford reservation, quality control at analytical laboratories effort, and efforts to evaluate new instrumentation for measurement of very low concentrations of radionuclides.

Dr. Richard Gilbert left in September 1981 for a year's sabbatical from PNL. During this time Dr. Richard Gilbert will continue his work on Quantitative Aspects of Plutonium Field Studies with an off site assignment to write a statistics book about applied environmental radionuclide studies.

On February 2 through 5, 1981, Madaline Barnes presented a 4-day short course, "Statistics and the Statistician in Nuc lear Site Decontamination and Decommissioning," which was held at PNL. 


\title{
- Analog Elements for Transuranic Chemistries
}

\author{
Principal Investigator: W. C. Weimer \\ Associate Investigators: J. C. Laul and J. C. Kutt
}

The analytical technique for measuring trace concentrations of the analog rare earth elements has been refined for optimal detection. The technique has been used to determine the rare earth concentrations in a series of geological and biological materials, including samples harvested from controlled lysimeter investigations. These studies have demonstrated that any of the trivalent rare earth elements may be used as analog elements for the trivalent transuranics, americium and curium.

\section{BEHAVIOR OF ANALOG AND TRANSURANIC ELEMENTS} IN THE ENVIRONMENT

The objective of this program is to examine the environmental behavior of selected naturally occurring analog elements and to use these observations to predict the long-term behaviors of the transuranic elements americium and curium. The predicted transuranic behavior will eventually be used to estimate soil-to-crop transfer and food-chain transport of americium and curium that have reached an environmental equilibrium condition. The ultimate objective is to estimate the dose-to-man that these radionuclides would represent. Thus far we have: evaluated the soil chemistries of the rare earth analog elements (especially the element neodynium); measured soil-to-crop transfer for several selected species; and established, planted and harvested a series of lysimeters that were amended with both analog and transuranic elements. The lysimeters are used to measure soil-to-plant transfer and evaluate the rates at which selected species approach the chemical behavior of the native analog elements.

Short-term investigations (up to several weeks for plant uptake studies) have proven that americium, curium and their natural analog elements behave identically in the study regimes. The same chemical forms of the rare earth and transuranic elements behave the same. In addition, the pool of natural rare earth analog elements that has been defined as being biologically available in soil systems behaves approximately the same as does a transuranic from another source (fallout $\left.241_{A m}\right)$ in soil-to-plant transfer. Thus, these analog elements are good predictors of the transuranic behaviors. Study of the transport of the analog elements, although difficult, is achievable. These data also suggest that the radionuclides originating from the fallout from atmospheric testing programs are themselves good predictors of the ultimate environmental behavior of radionuclides entering the environment from other sources. However, the extremely low levels of fallout transuranic elements in the environment make the study of their transport through the food chain extremely difficult.

Investigations currently in progress include: 1) the determination of rare earth concentrations in a few selected animal species and their controlled diets in order to evaluate the plant-to-animal transfer of the analogs; 2) continued analys is of pea samples grown on lysimeters that have previously been spiked with americium, curium, cesium, and neodymium isotopes to evaluate how the uptake of these elements varies with time; and 3 ) selective chemical leaching of soils from some of the lysimeters in order to evaluate the comparative geochemistries of the added elements and those of the naturally occurring analogs in the soil.

\section{RARE EARTH ELEMENT ANALYSIS BY RADIOCHEMICAL} NEUTRON ACTIVATION

The concentrations of the rare earth elements in biological materials are extremely low, at the ppb to ppt level. In order to measure these concentrations precisely in plant or animal samples, a very sensitive analytical technique has been developed and revised. Briefly, this technique is a neutron activation analysis in which the sample is irradiated, then fused with nonactivated rare earth element carriers. The rare earth elements are separated from the remaining ions in the sample, and the individual elements in this enriched rare earth fraction are quant ified by counting on a detector which has been selected to optimize detection of specif ic rare earths. After counting, the samples are reirradiated and recounted to determine the overall chemical yield for the inactive carriers, which had been added prior to the rare earth element group separation. 
TABLE 1. Comparison of LEPD, Normal Ge (Li) and Ge (Li)-Nal(tl) Noncoincidence Detections for Rare Earths

\begin{tabular}{|c|c|c|c|c|c|c|}
\hline \multirow[b]{2}{*}{ Isotope } & \multirow[b]{2}{*}{$\begin{array}{l}\text { Decay }(b) \\
\text { Interval } \\
\end{array}$} & \multirow[b]{2}{*}{$\mathrm{E}(\mathrm{keV})$} & \multicolumn{3}{|c|}{ Relative Intensity(a) } & \multirow[b]{2}{*}{$\begin{array}{l}\text { Favorable } \\
\text { Mode }\end{array}$} \\
\hline & & & LEPD & $\mathrm{Ge}(\mathrm{Li})$ & $\begin{array}{l}\mathrm{Ge}(\mathrm{Li}) \text { - Nal (TI) } \\
\text { Noncoincidence } \\
\end{array}$ & \\
\hline \multirow[t]{4}{*}{${ }^{140} \mathrm{La}$} & 1 & 329 & 0.36 & 0.61 & - & \\
\hline & & 487 & 0.10 & 1.0 & - & $\mathrm{Ge}(\mathrm{Li})$ \\
\hline & & 816 & - & 0.38 & - & \\
\hline & & 1596 & - & 0.73 & - & \\
\hline${ }^{141} \mathrm{Ce}$ & 3 & 145 & 1.0 & $1.0(13)(c)$ & $0.86(20)$ & Noncoincidence \\
\hline${ }^{143} \mathrm{Ce}$ & 1 & 293 & 0.53 & $1.0(2.0)$ & $0.68(3.2)$ & Noncoincidence \\
\hline${ }^{142} \mathrm{Pr}$ & 1 & 1576 & - & $1.0(2.0)$ & $1.1(5.0)$ & Noncoincidence \\
\hline \multirow[t]{2}{*}{${ }^{147} \mathrm{Nd}$} & 2,3 & 91 & 1.7 & $1.0(2.0)$ & $0.70(2.0)$ & LEPD \\
\hline & & 531 & - & $0.22(3.5)$ & $0.20(10)$ & \\
\hline \multirow[t]{3}{*}{${ }^{153} \mathrm{Sm}$} & 1,2 & 41 & 1.8 & 0.14 & - & LEPD \\
\hline & & 70 & 0.17 & $0.10(4.0)$ & $0.055(4.0)$ & \\
\hline & & 103 & 1.1 & $1.0(3.0)$ & $0.74(50)$ & Noncoincidence \\
\hline $152 \mathrm{mEu}$ & 1 & 842 & - & $1.0(5.5)$ & $0.70(10)$ & $\begin{array}{l}\mathrm{Ge}(\mathrm{Li}) \\
\text { Noncoincidence }\end{array}$ \\
\hline \multirow[t]{3}{*}{${ }^{152} \mathrm{Eu}$} & 3 & 122 & 0.92 & $1.0(17)$ & $0.20(6.0)$ & LEPD, Ge (Li) \\
\hline & & 344 & 0.26 & $0.44(30)$ & $0.16(30)$ & \\
\hline & & 1408 & - & $0.082(50)$ & $0.050(50)$ & \\
\hline${ }^{159} \mathrm{Gd}$ & 1 & 363 & 0.67 & $1.0(1.5)$ & $0.65(2.0)$ & $\begin{array}{l}\mathrm{Ge}(\mathrm{Li}) \\
\text { Noncoincidence }\end{array}$ \\
\hline${ }^{153} \mathrm{Gd}$ & 3 & 98 & 1.1 & $1.0(2.0)$ & $0.68(2.2)$ & All \\
\hline \multirow[t]{3}{*}{${ }^{160} \mathrm{~Tb}$} & 3 & 87 & 1.2 & 0.80 & - & \\
\hline & & 298 & 0.60 & 1.0 & - & Ge (Li) \\
\hline & & 879 & - & 0.42 & - & \\
\hline $166 \mathrm{Ho}$ & 1 & 81 & 1.4 & $1.0(3.0)$ & $0.65(3.0)$ & LEPD \\
\hline${ }^{177} \mathrm{Er}$ & 1 & 308 & 0.60 & $1.0(1.6)$ & $0.80(3.0)$ & Noncoincidence \\
\hline${ }^{170} \mathrm{Tm}$ & 3 & 84 & 1.3 & $1.0(2.8)$ & $0.80(4.0)$ & All \\
\hline \multirow[t]{2}{*}{${ }^{175} \mathrm{Yb}$} & 1,2 & 283 & 0.30 & $0.53(8.0)$ & $0.31(12)$ & \\
\hline & & 396 & 0.40 & $1.0(24)$ & $0.80(50)$ & Noncoincidence \\
\hline \multirow[t]{3}{*}{${ }^{169} \mathrm{Yb}$} & 3 & 63 & 3.0 & $1.4(5.0)$ & $0.35(3.0)$ & LEPD \\
\hline & . & 131 & 0.50 & $0.56(4.0)$ & $0.16(3.0)$ & \\
\hline & & 177 & 0.67 & $1.0(8.0)$ & $0.50(8.0)$ & $\mathrm{Ge}(\mathrm{Li})$ \\
\hline $17 \mathrm{Lu}$ & 1,2 & 208 & 0.71 & $1.0(9.0)$ & $0.61(11)$ & $\begin{array}{l}\text { Ge }(L i), \\
\text { Noncoincidence }\end{array}$ \\
\hline
\end{tabular}

(a) Data normalized to prominent photopeak in normal Ge (Li) spectra. The prominent gamma rays are underlined.

(b) (1) 2 to 5 days decay; (2) 7 to 11 days decay; (3) 20 to 30 days decay.

(c) The values in parentheses are peak to compton ratios in a given decay interval. 
Three different counting systems and three radioactive decay periods were evaluated for quantifying the series of rare earth elements in biological samples. The counting system included: 1) a normal $\mathrm{Ge}(\mathrm{Li})$ detector $(130 \mathrm{~cm}$, $26 \%$ efficiency, full width at half maximum of $1.8 \mathrm{KeV}$ for $1332 \mathrm{Kev} r$ of $60 \mathrm{Co}$ ) at $0.50 \mathrm{KeV} /$ channel; 2) a $19 \mathrm{~cm}^{2}$ surface area low-energy photon detector (planar, intrinsic Ge; full width at half maximum of $0.71 \mathrm{KeV}$ for $122 \mathrm{KeV}$ $r$ of $\left.{ }^{58} \mathrm{Co}\right)$ at $0.2 \mathrm{KeV} / \mathrm{channel}$ for $x$-ray and low-energy (<400 KeV) r-rays; and 3 ) a coincidence-noncoincidence $\mathrm{Ge}(\mathrm{Li})-\mathrm{NaI}(\mathrm{Tl})$ detector system (130 cc, $26 \%$ efficiency, full width at half maximum of $1.9 \mathrm{KeV}$ for $1332 \mathrm{KeV} \mathrm{r}$ of ${ }^{60} \mathrm{Co}$ ) at $0.5 \mathrm{KeV} / \mathrm{channel}$. For biological materials, detection of the trace rare earth element concentrations was enhanced with the low-energy photon and the coincidence-noncoincidence detectors. To compare the relative detection sensitivities of the individual rare earth elements by these three systems, we have calculated ratios of specific activities of the various rare earth isotopes in a rare earth standard that was counted on each of the counting systems. These data are presented in Table 1 . The most favorable mode for detection of an individual rare earth can be determined by comparing the numerical values of these relative intensity ratios.

Based on the comparison shown in Table 1 , normal $\mathrm{Ge}(\mathrm{Li})$ counting is favored for $140 \mathrm{La}$ and $160 \mathrm{~Tb}$; noncoincidence counting for $141_{\mathrm{Ce}}$, $143 \mathrm{Ce}, 142 \mathrm{Pr}$, $153 \mathrm{Sm}(103 \mathrm{KeV}) 171 \mathrm{Er}$, and $175 \mathrm{Yb}$; and low-energy photon detection counting for $147 \mathrm{Nd}, 153 \mathrm{Sm}(41 \mathrm{keV}), 166 \mathrm{Ho}$, and 169 YB. The detection of $152 \mathrm{mEu}, 159 \mathrm{Gd}$ ( 363 $\mathrm{KeV})$, and $177_{\mathrm{Lu}}$ is equally sensitive by normal $\mathrm{Ge}(\mathrm{Li})$ and non-coinc idence counting; $152 \mathrm{Eu}$ (122 KeV) detection is equally sensitive by both low energy photon detection and normal $\mathrm{Ge}(\mathrm{Li})$; and $153 \mathrm{Gd}(98 \mathrm{KeV})$ and $170 \mathrm{Tm}$ are equally sensitive by all counting modes. Since neodymium is the principle analog for americium and curium, low energy photon detection is the preferred counting mode. For those samples where the concentrations of the whole series of rare earths are desired, the samples are also counted on the coincidence-noncoincidence counting system. This approach provides optimum analytical sensitivity for nearly the entire series of rare earth elements. 


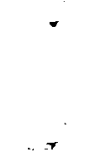




\title{
- Long-Term Plant Availability of Actinides
}

\author{
Principal Investigators: R. G. Schreckhise and J. F. Cline
}

Environmental releases of actinide elements raise issues about which data are very limited. Quantitative information is required to assess the long-term behavior of actinides and their potential hazards resulting from the transport through food chains leading to man. Of special interest is the effect of time (weathering, aging and associated biological processes in soil) on the changes in the availability of actinide elements for uptake by plants from soil. This study provides valuable information on the effects of weathering and aging on the uptake of actinides from soil by range and crop plants grown under realistic field conditions.

ROUT INE MAINTENANCE

Work on this project during this past year primarily involved the care and maintenance of plants grown in field lysimeters. Plants are harvested at maturity and either submitted for radiochemical analys is or archived for future reference purposes. The 1981 harvest represented the sixth year of harvest for the 20-cm subsurface layer lysimeters and the eight year for the thin subsurface layer lysimeters. Selected samples from the 1979, 1980 and 1981 activities have been submitted for radiochemical analyses. Completion of these analyses will provide data through a six- or 8-week period and will facilitate a rigorous statistical evaluation of changes in plant availability.

\section{DATA MANAGEMENT SYSTEM}

A data-management system has been developed for use on this project. An existing system, presently in use at PNL, was modified to handle the large amount of data that is produced in this study. The system will enhance the statistical evaluation of the data by allowing more in-depth analyses. It also should reduce errors, since most of the data will eventually be collected and directly entered into the system with the use of a remote computer terminal located at the Arid Lands Ecology (ALE) facilities. 


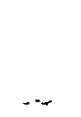




\title{
- Radioecology of Nuclear Fuel Cycles
}

\author{
Principal Investigator: L. L. Cadwell
}

Associate Investigators: L. E. Eberhardt, R. M. Emery, J. F. Cline, K. A. Gano, W. T. Hinds, T. M. Poston, L. E. Rogers and R. G. Schreckhise

Radioecology of nuclear wastes was pioneered in the western United States on the Hanford site during the early 1940 s when the Columbia River provided coolant water for production reactors. After the shutdown of production reactors, the radionuclide content of Columbia River water declined. Attention was then directed to radionuclides released into the environment as a result of chemical processing of irradiated fuel and as a result of storage of radioactive wastes. Radioactive waste sites include solid waste burial grounds, soils below liquid storage areas, surface ditches and ponds, and the terrestrial environment around chemical processing facilities which discharge airborne radioactive debris from stacks.

This study provides information to help assess the environmental impacts and certain potential human hazards associated with nuclear fuel cycles. A data base is being developed to define and quantify biological transport routes, which will permit credible predictions and assessment of routine and potential large-scale releases of radionuclides and other toxic materials. These data, used in assessment models, will increase the accuracy of estimating radiation doses to man and other life forms. Information obtained from existing storage and disposal sites will provide a meaningful radioecological perspective with which to improve the effectiveness of waste management practices. Results will provide information to determine if waste management procedures on the Hanford site have caused ecological perturbations, and, if so, to determine the source, nature and magnitude of such disturbances.

\section{BIOTIC TRANSPORT PARAMETERS}

Studies related to biotic transport are being conducted to provide meaningful parameters for dose assessment. The studies include def ining how parameters are influenced by environmental variables and determining the magnitude of transport parameters that are not well known.

Soil Contamination Configuration. Laboratory studies were conducted to examine the influence of radionuclide placement (location relative to the plant root zone) on the concentration of strontium and cesium in crop plants. The data indicate that uptake may be slightly enhanced in peas when the radionuclide is at or near the soil surface (Table 1). Plant uptake of radionuclides distributed in a thin band below the soil surface (as might occur if a contaminated pond were drained and then covered with soil) was similar to uptake of radioactive material mixed throughout the effective rooting medium (as might occur with standard agricultural tillage operations subsequent to a soil surface deposition of radioactive materials). Care was taken in this experiment to minimize resuspension of surface contaminants while approximating a fieldgrowing condition. The implication of these findings is that dose assessment calculations using concentration ratios $(C R=$ radionuclide concentration in plant tissue divided by the radionuclide concentration in soil) can be used without alteration for waste disposal scenarios, where the radioactive material is layered beneath the soil surface, and for agricultural scenarios, where the contaminants have been mixed in the upper soil layer by tillage operations. A further implication, however, is that application of the CR for dose assessment requires that empirically derived CR values be obtained by sampling a core through the effective rooting zone of the plant or that allowances be made for any surface layering of radiocontaminants if only surface soil is sampled. The application of $C R$ values to dose assessment have little "real world" relevance when contaminants are thinly layered on the soil surface, since the processes that then determine plant concentrations can be predominantly physical rather than biological.

Food Chain Transfer of Technetium. In a colTaborative research effort (see "Environmental Behavior and Effects of Technetium-99 and Iodine-129"), we examined the transport of technetium from feed to edible portions of Japanese quail (Cotournix cotournix japonica). 
TABLE 1. Concentrations $(\mu \mathrm{Ci} / \mathrm{g})$ of $\mathrm{Cs}$ and $\mathrm{Sr}$ by Peas Relative to Location of the Radionuclides in the Soil Profile

\begin{tabular}{|c|c|c|c|c|c|c|}
\hline \multirow{2}{*}{$\begin{array}{l}\text { Sirontium-85 } \\
\text { Harvest \#1 }\end{array}$} & \multicolumn{6}{|c|}{ Placement of Radionuclide in the Soil Profile } \\
\hline & $\begin{array}{l}\text { In Surface } \\
100 \text { gram }\end{array}$ & $\begin{array}{l}\text { In Layer } 5 \mathrm{~cm} \\
\text { Below Surface }\end{array}$ & $\begin{array}{l}\text { In Layer } 10 \mathrm{~cm} \\
\text { Below Surface }\end{array}$ & $\begin{array}{l}\text { In Layer } 40 \mathrm{~cm} \\
\text { Below Surface }\end{array}$ & $\begin{array}{l}\text { In Surface Layer } \\
(0-20 \mathrm{~cm}) 3.5 \mathrm{Kg}\end{array}$ & $\begin{array}{l}\text { In all Profile } \\
(0-50 \mathrm{~cm}) 8.9 \mathrm{Kg}\end{array}$ \\
\hline $\begin{array}{l}\text { Strontium-85 } \\
\text { Harvest } \# 1 \\
\text { Seeds } \\
\text { Leaves } \\
\text { Stems and } \\
\text { Pods }\end{array}$ & $\begin{array}{l}(4.5 \pm 0.6) \cdot 10^{-5}(a) \\
(3.3 \pm 0.4) \cdot 10^{-3}(a) \\
(1.1 \pm 0.2) \cdot 10^{-3}(a, b)\end{array}$ & $\begin{array}{l}(2.8 \pm 0.2) \cdot 10^{-5}(b) \\
(3.3 \pm 0.3) \cdot 10^{-3}(a) \\
(9.3 \pm 1.1) \cdot 10^{-4}(b, c)\end{array}$ & $\begin{array}{l}(5.6 \pm 1.4) \cdot 10^{-5}(a) \\
(4.5 \pm 0.7) \cdot 10^{-3(a)} \\
(1.7 \pm 0.4) \cdot 10^{-3}(a)\end{array}$ & $\begin{array}{l}(2.0 \pm 0.7) \cdot 10^{-5}(b) \\
(1.4 \pm 0.5) \cdot 10^{-3(b)} \\
(4.9 \pm 1.1) \cdot 10^{-4}(c)\end{array}$ & $\begin{array}{l}(4.1 \pm 0.3) \cdot 10^{-5}(a, b) \\
(3.1 \pm 0.4) \cdot 10^{-3}(a) \\
(1.2 \pm 0.2) \cdot 10^{-3}(a, b)\end{array}$ & $\begin{array}{l}(2.4 \pm 0.3) \cdot 10^{-5}(\mathrm{~b}) \\
(1.8 \pm 0.4) \cdot 10^{-3}(\mathrm{~b}) \\
(7.5 \pm 1.3) \cdot 10^{-4}(\mathrm{~b}, \mathrm{c})\end{array}$ \\
\hline $\begin{array}{l}\text { Harvest } \# 2 \\
\text { Seeds } \\
\text { Leaves and } \\
\text { Stems }\end{array}$ & $\begin{array}{l}(2.4 \pm 0.7) \cdot 10^{-4}(a) \\
(5.9 \pm 0.9) \cdot 10^{-3}(a)\end{array}$ & $\begin{array}{l}(4.8 \pm 0.8) \cdot 10^{-5}(b) \\
(2.6 \pm 0.4) \cdot 10^{-3}(b)\end{array}$ & $\begin{array}{l}(5.0 \pm 1.6) \cdot 10^{-5}(b) \\
(1.8 \pm 0.3) \cdot 10^{-3}(b)\end{array}$ & $\begin{array}{l}(2.0 \pm 0.4) \cdot 10^{-5(b)} \\
\left(1.0 \pm 0.2 \cdot 10^{-3(b)}\right.\end{array}$ & $\begin{array}{l}(3.2 \pm 0.9) \cdot 10^{-s}(\mathrm{~b}) \\
(2.2 \pm 0.2) \cdot 10^{-3}(\mathrm{~b})\end{array}$ & $\begin{array}{l}(2.8 \pm 0.3) \cdot 10^{-5}(\mathrm{~b}) \\
(1.2 \pm 0.2) \cdot 10^{-3}(\mathrm{~b})\end{array}$ \\
\hline $\begin{array}{l}\text { Cesium-137 } \\
\text { Harvest } \# 1 \\
\text { Seed } \\
\text { Leaves } \\
\text { Stems and } \\
\text { Pods }\end{array}$ & $\begin{array}{l}(7.5 \pm 0.4) \cdot 10^{-4}(a) \\
(2.9 \pm 0.5) \cdot 10^{-3}(a) \\
(9.9 \pm 1.2) \cdot 10^{-4(a)}\end{array}$ & $\begin{array}{l}(1.0 \pm 0.1) \cdot 10^{-3}(a) \\
(4.8 \pm 1.5) \cdot 10^{-3}(a, b) \\
(1.9 \pm 0.4) \cdot 10^{-3}(b)\end{array}$ & $\begin{array}{l}(4.6 \pm 0.7) \cdot 10^{-4}(b) \\
(2.1 \pm 0.4) \cdot 10^{-3}(b) \\
(9.2 \pm 1.8) \cdot 10^{-4}(a)\end{array}$ & $\begin{array}{l}(6.2 \pm 2.8) \cdot 10^{-4}(a, b) \\
(1.4 \pm 0.6) \cdot 10^{-3}(b) \\
(6.5 \pm 2.0) \cdot 10^{-4}(a)\end{array}$ & $\begin{array}{l}(4.2 \pm 0.7) \cdot 10^{-4}(b) \\
(1.4 \pm 0.2) \cdot 10^{-3}(b) \\
(7.1 \pm 1.3) \cdot 10^{-4}(a)\end{array}$ & $\begin{array}{l}(2.6 \pm 0.2) \cdot 10^{-4}(b) \\
(6.3 \pm 0.3) \cdot 10^{-4}(b) \\
(3.7 \pm 0.5) \cdot 10^{-4}(a)\end{array}$ \\
\hline $\begin{array}{l}\text { Harvest } \# 2 \\
\text { Seeds } \\
\text { Leaves and }\end{array}$ & $\begin{array}{l}(2.5 \pm 0.6) \cdot 10^{-2(a)} \\
(4.0 \pm 1.0) \cdot 10^{-2}(a)\end{array}$ & $\begin{array}{l}(1.7 \pm 0.9) \cdot 10^{-3}(b) \\
(2.2 \pm 0.4) \cdot 10^{-3}(b)\end{array}$ & $\begin{array}{l}(4.6 \pm 1.0) \cdot 10^{-4}(\mathrm{~b}) \\
(9.0 \pm 0.6) \cdot 10^{-4}(\mathrm{~b})\end{array}$ & $\begin{array}{l}(5.6 \pm 1.2) \cdot 10^{-4}(b) \\
(8.0 \pm 2.3) \cdot 10^{-4}(b)\end{array}$ & $\begin{array}{l}(2.6 \pm 0.9) \cdot 10^{-3}(b) \\
(4.1 \pm 0.6) \cdot 10^{-3}(b)\end{array}$ & $\begin{array}{l}(1.5 \pm 0.8) \cdot 10^{-3}(b) \\
(1.6 \pm 0.8) \cdot 10^{-3}(b)\end{array}$ \\
\hline
\end{tabular}

$(a, b, c)$ Numbers reading across the page having the same subscript are not significantly different at $5 \%$ level using Duncan multiple range test.

Our results are contradictory to the frequently made food chain assumption that commercially raised fowl transfer a negligible (zero) percentage of ingested technetium. We found that the cumulative percentage of ingested technetium occurring in all eggs laid subsequent to a single acute ingestion was approximately $8 \%$.

Half-times for reduction of technetium in consecutively laid eggs subsequent to an acute ingestion were determined to be on the order of one to two days. A chronic ingestion study (ingestion measured at apparent technetium equilibrium in eggs) showed that approximately 85 of the daily ingested technetium was incorporated into and eliminated via the egg. Virtually all of the technetium contained in the eggs was associated with the edible portions (yolk and arbumin). Percent of daily ingested technetium in edible tissues (muscle, heart, liver and gizzard) of the birds after about two weeks of chronic ingestion was $1.7 \%$ for females and $7.3 \%$ for males. The cumulative percentage of the daily ingested technetium associated with the female reproductive system (uterus, ovary, oviduct, shelled egg and ova of various sizes) was approximately $23 \%$. Male reproductive organs contained less than $1 \%$ of the technetium ingested daily. Thus, it appears that a large diversion of technetium to eggs in laying female quail may minimize the amount going to edible tissues in the birds.

Japanese quail are considerably smaller than chickens and have some fundamental functional differences. Their metabolism is higher than that of chickens, and their unit egg production, as a percent of total body weight, is about twice that of chickens. These differences notwithstanding, our data suggest that transfer coefficients (feed to egg) for technetium in chickens may be in the range of $1 \%$ to $10 \%$. Considering the long physical halflife of $99 \mathrm{Tc}$ and the potential for release to the environment with nuc lear fuel reprocessing, these results suggest a food chain pathway to man of long-term significance.

Aquatic Concentration Ratio Evaluation. A comprehensive review was initiated in order to better define the wide range of reported concentration ratios used for dose assessment of radionuclide contamination in aquatic systems. Approximately 800 publications have been reviewed thus far. The publications fall into four broad categories: 1) laboratory or artificial pond studies; 2) chronic low-level or acute discharges to the environment; 
3) background and fall-out levels of radionuclides; and 4) homologues, including elemental or specific activity concentrations. Particular attention is being focused on natural and laboratory environmental conditions that influence observed concentration ratios. Compilation and analysis of data will provide user groups with a basis for selecting the most appropriate model parameter values for their individual dose assessment needs. 0ther applications of the biotic transport parameter review include model evaluation and identification of transport processes that have unknown or poorly defined parameter values.

\section{AQUATIC RADIOECOLOGY}

Recent emphasis in aquatic studies has been on the uptake and toxicity of uranium and thorium. This work was initiated as a result of recent emphasis on nonproliferative fuel cycles and the projected increased potential for uranium and thorium contamination of aquatic systems.

Fate and Effects of Th and $U$. The proposed use of thorium and uranium fuels as an alternative, nonproliferation fuel cycle has prompted study of the environmental behavior of thorium and uranium in aquatic environments. The propensity of thorium to accumulate in $\mathrm{f}$ ish tissue was determined to be very low. Body burdens of thorium were highest during the exposure periods due to gut loading and/or surface absorption of contaminated particulates. At 5 and 25 days depuration, body burdens had dropped to less than $5 \%$ of the highest observed body burdens of thorium. Concentration ratios (concentration in $f$ ish divided by concentration in water) reflected this trend. After 27 days of exposure to thorium, mean concentration ratios (CR) ranged between 58 and 465 . At 5 days depuration, the CRs were 0.7 and 8.1 , respectively. The persistance of the same levels of thorium at 25 days depuration suggests that the observed body burden levels represent tissue-bound thorium.

Concentration ratios for uranium were also low: 2.0 to 2.8 following 35 days of exposure. Uptake of thorium and uranium was similar for fish exposed to approximately the same concentration of thorium and uranium. This observation contradicts suggested CRs for thorium and uranium based on background levels in water and $\mathrm{f}$ ish tissue. The background-based CRs should range up to $2.2 \times 10^{4}$ and $\sim 2 \times 10^{2}$ for uranium.

Toxicity of Uranium in Columbia River Water. The acute toxicity of uranium for Daphnia magna was determined as a function of water hardness. Toxicity of Uranyl ion $\left(\mathrm{UO}_{2}{ }^{+6}\right)$, which forms carbonate complexes at neutral to alkaline $\mathrm{pH}$, is reduced as water hardness increases. The hardness of water tested was $70.1 \pm 1.6,134.4 \pm 4.4$, and $195.4 \pm 4.0 \mathrm{mg} / \mathrm{L}$ $\mathrm{CaCO}_{3}$ equivalents. Based on the combined data of replicate tests, the toxicological response (48-hour $L C_{50}$ ) of 0 . magna to uranium as a function of water hardness may be predicted by the function $L C_{50}=39.32$ in (water hardness), which is 159.7 within the range of 70 to $200 \mathrm{mg} / \mathrm{L}$ total hardness (Figure 1 ).

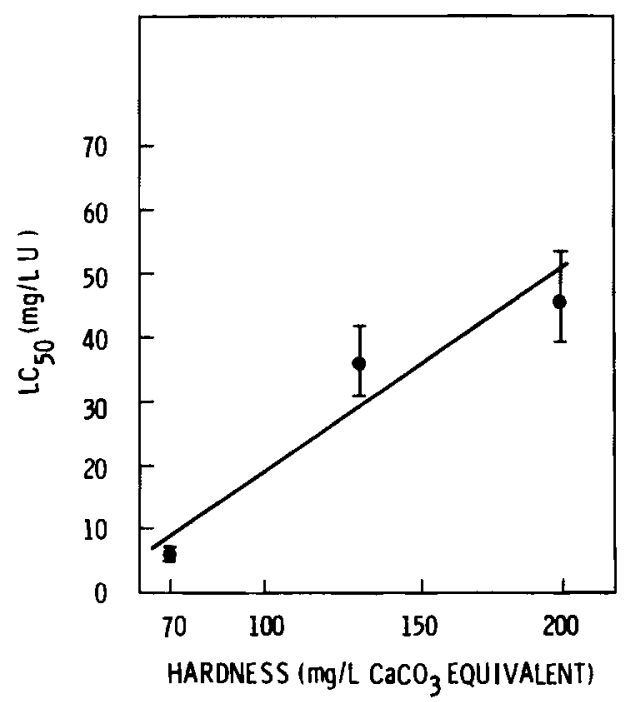

FIGURE 1. Acute Toxicity of Uranium on Daphnia magna as a Function of Water Hardness

The $L_{50}$ in Columbia River ranged from 5.34 to $7.62 \mathrm{mg} / \mathrm{L}$ uranium. Twenty-one-day replishment life cycle tests with Columbia River water suggested that reproduction was suppressed at concentrations as low as $0.57 \mathrm{mg} / \mathrm{L}$ uranium.

There was evidence of stimulation of reproduction to levels exceeding the control response in the range of 0.20 to $0.74 \mathrm{mg} / \mathrm{L}$. The effect may be a result of interactions between uranium toxicity, loading density of adult daphnids in the test chambers, and food supply.

Reported concentrations of uranium in groundwater in the vicinity of uranium mines of ten exceeds the toxic concentrations demonstrated in these studies. The fact that the hardness of this groundwater is usually high may be self mitigating; however, the toxic hazards of uranium in soft water is of concern. 


\section{TERRESTRIAL RADIOECOLOGY}

These studies consist primarily of field work on environmental radiocontaminants that result from nuclear waste management and waste disposal activities. The research is designed to ident ify processes and develop methods that can be used to evaluate and ultimately reduce risks associated with nuclear waste management processes.

Fire and Wind Erosion. Creating and maintaining a stable vegetative cover over waste burial sites often requires manipulating or controlling various aspects of the life cycle of the vegetation. This is particularly true for stabilizing the surface after a significant disturbance such as fire and/or wind erosion. Two aspects of response to disturbance were investigated this year: loss of seeds due to wind erosion, and long-term behavior of litter layers in stable cheatgrass swards that serve as models for waste burial site vegetation.

Seed loss is a significant hinderance to revegetation following fire. To estimate the importance of seed loss, the top $3 \mathrm{~cm}$ of soil in an eroded area in a small scar from a 1979 fire was sampled for seeds. A nearby unburned area was similarly sampled. The results suggest that a total of some 5,000 seeds $/ \mathrm{m}^{2}$ resided in the undisturbed soil. After fire, and a subsequent wind erosion loss of about $1 \mathrm{~cm}$ of soil, the number of seeds available for sprouting was reduced by $50 \%$, to about 2,000 seeds $/ \mathrm{m}^{2}$. The importance of the surface layer is clear: in both cases, more than $90 \%$ of the seeds were in the top centimeter. Apparently, the soil disturbance associated with erosion allows seeds to trickle deeper in the soil, so that not all seeds in the top centimeter are lost with the top centimeter of soil. This observation coincides with earlier experience that about 3 to $5 \mathrm{~cm}$ of soil must be lost before the entire seed stock is lost, even though the seeds originally were only in the top centimeter.

Radiocesium in Deer. A standard method for evaluating radionuclide concentrations in deer near radioactive waste management areas is to collect samples from deer killed on roads. However, data collected in this manner are difficult to interpret since no information is available on the past histories and potential exposures of individual animals to radioactive contaminants. In this study, deer are being captured in the vicinity of Hanford waste management ponds, equipped with radiocollars, and released. Deer are then relocated at random times (three days to a week) to estimate the proportion of time spent near waste management sites. Individuals are sacrificed and samples including muscle, gut, and liver are analyzed for gamma-emitting radionuclides. Additional deer are being radiocollared throughout the Hanford site to monitor general movement patterns.

Twenty-seven deer have been captured and radiocollared on the Hanford site; nine of these animals were marked in the vicinity of the 200-Area waste management ponds. Three of the 200-Area deer were collected for sample analysis. The remaining six deer either moved away from the 200 Area prior to the threemonth residency required for ${ }^{137} \mathrm{Cs}$ to reach equilibrium or had radiocollars which malfunctioned. The ${ }^{137} \mathrm{Cs}$ values for muscle tissue from the three sacrificed deer ranged from 0.51 to $1.02 \mathrm{pCi} / \mathrm{gm}$ wet weight. The three sacrificed individuals spent from $52 \%$ to $100 \%$ of their time within $2 \mathrm{~km}$ of the waste management ponds.

Following completion of the field tracking, ${ }^{137} C_{s}$ values for these animals with known past histories will be compared to data from road-killed deer. Comparable data exists for five deer killed between 1971 and 1979 on roads near the 200 Area and for 23 roadkilled deer found elsewhere on the Hanford site.

Portions of this study are being supported by funds received from DOE-RL.

Waterfowl Movement Studies. Twenty mallard ducks were trapped at Gable Mountain Pond and fitted with radio-transmitters and U.S. Fish and Wildlife Service leg bands. Five of the mallards were fitted with radiotransmitters just prior to the start of the waterfowl hunting season. Thereafter, at approximately one month intervals, three additional sets of five mallards were fitted with radio-transmitters. An additional 157 mallards were leg banded. Radio frequencies from each duck were monitored continuously by receiver/recorder stations located at both Gable Mountain Pond and B-Pond. Supplementing the recorder stations, periodic monitoring of radio-tagged ducks were checked at Gable Mountain Pond, B-pond, Wet Lake, B-2-3 Chem Waste Ditch (inside $300 \mathrm{E}$ ), and the Hanford Reach of the Columbia River.

The four cohorts of radio-transmitterized mallards captured at consecutive one-month intervals had average residence times on the waste ponds of $71,41,13$ and 2 days, respectively. Over the same time interval, the total number of mallards in the vicinity of the waste ponds was changing rapidly as a result of migratory movements.

Six mallards (including 2 of the radio-tagged mallards) were sampled selectively from Hanford waste ponds, and two additional control 
mallards were shot 5 miles west of West Richland. Muscle samples were analyzed for $137 \mathrm{Cs}$. Mallard muscle collected at Hanford ponds contained an average of $101.43 \pm 41.41 \mathrm{pCi}$ $137 \mathrm{Cs} / \mathrm{gm}$ dry weight. Cesium-137 in control mallards averaged $0.02 \pm 0.01 \mathrm{pCi} / \mathrm{gm} \mathrm{dry}$ weight.

These data suggest that routine collection and radionuclide analys is of waterfowl tissues used for dose estimation should be closely correlated with the hunting seasons. Sampling the waste ponds early in the hunting season will provide a high proportion of birds having maximal radionuclide concentrations. Later sampling should show dramatically reduced radionuclide concentrations and a much lower frequency of "above background" birds. The dose-to-man implications from changing numbers of waterfowl on the ponds during the hunting season and the differential radionuclide concentrations in their tissues suggest the potential for a few individuals to consume birds having maximal radionuclide concentrations versus a chance that more people (hunters and their families) could consume flesh having lower concentrations of radionuclides.

Honeybee Study. This work is intended to document the reliability of honeybee colonies as monitors of radionuclide contamination, to determine the occurrence and survival of wild honeybee colonies within the semi-arid Hanford environment, and to evaluate their potential for transporting waste materials away from managed sites via honey and pollen.

Honey and pollen samples were collected during 1980 from colonies established near and remote from radioactive waste facilites. Results of the pollen analysis are shown in Table 2 . Elevated quantities of $60 \mathrm{Co}, 134 \mathrm{Cs}, 137 \mathrm{Cs}$ and
$54 \mathrm{Mn}$ were noted for colonies loc ated near 100-N facilities. Counts associated with 137 Cs also appeared higher for colonies located near Gable Pond. Analysis of the honey samples has not been completed. A total of 16 wild honeybee colony locations have been located on Hanford. Two were removed or killed due to their close proximity to work areas. More than $50 \%$ of the remaining colonies have survived over at least one winter, indicating that feral honeybees $c$ an be expected to inhabit most of the Hanford area.

Plant and Animal Responses to Buried Wastes. Two new subtasks were initiated this fiscal year on the radioecological aspects of shallowland burial of low-level wastes. One study involves methodology development for examining the functional rooting depth of plants growing over buried waste. In some situations, plant covers are desirable because they provide economical stabilization of the soil surface and extract soil moisture which otherwise could penetrate through the wastes and leach contaminants to groundwater. Deeply rooted plants, however, may extract and return radiocontaminants to the soil surface.

The second study involves an examination of burrowing small-mammal population densities that occur in response to the vegetation types established for waste burial ground stabilization. Animal penetrations through the soil covering may expose radionuclides for mobilization and distribution in the environment. With these two studies, we plan to provide information on interactions and relationships between buried wastes and the nearby plant and animal populations in order to permit more ef fective isolation of buried low-level wastes from the environment.

TABLE 2. Radioactive Contaminants of Pollen Collected from Honeybee Colonies

\begin{tabular}{|c|c|c|c|c|c|}
\hline Contaminant & B-Pond & Gable Pond & $100 \mathrm{~N}$ & U Pond & $\begin{array}{c}\text { Snively } \\
\text { (control) }\end{array}$ \\
\hline${ }^{60} \mathrm{Co}$ & $0.015-0.024$ & $0.022-0.035$ & $0.87-6.15$ & $0.027-0.036$ & $0.014-0.025$ \\
\hline${ }^{134} \mathrm{Cs}$ & $<0.014-<0.025$ & $<0.020-0.040$ & $2.67-2.82$ & $<0.022-0.029$ & $0.044-0.063$ \\
\hline${ }^{137} \mathrm{Cs}$ & $0.144-0.483$ & $1.27-3.95$ & $7.66-59.3$ & $0.138-0.639$ & $0.074-0.081$ \\
\hline${ }^{40} \mathrm{~K}$ & $13.5-16.5$ & $10.6-11.7$ & $12.9-15.1$ & $10.1-10.5$ & $15.4-21.2$ \\
\hline${ }^{54} \mathrm{Mn}$ & $<0.011-0.031$ & $<0.16-0.022$ & $3.52-30.8$ & $0.019-0.020$ & $0.012-0.077$ \\
\hline
\end{tabular}





\title{
- Environmental Behavior of Technetium-99 and lodine-129
}

\author{
Principal Investigators: T. R. Garland and R. G. Schreckhise
}

Associate Investigators: R. E. Wildung, D. A. Cataldo, K. M. McFadden, L. C. Neil, J. Rogers, S. W. Li, J. M. Thomas and L. L. Caldwell

The environmental behavior of technetium-99 and iodine-129 was once thought to be similar, particularly with respect to their soil solubility and biological interactions. Over the past several years, we have attempted to study the comparative behavior of these two anions with respect to their fate in natural environments (both aquatic and terrestrial) and to determine the specific mechanisms that account for observed differences in their behavior. The mechanisms studied include physical, chemical and biological parameters that account for differences in soil behavior, cycling between soil and/or air to vegetation, adsorption and metabolism in plants, and their availability and fate following ingestion by animals.

CYCLING OF ${ }^{99}$ TC AND ${ }^{129} \mathrm{I}$ WITHIN THE BOUNDARIES OF A HANFORD FUELS REPROCESSING FACILITY

Continuing studies at two fuel reprocessing sites within the boundaries of the 200-W Area provide a unique opportunity to evaluate the comparative behavior of gaseous releases and liquid effluents in an arid environment. As noted in previous annual reports, concentration ratio (CR) values at these sites range from 0.01 to 14 for $137 \mathrm{Cs}, 0.6$ to 5.0 for $129 \mathrm{I}, 0.1$ to 1.0 for $127 \mathrm{I}$ (stable endogenous iodine), and 4 to 460 for $99 \mathrm{TC}$. While values for $129 \mathrm{I}, 127 \mathrm{I}$ and $137 \mathrm{Cs}$ are not particularly out of range for risk assessment calculation, the unusually high CR values attained for ${ }^{99}$ Tc (as noted in early laboratory studies) represent a potential problem due to cycling and recycling between soils, plants and litter. Considering the general behavior of radionuclides, these high CR values need to be investigated, particularly in the area of soil behavior/cycling and plant/animal transfer.

\section{BIOLOGICAL BEHAVIOR OF TECHNETIUM}

\section{Microorganisms}

The fungus Trichoderma-380, which was isolated from soil, has been examined for its ability to transport the $\mathrm{TCO}_{4}^{-}$form. Little is known of the role microorganisms may play in modifying the chemical form of technetium in the environment. Plant uptake studies have indicated that technetium may be acting as a sulfur analog in plants. Since plants and most microorganisms show a common mechanism for the uptake and metabolism of sulfur, our initial studies have concerned the transport of $\mathrm{TCO}_{4}{ }^{-}$by Trichoderma-380 induced for the transport of sulfate. Pertechnitate
$\left(\mathrm{TCO}_{4}{ }^{-}\right)$transport was enhanced 21 -fold when late $\log$ cultures were further incubated for 20 to 22 hours in sulfur-free media, a process known to induce a specific sulfate transport system. In a similar study, sulfate transport was enhanced 1100-fold. However, unexpectedly sulfate at $0.1,1$ and $10 \mathrm{~m} \mathrm{M}$ did not inhibit $\mathrm{TCO}_{4}^{-}(42.5 \mu \mathrm{M})$ transport by sulfur-starved cultures. No inhibition was observed with the anions, $\mathrm{PO}_{4}, \mathrm{MoO}_{4}{ }^{-}, \mathrm{Cl}^{-}$or $\mathrm{NO}_{3}{ }^{-}$. $\mathrm{TCO}_{4}{ }^{-}$transport followed saturation kinetics with a $\mathrm{Km}$ of $50 \mu \mathrm{M}$ and was $\mathrm{pH}$-dependent with maximal observed activity of $\mathrm{pH} 3.0$. Inconsistant results were found with inhibitors of active transport systems. Inhibition was observed with 2,4-dinitrophenol, whereas azide enhanced $\mathrm{TCO}_{4}{ }^{-}$uptake approximately 2fold. The exact mechanism of azide enhancement is not known, but azide did not alter the chemical form. $\mathrm{TCO}_{4}^{-}$and $\mathrm{SO}_{4}^{-}$do not appear to share the same transport mechanisms with Trichoderma-380, although methods that induce $\mathrm{SO}_{4}{ }^{-}$transport also induce $\mathrm{TCO}_{4}{ }^{-}$ transport.

Plants. Previous studies have shown that technetium is readily accumulated by soybean seedlings placed in hydroponic solutions containing technetium levels comparable to environmental concentrations $(0.02 \mathrm{pg} / \mathrm{ml})$. Root adsorption $c$ an be shown to meet prerequisites for active, metabolic absorption over a broad range of concentration ( 1 to $1000 \mathrm{pg} \mathrm{Tc} / \mathrm{ml}$ ). It is this ease of biological accumulation from both soils and solutions that is responsible for the unusually high $C R$ values reported for technetium. Kinetic analysis of the absorption process in the presence and absence of competing anions showed $\mathrm{TCO}_{4}^{-}$uptake to share a common process with the nutrient ions $\mathrm{SO}_{4}{ }^{2-}, \mathrm{H}_{2} \mathrm{PO}_{4}^{-}, \mathrm{SeO}_{4}{ }^{-}$and $\mathrm{MoO}_{4}{ }^{2-}$. The analog behavior of nonnutrient elements to nutrient species is not unusual, and has been shown to be operational for cesium/potassium 
and strontium/calcium. What makes technetium unusual is the comparative rate of absorption and ease of metabolism.

Since previous studies have shown technetium to be chemically toxic to plants, a logical assumption based on analog studies was that technetium was substituting for an essential element in metabolic systems employing sulfur, phosphorous, or molybdenum, resulting in metabolic dysfunction. Based on transport behavior, remobilization patterns and preliminary enzyme studies, an S/TC interaction was indicated. Using ${ }^{3} \mathrm{SO}_{4}{ }^{2-}$ and ${ }^{99} \mathrm{TcO}_{4}{ }^{-}$, plants were pulsed, leaf and root tissues fractionated, and solubles subjected to various chemical and chromatographic separation schemes. A typical sephadex (G-50F) separation pattern obtained for ${ }^{99} \mathrm{Tc}$ and $35 \mathrm{~S}$ contained in solubles of leaves and roots is shown in Figure 1 . Distribution patterns for both elements are similar for roots and leaves. The majority of both ${ }^{99} \mathrm{Tc}$ and $35 \mathrm{~S}$ in roots is in the lower molecular weight region and contains $-60 \%$ inorganic $\mathrm{SO}_{4} 2^{-}$and $\mathrm{TCO}_{4}^{-}$, with the remainder
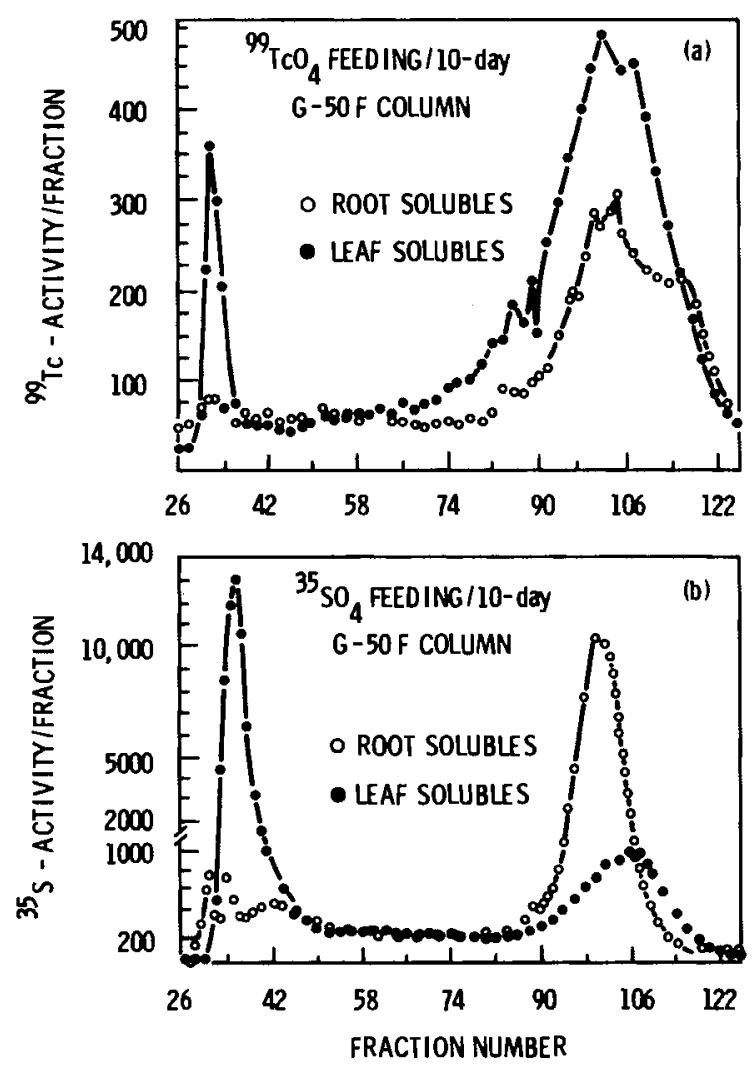

FIGURE 1. Comparative Behavior of ${ }^{99} \mathrm{TCO}_{4}^{-}$and ${ }^{35} \mathrm{SO}_{4}{ }^{2-}$ During Metabolism in Leaf and Root Tissues of 28-DayOld Soybean Plants persisting as complexed $S$ and Tc. The higher molecular weight components eluted near the exclusion volume of column were found only in the leaves, suggesting a synthesis of proteins. These high molecular weight components are currently under study.

The lower molecular weight components containing peptides, amino acids, and inorganic technetium and sulfur were further separated by cation-anion exchange resins to isolate the amino acid fraction. In both the $35 \mathrm{~S}$ and ${ }^{99} \mathrm{Tc}$ soluble fraction, $14 \%$ of the activity was recovered from the amino acid fraction. Amino acid separations using thinlayer electrophoresis (TLE) and thin-layer chromatography (TLC) were undertaken on low molecular weight components before and after cation exchange separation of the amino acid components. Methionine, cysteine, cystine, their oxidation products and $\mathrm{SO}_{4}{ }^{2-}$ were present in both $35 \mathrm{~S}$ fractions. Fractions containing technetium showed $\sim 40 \%$ of the components to be cationic (as with the sulfur amino acids) following TLE of the low molecular weight fraction. Analysis by TLE and TLC of the fraction containing amino acids (following cation exchange separation) showed the presence of one major cationic component, four minor cationic components, a major anionic component $\left(\mathrm{TCO}_{4}^{-}\right)$, and a large intermediate anionic component (incompletely oxidized technetium). The latter data from cation exchange separations and TLE suggest that the components (possibly amino acids) that contain technetium are unstable and may account for the observed phytotoxicity. Studies are currently continuing to resolve the metabolic behavior of technetium in plants, with particular emphasis on the adenosine $5^{\prime}$-phosphosulfate metabolism pathway.

AVAILABILITY OF PLANT-INCORPORATED ${ }^{99}$ TC AND ${ }^{99} \mathrm{TCO}_{4}^{-}$TO ANIMALS

Over the past several years, animal feeding studies have been underway to determine the influence of plant metabolism on radionuclide chemical form and subsequent gut absorption by animals: Studies with guinea pigs (herbivore) and rats (omnivore) fed inorganic ${ }^{99} \mathrm{TCO}_{4}{ }^{-}$or plant incorporated ${ }^{99} \mathrm{TC}$ showed GI absorption to be reduced by $\sim 50 \%$ when incorporated into plant tissues compared with inorganic ${ }^{99} \mathrm{TCO}_{4}{ }^{-}$. In light of recent plant studies suggesting that technetium and sulfur may be metabolic analogs, the ingestion route was reevaluated using chinese quail. It was assumed that the technetium/sulfur analog phenomena may be readily verified by evaluating the flow of technetium from feed to egg, which contains substantial sulfur. 
Transfer of Technetium to Eggs of Quail. Technet ium fed to female quail (Cotourinix japoniua) in feed containing technetium incorporated in plant tissue or as amended as inorganic technetium showed a significant fraction transferred to egg. Under acute feeding conditions, total technetium absorbed and transferred to eggs ranged from $7.39 \%$ to $8.81 \%$ of the ingested dose of feed amended with tracer $\left({ }^{9} \mathrm{TcO}_{4}{ }^{-}\right)$concentrations. Birds given technetium incorporated in alfalfa leaves showed less transfer to eggs. Peak incorporation occurred between 2 and 3 days post-oral administration with a biological $\mathrm{T}_{1 / 2}$ for eggs of $1.8 \pm 0.1$ day.

For female quail chronically fed technetium incorporated in feed, equilibrium was reached after 5 to 7 days of feeding. The percent of ingested dose per egg averaged $8.82+1.7$ for al1 eggs laid after 7 days. After $1 \frac{1}{3}$ to 14 days of ingestion, approximately $80 \%$ of the technetium in eggs was associated with yolk, $20 \%$ with albumin, and $21 \%$ with she 11 and associated membranes. 
. 


\section{Marine Research Program}





\section{MARINE RESEARCH PROGRAM}

\section{- Trace Metals Metabolism in Marine Animals}

- Bioavailability of Energy Effluent Materials in Coastal Ecosystems

- Marine Chemistry of Energy-Related Pollutants

- Coordination: Pacific Marine Science Program

In recent years, a growing realization about the limits of land-based food and energy resources has resulted in increased use of the ocean and coastal marine ecosystems for these purposes. New development and expansion of existing energy facilities now account for the major industrial use of marine environments. Aside from oil and gas, the ocean provides such new energy resources as ocean thermal energy conversion (OTEC), tidal power, wave power, and biomass; and it receives direct discharge of many waste products including heat, oil and gas well effluent, and low-level nuclear wastes. In addition, the ocean is the ultimate sink for many materials discharged to the land, atmosphere, and freshwater streams. Many transferable energy sources-oil, gas, liquefied gas, synfuels and other future energy sources-are transported either directly across or in proximity to oceans and coastal zones. Given these activities, energy technologies can have a major impact on the marine ecosystem and, in particular, on the shallow coastal zone. Because of these diverse effluent problems, several distinct research efforts are being pursued currently in this program.

The research projects discussed in this section are multidisciplinary investigations of how materials discharged by energy technologies interact with the marine ecosystem. The studies identify the quantities and forms of contaminants that enter the marine ecosystem, measure existing background concentrations, and determine how physical, chemical, and biological factors influence the biological availability of these materials and their effects on organisms, populations, and communities of organisms.

Significant advances were made in the program dealing with trace metals metabolism in marine animals. Now we better understand 1) the role of metallothionein-like proteins in the intracellular binding and storage of trace metals; 2) how marine animals adapt to metal exposure by increasing their tolerance to metal toxicity and by involving mechanisms to repair tissue; 3 ) the relationship of metallothionein-like proteins to these adaptive responses; and 4) how immunoassays are developed for metallothionein-like proteins. Moreover, the program identified a population of mussel, Mytilus edulis, that is enriched in potentially toxic metals such as mercury, copper, and zinc. 
The Bioavailability of Energy Effluent Materials in Coastal Ecosystems Program concluded its research on factors that influence the uptake rate and availability of metals to marine animals. Data on the effect of interstitial water, sulfide, sediment, and concentration on the uptake rates and bioavailability were obtained. These data were compared to the previously developed copper model. Studies were initiated on the role of the sea-surface microlayer processes and their effect on the bioavailability of energy-related materials to the marine ecosystem. These studies are looking at how the microlayer of flora and fauna living in the upper $50 \mu \mathrm{m}$ of the ocean controls the transport rates of anthropogenic metal and hydrocarbon substances to the water column.

The Marine Chemistry Program is studying the processes by which metals and organic combustion products are removed from estuarine/coastal waters. Specific tasks pursued during the past year include: a study of the solubility of ${ }^{7} \mathrm{Be}$ and other radionuclides and metals on air particulate matter in seawater; a study of how elements adsorb to estuarine suspended matter; a study of how the flux of airborne metals and polynuclear aromatic hydrocarbons deposited to coastal water compare with the fluxes deposited by rivers and sewage effluent; and development of new and improved analytical techniques for measuring ultra-low concentrations of elements and compounds in marine samples.

Marine Research Programs on petroleum contamination funded by EPA and NOAA, and other programs on the ecology of the Puget Sound Region will be found in:

Annual Report for 1981 on Interagency/Contract Research. Ecological Sciences Department. 


\title{
- Trace Metals Metabolism in Marine Animals
}

\author{
Principal Investigator: G. Roesijadi \\ Associate Investigators: J. E. Morris(a) and J. S. Young
}

This research program is concerned with the response of marine animals to elevated concentrations of trace metals, a class of potentially toxic elements, which are released by energy technologies. Special emphasis has been given to the study of the mechanisms for the storage and detoxification of trace metals and the capacity of marine animals to adapt to metal-enriched environments.

The results of the past year have 1) extended our understanding of the role of metallothionein-like proteins in the intracellular binding and storage of trace metals; 2) demonstrated that marine animals are capable of adapting to metal exposure by increasing their tolerance to metal toxicity and by invoking mechanisms for tissue repair; 3) demonstrated that the metal-binding activity of metallothioneinlike proteins is associated with these adaptive responses; 4) resulted in continued progress toward development of immunoassays for metallothionein-like proteins; and 5) identified a population of the mussel Mytilus edulis that is enriched in potentially toxic metals such as mercury, copper, and zinc.

LOW MOLECULAR WEIGHT, MERCURY-BINDING PROTEINS IN THE MARINE MUSSEL

We learned in earlier work that the gills of Mytilus edulis possess low molecular weight, mercury-binding proteins that are similar to metallothionein with respect to induction by mercury exposure and the binding of mercury. Studies to determine the behavior of these proteins during a long-term exposure to mercury were completed in FY 1981.

Mussels were exposed to $5 \mu \mathrm{g} / \mathrm{L}$ mercury as $\mathrm{HgCl}_{2}$ for 28 days. Gill mercury accumulation, mercury incorporation into the soluble fraction and low molecular weight, mercurybinding proteins were determined as a function of time. Short-term mercury uptake rates of excised gills were also determined for animals sampled at intervals during the exposure. Gill mercury accumulation occurred in three phases: an initial net uptake phase (from start of exposure up to day 4), an intermediate stable phase (days 4 to 15), and a final net uptake phase at the end of exposure (days 15 to 28). The stable phase was associated with the induction of the predominant mercury-binding proteins and mercury incorporation into the proteins. After day 15, the mercury-binding proteins were saturated and "spillover" of mercury into high molecular weight proteins had occurred. Spillover corresponded with saturation of the soluble fraction, increases of mercury on particulate fractions, and a loss of the ability of gills

(a) Biology Department. to maintain stable mercury concentrations. Mercury uptake rates of gills were not affected by the 28-day exposure of the whole organism.

The phenomenon of spillover of certain toxic metals (e.g., cadmium, zinc, copper, mercury) from low to high molecular weight proteins has been proposed as a generalized mechanism for the toxicity of those metals. Our results indicated that mercury accumulation by whole gills was related to the mercury-binding activity of low molecular weight proteins, and verified the occurrence of spillover following saturation of such proteins.

\section{ENHANCED TOLERANCE OF MUSSELS TO MERCURY TOXICITY}

We had previously shown that mussels pre-exposed to low levels of mercury $(<0.5 \mu \mathrm{g} \mathrm{Hg} / \mathrm{L})$ develop an enhanced tolerance to acutely toxic concentrations of mercury. This enhanced tolerance was associated with induction of low molecular weight, mercury-binding proteins and binding of mercury to these proteins. Such proteins became saturated with mercury and spillover was observed (e.g., after 28-day exposure to $5 \mathrm{\mu g} \mathrm{Hg} / \mathrm{L})$, mussels did not exhibit the enhanced tolerance. These observations indicated that mussels possess the capability to adapt to low-level exposure to mercury and that the mechanism for adaptation is associated with the mercury-binding activity of specific low molecular weight proteins. Prior induction of these proteins by low-level exposure provided a reservoir of substances whose apparent function is to bind and detoxify metals such as mercury. 
in subsequent experiments, mussels were preexposed to $5 \mu \mathrm{g} \mathrm{Cu} / \mathrm{L}, 10 \mu \mathrm{g} \mathrm{Zn} / \mathrm{L}, 1 \mu \mathrm{g} \mathrm{Cd} / \mathrm{L}$, or a mixture of all three metals, then subjected to a toxic concentration of mercury $(75 \mu \mathrm{g} \mathrm{Hg} / \mathrm{L})$. The objective was to determine if metals (other than mercury), which also induce synthesis of low molecular weight, metal-binding proteins, can confer enhanced tolerance to the toxicity of mercury. The results indicated that the copper pre-exposed mussels developed enhanced tolerance to mercury. Pre-exposure to the mixture of the three metals also resulted in enhanced tolerance, but only to the same degree as that exhibited by the copper pre-exposed group. Since all three metals can induce synthesis of low molecular weight, metal-binding proteins, it was originally expected that all the groups above would exhibit the enhanced tolerance to mercury. However, analysis of tissue samples for copper, cadmium, and zinc indicated that only copper in the copperexposed and copper-, cadmium-, zinc-exposed mussels was accumulated to a level which would result in induction of metal-binding proteins. Thus, only the copper pre-exposure in this study conferred enhanced tolerance to mercury. Additional experiments using higher concentrations of cadmium and zinc for pre-exposure are planned.

\section{IMMUNOLOGICAL ASSAYS FOR LOW MOLECULAR} WEIGHT, MERCURY-BINDING PROTEINS OF MUSSELS

Development of immunological assays for mercury-binding proteins in mussels was initiated on a Battelle Special Studies program, then incorporated into the present research. In these studies, our short-term objective has been to prepare a specific antibody in sufficient quantity to develop immunoassays for measuring levels of mercury-binding protein and for tissue visualization and localization of the protein with light and electron microscopy. The results to date are summarized below.

For the antiserum preparation, two goats were immunized with a suspension of $1 \mathrm{mg}$ of protein mixed with Freud's complete adjuvant. Booster injections of $\sim 0.50 \mathrm{mg}$ protein were given approximately $1,2,4$ and 8 months after the primary immunization. Low antibody titers in the goats were observed using the interfacial ring test and ouchtelony doublegel diffusion.

For the second phase of the studies, bleedings from the goat exhibiting the highest titer of antibody were pooled and used to develop radioimune assays for protein quant if ication and fluorescent-labeled antibody assays.

Two different radioimmunoassay systems were investigated. In the solid phase, double isotope assay system, goat antiHg-binding protein is insolubilized by cross-linking the antibody into a solid matrix using ethyl-chloroformate, then mixed with iodine-125 labeled antigen (i.e., Hg-binding protein). The maximum amount of labeled antigen bound in this system was about $10 \%$. A second and more successful assay system was the double isotope, double antibody system using iodine-125 labeled $\mathrm{Hg}-\mathrm{binding}$ protein, goat antiHg-binding protein, norse anti-goat immunoglobulin, and sodium-22 as a volume marker. The horse antibody serves to maintain the precipitation of the goal antibody at the $100 \%$ level. Initial studies with this assay have demonstrated that $25 \%$ to $30 \%$ of the $\mathrm{Hg}$-binding protein was precipitated by the antibody. Efforts are being made to improve the precipitability of antigen by antibody in the radioimmunoassay.

The indirect fluorescent immunocytochemical technique was used in an attempt to visually locate the mercury-binding protein in gills from mercury-exposed mussels. Basically, the goat antiHg-binding protein is bound to a secondary antibody, horse-antigoat immunoglobulins, that has been conjugated with fluorescein isothiocyanate (FITC). This yields a fluorescent-stained product spec if ic to the mercury-binding protein.

Control mussels and mussels exposed to $5 \mu \mathrm{g}$ $\mathrm{Hg} / \mathrm{L}$ for 28 days were used for initial tests of the immunocytochemical procedures. In preliminary observations, sections of gill tissue autofluoresced a faint white background under incident blue light. Sections from both control and mercury-exposed gills, when incubated with the fluorescent horse anti-goat immunoglobulins alone, showed no fluorescence above background, while those incubated with dilutions of goat immunoglobulins and secondarily stained with horse ant $i-g o a t$ immunoglobulins exhibited an increase. This increased fluorescence was also brighter than that observed following similar dilutions of antibodies from a nonimmune goat.

After the above measures verified the specificity of the horse and goat antibodies, comparisons were made of gill samples from control and mercury-exposed mussels. Sections from both groups showed no obvious differences after treatment with various dilutions of goat 
immunoglobulins and the FITC-labeled horse antibody. These results implied that gills from control (nonmercury-exposed) as well as exposed musseis contained the mercury-binding protein and were consistent with gel chromatographic separations and ouchtelony tests, which showed that low levels of low molecular weight metal-binding proteins occur in tissues of unexposed mussels.

\section{FIELD STUDIES: TRACE METALS IN MARINE} MUSSELS

In the previous year, a study was initiated to identify a population of mussels in Puget Sound that is elevated in trace metals content. We have identified such a population in the vicinity of Tacoma, Washington, and field studies using this population are anticipated. For example, concentrations of $72 \mu \mathrm{g}$ $\mathrm{Cu} / \mathrm{g}, 722 \mu \mathrm{g} \mathrm{Zn} / \mathrm{g}$, and $0.2 \mu \mathrm{g} \mathrm{Hg} / \mathrm{g}$ have been measured in these animals. Respective concentrations for Sequim Bay mussels were $5.2 \mu \mathrm{g}$ $\mathrm{Cu} / \mathrm{g}, 139 \mu \mathrm{g} \mathrm{n} / \mathrm{g}$ and $0.02 \mu \mathrm{g} \mathrm{Hg} / \mathrm{g}$.

EFFECTS OF COPPER ON THE POLYCHAETE, EUDISTYLIA VANCOUVERI

During our previous work, which concentrated on the normal and copper-affected histology of the gill pinnae of Eudistylia vancouveri, it was observed that copper-injured pinnae gradually regenerated during continuous exposure to copper. For example, at $20 \mu \mathrm{g} \mathrm{Cu/L}$ the pinnae eroded and became truncated within 2 or 3 days, but then began to regenerate in 2 to 3 weeks. At 2 months, regenerated pinnae looked the same as those from control worms even though they were still accumulating copper. Cytological structure, revealed by electron microscopy, was similar to that of controls except that the surfaces of the pinnae were rougher, and some epithelial cells contained residual bodies.

It was evident that the worm had developed some protective mechanism against copper. Since low molecular weight, metal-binding proteins are alleged to detoxify heavy metals, the branchial crowns, which include the pinnae, were examined for the presence of such proteins. Preliminary evidence showed that a low molecular weight, copper-binding protein was induced at about the same time the pinnae were observed to begin regenerating. This is the first indication of such a protein in polychaetes. Its induction, concurrent with the start of regeneration, adds evidence to the hypothesis that this kind of protein detoxifies heavy metals.

An experiment to examine this phenomenon in detail was designed and carried out, and the data are still being analyzed. 


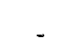

. 


\title{
- Bioavailability of Energy-Effluent Materials in Coastal Ecosystems
}

\author{
Principal Investigator: J. T. Hardy
}

Associate Investigators: R. L. Schmidt and J. E. Rogers

The objective of this research program is to identify and quantify the most important factors controlling the availability of energy-generated materials to marine organisms. Studies focus on processes occurring at important transfer points such as the atmosphere/ocean, water/sediment and water/ organism interfaces.

Research results during the past year indicate: 1)existing information on sea-surface microlayer processes is inadequate to predict the fate or flux rates of metals entering the oceans from atmospheric deposition; 2) in microcosm studies, metals (especially lead) associated with atmospheric particles concentrate in the upper $30 \mu \mathrm{m}$ of the sea surface and may have a relatively long residence time in the microlayer; 3 ) when cadmium is added to seawater containing a natural marine sediment, almost $40 \%$ of the metal binds to the sediment within one minute and is no longer available for accumulation by molluscan gills; 4) sulfide concentrations present in many nearshore benthic environments are great enough to complex cadmium and significantly reduce its availability to shellfish; 5) enhancement of a metal-rich marine sediment with an organic substrate (glucose) can lead to a microbial bloom and rapid solubilization of metals (Ni, $\mathrm{Zn}, \mathrm{Cu}, \mathrm{Cd}$ ) formerly bound to sediment; and 6) clams, Protothaca staminea, concentrate dissolved nickel from seawater primarily through the gills; total accumulation increases linearly with seawater Ni concentrations.

EFFECTS OF SEA-SURFACE MICROLAYER PROCESSES ON THE BIOAVAILABILITY OF ANTHROPOGENIC SUBSTANCES

The sea-surface microlayer (upper $50 \mu \mathrm{m}$ ) controls the transport rates of anthropogenic metal and hydrocarbon substances from the atmosphere to the water column. The microlayer also serves as a sink for hydrophobic organics or particulate-bound materials rising from the water column. The high nutrient and organic content of the microlayer supports an abundant microbiota (neuston), which may actively transform metals or compounds from dissolved to particulate forms or vice versa. Such processes could remove bioavailable contaminants from the water column or, through solubilization, could lead to the ir rapid introduction into marine food webs. Rates of biotransformation, transport; or residence times of metals in the microlayer have not been studied. Our extensive review of recent studies suggests that more information is needed on microlayer processes to assess the importance of air-sea interaction on the fate of anthropogenic substances.

In previous work, we developed a microcosm to study the basic biology of the micro-neuston. We are now using such microcosms in laboratory studies to determine the effects of biotic and abiotic components of surface films on the transport rates of selected contaminants between the atmosphere and the water column.
Neuston communities, mostly pennate diatoms, were grown in flow-through microcosms. One mg of atmospheric particles collected from an urban site was added to separate microcosms, one with a dense neutston community and the other without neuston (pasturized, 0.45-umfiltered seawater), to yield a calculated total exposure concentration of $7 \mu \mathrm{g} / \mathrm{L} \mathrm{Pb}$. The microcosm was incubated statistically outdoors at $15^{\circ} \mathrm{C}$. After 24 hours, water samples were collected from the microlayer (upper $30 \mathrm{\mu m}$ ) with a glass slide sampler and from 7- and 14-cm depths through glass tubes and analyzed for $\mathrm{Pb}$ by atomic absorption. Microlayer $\mathrm{Pb}$ concentrations were higher than subsurface water concentrations regardless of biota densities. However, neuston communities slowed the flux of $\mathrm{Pb}$ to the water column. Lead concentrations per $\mathrm{ml}$ with and without neuston were 3000 and 2000 times greater, respectively, in the microlayer than in the water column (Table 1). The total $\mathrm{Pb}$ retained in the microlayer was about $50 \%$ of the total $\mathrm{Pb}$ in the water column. These results indicate that particulate $\mathrm{Pb}$ entering the oceans from the atmosphere may have a relatively long residence time in the microlayer.

Future studies will determine the rates of biotransformation between abiotic and biotic (dissolved and particulate) compartments within the surface $f i l m$ and the role of marine bacteria in these processes. Results 
TABLE 1. Concentrations of $\mathrm{Pb}$ in the Microlayer and Water Column in Microcosms with $1.05 \mathrm{mg} / \mathrm{L}$ Added Air Particulate Matter

\begin{tabular}{|c|c|c|}
\hline & $\mathrm{Pb}(\mu \mathrm{g} / \mathrm{L})$ & Total Pb $(\mu \mathrm{g})$ \\
\hline Microcosm Sample & $x \pm$ S.E. & $x \pm$ S.E. \\
\hline $\begin{array}{l}\text { Microlayer } \\
\text { with neuston }\end{array}$ & $5004 \pm 1230$ & $0.934 \pm 0.230$ \\
\hline $\begin{array}{l}\text { Microlayer } \\
\text { without neuston }\end{array}$ & $5599 \pm 945$ & $1.045 \pm 0.176$ \\
\hline $\begin{array}{l}\text { Water column } \\
\text { with neuston }\end{array}$ & $1.45 \pm 0.08$ & $1.378 \pm 0.000$ \\
\hline $\begin{array}{l}\text { Water column } \\
\text { without neuston }\end{array}$ & $2.53 \pm 0.08$ & $2.407 \pm 0.016$ \\
\hline
\end{tabular}

should provide, for the first time, realistic estimates of the transport rates of anthropogenic substances between the atmosphere and water column and document the relative importance of neustonic and planktonic communities in determining these rates.

\section{EFFECTS OF MARINE SEDIMENT AND INTERSTITIAL} WATER ON BIOAVAILABILITY OF CADMIUM

Cadmium is an important contaminant that enters the marine environment from both global atmospheric deposition and point source effluents in nearshore coastal areas. Sediments serve as an important sink for removal of dissolved $\mathrm{Cd}$ from the water column. Since bioaccumulation and toxicity of $\mathrm{Cd}$ are believed to be related to the soluble $\mathrm{Cd}^{+2}$ ion concentration rather than to the total Cd, sediment sorption of soluble $\mathrm{Cd}$ may have important implications regarding the bioavailability and subsequent toxicity of $\mathrm{Cd}$ to benthic organisms. Information on the kinetics of $\mathrm{Cd}$ partitioning in marine sediments has been largely limited to artificial sediment mixtures. In addition to the sediment particles, the interstitial water of natural marine sediments is typically high in dissolved organic substances that might complex with $\mathrm{Cd}$ and reduce its bioavailability to benthic organisms. The gills of marine bivalves serve as the major route for bioaccumulation of dissolved trace metals. This fact has lead us to the use of excised bivalve gills as a convenient assay for measuring bioavailability of metals from seawater.

Our studies were undertaken to determine the kinetics of $\mathrm{Cd}$ sorption on a natural marine sediment and the degree to which the sorption and interstitial water might affect bioavailability of cd to gills of the clam Protothaca staminea.

To determine sediment-Cd sorption kinetics, surface sediment was resuspended in natural seawater in a stirred $1-\mathrm{L}$ reaction kettle at $10^{\circ} \mathrm{C}$ under aerobic conditions ( $\mathrm{Eh}=450 \mathrm{mv}$ ) at $\mathrm{pH} 7.9$ to 8.0. Ten $\mathrm{ml}$ of the above sediment slurry was pipetted into a stirred reaction cell containing $200 \mathrm{ml}$ of filtered seawater that was also held at $10^{\circ} \mathrm{C}$. Following stabilization of $\mathrm{pH}$, which was continually monitored, quantities of $\mathrm{CdCl}_{2}$ containing $109^{\mathrm{Cd}}$ were added. Several ten-ml aliquots of the treated slurry were then removed at selected times, between $1 \mathrm{~min}$ and 29 days, and were filtered. Unfiltered aliquots were treated with concentrated $\mathrm{HNO}_{3}$ prior to analysis.

Apparently there are at least four discrete adsorption sites in the sediment, each having a characteristic rate constant and adsorptive capacity (Table 2).

Cd-sediment adsorption also increases with $\mathrm{Cd}$ seawater conentration ( $F$ igure 1 ). Combining data for the four $\mathrm{Cd}$ exposure concentrations yields a model of adsorption with respect to time and initial Cd concentration as follows:

$$
A=0.0438[C d] 0.9873 t^{0.085}
$$

where $[\mathrm{Cd}]=$ initial $\mathrm{Cd}$ concentration in $\mu \mathrm{g} / \mathrm{L}$.

The adsorption rate $R$ is $\frac{d A}{d t}=3.72 \times 10^{-3}$ $[\mathrm{Cd}]^{0.9873} \mathrm{t}^{-0.915}$.

To determine bioavailability, three types of biological exposures were conducted:

1) $0.45-\mu \mathrm{m}$ filtered seawater (control), 2) sediment interstitial water, and 3 ) washed sediment. Sediment interstitial water was

TABLE 2. Kinetics of Cd Adsorption on Sequim Bay Sediment

\begin{tabular}{|c|c|c|c|}
\hline Site & $\begin{array}{c}\text { Rate } \\
\text { Constant } \\
\text { (hr-1) }\end{array}$ & $\begin{array}{c}\text { Estimated } \\
\text { Capacity } \\
(\mu \mathrm{g} / \mathrm{g}) \\
\end{array}$ & $\begin{array}{c}\text { Apparent } \\
\text { Time to } \\
\text { Equilibrium }\end{array}$ \\
\hline$A_{1}$ & $\sim 157$ & 2.8 & $\sim 1 \mathrm{~min}$ \\
\hline$A_{2}$ & 1.33 & 1.9 & $25 \mathrm{~min}$ \\
\hline$A_{3}$ & 0.0457 & 1.6 & $6.6 \mathrm{hr}$ \\
\hline$A_{4}$ & $0.51 \times 10^{-3}$ & 1.0 & $\sim 300 \mathrm{hr}$ \\
\hline Total & & 7.3 & \\
\hline
\end{tabular}




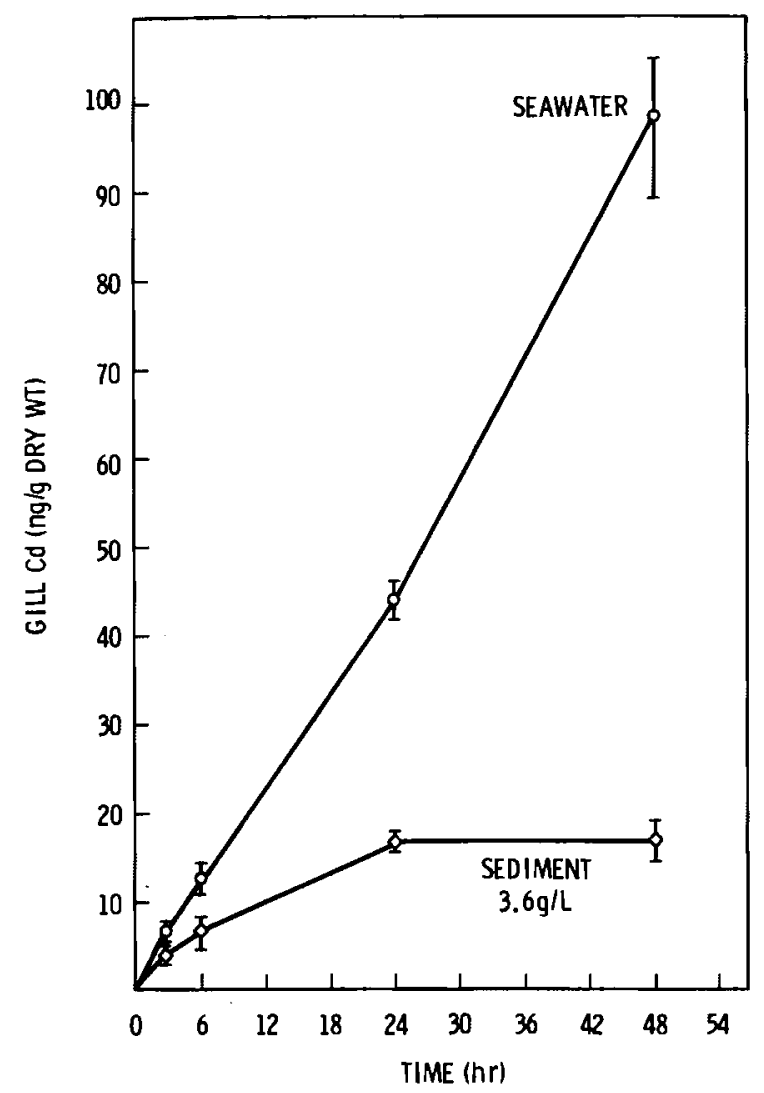

FIGURE 1. Adsorption of Cd on Sequim Bay Clayey Silt as a Function of Time and Initial Concentration of $\mathrm{Cd}$ in Seawater

extracted from Sequim Bay sediment by centrifugation followed by filtration. Littleneck clams (Protothaca staminea) were shucked and the gilis were excised. The radioisotope ${ }_{109} \mathrm{CdCl}_{2}$ was added at $0.37 \mu \mathrm{g} \mathrm{Cd} / \mathrm{L}$. After 17-hour equilibration, one exicsed clam gill was added to each exposure beaker. Following the 17-hour equilibration and again at selected time intervals, the gills and samples of the water were collected and assayed for radioactivity.

In the absence of sediment, clam gills rapidly accumulate $C d$ from seawater. Accumulation is approximately linear over the 48-hour exposure period (Figure 2). The bioconcentration factor $[(\mathrm{ng} / \mathrm{g}$ dry wt $\mathrm{gi} 11) /(\mathrm{ng} / \mathrm{ml}$ seawater) $]=25 \mathrm{X}$ after 48 hours.

Substitution of extracted sediment interstitial water for filtered seawater as the exposure medium had no significant effect on $\mathrm{Cd}$ bioaccumulation compared to the control. The addition of small quantities of washed sediment to the exposure system, however, reduced Cd accumulation by clam gills to only $16.8 \mathrm{ng}$
$5.0 \mathrm{~g} / \mathrm{L}$ DRY SEDIMENT SUSPENDED IN SEAWATER AT $31 \%$ SALINITY, $11^{\circ} \mathrm{C}, \mathrm{pH} 8.0$

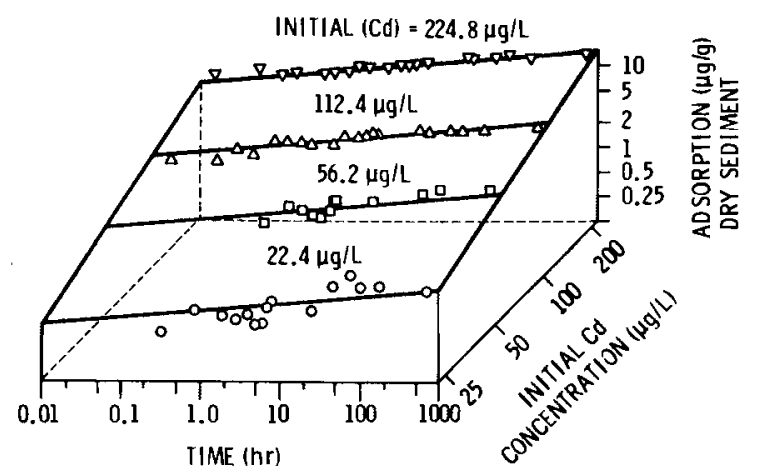

FIGURE 2. Accumulation of Cd by Gills of the Clam Protothaca staminea Exposed to Seawater Only or to Seawater Plus Sediment

Cd/g dry wt in 48 hours, or $17 \%$ of the control. This reduction in bioavailable $\mathrm{Cd}$ in the washed sediment exposure undoubtedly results from the rapid binding of the soluble (bioavailable) Cd fraction to the sediment and its removal from the water.

The $87 \%$ reduction in soluble $\mathrm{Cd}$ after sediment addition corresponds well to the observed reduction in gill Cd accumulation of $83 \%$ in the presence of washed sediment. According to our model for Cd-sediment association (above), after 65 hours with an initial $C d$ water concentration of $0.37 \mu \mathrm{g} / \mathrm{L}$, the sediment should contain $23 \mathrm{ng} \mathrm{Cd/g}$ dry wt. Our measured value for sediment during the gill exposure was $12 \mathrm{ng}$ total $\mathrm{Cd}$ or $34 \mathrm{ng} \mathrm{Cd/g}$ dry sediment. This agreement between the value predicted by the model and that measured in the exposure is reasonably good, considering that the $\mathrm{Cd}$ concentration in the gill exposure was lower than any used to construct the model.

Cd appeared to be strongly bound to the sediment. When sediment containing $32 \mathrm{ng} \mathrm{Cd} / \mathrm{g}$ dry wt was allowed to depurate in clean seawater for 48 hours, it still retained $25 \mathrm{ng}$ $\mathrm{Cd} / \mathrm{g}$.

The increase in total $\mathrm{Cd}$ in the gills exposed in the presence of sediment was insignificant. Given the rapid binding of $C d$ to sediment found in our study and the large reservoir of sediment compared to biomass, low-level additions of Cd to seawater are not likely to lead to significant bioaccumulation through the gills of suspension-feeding bivalves. Thus, bioaccumulation and toxicology experiments that disregard the strong $\mathrm{Cd}-\mathrm{binding}$ capacity of sediments may greatly overestimate the importance of $\mathrm{Cd}$ in natural marine ecosystems. 


\section{INFLUENCE OF SULFIDE ON CD BIOAVAILABILITY}

Low levels of sulfide present in many marine sediments may be great enough to bind metals such as $C d$ and reduce their bioavailability to benthic organisms. Using 0.033 as the fraction of total soluble Cd present as $\mathrm{Cd}^{2+}$ in Sequim Bay water, the Langmuir isotherm $c$ an be used to predict the relative amounts of soluble and bound $\mathrm{Cd}$ :

$$
\begin{aligned}
\frac{\mathrm{Cd}^{2+}}{\mathrm{Cd} \mathrm{Gill}} & =0.650+2.498\left[\mathrm{Cd}^{2+}\right] \\
\text { where }\left[\mathrm{Cd}^{2+}\right] & =\mathrm{Cd}^{2+} \text { concentration in } \mu \underline{M} \\
\mathrm{Cd} \mathrm{Gill} & =\mathrm{Cd} \text { bound to gill in } \mu \underline{M} / \mathrm{g} .
\end{aligned}
$$

A selected quantity of sodium sulfide was added to seawater samples that contained spiked $\mathrm{Cd}$ at several concentrations. Following 1 hour of equilibration, excised clam gills were then exposed to these solutions for 6 hours. At $3.56,7.12$ and $10.7 \mu \mathrm{M}$ total $\mathrm{Cd}$, the uptake of $\mathrm{Cd}$ by $\mathrm{clam}$ gills was reduced to $3.9 \%, 13.4 \%$ and $27.4 \%$, respectively, of the values determined without $5^{2+}$. Using the Langmuir isotherm for $\mathrm{Cd}^{+}$adsorption on clam gills (previous equation), the effective $\mathrm{Cd} 2^{+}$concentrations $c$ an be calculated and the stability constant of Cd-sulfide complexes can be estimated. From these data, the apparent stability constant for the Cd-sulfide complex is $297 \mathrm{~L} / \mathrm{MM}$.

In another experiment, a quantity of $\mathrm{Na}$ sulfide was added to seawater and titrated with Cd. After 1 and 7 hours of equilibration, Cd concentrations were determined by anodic stripping voltammetry. The apparent stability constant from these data is $237 \mathrm{~L} / \mu \mathrm{M}$.

Using the above informtion on $C d$ uptake and complexation, the amount of uptake by clam gills in the presence of $\mathrm{S}^{2-} \mathrm{can}$ be estimated. For example, at $3.56 \mu \mathrm{M}$ total $\mathrm{Cd}$ in the presence of $7.65 \mu \mathrm{M} \mathrm{S} \mathrm{S}^{2-}$, The predicted uptake by clam gills is estimated to be $0.54 \mathrm{\mu g} / \mathrm{g}$. Measured values ranged from 0.43 to $0.61 \mathrm{\mu g} / \mathrm{g}$. This distribution is based on experimental conditions of $10 \mathrm{clam} g i 1 \mathrm{~s} / \mathrm{L}$, each weighing $0.075 \mathrm{~g}$ dry $w \mathrm{t}$.

From preliminary experiments on Cd adsorption by Sequim Bay clayey silt (above section), the adsorption capacity and equilibrium constant of $\mathrm{Cd}$ on this sediment was estimated to be $0.69 \mu \mathrm{M} / \mathrm{g}$ and $4.57 \mathrm{~L} / \mu \mathrm{M}$, respectively. The total Tigand concentration (Total $L_{j}$ ) of an adsorbing species is the product of the adsorption capacity in $\mu \mathrm{M} / \mathrm{g}$ and the amount of adsorbent in $\mathrm{g} / \mathrm{L}$. Equilibrium calculations

show that $\left(\mathrm{Cd}^{2+}\right)$ is $3.3 \%$ of the total soluble $C d$ in Sequim Bay seawater in the absence of sulfide. The remainder is primarily chloro and sulfato complexes. Preliminary experimental data indicate that adsorption capacities and apparent stability constants $\left(K_{i}{ }^{*}\right)$ for $C d$ associated with sulfide, sediment and excised clam gill are as follows:

Ligand

Sulfide

Sequim Bay

clayey silt

Excised clam gill

[6-hr exposure, in $<4.5 \mu \mathrm{MCd} \mathrm{Cd}^{+}$

$(500 \mu \bar{g} / L)]$

Using these values, a model can be constructed that relates the amount of ligand-bound $\mathrm{Cd}$ to the concentration of $\mathrm{Cd}^{2+}$ and the amount of ligand. For sulfide, Sequim Bay clayey silt, and exicsed clam gills, this model is:

$$
\text { Total } \begin{aligned}
\mathrm{Cd}, \mu M / L & =\frac{\mathrm{Cd}^{2+}}{0.033}+\frac{263 \mathrm{~s}^{2-} \mathrm{Cd}^{2+}}{1+263 \mathrm{Cd}^{2^{+}}} \\
& +\frac{3.16 \text { sediment, g/L Cd } \mathrm{Cd}^{2+}}{1+4.57 \mathrm{Cd}^{2+}} \\
& +\frac{1.54 \mathrm{Clamgill}, \mathrm{g} / \mathrm{L} \mathrm{Cd^{2+ }}}{1+3.84 \mathrm{Cd}^{2+}}
\end{aligned}
$$

Concentrations of soluble species are in $\mu \underline{M} / L$.

BIOACCUMULATION KINETICS AND ORGAN DISTRIBUTION OF NICKEL IN A MARINE CLAM

Anthropogenic sources, particularly fossil fuel combustion, currently provide large inputs of soluble and potentially toxic nickel to the marine environment, but little information exists regarding the ability of marine shellfish to concentrate nickel from seawater. Our studies were undertaken to determine the degree of bioconcentration, kinetics of accumulation, and tissue distribution of $\mathrm{Ni}$ in marine clams exposed to seawater enriched with subtoxic levels of $\mathrm{Ni}$. Single excised gills of $\underline{P}$. Staminea were placed in polyethylene beakers with 100 or $150 \mathrm{ml}$ of $0.45-\mu \mathrm{m}-$ filtered seawater. $\mathrm{A} \mathrm{NiNO}_{3}$ solution containing carrier-free $63 \mathrm{Ni}$ was added. 
Whole clams were exposed to $\mathrm{Ni}$ in individual $1-L$ polyethylene beakers containing $800 \mathrm{ml}$ of $0.45-\mu \mathrm{m}-\mathrm{fi}$ tered seawater and $8 \mu \mathrm{g} / \mathrm{L} \mathrm{Ni}$ plus $63^{\mathrm{Ni}}$ at $10^{\circ} \mathrm{C}$ with aeration. To avoid depletion of $\mathrm{Ni}$ from the water, clams were transferred after 24 hours to new media under the same conditions.

Excised clam gills accumulate Ni rapidly from seawater. Accumulation follows biphasic kinetics with an initial rapid rate followed by a second and slower rate. When transferred to low-Ni seawater, $\mathrm{Ni}$ elimination is also biphasic, with a rapid loss from gills during the initial period followed by a slower loss rate during the second period (Figure 3 ). This suggests that there is an easily exchangeable compartment, and probably represents $\mathrm{Ni}$ loosely adsorbed to the gill surface.

The second and slower phases represent biological uptake or binding of the $\mathrm{Ni}$ to a lesseasily exchangeable compartment. Metallothionein-like proteins have been shown to bind metals in invertebrates, but whether or not this occurs for $\mathrm{Ni}$ in $\mathrm{Clam}$ gills has not been demonstrated.

Nickel accumulation in excised gills increases linearly with $\mathrm{Ni}$ levels in seawater such that $A=0.082+0.080 C\left(r^{2}=0.95\right)$ where $A=g i 11$ $\mathrm{Ni}$ accumultion during 3 to 24 hours in $\mathrm{ng} \mathrm{Ni} \mathrm{g}$ dry wt-1 $\mathrm{hr}^{-1}$ and $\mathrm{C}=$ concentration of $\mathrm{Ni}$ in seawater in $\mu \mathrm{g} / \mathrm{L}$. The elimination half-life in excised gills is 59 hours.
The bioconcentration factor (BCF) [(ng Ni/g dry wt gill) (ng $\mathrm{Ni} / \mathrm{ml})]$ can be calculated by using the kinetic approach and dividing the slope of the accumulation by the slope of the elimination equations. This yields a BCF of 4.3X. Whole clams accumulated $30.1 \mathrm{ng} \mathrm{Ni} / \mathrm{g}$ dry wt in 48 hours. This represents a bioconcentration factor of about 4.0X, or only slightly lower than that predicted by the excised gill experiment above. Of the total nickel added, $7.5 \%$ was accumulated by the clam shell. The shell is a major repository for total $\mathrm{Ni}$; it can accumulate more than 7 times as much $\mathrm{Ni}$ as the total soft-body parts.

Measurements of the $\mathrm{Ni}$ contained in individual organs of the clam indicate that concentrations (i.e., ng $\mathrm{Ni} / \mathrm{g}$ dry wt) increase in the following order: adductor muscle < visceral mass < neck + mantle < gills. This order also holds true for the amount of total $\mathrm{Ni}$ contained within each organ. The high concentration of $\mathrm{Ni}$ in the gills of $\mathrm{Ni}$-exposed whole clams indicates that gills are a major site for $\mathrm{Ni}$ accumulation.

$\mathrm{Ni}$ concentrations in the gills of whole clams were three times greater than concentrations in excised gills exposed to the same $\mathrm{Ni}$ concentration for 48 hours. However, the bioconcentration factor for excised gills, calculated from kinetic considerations, still accurately predicts the whole clam bioconcentration of $4 X$ and again indicates that the gills are the major site through which clams concentrate dissolved $\mathrm{Ni}$ from seawater.

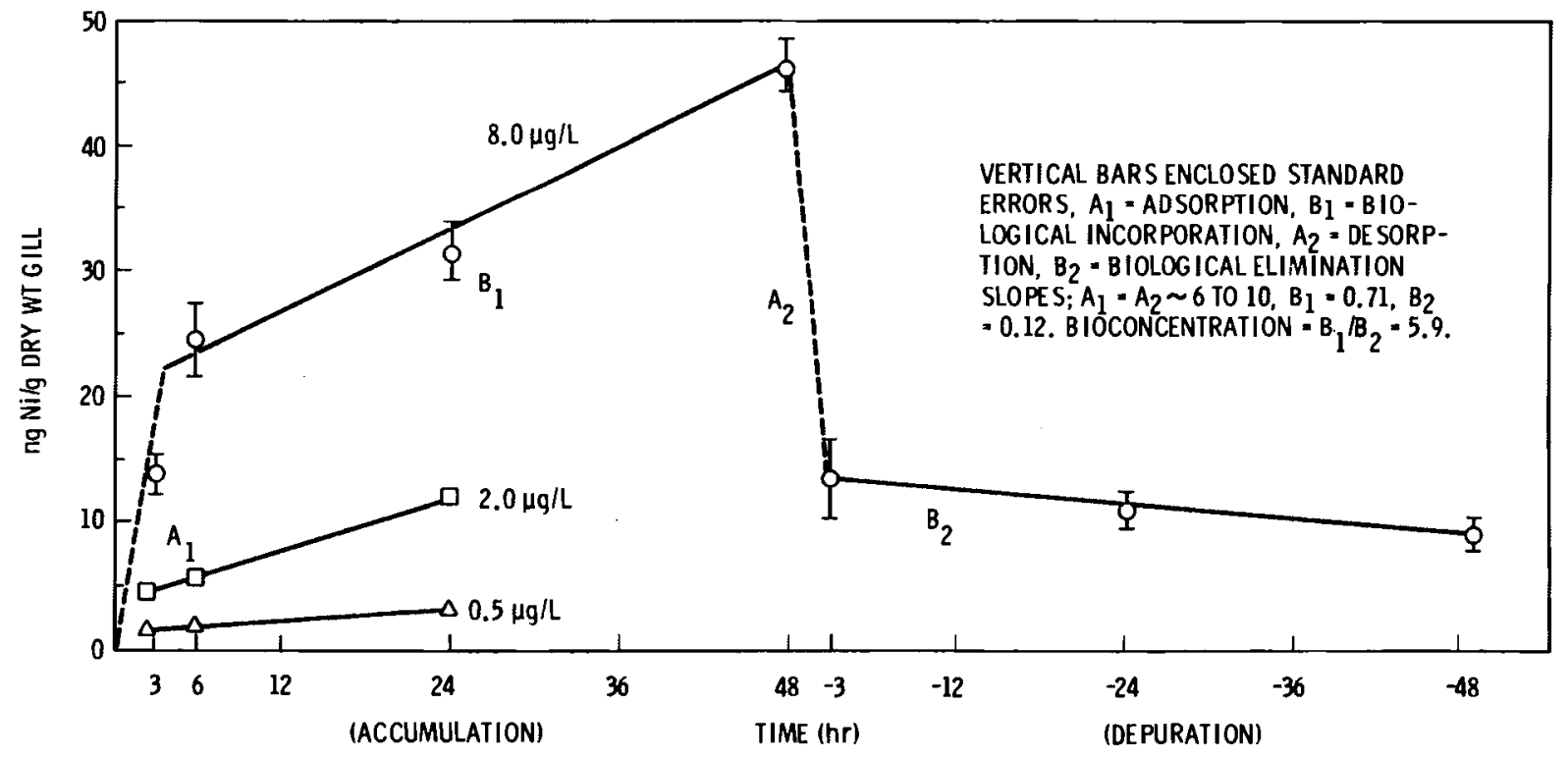

FIGURE 3. Accumulation and Elimination of $\mathrm{Ni}$ by Excised Clam Gills Exposed to 0.5 to 8.0- $\mu \mathrm{g} \mathrm{Ni} / \mathrm{L}$ Seawater 
MICROBIAL SOLUBILIZATION OF TRACE METALS IN MARINE SEDIMENTS

The bioavailability of trace metals to marine organisms, in many cases, is directly related to the solubility and soluble chemical form of the metal. In recent years, much interest has been placed on the role microorganisms play in solubilizing trace metals by altering the $\mathrm{Eh}$ and $\mathrm{pH}$ of the system and in how soluble organic complexing agents are produced from the degradation of organic matter. In this regard, we are investigating how microbial growth alters the solubility of trace metals in marine sediment-seawater slurries. This work has centered on developing an experimental approach that will provide information on microbial factors important to modeling the solubility and mobility of trace metals in marine systems. Initial studies have used sediment slurry incubation systems (1:10 solids-to-liquid ratio) amended at two levels of $\mathrm{Ni}(8.7 \mathrm{ppb}$ and $10 \mathrm{ppm})$, which contained trace levels of $63 \mathrm{Ni}$. Microbial growth was enhanced by amending glucose at $200 \mathrm{ppm}$ carbon. The $\mathrm{pH}$ and $\mathrm{Eh}$ were continuously monitored with time. At specific intervals, sam- ples were removed, filtered through $0.22-\mu \mathrm{m}$ membranes and analyzed for $63 \mathrm{Ni}$ by scintillation spectrometry. The following elements were analyzed by inductive coupled plasma emission spectrometry: $\mathrm{Al}, \mathrm{B}, \mathrm{Ba}, \mathrm{Ca}, \mathrm{Cr}, \mathrm{Cu}$, $\mathrm{Fe}, \mathrm{K}, \mathrm{Li}, \mathrm{Na}, \mathrm{Mg}, \mathrm{Mn}, \mathrm{Mo}, \mathrm{Ni}\left(63_{\mathrm{Ni}}+59_{\mathrm{Ni}}\right)$, $\mathrm{P}, \mathrm{Pb}, \mathrm{Si}, \mathrm{Sr}, \mathrm{Ti}, \mathrm{Zn}, \mathrm{Zr}$, and $\mathrm{Cd}$. Observed changes in $\mathrm{Eh}, \mathrm{pH}$, the solubility of $63 \mathrm{Ni}$, several trace metals ( $\mathrm{Ni}, \mathrm{Zn}, \mathrm{Cu}$ and $\mathrm{Cd}$ ), and the alkaline earths ( $\mathrm{Ca}$ and $\mathrm{S} r$ ) were dependent on the rate of microbial growth as measured by the decrease in glucose concentration. The largest changes correlated with the most rapid decreases in glucose concentration, e.g., decreases in $\mathrm{Eh}$ and $\mathrm{pH}$ and increases in solubility of $63 \mathrm{Ni}, \mathrm{Ni}, \mathrm{Zn}, \mathrm{Cu}, \mathrm{Cd}$, $\mathrm{Ca}$ and $\mathrm{Sr}$. Both $\mathrm{Ni}$ and $63 \mathrm{Ni}$ behaved similarly when amended at $10 \mathrm{ppm}$; however, a marked difference in behavior was observed at $8.7 \mathrm{ppb}$. Apparently, in the latter case, the two Ni fractions represent different sets of $\mathrm{Ni}$ pools. Currently, these results are being evaluated with respect to possible controling factors such as desorption-adsorption, as well as both inorganic and organic complex formation. 


\title{
- Marine Chemistry of Energy-Related Pollutants
}

\author{
Principal Investigator: E. A. Crecelius
}

This program is designed to increase our understanding of the biogeochemical and physical processes that control the fate of energy-generated pollutants that enter the marine environment. As the energy needs of our country increase, coastlines are being used as sites for energy-generating facilities and related industries. As a result, increasing amounts of energy-related pollutants are introduced into the oceans. This research is vital to the U.S. Department of Energy in that it 1) provides baseline data for understanding the natural origins, distributions, and concentrations of trace metals and other contaminants in the oceans; 2) quantifies the input rates and mixing rates of pollutants introduced in the oceans; 3) describes the behavior and fate of anthropogenic pollutants entering the oceans from the atmosphere and the continents; and 4) it assesses the potential environmental impact of energygenerated pollutants on the marine environment.

Currently, the Marine Chemistry Program is concerned with the processes that remove metals and organic combustion products from estuarine waters. Specific tasks pursued during the last year include studies of the solubility in seawater of $7 \mathrm{Be}$, other radionuclides, and metals from air filters; adsorption of the elements on estuarine suspended matter; a comparison of the flux of airborne metals and polynuclear aromatic hydrocarbons to coastal water with the fluxes from rivers and sewage effluent; and the development of new and improved analytical techniques for measuring ultra-low concentrations of elements and compounds in marine samples.

SOLUBILITY BEHAVIOR OF ATMOSPHERIC 7Be IN THE MARINE ENVIRONMENT

Naturally produced, airborne $7 \mathrm{Be}$, which is associated with air particulate matter, is a potentially useful environmental tracer for airborne metals and organic compounds. Experiments were conducted to observe the behavior and fate of atmospheric $7_{\mathrm{Be}}$ in coastal water.

A large-volume air sampler at Quillayute, Washington, was used to collect air particulates at one-week intervals on IPC filters. The collected particles are typical of rural coastal air particulate matter. The filters from a month-long collecton were combined, shredded, and pulverized in a ball mill to ensure homogeneity. The total aliquot was then gamma-counted for all observable radioisotopes on a $\mathrm{Ge}(\mathrm{L} i)$ detector. In addition to data on $7 \mathrm{Be}$, valuable information on bomb fallout radionuclides $(95 \mathrm{Zr}$, $95 \mathrm{Nb}, 137 \mathrm{Cs}$, $124 \mathrm{Sb}, 141_{\mathrm{Ce}}, 54 \mathrm{Mn}$, and $103_{\mathrm{Ru}}$ ) was obtained. After counting the homogeneous filters, we added aliquots to $1-L$ samples of filtered seawater in polypropylene bottles. The samples were vigorously shaken for a selected time period (from 0 to 24 hours) and then filtered through 0.4-micron filters. The filters were then garma counted to obtain the adsorption data.
When air particulates are added to seawater in this way, a large fraction of the $7 \mathrm{Be}$ is quickly solubilized and then readsorbed to the air particulates over a period of hours. This behavior is unlike typical leaching, wherein, after an initial rapid leaching, the leaching continues at an exponentially decreasing rate.

The very rapid leaching, followed by readsorption, is reasonably explained by the acidity of the air particulates: typically, an aliquot of air particulates reduces the $\mathrm{pH}$ of the water by 0.5 units (from 7.8 to 7.3 ). In the vicinity of the particles, therefore, the $\mathrm{pH}$ must initially be much lower, which allows rapid desorption of cations. As the system reaches equilibrium, and the ${ }^{\mathrm{pH}}$ near the particles increases again, the 7 Be shows typical adsorption behavior.

In the ocean, where the concentration of air particulate matter is small compared to natural suspended matter, readsorption on the latter would be an expected result. This was first verified by spiking a seawater extract of air particulate matter with various amounts of natural detritus and observing the $7 \mathrm{Be}$ uptake. In concentrations of 20 to $2500 \mathrm{mg} / \mathrm{L}$ (dry weight basis), $7 \mathrm{Be}$ showed strong adsorption with detritus. A greater adsorption rate was observed with increased detritus, with complete adsorption occurring between 2 and 48 hours. 
Further experiments showed that an artificially produced ionic $7_{B e}$ solution had similar adsortion characteristics, which allowed us to design more rigorous and repeatable experiments, using known quantities of the artificial isotope. One such set of experiments showed that $7_{\mathrm{Be}}$ adsorbs similarly on am$\mathrm{Fe}(\mathrm{OH})_{3}$ and ground shale as with detritus, whereas uptake by a thriving algal culture, Pavlova lutheri (Monochyrsis), was low and variable over time. This leads to the conclusion that $7_{\mathrm{Be}}$ adsorption is a cation exchange phenomenon with inorganic sites on the detritus particles.

Finally, adsorption of $7_{\mathrm{Be}}$ as well as radiotracers of other metals associated with energy processes (lead, silver, cadmium, thallium, zinc, and colbalt) was monitored on natural suspended matter $(0.45 \mathrm{mg} / \mathrm{L})$ over a month-long period. Beryllium-7 was only adsorbed slightly compared to such strongly adsorbed ions as lead and silver. On natural suspended matter, on $7 y$ about $20 \%$ of the 7 Be was adsorbed by the end of the experiment, whereas $210 \mathrm{pb}$ was $>95 \%$ adsorbed by the end of two days. Further measurements of the natural partitioning of $7_{\mathrm{Be}}$ in the marine environment using the Pacific Northwest Laboratory (PNL) largevolume water sampler and $\mathrm{Al}_{2} \mathrm{O}_{3}$ beds gave supportive results. Thus, it must be concluded that $7_{\mathrm{Be}}$ is an unlikely candidate as a tracer for particulate-bound pollutants such as $\mathrm{Pb}$, $\mathrm{Ag}$, or $\mathrm{Hg}$.

ELECTROCHEMICAL ANALYSIS OF SULFIDE IN NATURAL WATERS

A differential-pulse cathiodic-stripping voltametry (DPCSV) analytical procedure was adapted and evaluated for determing low sulfide $(S=)$ concentrations in fresh, marine, and estuarine waters. The technique was successfully used in support of the DOE Oil Shale Field Program in Colorado and the DOE Marine Bioavailability Program at the Sequim Marine Research Laboratory. Accurate measurements of sulfide concentrations are important for modeling chemical speciation, conducting biological studies, and determining bioavailability of metals to marine animals.

Very low sulfide concentrations may be important in the chemical speciation of heavy metals since many metal sulfides have very low solubilities. Trace metals speciation may be affected by sulfide concentrations that now exist, but which are not measurable. The standard spectrophotometric technique for sulfide has a detection limit of $6.4 \mu \mathrm{g} \mathrm{S}=/ \mathrm{L}$. The sulfide-specific ion electrode has a detection limit of $20 \mu \mathrm{g} / \mathrm{L}$. Chemical specia- tion models predict that sulfide may affect silver speciation even at the $0.01 \mu \mathrm{g} S=/ L$ level. Clearly, a sulfide technique that is sensitive at the sub- $\mu \mathrm{g} / \mathrm{L}$ level would be useful. Our present limit of detection using DPCSV is $0.5 \mu \mathrm{g} S=/ \mathrm{L}$.

Our DPCSV method was successfully intercalibrated with two currently accepted techniques using actual environmental samples. A method for simultaneous collection and stabilization of field samples was developed. Determinations of sulfides were made on oxygenated surface seawater (values $<0.5 \mu \mathrm{g} S=/ \mathrm{L}$ ) oxygenated marine bottom water $(2$ to $20 \mathrm{\mu g}$ $S=/ L$ ) reduced interstitial marine water (10 $\mu \mathrm{g}$ $S=/ L)$ and free-freshwater springs (6 to $10 \mu \mathrm{g}$ $S=/ L)$ oxygenated surface streamwater ( 0.2 to $1.9 \mu \mathrm{g} S=/ \mathrm{L})$, and deep well water (1.3 to $31,000 \mu \mathrm{g} \mathrm{S}=/ \mathrm{L})$. The limit of detection for this technique can be expanded to greater sensitivity through adjustment of analytic matrix properties as well as through instrumental modifications.

ATMOSPHERIC DEPOSITION RATE OF METALS AND PAH IN WESTERN WASHINGTON

The flux of airborne metals and polynuclear aromatic hydrocarbons (PAH) to the sea sur$f$ ace has been estimated at three locations in western Washington. A comparison of the atmospheric flux with inputs from rivers and sewage treatment plants shows that the atmosphere accounts for less than $10 \%$ of the $\mathrm{PAH}$, nickel and zinc input, but $72 \%$ of the lead and $40 \%$ of the arsenic. Sewage outfalls contribute approximately $80 \%$ of the PAH inputs.

The atmospheric flux was estimated by applying a total deposition velocity of $0.35 \mathrm{~cm} / \mathrm{sec}$ to the mean concentration of iron, titanium, manganese, nickel, zinc, lead, arsenic, bromide, and four PAH compounds at three sites. The total deposition velocity was selected from previous measurements of air concentrations and atmospheric deposition rates for 14 elements at Sequim and Quillayute. The mean concentrations of elements and PAH at Sequim, Quillayute, and Seattle were determined by collecting monthly high volume air filters at each site during 1979. The filters were analyzed for elements by energydispersive $x$-ray fluorescence and analyzed for PAH by gas chromatography and highperformance liquid chromatography at the University of Washington, Department of Ocenography, by Fred Prahl under the supervision of Dr. Roy Carpenter. The PAH data will also be used on Dr. Carpenter's Department of Energy research project. 
A metals and PAH budget for central Puget Sound was calculated (Table 1) using four conditions. First, we assumed that the atmospheric input rate over Puget Sound is equal to the rate at the Seattle air monitoring station. This is certainly a maximum rate, because areas outside the city have lower air concentrations and would, therefore, have a lower flux. Second, we used the river inputs to estimate the average annual river flows and the seasonal metal concentrations measured by PNL under a contract for Metro of Seattle. The PAH levels in rivers were supplied by Bob Barrick (personal communication) of the University of Washington, Department of Oceanography.

Third, we estimated the input of metals and compounds from sewage outfalls by assuming that the major Seattle outfall (data supplied by Metro) is representative of all other sewage outfalls entering the central Sound. Fourth, the removal rate was determined from age-dated cores. The sediment accumulation rate for the fine-grained mud of the central basin is estimated to be $1.0 \mathrm{~g}$ dry wt $\mathrm{cm}^{-2}$ $\mathrm{yr}^{-1}$, a rate which occurs over only $17 \%$ of the basin. The remaining basin area is covered with coarser sediments that are accumulative at a slower rate. The concentrations of met- als in surface sediments were determined for six cores. The PAH concentrations used to estimate accumulation in the sediments were assumed to be four times the published concentration of PAH in Dabob Bay sediments, according to the recommendations of Fred Prahl (personal communication). The information, which is still lacking from the budget, is the input from other outfalls such as stormwater runoff and advection of seawater in and out of the basin. At the present time, these data are not available.

Considering the inaccuracies in constructing the budget, the agreement between inputs and removal are reasonable, as all agree within a factor of two. The budget does demonstrate that atmospheric input is a small source for PAH and a major source for lead. Sewage effluent is the dominant source of PAH and an important source of metals. The discrepancy between total inputs of metals and removal may be due to overestimation of atmospheric lead flux and overestimation of sedimentation rates. Continuing research at Battelle, the University of Washington, and Metro is directed at reducing the inaccuracy of these fluxes.

TABLE 1. Metals and PAH Budget for Central Puget Sound

\begin{tabular}{|c|c|c|c|c|c|}
\hline \multirow[b]{2}{*}{ Element or Compound } & \multicolumn{4}{|c|}{ Inputs to Puget Sound } & \multirow{2}{*}{$\begin{array}{c}\text { Removal } \\
\text { Accumulation } \\
\text { in Sediments }\end{array}$} \\
\hline & Atmosphere & Rivers & $\begin{array}{l}\text { Sewage } \\
\text { Effluent }\end{array}$ & $\begin{array}{l}\text { Total } \\
\text { Input }\end{array}$ & \\
\hline \multicolumn{6}{|l|}{ Metals $[($ metric tons $) / y r]$} \\
\hline $\mathrm{Ni}$ & 0.84 & 14 & 13 & 28 & 56 \\
\hline Zn & 5.7 & 47 & 29 & 82 & 146 \\
\hline $\mathrm{Pb}$ & 57 & 10 & 12 & 79 & 54 \\
\hline As & 3.6 & 4.5 & 0.9 & 9.0 & 18 \\
\hline \multicolumn{6}{|l|}{ PAH (kg/yr) } \\
\hline Phenanthrene & 11 & 132 & 780 & 923 & - \\
\hline Fluoranthrenes & 20 & 66 & 380 & 466 & 312 \\
\hline Pyrene & 22 & 28 & 160 & 210 & 264 \\
\hline
\end{tabular}




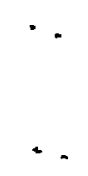




\title{
- Coordination: Pacific Marine Science Program
}

\author{
Principal Investigator: W. L. Templeton
}

In Fy 1981, a workshop on the "Physiological Ecology of Marine Organisms" was organized for the Department of Energy. The workshop provided a forum for the presentation and review of research projects sponsored by DOE in its Marine Biochemical Studies Program. Drs. G. Roesijadi of the Battelle Marine Research Laboratory, Sequim, and H. P. Jeffries of the Graduate School of Oceanography, University of Rhode Island, served as cochairmen of the workshop. Jan Kaps of the Marine Research Laboratory assisted in its organization. The workshop participants included the principal investigators of the individual research projects, invited outside reviewers, and Drs. J. Dorigan, H. McCammon, and H. Hamilton of DOE. Dr. Dorigan is the technical representative responsible for the Marine Biochemical Studies Program. The workshop was held on November 20-21, 1980, in Washington, D.C.

During the workshop, principal investigators presented overviews of their research projects. Discussions included research on perturbations of the environment, uptake of pollutants and their distribution within organisms, criteria of pollutant effects, mechanisms of pollutant action, and detoxification mechanisms.

A major consideration of this workshop was to determine the extent to which the field of physiological ecology can contribute to the understanding of the effects of energy-related activities. Studies should provide an understanding of the upper limits for change that can be assimilated without serious environmental perturbations. Biological approaches assigned high priorities included studies on reproduction and development, physiological and biochemical processes, mechanisms of adaptation, and kinetics. Experiments should be conducted to allow extrapolation to field conditions. The Department of Energy expressed an interest in developing an understanding of generic problems, as opposed to approaches, that are associated with the effects of spe$c$ if ic energy technologies. The research in this program is intended to aid in developing monitoring approaches and to contribute to an overall understanding of the effects that energy-related activities may have on the marine environment.

Outside reviewers submitted summaries of their impressions of the individual projects and the project as a whole to Dr. Dorigan. Other workshop participants were Drs. John D. Costlow, B. Sanders, E. A. Crecelius, J. T. Hardy, Florence Harrison, H. P. Jeffries, Guy McLeon, Trish Morse, G. Roesijadi, Dorothy Spangenberg, Bruce Fowler, Richard Lee, Jerry Neff, Mario Pematmat, B. Schmidt-Nielsen, Ken Sherman, Ken Tenore, K. M. Wilbur, and Mr. J. S. Young. 



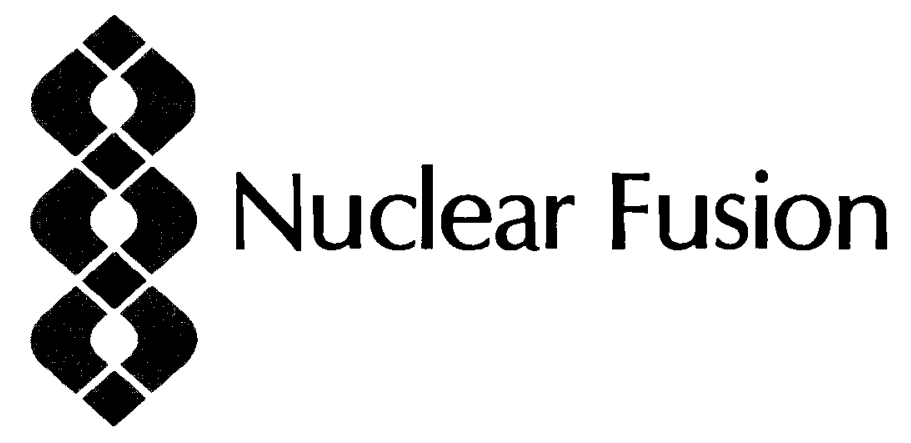





\section{NUCLEAR FUSION}

- Sublethal Effects of Tritium on Aquatic Systems

- Ecological Effects of Lithium and Beryllium on Aquatic Communities

\section{- Teratological Effects of Low-Level Magnetic Fields}

The application of nuclear fusion technology for the production of energy may result in greater quantities of potentially harmful radionuclides being released into the environment. The fusion reactor design is expected to generate significantly greater amounts of tritium than observed in conventional fission reactor designs. Additionally, the demand for specific elements, i.e., lithium and beryllium, may lead to a three- to five-fold increase in mining and milling of materials required in the fusion reactor design. The use of magnetic fields for containment of the fusion reaction may result in the exposure of attendant personnel to magnetic fields of 70 to 450 gause. The research programs described herein respond to the need for defining the potential impacts that their contingencies may impart on aquatic organisms and communities.

Studies addressing the potential effects of tritium on biological systems have used the radiosensitive immune response of the rainbow trout as an experimental endpoint. Current studies, initiated in FY 1979, are focusing on the relative biological effectiveness of tritium radiation $(\beta)$ compared to radioactive cobalt $(\gamma)$.

The incipient toxicity of beryllium sulfate was examined in FY 1981 using rainbow trout embryos and fry. Results of the effects of lithium on production of benthic microflora, macrofauna, and early life stages of rainbow trout were also reported.

The magnetic effects studies are directed at developing different indices for the early detection of sublethal biological effects. Studies in FY 1981 looked at fertilization rates of rainbow trout eggs and sperm exposed to several experimental permutations. Work involving mammalian biology is reported in PNL-4100, Part 1, Biomedical Sciences. Dr. Dennis Mahlum coordinates this comprehensive program. 



\title{
- Sublethal Effects of Tritium on Aquatic Systems
}

\author{
Principal Investigators: J. A. Strand and T. M. Poston
}

It is the purpose of this continuing study to determine the relative biological effectiveness (RBE) of ${ }^{3} \mathrm{H}$ beta irradiation when compared to ${ }^{60} \mathrm{Co}$-gamma irradiation applying the relatively radiosensitive immune process of the rainbow trout, Salmo gairdneri. This study is also designed to investigate the nature of latent expression of immune incompetence in trout exposed to ${ }^{3} \mathrm{H}$-irradiation during embryogenesis.

RELATIVE BIOLOGICAL EFFECTIVENESS OF $3 \mathrm{HOH}$

The purpose of this continuing study is to determine the relative biological effectiveness (RBE) of $3 \mathrm{H}$ beta irradiation when compared to 60 Co gamma irradiation applying the relatively radiosensitive immune process of the rainbow trout, Salmo gairdneri. Previous studies have demonstrated that the primary immune process of rainbow trout was permanently suppressed at ${ }^{3} \mathrm{HOH}$ doses as low as 4 rads total dose delivered over the first 20 days of embryogenesis.

Rainbow trout eggs were exposed to either 0 , $0.5,5.0$ and 50.0 rads $3 \mathrm{HOH}$, or to $0,2.0,20$ and 200 rads 60 Co during the first 20 days of embryogenesis. Each treatment group was divided into three groups and distributed among three separate ponds. At 7-months post hatch, the experimental $\mathrm{fish}$ were vaccinated with a heat-killed strain of Flexibacter columnaris. The development of humoral antibodies was followed for periods of up to 12 weeks following vaccination.

Antibody titers following the initial challenge failed to reach levels observed in prior experiments. The reduced titer levels were initially attributed to use of a less virulent strain of $F$. columnaris. An outbreak of furunculosis in experimental fish stocks also likely perturbed these results.

After obtaining a more virulent strain of $F$. columnaris, the experimental fish were rechallenged at 13-months post hatch. However, the observed immune response in experimental fish following secondary challenge was again significantly different from that observed in previous experiments. Peak titer levels were lower, and control groups did not always display the highest immune response. Again, an outbreak of furunculosis was detected in all ponds. Accordingly, our present plans are to repeat the experiment in its entirety. The fact that we now have access to well water instead of dechlorinated sanitary water should greatly reduce the confounding effects of disease in future studies.

\section{COMPARISON OF TUBE AGGLUTINATION AND MICRO- TITER TECHNIQUES}

A study was performed to compare the sensitivity of antibody detection for the standard tube agglutination test with a newer microagglutination technique. The latter appears to be easier to perform, is less time consuming, and is less expensive.

Two separate populations of $f$ ish were challenged with $F$. columnaris. One group contained $20 \mathrm{f}$ ish individualily marked; the other group consisted of 120 unmarked fish. The individually marked $f$ ish were repetitively bled at 2-week intervals following baseline sampling and vaccination. The unmarked $f i$ sh were sampled ten at a time on a weekly schedule. Serum samples from both groups were subjected to the standard tube agglutination assay and to the newer microtiter methodology. The two methods were compared by using Hotelling's $T^{2}$ statistic for the null hypothesis: $H: \mu$ tube agglutination $-\mu$ microtiter $=0$.

A review of these results revealed that significant $(P=0.05)$ differences were detected over several sampling intervals. However, the differences were random and the two methods were judged to yield comparable results. The data are undergoing additional analysis to confirm this interpretation.

\section{MITOGEN STUDIES}

During FY 1981, the scope of the program was expanded to include use of mitogen stimulation techniques to determine the nature of immune suppression in $3 \mathrm{H}$-irradiated rainbow trout. Preliminary efforts included establishing an assay system for $f i s h$ and determining baseline levels of activity in whole blood, anterior kidney, and spleen. The methods involved preparing cell suspensions in RPMI 1640 tissue culture media containing labeled (iodine-125) iododeoxyuridine (125I-IUDR). The relative degree of stimulation resulting from the addition of $T$-cell mitogens (concanavalin-A and phytohemagglutinin) and pokeweek mitogen (a 
primarily B-cell stimulant) to tissue cultures is determined by measuring the incorporation of $125 \mathrm{I}-\mathrm{IUDR}$. The finding that $t$ issue cultures from irradiated $f$ ish exhibit a lower response to mitogens may suggest that radiation injury was manifest in the differentiation of fewer stem cells. It follows that fewer stem cells upon antigenic stimulation proliferate fewer peripheral cells.

In vitro mitogen-induced assays in the whole blood of trout were complicated by clotting of the red blood cells. Efforts to eliminate this problem by adding heparin were unsuccessful. It appeared that whole blood cultures responded to the three mitogens tested; however, the clotting problem caused highly variable results and elevated baseline values. Assays with fish blood will probably require separation of lymphocytes from red blood cells prior to mitogen assays. The spleen tissue preparations were the most responsive to the mitogens tested. The greatest degree of stimulation was observed with phytohemagglutinin after 5 days of incubation at $20^{\circ} \mathrm{C}$. The degree of stimulation observed in the anterior kidney was low for the three mitogens due to high baseline values. It is possible that the high baseline values were caused by the presence of red blood cells in the tissue preparation.

Once the assay methodology has been perfected, experimental groups of fish from cobalt and tritium exposures described above will be sampled to determine if this method $c$ an also detect inhibition of the immune system. 


\title{
- Ecological Effects of Lithium and Beryllium on Aquatic Communities
}

\author{
Principal Investigator: T. M. Poston
}

The purpose of this study is to examine the ecological significance of elevated concentrations of lithium and beryllium in freshwater systems.

Studies with beryllium focused on the effects of beryllium sulfate $\left(\mathrm{BeSO}_{4}\right)$ on the ontogeny and survival of early life stages of rainbow trout. The toxic endpoints are: egg integrity, fertilization success, completion of embryogenesis, hatchability, fry survival, and juvenile survival. Although the earlylife-stage data are currently being analyzed, preliminary inspection of the data suggests that for endpoints prior to hatching, the developing eggs are responding to toxicity of $\mathrm{Be}^{+2}$, acidification of the exposure solutions caused by the addition of $\mathrm{BeSO}_{4}$, or a syner- gistic effect of both factors. Acute toxicity (96-hour static exposures) of $\mathrm{BeSO}_{4}$ on juvenile rainbow trout occurs at $<1.0 \mathrm{ppm} \mathrm{Be}{ }^{+2}$. This concentration does not result in acidification of the exposure solution, which suggests that the egg stages are less sensitive to $\mathrm{Be}^{+2}$ than are the larval stages.

Testing of $\mathrm{BeSO}_{4}$ will continue with representatives from several phyla. The testing will help us to better understand potential ecological effects. These studies will be completed and reported in FY 1982. 



\title{
- Teratogenic Effects of Low-Level Magnetic Fields
}

\author{
Principal Investigators: J. A. Strand and C. S. Abernethy \\ Associate Investigators: J. R. Skalski and R. G. Genoway
}

Initial studies conducted at this laboratory suggested that the fertility of trout eggs could be affected by magnetic fields of 1 tesla $(T)$. Additional studies were performed to confirm these results and to examine the relative susceptibility of eggs and sperm to magnetic fields. Preliminary results and an interpretation of the data are presented below.

EFFECTS OF MAGNETIC FIELD EXPOSURE ON FERTILIZATION OF RAINBOW TROUT, SALMO GAIRDNERI

Magnetic fields of $1 \mathrm{~T}$ or higher might be employed in the new generation of fusion reactors to conf ine high-temperature plasmas. Although magnetic fields will be considerably reduced outside the main reactor area, it is conceivable that magnetic fields of 0.007 to $0.0450 \mathrm{~T}$ wil1 be encountered by attendant personnel working in the transport and hot cell areas of the reactor. Also, those personnel assigned to the areas immediately surrounding the reactor may be exposed for substantial durations to field strengths of 0.001 to $0.007 \mathrm{~T}$.

Four to six 3-year-old female fish were spawned, yielding $6000(600 \mathrm{ml})$ eggs. The eggs were well mixed and immediately divided into two equal portions in glass beakers. Sperm $(30 \mathrm{ml})$ from four to six 3-year-old male $f i s h$ were gathered in a glass beaker and immediately divided into two vials. Eggs and sperm were extruded using the "dry method," which eliminated any contact between gametes and water.

Eggs or sperm were placed within the 1-T homogeneous magnetic field for one hour. Ice packs around the glass beakers containing eggs or sperm maintained temperature at an acceptable level $\left(12.0 \pm 0.5^{\circ} \mathrm{C}\right)$. Control eggs and sperm were sham-exposed.

After a one-hour exposure, eggs were fertilized according to the following combinations:

- eggs $\times$ sperm

- eggs* $\times$ sperm

- eggs $x$ sperm*

- eggs* $\times$ sperm .

Eggs and sperm were well mixed and allowed to stand for two minutes. The eggs and sperm mixture was then rinsed, reconstituted, and water-hardened for one hour. Eggs and sperm were later transferred to a standard drip incubator (Heath-Techna Corp., Kent, Washington) where they were incubated for 7 days at $12.0 \pm 0.5^{\circ} \mathrm{C}$. At the end of 7 days, they were sacrificed and preserved in Stockard's solution. Stockard's was used to clear the eggs and etch the embryo for scoring. Scoring was done in the "blind;" the eggs being scored were either fertile or infertile.

Fertility between control and exposure groups was compared using the Z-statistic. Additional comparisons were made applying the distribution-free sign test ( $F$ isher).

Experimental results in Table 1 show that in five independent experiments where eggs alone were exposed to the magnetic field, fertilization was significantly $(a<0.001)$ enhanced. Egg fertility in three of eight experiments was significantly $(\alpha<0.002)$ enhanced when sperm alone were exposed to the magnet ic field. Statistical analyses of nine independent experiments (Table 1) confirm that fertilization is enhanced $(\alpha<0.001)$ when both egg and sperm are exposed to the magnetic field prior to fertilization. A combined analysis (not shown in Table 1) of all experiments conducted over a two-year period revealed a significant $(\alpha<0.001)$ increase in fertilization success among magnetic-field ( $1 \mathrm{~T}$ for 1 hour) exposed groups.

Although the differences are not great, they are statistically significant. According to the sign test, the probability that eight of nine trials where both gametes were exposed would result in enhanced fertilization is $\alpha=0.0341$. In other words, the probability of observing eight heads or eight tails in nine flips of a coin due to chance alone is 0.03 . Thus, even being as conservative as possible, the experimental results demonstrate a significant effect attributable to magnetic field exposure. 
TABLE 1. Percent Fertility of Eggs, Sperm, or Eggs and Sperm Exposed to a $1 \mathrm{~T}$ Magnetic Field

\begin{tabular}{|c|c|c|c|c|}
\hline Test No. & Control & Exposed & Z-Statistic & a-Level \\
\hline \multicolumn{5}{|l|}{ Eggs } \\
\hline B-1 & 97.25 & 97.25 & 0.0086 & 0.9931 \\
\hline B-2 & 93.51 & 96.03 & -4.0865 & 0.00004 \\
\hline B-3 & 93.23 & 95.39 & -3.3892 & 0.0007 \\
\hline 6 & 87.52 & 97.14 & -11.6652 & 0 \\
\hline 9 & 91.90 & 91.38 & 0.5655 & 0.5717 \\
\hline Mean & & & -8.3034 & 0 \\
\hline \multicolumn{5}{|l|}{ Sperm } \\
\hline B-1 & 97.25 & 96.45 & 1.6963 & 0.0898 \\
\hline B-2 & 93.51 & 93.54 & -0.0493 & 0.9706 \\
\hline B-3 & 93.23 & 93.45 & -0.3231 & 0.7466 \\
\hline 6 & 87.52 & 89.72 & -2.2275 & 0.0259 \\
\hline 9 & 91.90 & 92.78 & -0.9954 & 0.3195 \\
\hline D-1 & 72.47 & 72.80 & -0.2143 & 0.8303 \\
\hline D-2 & 96.33 & 97.46 & -2.1150 & 0.0344 \\
\hline D-3 & 53.58 & 61.60 & -4.5704 & 0 \\
\hline Mean & & & -3.1108 & 0.0019 \\
\hline \multirow{2}{*}{\multicolumn{5}{|c|}{$\begin{array}{l}\text { Eggs and } \\
\text { Sperm }\end{array}$}} \\
\hline & & & & \\
\hline A-1 & 97.64 & 98.72 & -4.1016 & 0.00004 \\
\hline A-2 & 97.69 & 98.55 & -3.6858 & 0.0002 \\
\hline$A-3$ & 99.07 & 99.10 & -0.1518 & 0.8793 \\
\hline$A-4$ & 98.00 & 98.60 & -2.3605 & 0.0183 \\
\hline B-1 & 97.25 & 97.01 & 0.5356 & 0.5922 \\
\hline B-2 & 93.51 & 95.95 & -3.8730 & 0.0001 \\
\hline B-3 & 93.23 & 97.09 & -6.5814 & 0 \\
\hline 6 & 87.52 & 97.08 & -11.7707 & 0 \\
\hline 9 & 91.90 & 93.83 & -2.2652 & 0,0235 \\
\hline Mean & & & -11.4181 & 0 \\
\hline
\end{tabular}

LATENT EFFECTS OF MAGNETIC FIELD AND CHLORINE EXPOSURE ON GROWTH OF JUVENILE RAINBOW TROUT, SALMO GAIRDNERI

A feeding study was conducted with juvenile rainbow trout that had been exposed as embryos for 21 days to one of four conditions: a) a high-density, homogenous magnet ic field ( $1 \mathrm{~T})$; b) a continuously maintained 50-ppb TRC concentration of chlorine (sodium hypochlorite); c) both the magnetic field and chlorine; d) neither variable (control). After exposure, the embryos were transferred to a vertical flow incubator and maintained for two weeks after hatching. At that time, the fry from each treatment were divided into four equal groups and placed in four fiber glass troughs. Each trough consisted of four compartments; each compartment received one test group forming a $4 \times 4$ Latin Square design. Survival was monitored for three months, at which time the $f$ ish were 8 to $10 \mathrm{~g}$ in weight. No significant differences in survival were observed.
In September 1980 , sixty fish from each compartment of the four troughs were branded with liquid nitrogen to identify both their treatment and position in the Lat in Square. of these sixty fish, 25 were placed in each of two 4-foot diameter fiber glass circular tanks at $15^{\circ} \mathrm{C}$. The remaining ten $f$ ish were sacrificed for initial weight-length measurements (Table 2). Each circular pond contained a total of $400 \mathrm{fish}$ (100 from each treatment and 25 from each of the four positions in the Lat in Square).

The feeding study was designed to measure two parameters: the growth potential and the competitiveness of each group. One tank was fed $3.0 \%$ of their body weight/day, 5 days/week, which allowed maximum growth and supplied adequate food to satiate all individuals in the tank. The other tank was fed $1.5 \%$ of their body weight/day, 5 days/week--a restricted level in which growth was dependent upon competition for a limited food supply. Weekly grab samples from each tank were weighed, and any necessary adjustments in food availability were made to maintain the $1.5 \%$ and $3.0 \%$ feeding schedule. After 4 weeks, ten fish from each group in each tank ( 40 per treatment) were anesthetized, weighed, measured, and returned to the tank. At 8 ,weeks, all $\mathrm{f}$ ish were anesthetized, weighed and measured, and the test was terminated.

The length and weight data taken at 8 weeks are shown in Table 3 . The fish in the wellfed tank ( $3.0 \%$ body weight/day) exhibited no significant difference among treatments in terminal weight or length, which suggests that the chlorine and magnetic exposure did not af fect growth potential. In the tank fed $1.5 \%$ body weight/day, the fish exposed to the magnetic fields were significantly smaller than those exposed to chlorine. The fish were also smaller than the fish in the control group. These data suggest that fish exposed to the

TABLE 2. Length and Weight of Fish at Beginning of Feeding Study

\begin{tabular}{|c|c|c|c|}
\hline Treatment & $\mathrm{N}$ & $\begin{array}{c}\text { Mean } \\
\text { Length, } \mathrm{mm}\end{array}$ & $\begin{array}{c}\text { Mean } \\
\text { Weight, } g \\
\end{array}$ \\
\hline Control & 40 & 101.2 & 11.58 \\
\hline Chlorine-exposed & 40 & $99.4 \mid$ & 11.08 \\
\hline Magnet-exposed & 40 & $96.9 \mid$ & 10.09 \\
\hline Chlorine-magnet exposed & 40 & 96.6 & 9.97 \\
\hline
\end{tabular}

Note: Bars indicate groups that are not statistically different. 
TABLE 3. Terminal Lengths and Weight of the Four Treatment Groups under Optimal and Restricted Feeding Regimes

\section{Mean Mean \\ $\mathrm{N}$ Length, $\mathrm{mm}$ Weight, $\mathrm{g}$}

Optimal Feeding (3\%)

Treatment

Control

Chlorine-exposed

Chlorine-magnet exposed 100

Magnet-exposed

100

147.0

147.9

147.5

146.0

Restricted Feeding (1.5\%)

Treatment

Control

Chlorine-exposed

Chlorine-magnet exposed 100

Magnet-exposed

100

$\begin{array}{ll}100 & 127.2 \\ 100 & 125.9 \\ 100 & 125.1 \\ 100 & 123.5\end{array}|| \begin{aligned} & 22.26 \\ & 21.46 \\ & 21.20 \\ & 20.56\end{aligned}||$

Note: Bars indicate groups not significantly different. magnetic field had a competitive handicap. However, statistical examination of the first size data (Table 2) indicates that similar differences were present at the beginning of the study. This finding somewhat confounds the interpretation of the data. Nonetheless, it was concluded that under optimal conditions of diet $(3.0 \%)$, fish exposed to magnetic fields compete equally well with control fish. That is, magnetic-field fish conpensate for initial differences in length and weight. Under conditions of restricted diet $(1.5 \%)$, however, the fish apparently do not compensate.

The size difference at the beginning of the test may be attributable to magnetic field exposure, as the positioning of the Latin Square did not produce much effect. However, this hypothesis cannot be statistically verified without further replication. The rapid rate at which trout grow under optimal conditions makes it difficult to detect minor changes in growth rate. Tests to measure growth under optimum and restricted diets are again planned for FY 1982. 


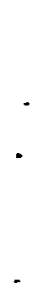


Pumped Storage
and Hydroelectric
Development 
. 


\section{PUMPED STORAGE AND HYDROELECTRIC GENERATION}

\section{- Effects of Hydroelectric Generation on Riverine Ecology}

Adverse effects of hydroelectric generation on aquatic ecosystems have rarely been quantified in a continuing research program related to full development and use of hydroelectric resources. Strict regulation of river flows in response to variable power needs at river-run dams, creation of new impoundments for hydroelectric generation and water conservation, and accelerated development of pumped storage reservoirs combine to increase the amount of riparian areas affected by unnatural water-level fluctuations. Periodic and/or irregular changes in water levels, which flood and expose vast stretches of shoreline, may exert detrimental effects on some aquatic populations unless fluctuations are controlled during crucial biotic periods.

The problems related to acute changes in water levels exist at almost all hydroelectric sites and represent, in a broad sense, generic impacts. However, the magnitude of effect varies on a site-by-site basis because of differences in fish and invertebrate species present, season of year relative to shoreline use by important species, geographical location, shoreline extent and topography, types of riparian substrate and vegetation, and other factors. Known specific effects include reduction of primary production, destruction of fish food organisms, and losses of eggs, fry and adult fish due to entrapment, stranding, desiccation, and increased vulnerability to predators. Water quality may also be influenced by scouring and siltation, changes in temperature regimes, and excessive dissolved gas levels.

From a broad view, the project contributes to resource management concepts required for consideration of nearly all industrial uses of water, consumptive and nonconsumptive. There will be a possible swing, at the government level, to renewed emphasis on nuclear fission. Since increased power production by nuclear fission requires increased use of available water resources, even greater regulation of stream flows may be required. 



\title{
- Effects of Hydroelectric Generation of Riverine Ecology
}

\author{
Principal Investigators: C. D. Becker and D. H. Fickeisen \\ Other Investigators: D. A. Neitzel, D. C. Klopfer and C. S. Abernethy
}

Our objective is to examine the ecological consequences of water-level manipulation that result from intensified hydroelectric power generation on aquatic resources and riparian communities. Impacts on critical species and critical life stages are emphasized. The research reported here addresses the effects of abrupt, short-term (daily and weekly) cycles in water level on fish, particularly in regard to production of valued commercial, sport, and Indian subsistent and ceremonial species. The tasks are not only designed to identify impacts of water-level fluctuations but to provide quantitative data, when possible, and to suggest means of mitigation for protecting valuable species at periods crucial to their survival.

Major accomplishments of this program over the past two years include: 1) assessment of water-level and temperature changes that affect spawning of smallmouth bass, 2) identification of ecological impacts associated with water-level fluctuations in the Columbia River at Hanford from power peaking operations at an upriver dam, 3) quantification of dewatering regimes that are detrimental to intergravel phases of chinook salmon, and 4) initial development of a generic model for accessing the impact of water-level fluctuations.

The program is integrated with needs of several federal organizations (Corps of Engineers, Fish and Wildlife Service, Water and Power Resource Service, Federal Energy Regulatory Commission) and state agencies (Departments of Fisheries, Game, Ecology and Natural Resources).

\section{WATER-LEVEL FLUCTUATIONS}

Observations on effects of water-level fluctuations (WLF) have been made in the Hanford reach of the Columbia River for a number of years. Abrupt water-level changes occur daily and weekly from a power peaking mode of operation at an upriver dam (Figure 1 ). Such fluctuations are now typical at hydroelectric sites because power generation is intensively regulated for maximum production during peak load demands. Thus, the impacts defined in our research and the methods developed for the task have broad application.

The faunal region particularly sensitive to WLFs is the shoreline or eulittoral zone. Benthic fauna with limited mobility can be stranded by receding water and subject to entrapment, desiccation, oxygen and thermal stress, or to predation as water levels gradually change.

Fish populations are more susceptible to WLFs because they rapidly reenter covered shorelines during high water and are subjected to stranding, entrapment, desiccation and predation on a daily and weekly basis. We found that juvenile fish are more susceptible than adult fish to WLF impacts. However,

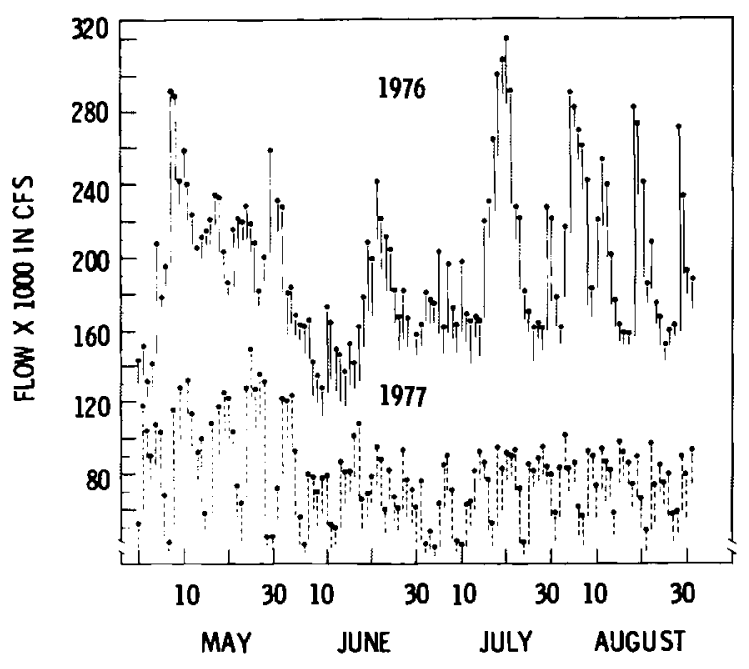

FIGURE 1. Daily Columbia River Flow Patterns Past Priest Rapids Dam from May through August 1976 (a high-flow year) and 1977 (a low-flow year). To convert cfs (cubic feet per second) to $\mathrm{m}^{3} / \mathrm{s}$, multiply by 0.0283 . 
estimates of actual losses are conservative because relatively few fish known to be present before dewatering $c$ an be found after the water withdraws. Thus, quant if ication of impacts on fish populations is difficult, and new methods need to be developed.

The most valued fish species influenced by WLFs at Hanford are anadromous fall chinook salmon (Oncorhynchus tshawytscha) and the resident smallmouth bass (Micropterus dolomieui). Crucial periods for chinook salmon occur during winter, when incubating eggs are in the gravel, and during emergence in the spring, when fry are abundant in shoreline areas. The crucial period for smallmouth bass is during spring and early summer when adults spawn in warmed sloughs and shoreline areas.

Chinook salmon and smallmouth bass fry are vulnerable to stranding and entrapment, and smallmouth bass nests are susceptible to exposure and temperature changes resulting from repeated water-level fluctuations. Thus, flow manipulation may be crucial to their survival. On a generic basis, other critical species and critical periods may occur in different geographical areas, and these occurrences will need to be identified wherever water levels are manipulated by man.

Modeling Water-Level Fluctuations. We have an extensive data base concerning water-level and temperature changes at three stations in the Hanford Reach during spring and summer. These data are supplemented by observations on: shoreline exposure, smallmouth bass spawning and reproduction success, and fish and invertebrate stranding. The data are also supplemented by elevation surveys and electroshocking results. This data base, together with flow release data at Priest Rapids Dam, provides information to develop a predictive mathematical model on effects of water-level fluctuations and, thereby, address generic impacts related to hydroelectric generation. Development of the model has been initiated.

\section{SALMON REDD DEWATERING}

In addition to water-level fluctuations caused by power peaking, alterations in stream flow are also caused by consumptive uses of water such as irrigation, pumped storage projects, and filling of new or drought-depleted reservoirs. As a result of flow manipulation, salmonid eggs and alevins developing over winter in the gravel of stream beds may be dewatered for various periods. Such impacts have been documented, and may become more frequent with development of low-head hydroelectric projects on Northwest streams.

Our research objective is to evaluate the effect of dewatering on survival and development of chinook salmon eggs and alevins in the artificial gravel redds. The redds consist of glass aquaria containing a gravel mix and supplied with 4 liters of water per minute at $10^{\circ} \mathrm{C}$. Cleavage eggs and embryos (the egg phases) and eleutheroembryos and advanced alevins (the alevin phases) were dewatered 20 consecutive times in 22-day tests. The egg phases were more tolerant than the alevin phases (Figure 2). Some cleavage eggs were killed by 12- and 16-hour dewaterings, but embryos survived up to 22-hour daily exposures. In contrast, about half the eleutheroembryos were killed by 4-hour daily dewaterings, and nearly all advanced alevins were killed by 1-hour daily dewaterings.

The tolerance of embryos was tested in other ways. Embryos survived extended, multiple dewaterings (over $60 \%$ survival for four consecutive 118-hour periods) and one-time, continuous dewatering for 12 consecutive days (over $80 \%$ survival).

Intergravel temperatures were affected by insolation and air temperature during early fall studies with cleavage eggs; lethal intergravel temperatures limited cleavage egg survival. Growth of egg phases from some females was retarded by dewatering, but this phenomena was not consistent for all egg groups. The size of surviving eleutheroembryos decreased as the length of daily dewatering periods increased. 


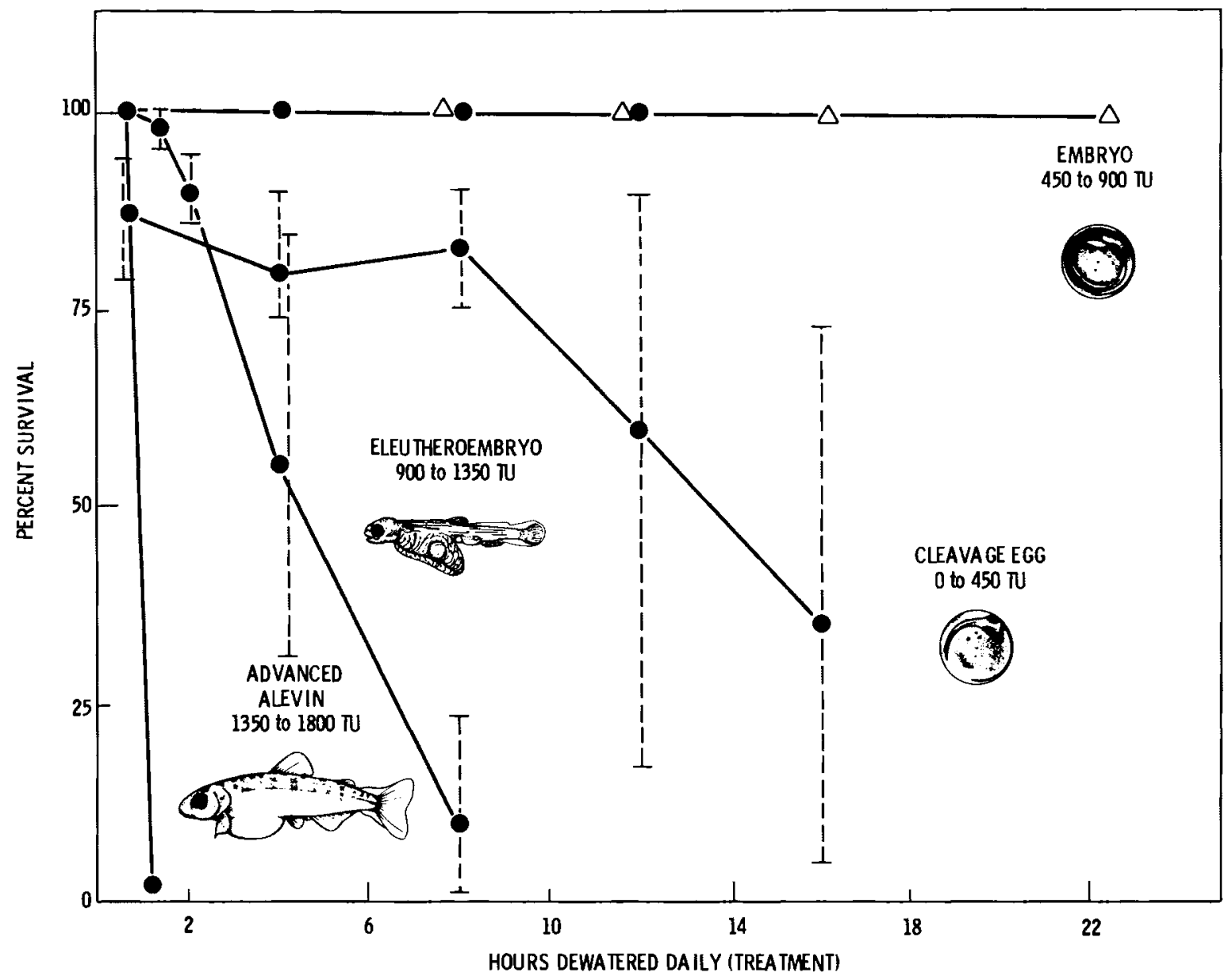

FIGURE 2 Comparative Tolerance of Four Intergravel Developmental Phases of Chinook Salmon to Dewatering (based on 20 consecutive dewaterings in 22 days). Survival of cleavage eggs was limited by intergravel warming from insolation. 


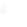

- 


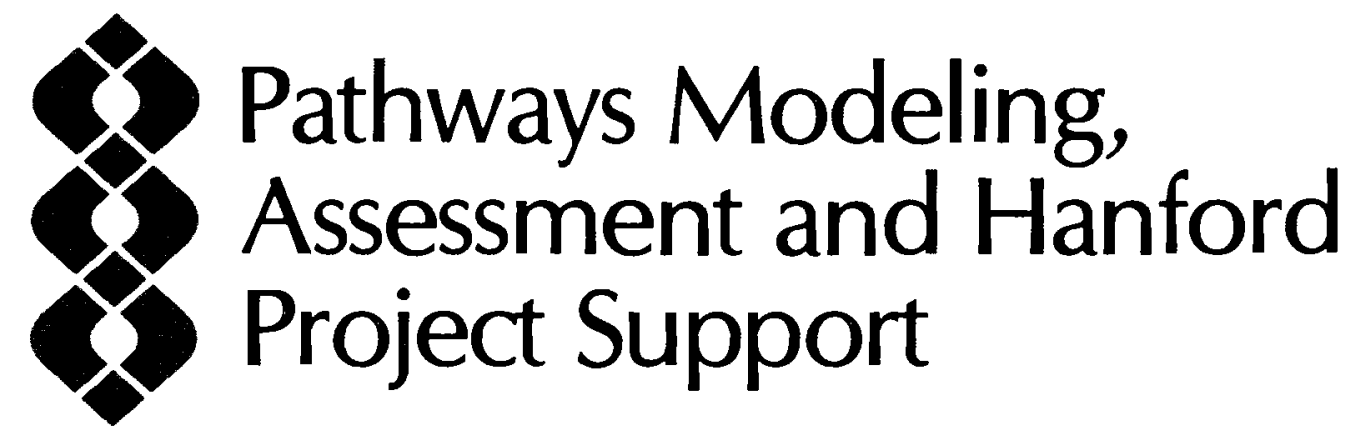




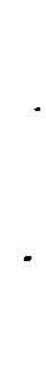




\section{PATHWAYS MODELING, ASSESSMENT AND HANFORD PROJECT SUPPORT}

- Assessment of Effectiveness of Geologic Isolation Systems(a)

- Hanford Defense Waste Studies(a)

- Service Assessment Studies(b)

- Power Plant Fuel Conversion Environmental Impact Assessment(a)

- Standardized Input for Hanford Environment Impact Statements(a)

- PUREX/Uranium Oxide Startup(a)

- Review of Soil Contamination Guidance(b)

- Preliminary Radiation Dose Analysis for Reference FUSRAP Waste Sites

- Environmental Assessment for Advanced Isotope Separation

This section describes related environmental studies funded by DOE, particularly those organized in support of nuclear waste management responsibilities of the Office of Nuclear Waste Isolation (ONWI) and those funded from local sources. The studies are designed to 1) ascertain the potential for uptake and transport of waste radionuclides away from shallow low-level waste burial grounds located on the Hanford site, 2) develop techniques for guarding burial grounds against biotic penetration, 3) monitor over long intervals the several most important animals likely to be affected by industrial development of the Hanford site, and 4) provide dose calculations for safety assessment purposes for various options under consideration in nuclear technology development.

(a) DOE work performed by Ecological Sciences Department under intralaboratory work order.

(b) DOE work performed by Ecological Sciences Department under intercontractor work order, or task agreement with Richland Operations Office (DOE). 


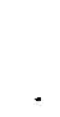




\title{
- Assessment of Effectiveness of Geologic Isolation Systems(a)
}

\author{
Principal Investigators: J. K. Soldat and B. A. Napier
}

The program for Assessment of Effectiveness of Geologic Isolation Systems (AEGIS) is managed through Pacific Northwest Laboratory's Water and Land Resources Department and is funded through the Battelle Office of Nuclear Waste Isolation (ONWI). The Ecological Sciences Department was involved in two subtasks under AEGIS: Dose Methodology Development and Reference Site Initial Analysis (RSIA) for a Salt Dome.

\section{DOSE METHODOLOGY DEVELOPMENT}

Work was completed on a code DITTY 1 for the calculation of long-term, integrated (104 years) population doses from radionuclides reaching the biosphere from a waste disposal site. Development of this code was also funded by the Department of Energy's Richland Operations Office (DOE/RL) through the Hanford Defense Waste Environmental Impact Statement project.

Documentation of the DITTY1 code is scheduled for the first quarter of FY 1982. The code was used during an evaluation of the U.S. Environmental Protection Agency's (EPA) proposed standard (40 CFR 191) for disposal of highlevel and transuranic waste in geologic media. A calculation was made of the potential health effects resulting from the release to the accessible environment of the limiting amounts of each radionuclide listed in the proposed EPA standard. In the absence of the EPA report which discussed their exposure scenarios and dose code, the calculations were performed for five sitelexposure mode combinations:

- direct consumption of the entire allowable release by a single person

- contamination of wells at the site boundary with about 200 persons consuming contaminated water and irrigated foods

- three scenarios based on a Hanford-type site with the released quantities of each radionuclide being diluted in a river flow of $10^{5} \mathrm{cfs}\left(0.0283 \mathrm{~m}^{3} / \mathrm{s}\right)$. In case 3 , the nuclides were released to the river uniformly over the 104-year period; in case 4, they were released uniformly over the first $10^{3}$ years; and in case 5 , they were released over the last $10^{3}$ years.
The direct ingestion case represented an unrealistic scenario but did yield a conservative upper limit for the number of health effects $\left(10^{3}\right.$ to $\left.10^{5}\right)$ per $10^{4}$ years. The results of the well-water case matched the EPA proposed criteria of 10 health effects per $10^{4}$ years better than did the other four scenarios studied. The three river scenarios led to a very small number $\left(10^{-2}\right.$ to $\left.10^{1}\right)$ of health effects.

A review of the state-of-the-art of the AEGIS program was presented to the Waste Isolation Systems Panel of the National Academy of Sciences in September 1981. The panel suggested a study be made to determine the impact of adopting the new dose methodology recommended by the International Commission on Radiological Protection in their reports 26 and 30 . A preliminary evaluation performed for neptunium-237 indicated that the number of health effects calculated by the newer methodology would be about an order of magnitude higher than those estimated by the EPA for their proposed waste disposal standard. This study will be extended in FY 1982.

\section{SALT DOME RSIA}

Potential radiation doses for persons consuming contaminated table salt produced by solution mining of a salt dome repository had previously been calculated for periods of 100 years to 30,000 years after closure. During early FY 1981, these calculations were extended to include scenarios where the salt was first mined at $10^{5}$ and $10^{6}$ years after disposal of spent nuclear fuel in the salt dome. During the latter two periods, the radionuclide contributing the major share of the radiation dose was radium-226, which grows in as part of the uranium decay chain.

(a) Subtask agreement (Water and Land Resources Department). 



\title{
- Hanford Defense Waste Studies(a)
}

\author{
Principal Investigators: B. A. Napier and E. C. Watson
}

PNL is assisting DOE in preparation of a programmatic environmental documentation on the potential strategies for managing Hanford Defense nuclear waste. The Ecological Sciences Department is performing the subtasks of developing guidance on allowable amounts of residual environmental contamination and calculating potential public health and safety impacts from proposed operations.

\section{WASTE DISPOSAL GUIDANCE}

An important consideration in the disposal of radioactive waste and, consequently, in the preparation of the Hanford Defense Waste (HDW) environmental impact documentation, is the amount of radioactive contamination that may be allowed to remain in place at any given waste site. The allowable residual contamination level (ARCL) is dependent on the radiation dose limit imposed, the physical characteristics of the waste site, and the time at which exposure to the wastes is presumed to occur.

A method for generating an ARCL has been developed. The method uses the following steps:

- develop plausible Hanford-specif ic exposure scenarios

- calculate maximum annual radiation doses to an individual for each radionuclide based on the physical characteristics of the existing site and for the site-specific exposure scenario

- calculate the ARCL for all nuclides present in the mixture, uncorrected for cleanup or waste-migration barrier considerations. In addition to the ARCL based on dose rate considerations, an additional $A R C L$ is calculated based on the perception

(a) Subtask Agreement (Radiological Sciences Department). that some sites containing sizable quantities of transuranic radionuclides should be cleaned up regardless of postulated dose

- apply any corrections for addition of barriers to waste migration or uptake, or of proposed cleanup activity, to obtain the ARCL for the proposed action.

Numerical values for parameters used at Hanford have been developed, and the technique has been successfully applied to several hundred Hanford waste sites. Documentation of the method is in progress.

\section{HEALTH AND SAFETY IMPACTS}

Nearly 400 individual waste sites have been identified at Hanford. Any activities proposed for either geologic or in-situ dissal of these wastes will have some environmental impact. The objective of this task is to calculate radiation doses to occupationally exposed workers and members of the general public from activities associated with continuing present action, disposal of these wastes in situ, or disposal in onsite or offsite geologic repositories.

Hanford waste sites have been catagorized in terms of transuranic content, depth, source, location, and degree of containment. Estimates of atmospheric releases of radionuclides have been made for a range of activities. Occupational and public doses are being calculated for these activities. 


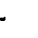




\title{
- Service Assessment Studies(a)
}

\author{
Principal Investigators: D. G. Watson, W. H. Rickard and R. E. Fitzner
}

Service Assessment Studies are supported through the DOE Richland Operations Office and are concerned with the long-term ecological monitoring of animal populations that may be affected by operations of the Hanford site. They provide data useful for the natural resource management of the middle Columbia River as well as for the estimation of the effects of operations at Hanford.

FALL CHINOOK SALMON SPAWNING NEAR HANFORD, 1980

Annual salmon spawning studies, begun in 1947 , were continued in 1980. Aerial surveys of the Columbia River were conducted from near the City of Richland, Washington, to Priest Rapids Dam (river km 542 to 637). The enumeration of salmon redds (nests) was generally hampered by poor weather during most of the spawning season, and the estimated number of redds is consequently below what would be expected under more suitable observation conditions.
Surveys were made on 0ctober 16 and 24 and on November 4 and 13,1980 . The total number of redds observed was 1487 , and the greatest numbers were observed on November 4 . The principal spawning areas were much the same as in previous years. The high river elevations that prevailed during the time (midday) of observations at the midway area (river $\mathrm{km} \mathrm{632)}$ made the counts at this location the most uncertain.

Estimates of fall chinook salmon spawning at Hanford are compared with adult fall chinook passage at McNary Dam, Ice Harbor Dam and Priest Rapids Dam during recent years (Table 1). Although the estimated number of fall chinook salmon spawning near Hanford in 1980

TABLE 1. Comparison of Estimated Fall Chinook Salmon Population with Adult Passage Over River Dams

\begin{tabular}{|c|c|c|c|c|c|}
\hline Year & $\begin{array}{l}\text { McNary Dam } \\
\text { (R.km 470) }\end{array}$ & $\begin{array}{l}\text { Ice Harbor Dam(a) } \\
\quad(\text { R.km } 522+16)\end{array}$ & $\begin{array}{c}\text { Hanford(b) } \\
\text { (R.km 570-632) }\end{array}$ & $\begin{array}{l}\text { Priest Rapids Dam } \\
\text { (R.km 637) }\end{array}$ & $\begin{array}{l}\text { Unaccounted for } \\
(\%)(\mathrm{c})\end{array}$ \\
\hline 1968 & 72,751 & $24,377(34)$ & 25,165 (35) & $22,165(30)$ & 1 \\
\hline 1969 & 79,375 & $17,507(22)$ & $31,556(40)$ & $16,042(20)$ & 18 \\
\hline 1970 & 61,554 & $10,385(17)$ & $26,691(43)$ & $19,884(32)$ & 8 \\
\hline 1971 & 69,718 & $11,004(16)$ & $25,200(36)$ & $12,345(18)$ & 30 \\
\hline 1972 & 49,307 & $9,436(19)$ & $6,132(12)(d)$ & $9,104(18)$ & 51 \\
\hline 1973 & 73,253 & $8,353(11)$ & $20,755(28)$ & 10,083 & 47 \\
\hline 1974 & 62,009 & $2,814(5)$ & $5,096(8)(d)$ & $7,619(12)$ & 75 \\
\hline 1975 & 68,719 & $2,558(4)$ & $18,781(27)$ & $13,366(19)$ & 50 \\
\hline 1976 & 87,991 & $1,474(2)$ & $13,657(16)$ & $10,774(12)$ & 71 \\
\hline 1977 & 84,370 & $1,756(2)$ & $22,680(27)$ & $6,856(8)$ & 63 \\
\hline 1978 & 44,145 & $1,609(4)$ & $21,196(48)$ & $6,541(15)$ & 33 \\
\hline 1979 & 49,961 & $2,074(4)$ & $20,881(42)$ & $7,727(15)$ & 39 \\
\hline 1980 & 38,910 & $1,744(4)$ & $10,409(27)$ & $8,442(22)$ & 47 \\
\hline
\end{tabular}

() Percent of McNary Dam count.

(a) Located in the Snake River, a major Columbia River tributary.

(b) Based on a redd to fish ratio of 1:7.

(c) Includes a small but undefined number of spawners ascending the Yakima and Walla Walla rivers.

(d) Redd estimates made under very poor observation conditions.

(a) Subtask Agreement (Richland Operations Office). 
was probably depressed due to poor survey conditions, this reach of the Columbia River remains a very important breeding area for fall chinook in the mid-Columbia River.

\section{BALD EAGLE STUDIES}

During the winter of 1980 (November 1980 to April 1981) intensive aerial surveys were conducted to collect data on waterfowl and bald eagle distribution and density. Twenty-four surveys were conducted and provide the most complete data set available to date on the Hanf ord eagles.

The intent of the 1980 winter survey was to gain a more complete record of distribution of eagles along the Hanford Reach. The highest count occurred on the morning of December 24 , when 26 eagles ( 15 juveniles and 11 aduits) were observed. That same afternoon, only 13 birds were counted. These temporal differences reflect the daily biological rhythms inherent in bald eagles. The eagles probably feed along the river in the morning and move inland to roosts in the afternoon. This illustrates that eagle surveys provide an index of annual abundance rather than a consistently accurate census. The data we present are valuable for examining changes in relative abundance and are most useful in evaluating the distribution of eagles within given segments of the river. Our data reveal that over $93 \%$ of all eagle sightings occurred above the Hanford powerline, and less than $5 \%$ occurred from Islands 12 through 20 (Figure 1).

\section{GOOSE NESTING STUDIES}

The annual goose nesting study for 1981 provides nesting records on 169 Canada goose nests on the Hanf ord Reach of the Columbia River. Productivity has been on the increase

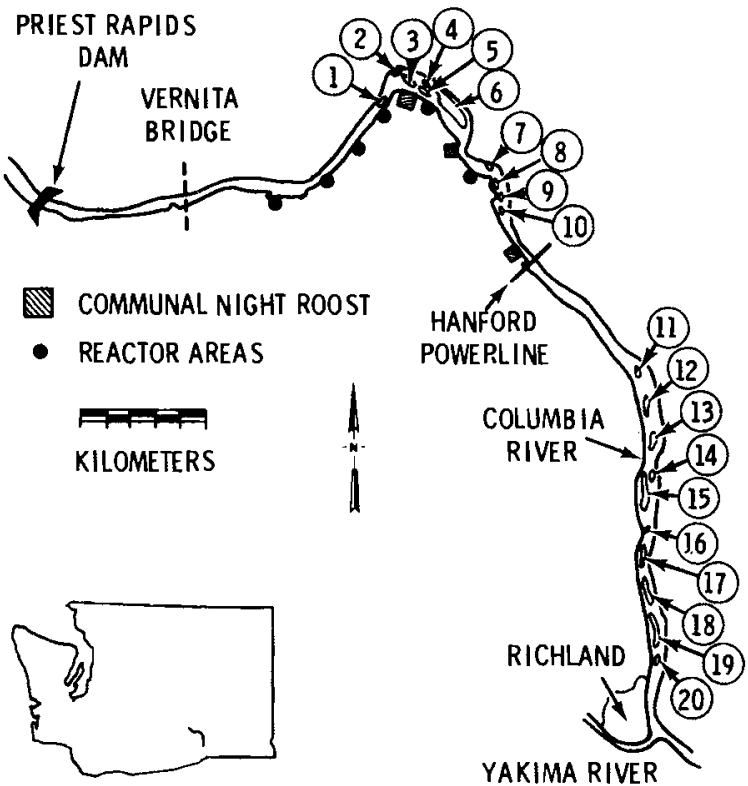

FIGURE 1. Locations of Eagle Night Roosts on the Hanford Site

since 1975, when a low of 108 nests were found. In 1968 and 1969, 170 and 163 nests, respectively, were recorded on the Hanford reach. Clearly, the goose population is on an upswing, perhaps due to coyote control measures under direction of the Washington Department of Game.

Of interest in 1981 were the location of four nests on cliffs, one in a deserted magpie nest, one in a Great Blue Heron nest and one on the 100-B reactor building. These findings point to the adaptability of Canada geese and provide yet another explanation for the increasing population level. 


\section{- Power Plant Fuel Conversion Environmental Impact Assessment(a)}

Principal Investigator: D. G. Watson

During FY 1981, Ecological Sciences Department staff participated in a Pacif ic Northwest Laboratory interdepartmental program to assist the DOE Economic Regulatory Administration prepare environmental impact assessments of the conversion of oil-burning electrical generating stations to coal or other alternate fuels. This program results from the implementation of the Fuel Use Act of 1978, designed to reduce the dependence on foreign energy sources through greater use of domestic fuels.
Draft environmental reports were prepared for the fuel conversion of four generating stations operated by the Baltimore Gas and Electric Company near Baitimore, Maryland, and for one generating station located near Sayreville, New Jersey, operated by Jersey Central Power and Light Company.

This program ended at the end of the fiscal year due to revision and reduction of $D O E$ programs by the new federal administration.

(a) Subtask Agreement (Energy Systems Department) . 



\title{
- Standardized Input for Hanford Environmental Impact Statements(a)
}

\author{
Principal Investigators: M. A. Mueller, J. D. Jamison and B. A. Napier
}

The DOE Waste Management Program has required that environmental impact statements (EIS) be prepared for a variety of waste management activities at the Hanford site. These EISs are prepared in accordance with the Council on Environmental Quality (CEQ) and DOE guidelines by several different lead contractors. The objective of this project, sponsored by the DOE Waste Management Program, is to reduce redundancy of effort and promote uniformity in EISs by preparing standardized sections and methods that are acceptable to DOE's Richland Operations Office and the Hanford contractors.

STANDARD HANFORD DOSE METHODOLOGIES

This task resulted in publication of a report describing current methods used at Hanford for calculating radiation doses to the public from

(a) Subtask Agreement (PNL) Waste Management Program Office). routine and accidental releases of radionuclides to the environment. It is intended as an overview of the available methods and as a starting point for persons preparing EISs for locations on the Hanford site. The report contains basic exposure scenarios, describes standard Hanford computer programs for dose calculations, and provides lists of Hanford Standard Pathway parameters to be used in performing the dose calculations. 
. 


\title{
- PUREX/Uranium Oxide Startup(a)
}

\author{
Principal Investigators: B. A. Napier and D. L. Strenge
}

Pacific Northwest Laboratory is assisting DOE prepare an environmental impact statement analyzing the effects of resuming operation of the plutonium and uranium extraction (PUREX) and uranium oxide $\left(\mathrm{UO}_{3}\right.$ ) chemical processing facilities at Hanford. The Ecological Sciences Department is supporting this effort with its expertise in modeling the environmental transport and fate of radionuclides.

The PUREX and $\mathrm{UO}_{3}$ facilities were used from 1936 to 1972 to process irradiated nuclear fuels and separate plutonium, uranium, and neptunium for use in defense and research and development programs. The Department of Energy is considering resuming operation of these facilities in April 1984. Normal operations result in routine releases of small quantities of radionuclides to the atmosphere and groundwater. Postulated abnormal events could release larger quantities of radioactive material. Radiation doses to members of the general public have been estimated

(a) Subtask Agreement (Radiological Sciences Department). for a variety of postulated circumstances. Chronic releases have been analyzed for three different processing rates, and five separate types of accidents have been examined. For routine operations, it has been found that the environmental consequences of the proposed action would comply with applicable guidelines and standards, and for abnormal events, there would be no adverse health effects to the public.

In addition to calculations for the proposed PUREX restart, a number of alternatives have been examined. These include calculation of doses from proposed new facilities and operations at off-site locations such as Savannah River. 
<smiles>C1CCC1</smiles> 


\section{- Review of Soil Contamination Guidance(a)}

Principal Investigators: J. K. Soldat, M. A. Mueller and W. E. Kennedy, Jr.

A review of existing and proposed radioactive soil contamination standards and guidance was conducted for United Nuclear Corporation (UNC), Office of Surplus Facilities Management. The more applicable standards were reviewed, evaluated and summarized. Information pertaining to soil contamination for both facility operation and facility decommissioning was obtained from a variety of sources. These sources included: The Code of Federal Regulations, U.S. NRC Regulatory Guides, the Federal Register, topical reports written by various government agencies, topical reports written by national laboratories, and publications from the American National Standards Institute (ANSI). Most of the information reviewed was consistent with the philosophy of maintaining exposures at levels "as low as reasonably achievable" (ALARA).

Sixteen information sources were found that pertain to government guidance and standards on soil contamination. Four of the standards that relate directly to acceptable soil contamination levels for unrestricted release of 1 and areas have been accepted by government agencies. Nine sources were found in which soil contamination 1 imits are used or recommended by sources other than government agencies.

No two standards or sets of guidance were based on the same criteria. For example, the number of radionuclides considered ranges from one, to several, to all radionuclides. Some limits specify concentration levels in the soil, others specify an acceptable dose or

(a) Intercontractor Work Agreement (UNC). dose rate from the soil. Since each standard reviewed is intended for a specific situation, and since different units are used for the standards, no attempt was made to arrive at a numerical range of acceptable values. Because of the wide differences that were found among the existing standards and guidance, we also conclude that it is difficult to directly apply existing soil contamination standards to circumstances other than those for which they were derived.

Most of the standards and guidance reviewed adopt the philosophy of maintaining radiation exposures "as low as reasonably achievable" (ALARA). In fact, the NRC, in its latest recommendations for decommissioning criteria, endorses the adoption of a range of acceptable annual doses between 1 and $10 \mathrm{mrem} / \mathrm{yr}$, based on ALARA. 



\title{
- Preliminary Radiation Dose Analysis for Reference FUSRAP Waste Sites
}

\author{
Principal Investigators: W. E. Kennedy, Jr. and R. L. Aaberg
}

The purpose of this study is to provide Bechtel National at Oak Ridge, Tennessee, with a preliminary radiation dose analysis of buried radioactive waste for the formerly utilized site remedial action program (FUSRAP). Bechtel National will use the preliminary results from this analysis to identify important scenarios, radionuclides, and exposure pathways for site-specific cost/benefit analyses. Formerly utilized sites include several sites at which uranium ores were processed. Many of the sites considered by FUSRAP have relatively large inventories of buried radioactive waste materials. The overall scope of FUSRAP is to determine the most cost effective remedial action plans for these sites.

Maximum annual radiation doses to a maximumexposed individual were calculated for four waste-migration scenarios. These scenarios were: over load flow through surface water, well water migration, ground water migration, and surface erosion. The doses were calculated for a reference site located in either a humid eastern or arid western environment. Two radionuclide inventories were considered.
The first included all of the radionuclides in uranium decay chain starting with uranium238, and the second assumed that the uranium isotopes had been removed leaving only radium226 and other daughter products. The preliminary calculations were designed to display the radionuclide migration and radiation dose models, and ident ify potentially important radionuclides and exposure pathways. 


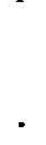




\section{- Environmental Assessment for Advanced Isotope Separation}

Principal Investigator: P. J. Mellinger

The goal of the DOE uranium enrichment program is to meet domestic, foreign, and U.S. government requirements for uranium enrichment services in the most economical, reliable, safe and environmentally acceptable manner possible.

The primary goal of the advanced isotope separation (AIS) program is to develop a uranium enrichment technology that will produce enriched uranium at a cost of less than $\$ 40$ per separative work unit (SWU) (end of FY 1981 dollars) in the mid 1990s.

There are three potential applications for an AIS process, all of which significantly lower the cost of uranium enrichment:

- Replace power intensive diffusion plants

- Supply additional separative work capacity as required for expansion of nuclear power.

- Economically lower the tails assay of the enrichment enterprise.

A generic environmental assessment is being prepared which is in compliance with National Environmental Policy Act (NEPA) regulations.

This document compares the environmental impacts of the three alternative AIS technolo- gies. The primary purpose of the environmental assessment is to provide the environmental impact perspective to the Process Evaluation Board (PEB) that will be responsible for recommending one of the AIS technologies for the demonstration phase of research and development.

A multidisciplinary task force composed of engineers, ecologists, health physicists, and social scientists was organized to conduct this work. Pacific Northwest Laboratory has involved the design engineers of Los Alamos National Laboratory, Lawrence Livermore $\mathrm{Na}-$ tional Laboratory, TRW Inc., and Union Carbide Corp., Nuclear Division (UCC-ND), in this effort.

During FY 1981, the social-impact sections of the full-scale facility were written. More information is needed to complete the generic environmental impact sections. The accident analysis and sections on occupational exposures are being drafted. 

Electric Field Research 


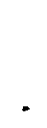




\section{ELECTRIC FIELD RESEARCH}

\section{- Biological Studies of a 1200-kV Prototype Transmission System}

This is an ongoing study for Bonneville Power Administration (BPA) an arm of DOE. The study, located at BPA's 1100-kV prototype line located near Lyons, Oregon, is the first research to monitor the effects of a transmission line of this voltage on a natural ecosystem. Standard BPA voltage is $500-\mathrm{kV}$. Specific studies include possible effects on wildlife, crops, honeybees, cattle, pasture grasses and trees. This work is demonstrating what can be expected if $1100-\mathrm{kV}$ lines are built in the Northwest and may also help BPA engineers find ways to construct those lines so that any effects observed in this study can be minimized. Details of this work are reported separately in the Annual Report for 1981 on Interagency/Contract Research, Ecological Sciences Department. 
. 
Energy-Related
Research for
Other Agencies 


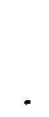




\section{ENERGY-RELATED RESEARCH FOR OTHER AGENCIES}

Argonne National Laboratory

Environmental Protection Agency

Knolls Atomic Power Laboratory

National Institute of Environmental and Health Sciences

National Oceanographic and Atmospheric Administration

National Science Foundation

Nuclear Regulatory Commission

Puget Sound Power \& Light Company/Northwest Energy Services Company

U.S. Fish and Wildlife Service (Department of the Interior)

The purpose of this section is to identify energy research tasks conducted for other sponsors cooperating with DOE. In these cases, interagency and other mutual agreements have been executed to support work on a nonduplicative basis. Research topics identified in this section are complementary to work discussed in other sections of this report, and the data bases being developed provide a unique long-term reference for environmental and energy assessment in arid western locations.

Federal agency research that was transferred to the Environmental Protection Agency in October $\mathbf{1 9 7 9}$ is listed for convenience in this section. A detailed progress report will be found in our Annual Report for 1981 on Interagency/Contract Research, Ecological Sciences Department. 


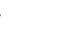




\section{ARGONNE NATIONAL LABORATORY}

Environmental Consequences of Postulated Pu Releases from Commercial Plutonium Fabrication Facilities as a Result of Severe Natural Phenomena (Principal Investigator: E. C. Watson)

\section{ENVIRONMENTAL PROTECTION AGENCY}

Acute Effects of New Coal Conversion Technologies on Aquatic Systems (Principal Investigator:

W. E. Fallon)

Fate and Effects of Toxic Substances on Marine Ecosystem Processors (Principal Investigator: W. H. Pearson)

Development of Quantitative Methods for Assessing the Impacts of Environmental Pollution (Principal Investigators: J. M. Thomas and L. L. Eberhardt)

Radiation Dose-Risk Estimates Associated with the Practice of Deep-Sea Disposal of Low-Level Nuclear Waste: Methods, Assumptions, and Information Needs (Principal Investigator: D. A. Baker)

\section{KNOLLS ATOMIC POWER LABORATORY}

Benthic Boundary Layer Program (Principal Investigator: C. I. Gibson)

\section{NATIONAL INSTITUTE OF ENVIRONMENTAL AND HEALTH SCIENCES}

Heavy Metal and Metal Complexes in Soils and Plants (Principal Investigator: R. E. Wildung)

\section{NATIONAL OCEANOGRAPHIC AND ATMOSPHERIC ADMINISTRATION}

Organic Pollutants in Waterways Adjacent to Commencement Bay (Principal Investigator: R. G. Riley)

Effects of Experimental Contamination with Prudhoe Bay Crude Oil on Faunal Recovery in the Strait of Juan de Fuca (Principal Investigator:

J. R. Vanderhorst)
The Effects of Oil-Contaminated Sediment on the Behavior of Sandworms, Nereis succinea and $N$. virens, and the Soft-Shell Clam, Mya arenaria (Principal Investigator: W. H. Pearson)

Dosing of Oysters with Stable and Radioactive Cadmium (Principal Investigator: J. T. Hardy)

Determination of the Biological Availability/Absorption of Cadmium (Principal Investigator: J. T. Hardy)

Analysis of Volatile Hydrocarbon Content of Marine Environment Sediment Reference Material in Support of NOAA/NMFS Research (Principal Investigator: R. G. Riley)

Estimation of Effects of Residual No. 2 Fuel Oils on Intertidal Infaunal Recovery Rate (Principal Investigator: J. R. Vanderhorst)

Effects of Single or Multiple Pollutants on Benthic Organisms (Principal Investigator: J. W. Anderson)

\section{NATIONAL SCIENCE FOUNDATION}

Immediate Effects of Mt. St. Helens Ash Fallout on Streams Draining Mt. Adams (Principal Investigator: C. E. Cushing)

\section{NUCLEAR REGULATORY COMMISSION}

Biocide By-Products in Aquatic Environments (Principal Investigator: R. M. Bean)

Environmental Standard Review Plans (Principal Investigator: D. G. Watson)

Application of Fisheries Management Techniques to Assessing Impacts (Principal Investigator:

D. H. McKenzie)

Quantitative Assessment of Aquatic Impacts of Power Plants (Principal Investigator: D. G. Watson)

Evaluation of Emergency Preparedness at NMSSLicensed Facilities (Principal Investigator:

J. D. Jamison) 
Relevance of Biotic Pathways to the Regulation of Nuclear Waste Disposal (Principal Investigator: D. H. McKenzie)

Technical Assistance for Commercial Power Reactor Dose Assessment, 1978 (Principal Investigator: D. A. Baker)

Removable Surface Contamination Level Analysis for Nuclear Materials Transportation Packages (CLAT) (Principal Investigator: E. C. Watson)

\section{PUGET SOUND POWER \& LIGHT COMPANY/ NORTHWEST ENERGY SERVICES COMPANY}

Environmental Studies for Licensing of InvestorOwned Twin Nuclear Generating Facility (Principal Investigators: T. L. Page, W. F. Sandusky, W. H. Walters, L. E. Rogers, J. M. Deesburg and A. E. Reisenauer)

\section{U. S. FISH \& WILDLIFE SERVICE}

Analytical Support for Studies of Effects of Oil Production in Northwest Wyoming on Aquatic Organisms (Principal Investigator: R. G. Riley)

Review and Analysis of 316(b) Demonstration Studies for the J. P. Pullman Power Plant Intake and Discharge Structure (Principal Investigator:

D. H. McKenzie)

Procedure for Developing Biological Input for the Design, Location or Modification of Water Structures and Prediction of Entrainment and Impingement (Principal Investigator: D. H. McKenzie) 


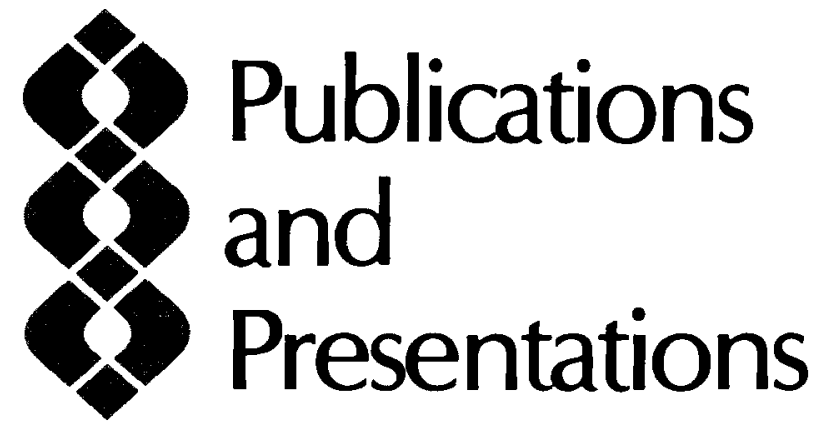




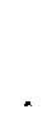




\section{PUBLICATIONS}

Allen, J. N. 1980. "The Ecology and Behavior of the Long-Billed Curlew in Southeastern Washington." Wildl. Monogr. 73:67.

Ames, L. L. 1981. Hanford Basalt Flow Mineralogy. PNL-2847, Pacific Northwest Laboratory, Richland, Washington.

Ames, L. L., and M. E. McGarrah. 1981. Distribution Coefficient Determinations, $197 \overline{9}$ Annual Report. PNL-3146, Pac if ic Northwest Laboratory, Richland, Washington.

Barnes, M. G. 1981. Statistics and the Statistician in Nuclear Site Decontamination and Decommissioning: Lecture Notes for a FourDay Short Course. PNL-SA-9486, Pacific Northwest Laboratory, Richland, Washington.

Barnes, M. G. 1980. "The Use of Kriging for Estimating the Spatial Distribution of Radionuclides and Other Spatial Phenomena." Issue 13 of TRAN-STAT (Statistics for Environmental Studies), ed. R. 0. Gilbert. PNL-SA-9051, Pacific Northwest Laboratory, Richland, Washington.

Bean, R. M., C. D. Becker, J. R. Skalski, W. E. Fallon, A. J. Scott, K. Shiosaki and B. W. Wilson. 1981. "Aqueous Suspensions of Solvent Refined Coal Liquids: Effects of Preparation Procedure on Chemical Composition and Toxicity." In Coal Conversion and the Environment: Chemical, Biomedical and EcoTogical Considerations, ed. D. D. Mahlum, R. H. Gray and D. W. Felix. CONF-801039, National Technical Information Service, Springfield, Virginia (in press).

Becker, C. D., and D. W. Crass. 1981. "Examination of Procedures for Acute Toxicity Tests with the Fathead Minnow and Coal Synfuel Blends." Arch. Environ. Contam. and Toxicol. (in press).

Becker, C. D., D. H. Fickeisen and J. C. Montgomery. 1981. As sessment of Impacts from Water Level Fluctuations on Fish in the Hanford Reach, Columbia River. PNL-3813, Pacific Northwest Laboratory, Richland, Washington.

Burton, F. G., D. A. Cataldo, J. F. Cline and W. E. Skiens. 1981. "Application of Controlled Release Technology to Uranium Mill Tailings Stabilization." In The State of Waste Isolation in the U.S. and Elsewhere, Advocacy Programs and Public Communications. Vol. 2 of Waste Management 1981, ANS Topical Meeting, ed. R. G. Post. Univ. of Arizona, Tuc son, Arizona.
Cadwe 11, L. L., R. G. Schreckhise, K. R. Price and F. P. Brauer. 1981. "The Persistence and Distribution of Iodine-129 in Surface Soil, Vegetation and Deer Tissues Near Hanford, Washington." In Abstracts of the 26th Annual Meeting of HeaTth Physics Society, Pergamon Press, New York.

Cataldo, D. A., T. R. Garland and R. E. Wildung. 1981. "Foliar Retention and Leachability of submicron Plutonium and Americium Particles." J. Environ. Qual., 10:31-37.

Cline, J.F. 1981. "Aging Effects of the Availability of Strontium and Cesium to Plants." Health Phys., 41:293-296.

Cline, J. F., D. A. Cataldo, W. E. Skiens and F. G. Burton. 1981. "Biobarriers Used in Shallow-Burial Ground Stabilization." Nucl. Technol. (in press).

Cline, J. F., W. H. Rickard and M. E. Thiede. 1981. "Growth of Barley Exposed to Solvent Ref ined Coal (SRC)." In Coal Conversion and the Environment: Chemical, Biomedical and Ecological Considerations, ed. D. D. Mahlum, R. H. Gray and D. W. Felix. CONF-801039, National Technical Information Service, Springfield, Virginia (in press).

Crecelius, E. A. 1981. "Prediction of Marine Atmospheric Depositon Rates Using $7 \mathrm{Be}$ Depositon Velocities." Atmos. Environ. 15:579-582.

Crecelius, E. A., J. M. Gurtisen and C. W. Apts. 1981. "Biological Uptake and Chemical Speciation of Copper in Seawater Determined by Electrochemistry." In Environmental Speciation and Monitoring Needs for Trace Metals Containing Substances from Energy-Related Processes. NBS Special Publication 618, ed. F. E. Brinckman and R. H. Fish. Government Printing Office, Washington, D.C.

Cushing, C. E., and J. M. Thomas. 1980. "Cu and $Z n$ Kinet ics in Myriophyllum heterophyllum Michx and Potamogeton richardsoni i (Ar. Benn.) Rydb." Ecology 61:1321-1326.

Cushing, C. E., D. G. Watson, A. J. Scott and J. M. Gurtisen. 1981. "Decrease of Radionuclides in Columbia River Biota Following Closure of the Hanford Reactor." Health Phys. $41: 59-67$

Cushing, C. E., and E. G. Wolf. 1981. "Organic Energy Budget of Rattlesnake Springs, Washington." Am. Midland Nat. (in press). 
Dauble, D. D., W. E. Fallon, R. H. Gray and R. M. Bean. 1981. "Potential Ecological Effects of a Coal Liquid from the Solvent Refined Coal II Process to Aquatic Organisms. In Abstracts of the American Fisheries Society, Western Division Meetings, American Fisheries Society, Bethesda, Maryland (in press).

Dauble, D. D., E. W. Lusty, W. E. Fallon and R. H. Gray. 1981. "Mixing and Separation Device for Continuous Flow Bioassays with Coal Liquids." Bull. Environ. Contam. and Toxicol. 26:717-723.

Drucker, H., and R. H. Gray. 1980. Solvent Refined Coal (SRC)-I I Detailed Environmental Plan. PNL-3517, Pac if ic Northwest Laboratory, $\overline{\mathrm{Rich}} \mathrm{l}$ and, Washington.

Dunigan, P. F. X., W. Lei and W. H. Rickard. 1980. "Pocket Mouse Population Response to Winter Precipitation and Drought." Northwest Sci. 54:289-295.

Eberhardt, L. L. 1981. "Review: Conservation and Management of Whales." Trans. Amer. Fish. Soc. (in press).

Eberhardt, L. L., and R. 0. Gilbert. 1980. "Statistics and Sampling in Transuranic Studies." In Transuranic Elements in the Environment, ed. W. C. Hanson, pp. 173-186. DOE/ TIC-22800, National Technical Information Service, Springfield, Virginia.

Eberhardt, L. L., A. K. Majorowicz and J. A. Wilcox. 1980. "Apparent Rates of Increase for Some Wild Horse Herds." J. Wildl. Manage. (in press).

Emery, R. M., D. C. Klopfer, D. A. Baker and J. K. Soldat. 1981. "Potential Radiation Dose from Eating Fish Exposed to Actinide Cont amination." Health Phys. 40:493-510.

Emery, R. M., D. C. Klopfer and M. C. McShane. 1980. "The Migration of Plutonium from a Freshwater Ecosystem at Hanford." In Transuranic Elements in the Environment, ed. W. C. Hanson, pp. 625-643. D0E/TIC-22800, $\mathrm{Na}-$ tional Technical Information Service, Springfield, Virginia.

Emery, R. M., D. C. Klopfer and J. R. Skalski. 1981. The Incipient Toxicity of Lithium to Freshwater Organisms Representing a Salmonid Habitat. PNL-3640, Pacific Northwest Laboratory, Richland, Washington.

Fickeisen, D. H., C. D. Becker and D. A. Neitzel. 1981. Review of Pacific Northwest Laboratory Research on Aquat ic Effects of $\mathrm{Hy}$ - droelectric Generation and Assessment of Research Needs. PNL-3816, Pac if ic Northwest Laboratory, Richland, Washington.

Fitzner, R. E. 1980. Behavioral Ecology of the Swainson's Hawk (Buteo swainsoni) in Washington. PNL-2754, Pacific Northwest Laboratory, Richland, Washington.

Fitzner, R. E., W. H. Rickard, L. L. Cadwell and L. E. Rogers. 1981. Raptors of the Hanford Site and Nearby Areas of Southcentral Washington. PNL-3212, Pac if ic Northwest Laboratory, Richland, Washington.

Fitzner, R. E., E. T. Sipco and R. G. Schreckhise. 1980. "American Coot Nesting and Feeding Habits in Southeastern Washington. Northwest Scj. 54:244-252.

Fitzner, R. E., D. G. Watson and W. H. Rickard. 1981. "Bald Eagles of the Hanford NERP." In Proceedings of the Washington Bald Eagles Symposium, ed. R. L. Knight, G. T. AlTen, M. B. Stalmaster and C. W. Stervhen, pp. 207-218. U.S. Fish and Wildife Service.

Gano, K. A. 1981. "Mortality of the Harvester Ant (Pogonomyrmex owyheei) After Exposure to 137 Cs Gamma Radiation." Environ. Entomol. $10: 39-44$.

Garland, T. R., D. A. Cataldo and R. E. Wildung. 1981. "Absorption, Transport, and Chemical Fate of Plutonium in Soybean Plants." J. Agric. and Food Chem. 29:915-920.

Garrott, R. A., D. A. Garrott and W. C. Hanson. 1981. "Forty-Fourth Annual Breeding Bird Census. Inland Coastal Tundra." Am. Birds 35:94.

Gilbert, R. 0. 1980. The Role of the Statistician in the Decommissioning of the New Brunswick Laboratory and Other Nuc lear Facilities. PNL-SA-9132, Pacific Northwest Laboratory, Richland, washington.

Gilbert, R. 0., and R. R. Kinnison. 1981. "Statistical Methods of Estimating the Mean and Variance from Radionuclide Data Sets Containing Negative, Unreported, or Less-Than Values." Health Phys. 40:377-390.

Gilbert, R. 0., R. R. Kinnison and M. G. Barnes. 1981. "On the Application of ACceptance Sampling to the Decommissioning of Nuclear Facilities." In Environmetrics 81, Summaries of Conference Presentations, pp. 140-145. Society for Industrial and Applied Mathematics, Philadelphia, Pennsylvania. 
Hakonson, T. E., R. L. Watters and W. C. Hanson. 1981. "The Transport of Plutonium in Terrestriai Ecosystems." Health Phys. $40: 63-69$.

Hanson, W. C. 1980. "Transuranic Elements in Arctic Tundra Ecosystems." In Transuranic Elements in the Environment, ed. W. C. Hanson, pp. 441-458. DOE/TIC-22800, National Technical Information Service, Springfield, Virginia.

Hanson, W. C. (ed). 1980. Transuranic Elements in the Environment. DOE/TIC-22800, National Technical Information Service, Springfield, Virginia.

Hanson, W. C. 1981. "Caribou (Rangifer tarandus) Encounters with Pipelines in Northern Alaska." Can. Field-Nat. 95:57-62.

Hanson, W. C., and D. R. Elle. 1980. "Radiological Assessments, Environmental Monitoring, and Study Design." In Transuranic Elements in the Environment, ed. W. C. Hanson, pp. 45-52. DOE/TIC-22800, National Technical Information Service, Springfield, Virginia.

Hanson, W. C., and J. M. Thomas. 1981. "Prediction of Strontium-90 Body burdens and Radiation Doses in Anaktuvuk Pass, Alaskan Eskimos Due to Fallout." Health Phys. (in press).

Hardy, J. T., C. W. Apts and S. P. Joyce. 1980. "Cadmium Bioaccumulation Kinetics in the Littleneck Clam, Protothaca staminea." Limnol. Ocean. (abstract, in press).

Hardy, J. T., R. L. Schmidt and C. W. Apts. 1981. "Marine Sediment and Interstitial Water: Effects on Bioavailability of Cadmium to Gills of the Clam Protothaca staminea." Bull. Environ. Contamin. Toxicol. (in press).

Hardy, J. T., and M. Valett. 1981. "Natural and Microcosm Phytoneuston Communities of Sequim Bay, Washington." Estuarine, Coastal and Shelf Sci. 12:3-12.

Hedlund, J. D., and W. H. Rickard. 1981. "Wildfire and the Short-Term Response of Small Mammals Inhabiting a Sagebrush-bunchgrass Community." The Murrelet 62:10-14.

Hedlund, J. D., and L. E. Rogers. 1980. "Great Basin Pocket Mice (Perognathus parvus) in the Vicinity of Radioactive Waste Management Areas." Northwest Sci. 54:153-159.

Hohenberger, C. J., D. P. Rudholm and W. C. Hanson. 1981. "Forty-Fourth Breeding Bird Census. Wet Coastal Plain Tundra." Am. Birds $35: 95$.
Jenne, E. A. 1981. "Speciation of Aqueous Contaminants--the Role of the Geochemical Model." In Proceedings of National Bureau of Standards Workshop on Aqueous Speciation of Dissolved Contaminants. NBS Special PubTication 618, ed. F. E. Brinckman and R. H. Fish. Government Printing office, Washington, D.C.

Kinnison, R. R. 1981. "Extreme Value Statistics Applied to Environmental Radionuclide Studies." Issue 14 of TRAN-STAT (Statistics for Environmental Studies), ed. R. 0. Gilbert. PNL-SA-9451, Pacific Northwest Laboratory, Richland, Washington.

Kinnison, R. R. 1981. "Extreme Value Statistics Applied to Environmental Radionuclide Studies." Issue 15 of TRAN-STAT (Statist ics for Environmental Studies), ed. R. 0. Gilbert. PNL-SA-9619, Pacific Northwest Laboratory, Richland, Washington.

Kinnison, R. R. 1981. "Extreme Value Statistics Applied to Environmental Radionuclide Studies." Issue 16 of (TRAN-STAT Statistics for Environmental Studies), ed. R. 0. Gilbert. PNL-SA-9847, Pac if ic Northwest Laboratory, Richland, Washington.

Laul, J. C., E. A. Lepel, W. C. Weimer and N. A. Wogman. 1981. "Precise Trace Rare Earth Analysis by Radiochemical Neutron Activation." J. Radioanal. Chem. (in press).

Laul, J. C., and W. C. Weimer. 1981. "Behavior of Rare Earth Elements in Geological and Biological Systems." In The Rare Earths in Modern Science and Technology, VoT. 3, ed. G. J. McCarthy, J. J. Rhyne and H. E. Silber. Plenum Press, New York (in press).

McShane, C. 1981. "Bluebunch Wheatgrass Productivity: The Effects of Burning and Clipping." Bul1. Ecol. Soc. Amer. 62:146 (abstract).

McShane, M. C. 1981. Bluebunch Wheatgrass Productivity: The Effects of Burning and Clipping. Thesis. Biological Sciences Department, Washington State University, Pullman, Washington.

Montgomery, J. C., D. H. Ficke isen and C. D. Becker. 1980. "Factors Influencing Smallmouth Bass Production in the Hanford Area, Columbia River." Northwest Sci. 54:296-305.

Mueller, M. A., W. E. Kennedy and J. K. Soldat. 1981. Review of Soil Contamination Guidance. PNL-3866, Pacific Northwest Laboratory, Richland, Washington. 
Napier, B. A. 1981. Standardized Input for Hanford Environmental Impact Statements, Part 1. PNL-3509, Pac if ic Northwest Laboratory, Richland, Washington.

Needler, G. T., and W. L. Templeton. 1981. "Radioactive Waste: The Need to Calculate an Oceanic Capacity." Oceanus 21:60-67.

Nieves, L. A., and M. H. Marti. 1981. Economic Feasibility Analysis of Water-Harvesting Techniques for Mine-Land Reclamation. PNL3737, Pac if ic Northwest Laboratory, Richland, Washington.

Penman, J. A., R. A. Garrott, A. Anthony, L. E. Eberhardt, H. Rothenbacher, G. L. Storm and W. M. Tzilkowski. 1981. "Bioindicators of the Health of Arctic Foxes." In Proceedings of the Worldwide Furbearer Conference, Vol. 1, ed. J. A. Chapman and D. Pursley, pp. 386-406. R. R. Donnelley and Sons, Falls Church, Virginia.

Price, K. R., R. 0. Gilbert and K. A. Gano. 1981. Americium-241 in Surface Soil Associated with the Hanford Site and Vicinity. PNL3731, Pacific Northwest Laboratory, Richland, Washington.

Rickard, W. H. and J. L. Warren. 1981. "Litterfall in Steppe Shrubs: Response to the 1977 Drought." Northwest Sc i. 55:108-112.

Rickard. W. H., and J. L. Warren. 1981. "Canopy Cover and Phytomass Comparisons of Steep Slopes Planted to Cheatgrass." Northwest Sci. 55:40-43.

Riley, R. G., T. R. Garland, K. Shiosaki, D. C. Mann and R. E. Wildung. 1981. "Alkylpyridines in Surface Waters, Groundwaters and Subsoils of a Drainage Located Adjacent to an 0il Shale Facility." Environ. Sci. Technol. 15:697-701.

Roesijadi, G. 1981. "The Significance of Low-Molecular-Weight Metallothionein-Like Proteins in Marine Invertebrates: Current Status." Mar. Environ. Res. 4:167-179.

Roesijadi, G. 1981. "Uptake and Incorporation of Mercury Into Mercury-Binding Proteins of Mytilus edulis as a Function of Time." Mar. Biol. (in press).

Roesijadi, G., and R. E. Hall. 1981. "Characterization of Mercury-Binding Proteins from the Gills of Marine Mussels Exposed to Mercury. Compar. Biochem. Physiol.

(in press).
Rogers, L. E., and K. A. Gano. 1980. "Townsend Ground Squirrel Diets in the Shrub-Steppe of South Central Washington." J. Range Manage. 33:463-465.

Rogers, J. E., S. W. Li and V. M. McNair. 1981. "Transport of Technetium by Trichoderma-380 Preincubated in Sulfur-Free Media." In Abstract of Annual Meeting of the American Society for Microbiology. American Society for Microbiology, Washington, D.C.

Salter, P. F., L. L. Ames and J. E. McGarrah. 1981. "Sorption of U, Tc and Se onto Basalt Under Ambient Repository Conditions." In EOS, Transactions to the American Geophysical Union 62:V207.

Sauer, R. H., and P. J. Hớ. 1981. Measuring Soil Water Content Using Gypsum BTocks with Long Leads. PNL-3618, Pac if ic Northwest Laboratory, Richland, Washington.

Schneider, M. J., S. A. Barraclough, R. G. Genoway and M. L. Wolford. 1980. "Effects of Phenol on Predation of Juvenile Rainbow Trout, Salmo gairdneri." J. Environ. Poll. $23: 121-130$.

Schneider, M. J., T. J. Conners, R. G. Genoway and S. A. Barraclough. 1981. "Some Effects of Simultaneous Thermal and Exercise Stress in Rainbow Trout (Salmo gairdneri)." Science $55: 62-69$.

Schreckhise, R. G., and J. F. Cline. 1980. "Comparative Uptake and Distribution of Plutonium, Americium, Curium and Neptunium in Four Plant Species." Health Phys. 38:817-824.

Schreckhise, R. G., and J. F. Cline. 1980. "Comparative Uptake and Distribution of Plutonium, Americium, Curium and Neptunium in Four Plant Species. In Transuranic Elements in the Environment, ed. W. C. Hanson, pp. 361-370. DOE/TIC-22800, National Technical Information Service, Springfield, Virginia.

Simpson, J. C., and R. 0. Gilbert. 1980. Estimates of Plutonium-239,240 and Americium241, Inventory, Spatial Pattern, and Soil Tonnage for Removal at Nuc lear Site 201, NTS. PNL-SA-8269, Pac if ic Northwest Laboratory, Richland, Washington.

Simpson, J. C., and R. 0. Gilbert. 1981. "The Use of Kriging to Estimate Spatial Patterns and Inventories of Environmental Contaminants." In Environmentrics 81, Summaries of Conference Presentations pp. 78-79. Soc $i-$ ety for Industrial and AppTied Mathematics, Philadelphia, Pennsylvania. 
Skalski, J. R., M. C. McShane and W. T. Hinds. 1981. "A Statistical Evaluation of Litterfall Data from a Forest Monitoring Study." In Environmetrics 81, Summaries of Conference Presentations, pp. 188-189. Society for Industrial and Applied Mathematics, Philadelphia, Pennsylvania.

Soldat, J. K., J. P. Corley, R. L. Kathren and D. L. Strenge. 1981. "Radiation Doses from Mount St. Helens 18 May 1980 Eruption." Technical Note 213:585.

States, J. B., S. A. Barraclough, D. D. Dauble, W. E. Fallon, J. R. Skalski and R. H. Gray. 1980. "Comparative Toxicity of a Coal Liquid and Two Reference 0 il Water Soluble Fractions to a Freshwater Intertebrate." In Coal Conversion and the Environment: Chemical, Biomedical and Ecological Considerations, ed. D. D. Mahlum, R. H. Gray and D. W. FeTix. CONF-801039, National Technical Information Service, Springfield, Virginia.

Strenge, D. L. 1981. "A Simplified Evacuation Model for Estimating Mitigation of Early Population Exposures." Irans. Am. Nuc 1. Soc. 38:95-96.

Strenge, D. L., and R. A. Peloquin. 1981. HADOC--A Computer Code for Calculation of EXternal and Inhalation Doses from Acute Radionuc lide Releases. PNL-3503, Pacific Northwest Laboratory, Richland, Washington.

Strenge, D. L., and R. A. Peloquin. 1981. PEDIC-A Computer Program to Est imate the Effect of Evacuation on Population Exposure Following Acute Radionuclide Releases to the Atmosphere. PNL-3634, Pacific Northwest Laboratory, Richland, Washington.

Templeton, W. L. 1981. "Dumping of LowLevel Radioactive Waste in the Deep Ocean." In Impacts of Radionuc lide Releases into the Marine Environment. IAEA-SM-2481150, International Atomic Energy Agency, Vienna. pp. 451-464.

Templeton, W. L. 1981. "Management of Dumping of Packaged Low-Level Radioactive Wastes in the Deep Ocean with Emphasis on the Northeast Atlantic Dump Site." Nucl. Eng. Int. (in press).

Templeton, W. L. 1981. "Radiological Basis for the Dumping of Low-Level Packaged Waste in the Deep ocean." Rapp. Comm. Int. Mer. Medit. 27:117-119.
Thomas, J. M., and L. L. Eberhardt. 1980. "Can Results From Animal Studies Be Used to Estimate Dose or Low Dose Effects in Humansu" In Third International Radiopharmaceutical Dosimetry Symposium, ed. E. E. Watson, A. T. Schlafke-Stelson, J. L. Coffey, R. J. Cloutier, pp. 259-282. FDA 81-8166, U.S. Dept. of Health a Human Services, Rockville, Maryland.

Thomas, J. M., and L. L. Eberhardt. 1981. "An Extrapolation of Radionuclide Retention Data from Mouse to Man." Health Phys. $40: 485-492$.

Thomas, J. M., W. T. Hinds, M. C. McShane, J. R. Skalski and M. I. Cochran. 1981. "Monitoring Forest Litterfall for Nutrient, Trace and Heavy Metals." In Proceedings of Environmetrics 81, Summaries of Conference Presentations April 8-10, 1981, Washington, D.C. pp. 186-187. Environmental Protection Agency, Washington, D.C.

Vaughan, B. E., et al. 1981. Pacific Northwest Laboratory Annual Report for 1980, Ecological Sciences. PNL-3700, PT2, Pacific Northwest Laboratory, Richland, Washington.

Vaughan, B. E., J. K. Soldat, R. G. Schreckhise, E. C. Watson and D. H. McKenzie. 1981. "Problems in Evaluating Radiation Dose Via Terrestrial and Aquatic Pathways." Environ. Health Persp. (in press).

White, G. C., and R. 0. Gilbert. 1981. Nonparametric Statistics to Analyze Transuranic Data. PNL-SA-9723, Pacific Northwest Labora$\overline{\text { tory, }}$ Richland, Washington.

White, G. C., J. C. Simpson and K. V. Bostick. 1980. Studies of Long-Term Ecological Effects to Uranium V. LA-8221, Los ATamos National Laboratory, Los Alamos, New Mexico.

Wildung, R. E., and T. R. Garland. 1980. "The Relationship of Microbial Process to the Fate and Behavior of Transuranic Elements in Soils, Plants, and Animals." In Transuranic Elements in the Environment, ed. W. C. Hanson, pp. 300-335. D0E/TIC-22800, National Technical Information Service, Springfield, Virginia.

J. S. Young, R. R. Adee, I. Piscopo and R. L. Buschbom. 1981. "Effects of Copper on the Sabellid Polychaete, Eudistylia vancouveri. II: Copper Accumulation and Tissue Injury in the Branchial Crown." Arch. Environ. Contamin. Toxicol. 10:87-104. 


\section{Manuscripts in Preparation}

Ames, L. L., J. E. McGarrah, B. A. Walker and P. F. Salter. 1981. "Sorption of Uranium and Cesium by Basalts and an Associated Secondary Smectite." Chem. Geol. (accepted).

Cushing, C. E., and R. T. Rader. 1981. "A Note on the Food of Callibaetis (Ephemeroptera: Baetidae)." Great Basin Nat. (submitted).

Dauble, D. D., W. E. Fallon, R. H. Gray and R. M. Bean. 1981. "Effects of Water-Soluble Fractions from a Fresh and a Water-Leached Coal Liquid on Growth and Survival of Four Aquatic Organisms." Arch. of Environ. Contam. Toxicol. (submitted).

Eberhardt, L. E., R. A. Garrott and W. C. Hanson. 1981. "Winter Movements of Arctic Foxes in a Petroleum Development Area." Can. Field-Nat. (submitted).

Eberhardt, L. E., W. C. Hanson and R. A. Garrott. 1981. "Den Use by Arctic Foxes in Northern Alaska." J. Mamm. (submitted).

Emery, R. E. 1981. "The Relevance of Ecological Theory to Environmental Hazards Assessments." Nature (submitted).

Emery, R. M., and T. M. Poston. 1981. "An Environmental Hazards Assessment of Ammonia in Freshwaters: Eight Scenarios." J. Water Pol1. Control Fed. (submitted).

Fitzner, R. E., W. H. Rickard and W. T Hinds. 1981. "Rejecta from Heron Colonies for Environmental Assessment of Toxic Elements." J. Environ. Monitor. Assess. (submitted).

Fitzner, R. E., and N. E. Woodley. 1981. "First Record of Carnus Hemapterus Nitzsch, as an Ectoparasite of the Swainson's Hawk." Raptor Res. (submitted).

Garland, T. R., R. E. Wildung and J. M. Zachara. 1981. "A Case Study of the Effects of 0 il Shale Operations on Water Quality. I: History of Operations and Hydrologic Controls." Environ. Sci. Technol. (submitted).

Gray, R. H., R. W. Hanf, D. D. Dauble and J. R. Skalski. 1981. "Chronic Effects of a Coal Liquid on a Freshwater Algae, Selenastrum capricornutum." Environ. Sci. Technol. (submitted).

Hanson, W. C. 1981. "Cesium-137 Concentrations in Northern Alaskan Eskimos, 19621979: Effects of Ecological, Cultural and Political Factors." Health Phys. (accepted).
Hinds, W. T. 1981. "Ecological Monitoring Design and Development." Science (submitted).

Hinds, W. T. 1981. "Production and Disappearance of Organic Matter in a Semi-Arid Annual Grassland." Ecology (submitted).

Hinds, W. T., M. C. McShane, J. R. Skalski and J. M. Thomas. 1981. "Using Litterfall for Quantitative Ecological Monitoring in Conifer Forests of the Pacif ic Northwest." Bu11. Ecol. Soc. Amer. (accepted).

Hohenberger, C. J., D. P. Rudholm and W. C. Hanson. 1981. "Wet Coastal Plain Tundra, Forty-Fifth Breeding Bird Census." Am. Bird (submitted).

MCCaffery, B. J., W. C. Hanson and R. 0. Burgess. 1981. "Inland Coastal Tundra, Forty-Fifth Breeding Bird Census." Am. Birds (submitted).

Poston, T. M., B. R. Parkhurst and J. R. Skalski. 1981. "A Collaborative Study of Acute Toxicity Tests Using Daphnia magna." Arch. Environ. Contam. Toxicol. (submitted).

Rickard, W. H. 1981. "Cation Content of Leaves of Desert Shrubs and Implications for an Improved Ecologic Classification." Am. Midland Nat. (submitted).

Rickard, W. H. 1981. "Climate and the Geographic Distribution of Desert Shrubs in South Central Washington and Southern Nevada." Northwest Sci. (submitted).

Rickard, W. H., J. F. Cline and D. W. Uresk. 1981. "Primary Production in Steppe Communities in South Central Washington." Ecology (submitted).

Rickard, W. H., and T. R. Garland. 1981. "Trace Element Content of Leaves of Desert Shrubs in South Central Washington." Northwest Sci. (accepted).

Rickard, W. H., and L. E. Rogers. 1981. "Wildfire in a Sagebrush-Bunchgrass Community: Short-Term Response of Biota." Ecology (submitted).

Rickard, W. H., D. W. Uresk and L. E. Rogers. 1981. "Controlled Cattle Grazing in a Sagebrush-Bunchgrass Community: A Four-Year Study." J. Range Manage. (submitted).

Roesijadi, G. 1981. "Influence of Mercaptoethanol on the Isolation of Mercury-Binding Proteins from the Gills of Mytilus edulis." Mar. Biol. (submitted). 
Roesijadi, G., A. S. Drum, J. T. Thomas and G. W. Fellingham. 1981. "Enhanced Mercury Tolerance in Marine Mussels and Relationship to Low-Molecular-Weight, Mercury-Binding Proteins." Mar. Pollut. Bull. (submitted).

Rogers, L. E., N. E. Woodley and J. K. Sheldon. 1981. "Food Habits of Darkling Beet les (Coleoptera tenebrionidae) Within a Shrub-Steppe Ecosystem." Am. Midland Nat. (submitted).

Sauer, R. H. 1981. "Reclaiming Mined Lands in Arid Environments." In Association of $\mathrm{Pa}-$ cif ic Coast Geographers Yearbook--1981. Oregon State University Press (submitted).
Skalski, J. R., and D. S. Robson. 1981. "A Mark and Removal, Field Procedure for Estimating Population Abundance. J. Wildl. Manage. (accepted).

Skalski, J. R., M. A. Simmons and D. S. Robson. 1981. "Comparative Census Procedures Using Single Mark-Recapture Methods." Ecology (submitted).

Young, J. S., and G. Roesijadi. 1981. "Reparatory Adaptation to Copper-Induced Injury and Occurrence of a Copper-Binding Protein in the Polychaete, Eudistylia vancouveri." Can. J. Fish. Aquatic Sci. (submitted). 
- 


\section{PRESENTATIONS}

surton, F. G., D. A. Cataldo, J. F. Cline and W. E. Skiens. 1981. "The Use of Controlled Release Herbicides in Waste Burial Sites." Presented at the Eighth International Symposium on Controlled Release of Bioactive Materials, July 26-29, 1981, Ft. Lauderdale, Florida.

Cadwe11, L. L., and R. E. Fitzner. 1981. "Regurgitated Pellets of Raptorial Birds as Indicators of Environmental Contamination." Presented at the Annual Meeting of the Northwest Section of the Wildlife Society, April 23-24, 1981, Coeur d'Alene, Idaho.

Crecelius, E. A. 1981. "The Significance of Atmospheric Input on Metal Concentrations in Oceanic Water and Suspended Matter." PNL-SA9134. Presented at the NATO Advanced Research Institute Symposium on Trace Metals in Sea Water. March 30-April 3, 1981, Erice, Sicily, Italy.

Eberhardt, L. E., and W. C. Hanson. 1981. "Arctic Fox Studies in the Vicinity of Prudhoe Bay." Presented at the Second Carnivore/ Furbearer Workshop, March 11-12, 1981, Fairbanks, Alaska.

Eberhardt, L. L., and W. C. Hanson. 1981. "Effects of $0 i 1$ Development on Arctic Foxes in Northern Alaska." Presented at the Pacific Northwest Bird and Mammal Soc iety Meeting, March 21-22, 1981, Richland, Washington, and at the Annual Meeting of the Northwest Section of the Wildlife Society, April 23-24, 1981, Coeur D'Alene, Idaho.

Hanson, W. C. 1981. "Impacts of 0 il Resource Developments on Tundra Bird Populations." Presented at the Annual Meeting of the Pacific Northwest Bird and Mammal Society--Inland Section, March 21-22, Richland, Washington, and at the Annual Meeting of the Northwest Section of the Wildlife Society, April 23-24, 1981, Coeur D'Alene, Idaho.

Hardy, J. T., C. W. Apts and S. P. Joyce. 1981. "Bioaccumulation of Nickel in the Littleneck Clam, Protothaca staminea." Presented at the International Conference on Heavy Metals in the Environment, September 15-18, 1981, Amsterdam.

Neitzel, D. A., D. H. Fickeisen and C. D. Becker. 1981. "Relative Tolerance of Four Intergravel Developmental Stages of Chinook Salmon to Dewatering." Presented at the 1981 Annual Meeting of the American Fisheries Society, September 16-18, 1981, Albuquerque, New Mexico.
Nieves, L. A., M. H. Marti and M. L. Warner. 1981. "An Economic Analysis of Unconventional Mined Land Reclamation in Arizona." Presented to the Western Social Sciences Association for Arid Lands Studies, April 23-25, 1981, San Diego, California.

Rickard, W. H. 1981. "Heat and Blast Effects of Nuclear Detonations on Desert Biota." Presented at the American Association for the Advancement of Science Symposium, June 16, 1981, Eugene, Oregon.

Rickard, W. H., and M. L. Warner. 1981. "Primary Productivity in Seral Climax Plant Communities in the Shrub-Steppe Region of Washington State, U.S.A." Presented at the XIII International Botanical Congress Meeting, August 21-28, 1981, Sydney, Australia.

Sauer, R. H., M. L. Warner and W. T. Hinds. 1981. "Ecological Characteristics Ident if ied from Algorithm Structure." Presented at the Northwest Science Associaton Annual Meeting, March 26-28, 1981, Corvallis, Oregon.

Strand, J. A., C. S. Abernethy, J. R. Skalski and R. G. Genoway. 1981. "Effects of Magnetic Field Exposure on Fertilization Success of Rainbow Trout, Salmo gairdneri." Presented at the Third Annual Meet ing of the Bioelectromagnetics Society, August 10-12, 1981 , Washington, D.C.

Strand, J. A., M. P. Fujihara, T. M. Poston and C. S. Abernethy. 1981. "Permanence of Suppression of the Primary Immune Response in Rainbow Trout, Salmo gairdneri, Sublethally Exposed to Tritiated Water During Embryogenesis." Presented at the Tritium Effects on Aquat ic Life Workshop, October 26-28, 1981, Chiba, Japan.

.Wildung, R. E., and J. M. Zachara. 1981. "Effects of 0 il Shale Solid Waste Disposal on Water Quality: Current Knowledge, Inf ormation Requirements, and Research Strategy." Presented at the Second Conference on $0 i 1$ Shale: The Environmental Challenges, August 10-13, 1981, Vail, Colorado. 


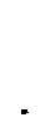




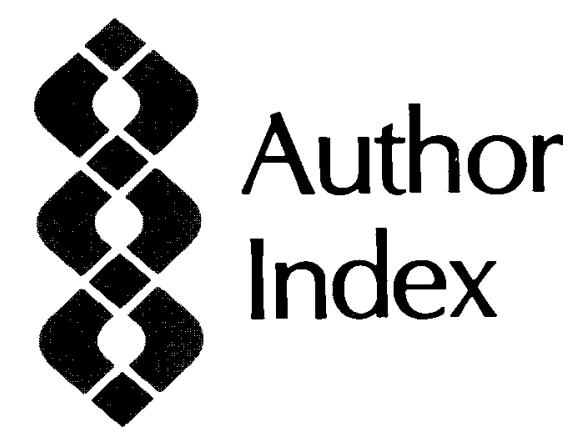





\section{AUTHOR INDEX}

Aaberg, R. L.; 159

Abel, K. H.; 81

Abernethy, C. S.; 129, 137

Ames, L. L.; 45

Bander, T. J.; 29

Bean, R. M.; 59

Becker, C. D.; 137

Beedlow, P. A.; 29

Burton, F. G.; 25

Cadwell, L. L.; 29, 91, 97

Cataldo, D. A.; 25, 45, 59, 77, 97

Cline, J. F.; 25, 89, 91

Crecelius, E. A.; 115

Daly, D. S.; 29

Dauble, D. D.; 59

Eberhardt, L. E.; 37, 91

Eberhardt, L. L.; 15

Emery, R. M.; 91

Fallon, W. E.; 59

Felice, L. J.; 59

Felmy, A.; 45

Fickeisen, D. H.; 137

Fitzner, R. E.; 11, 21, 149

Gano, K. A.; 11, 25, 91

Garland, T. R.; 45, 77, 97

Gee, G.; 45

Genoway, R. G.; 129

Gilbert, R. O.; 83
Hanson, W. C.; 37

Hardy, J. T.; 59, 109

Hinds, W. T.; 21, 91

Jamison, J. D.; 153

Jenne, E. A.; 45, 77

Kennedy, Jr, W. E.; 157, 159

Kinnison, R. R.; 83

Klopfer D. C.; 137

Kutt, J. C.; 85

Laul, J. C.; 85

Li, S. W.; 45, 97

Mayer, D. W.; 29

McFadden, K. M.; 45, 77, 97

McShane, M. C.; 11, 21, 29

Mellinger, P. J.; 59, 71, 161

Morris, J. E.; 105

Mueller, M. A.; 153, 157

Napier, B. A.; 145, 147, 153, 155

Neil, L. C.; 97

Neitzel, D. A.; 137

Nieves, L. A.; 19

Page, T. L.; 59

Poston, T. M.; 91, 125, 127

Rickard, W. H.; 1, 149

Riley, R. G.; 45

Robertson, D. E.; 81
Robson, D. S.; 17

Roesijadi, G.; 105

Rogers, L. E.; 11, 25, 91

Rogers, J. E.; 45, 59, 77, 97, 109

Sauer, R. H.; 11, 19

Schmidt, R. L.; 109

Schreckhise, R. G.; 77, 89, 91,97

Simmons, M. A.; 17

Simpson, J. C.; 83

Skaggs R. L.; 29

Skalski, J. R.; 17, 21, 29, 59, 129

Skiens, W. E.; 25

Soldat, J. K.; 145, 157

Strand, J. A.; 59, 125, 129

Strenge, D. L.; 155

Templeton, W. L.; 119

Thomas, J. M.; 21, 97

Trauger, G. M.; 17

Walters, W.; 29

Warner, M. L.; 19, 59

Warren, J. L.; 11

Watson, D. G.; 149, 151

Watson, E. C.; 147

Weimer, W. C.; 85

Wildung, R. E.; 45, 77, 97

Young, J. S.; 105

Zachara, J. M.; 45 


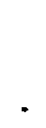




\section{Organization Charts Distribution}




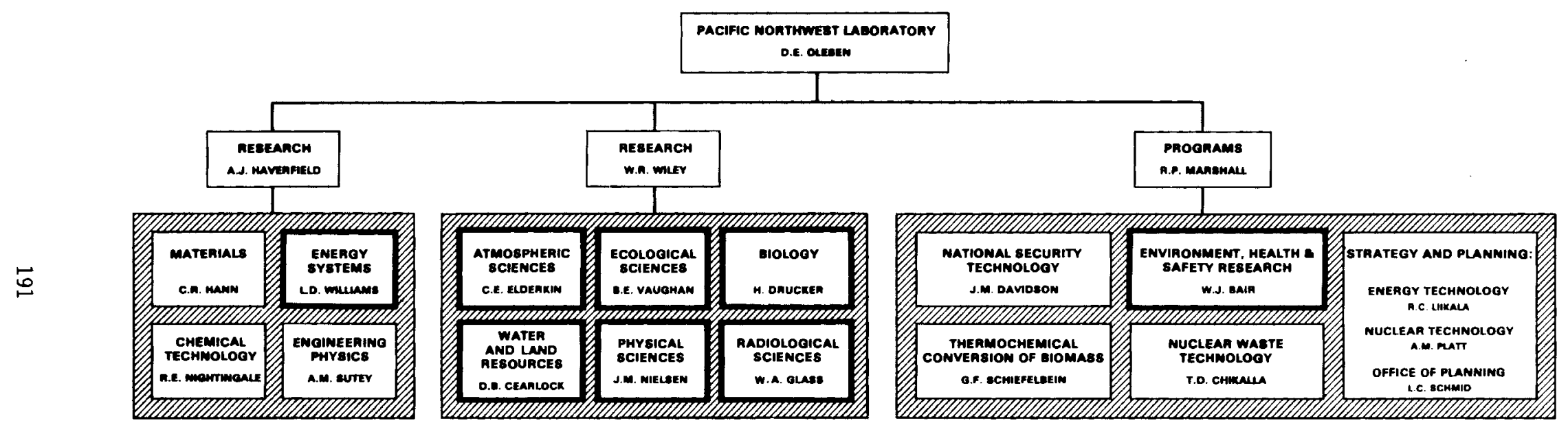

MOTE:

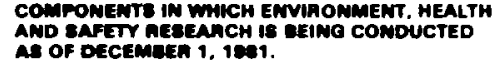




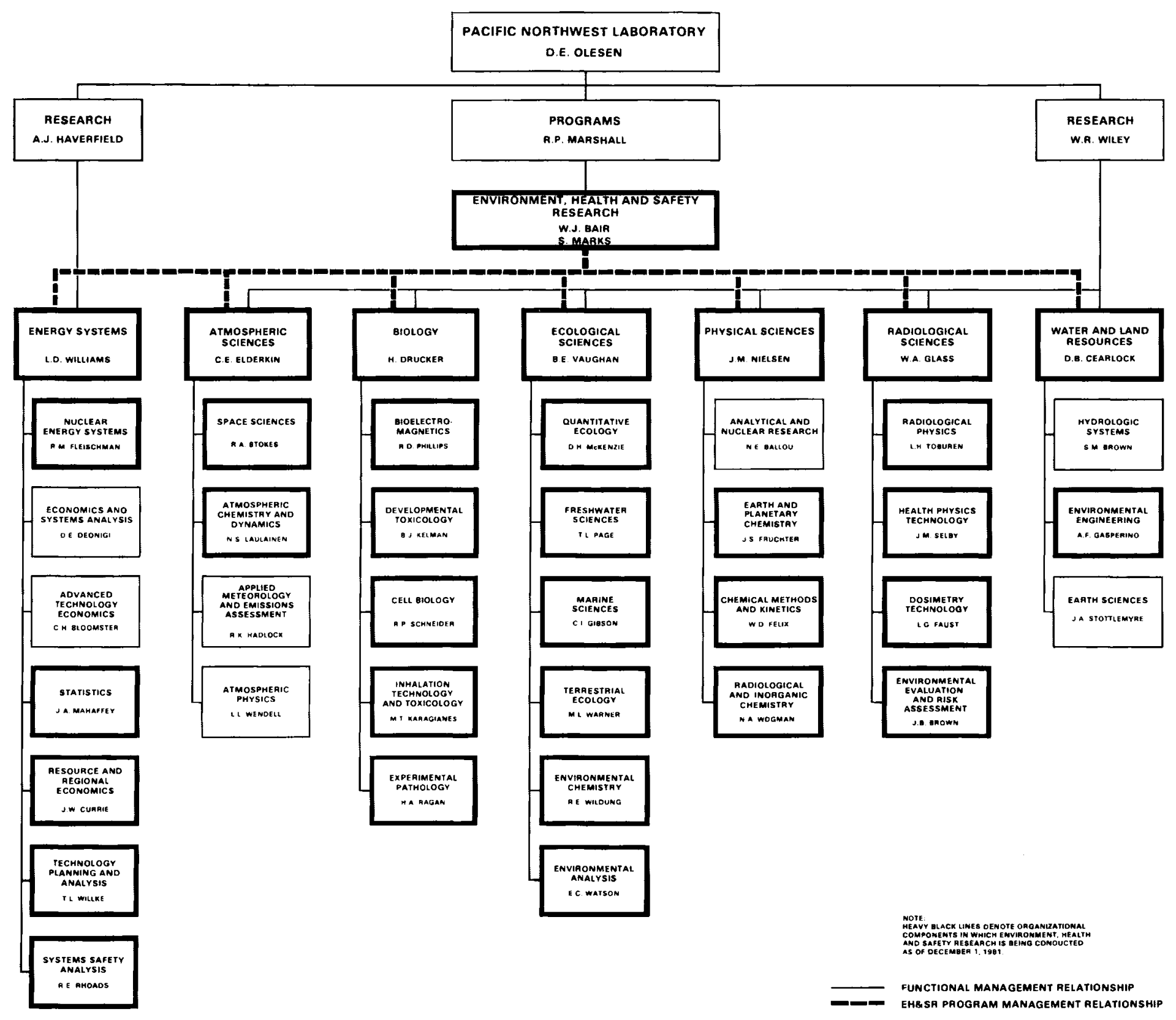




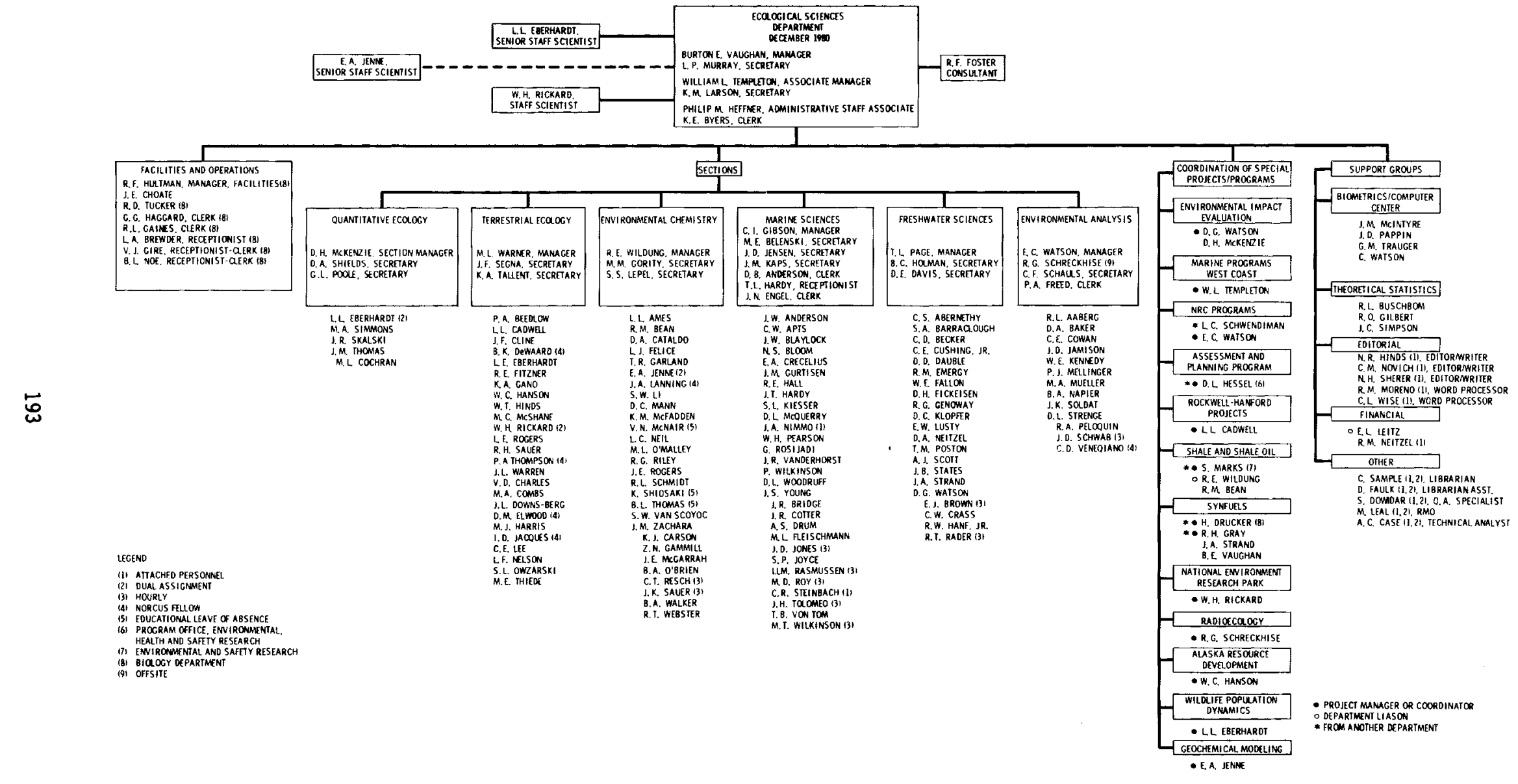




\section{OTHER CONTRIBUTORS}

\author{
Biology Department \\ Burton, F. G. \\ Morris, J. E. \\ Drucker, $\mathrm{H}$. \\ Energy Systems Department \\ Aaberg, R. L. \\ Gilbert, R. O. \\ Kinnison, R. R. \\ Marti, M. H. \\ Nieves, L. A. \\ Riedel, E. F. \\ Simpson, J. C. \\ Materials Department
}

Skeins, W. E.

Physical Sciences Department

Abel, K. H.

Kutt, J. C.

Laul, J. C.

Robertson, D. E.

Weimer, W. C.

Environmental, Health and

Safety Program Office

Gray, R. H.

Occupational \& Environmental

Protection Department

Bramson, P. E.

Price, K. R.
Rockwell Hanford Operations

Richland, WA

Salter, P. F.

Bedford Institute of

Oceanography

Dartmouth, NS (Canada)

Needler, G. T.

Lockheed Environmental Services

Carlsbad, CA

Schneider, M. J.

Arizona State University

Moser, R. J.

Nash, T. M.

Olafsen, A.

University of Alaska

Burgess, R. O.

Follman, $\mathrm{E}$.

Garrott, D. A.

Garrott, R. A.

Hohenberger, C. J.

McCaffery, B. J.

Penman, J. A.

Rudholm, D. P. 


\section{DISTRIBUTION}

No. of

Copies

Department of Energy

W. R. Albers

Environmental Protection

Safety and Emergency

Preparedness.

Department of Energy

Washington, DC 20545

J. S. Ball

Bartlesville Energy

Research Center

Department of Energy

P.0. Box 1398

Bartlesville, OK 74003

D. S. Ballant ine

Office of Energy Research

Department of Energy

Washington, DC 20545

R. Barber

Environmental Protection

Safety and Emergency

Preparedness

Department of Energy

Washington, DC 20545

J. R. Beall

Office of Energy Research

Department of Energy

Washington, DC 20545

E. W. Bean

Rocky Flats Area Office

Albuquerque Operations Office

P.0. Box 928

Golden, CO 80401

N. F. Barr

Office of Energy Research

Department of Energy

Washington, DC 20545

J. R. Blair

Office of Energy Research

Department of Energy

Washington, DC 20545

R. P. Blaunste in

Environmental Protection,

Safety and Emergency

Preparedness

Department of Energy

Washington, DC 20545
No. of

Copies

C. M. Borgstrom

Environmental Protection, Safety and Emergency

Preparedness

Department of Energy

Washington, DC 20545

A. A. Churm

DOE Chicago Patent

Attorney

9800 South Cass Avenue

Argonne, IL 60439

J. Coleman

Office of Energy Research

Department of Energy

Washington, DC 20545

R. W. Davies

Environmental Protection

Safety and Emergency

Preparedness

Department of Energy

Washington, DC 20545

L. J. Deal

Environmental Protection, Safety and Emergency

Preparedness

Department of Energy

Washington, DC 20545

A. W. Decora

Laramie Energy Research Center

Department of Energy

P.0. Box 3395

University Station

Laramie, WY 83071

T. J. Dobry

Office of Defense Programs

1000 Independence Avenue Department of Energy

Washington, DC 20545

J. Dorigan

Office of Energy Research

Department of Energy

Washington, DC 20545

A. P. Duhame 1

Office of Energy Research

Department of Energy

Washington, DC 20545
No. of

Copies

P. B. Dunaway

DOE - Nevada Operations Off ice

P.0. Box 14100

Las Vegas, NV 89114

F. Duncan

Office of the Assistant

Secretary for Nuc lear Energy

Department of Energy

Washington, DC 20545

C. W. Edington

Office of Energy Research

Department of Energy

Washington, DC 20545

B. M. Erickson

DOE - Schenectady Naval

Reactors office

P.0. Box 1069

Schenectady, NY 1230

G. C. Facer

Office of Defense

Programs

1000 Independence Ave., SW

Department of Energy

Washington, DC 20545

T. G. Frangos

Environmental Protection,

Safety and Emergency

Preparedness

Department of Energy

Washington, DC 20545

R. Franklin

Office of Energy Research

Department of Energy

Washington, DC 20545

D. M. Gardiner

DOE - Chicago Operations Office

9800 South Cass Avenue

Argonne, IL 60439

M. E. Gates

DOE - Nevada Operations Office

Department of Energy

P.0. Box 14100

Las Vegas, NV 89114 
No. of

Copies

M. Gottlieb

Environmental Protection, Safety and Emergency

Preparedness

Department of Energy

Washington, DC 20545

S. H. Greenleigh

Environmental Protection

Safety and Emergency

Preparedness

Department of Energy

Washington, DC 20545

G. H. Gronhovd

Grand Forks Energy

Research Center

Box 8213

University Station

Grand Forks, ND 58202

D. H. Hamilton, Jr. Office of Energy Research Department of Energy

Washington, DC 20545

E. Harvey

Office of Energy Research

Department of Energy

Washington, DC 20545

C. Heath

Environmental Protection

Safety and Emergency

Preparedness

Department of Energy

Washington, DC 20545

H. L. Hollister

Environmental Protection

Safety and Emergency

Preparedness

Department of Energy

Washington, DC 20545

B. House

Environmental Protection

Safety and Emergency Preparedness

Department of Energy

Washington, DC 20545

C. Jackson

DOE - San Francisco

Operations office

133 Broadway

Wells Fargo Building

Oakland, CA 94616
No. of

Copies

J. Kane

Off ice of Energy Research

Department of Energy

Washington, DC 20545

J. A. Lenhard

DOE - Oak Ridge

Operations office

P.0. Box E

Oak Ridge, TN 37830

W. J. Little, Jr.

Environmental Protection

Safety and Emergency

Preparedness

Department of Energy

Washington, DC 20545

J. N. Maddox

Office of Energy Research

Department of Energy

Washington, DC 20545

J. R. Maher

Environmental Protection, Safety and Emergency Preparedness

Department of Energy

Washington, DC 20545

D. D. Mayhew

Office of Energy Research

Department of Energy

Washington, DC 20545

6 H. McCammon

Office of Energy Research

Department of Energy

Washington, DC 20545

T. F. McCraw

Environmental Protection

Safety and Emergency

Preparedness

Department of Energy

Washington, DC 20545

M. L. Minthorn, Jr.

Office of Energy Research

Department of Energy

Washington, DC 20545

D. R. Monti

Environmental Protection, Safety and Emergency Preparedness

Department of Energy

Washington, DC 20545
No. of

Copies

\section{B. Morgan}

DOE - Savannah River

Operations Office

P.0. Box A

Aiken, SC 29801

W. E. Mott

Environmental Protection, Safety and Emergency

Preparedness

Department of Energy

Washington, DC 20545

W. A. Neustadt

Environmental Protection

Safety and Emergency

Preparedness

Department of Energy

Washington, DC 20545

W. S. Osburn, Jr.

Office of Energy Research

Department of Energy

Washington, DC 20545

C. Osterberg

Office of Energy Research

Department of Energy

Washington, DC 20545

W. H. Pennington

Division of NEPA Affairs

Department of Energy

Washington, DC 20545

A. F. Perge

Nuc lear Energy

Department of Energy

Washington, DC 20545

A. A. Pitrolo

Morgantown Energy

Research Center

Department of Energy

P.0. Box 880

Morgantown, WV 26505

R. Ray

DOE - Nevada Operations

Office

P.0. Box 14100

Las Vegas, NV 89114

W. Reese

DOE - Savannah River

Operations Office

P.0. Box A

Aiken, SC 29801 
No. of

Copies

J. R. Roeder

DOE - Albuquerque

Operations office

P.0. Box 5400

Albuquerque, NM 87115

D. M. Ross

Environmental Protection, Safety and Emergency

Preparedness

Department of Energy

Washington, DC 20545

R. D. Schull

Environmental Protection, Safety and Emergency Preparedness

Department of Energy

Washington, DC 20545

M. Schulman

Office of Energy Research

Department of Energy

Washington, DC 20545

D. H. Slade

Office of Energy Research

Department of Energy

Washington, DC 20545

J. H. Spickard

DOE - Idaho Operations Commission

550 Second Street

Idaho Falls, ID 8340

R. J. Stern

Environmental Protection, Safety and Emergency Preparedness

Department of Energy

Washington, DC 20545

J. F. Stevens

Dayton Area Office

DOE - Albuquerque Operations office

P.0. Box 66

Miamisburg, OH 45342

27 Technical Information Center

P.0. Box 62

Department of Energy

Oak Ridge, TN 37830

J. W. Thiessen

Office of Energy Research

Department of Energy

Washington, DC 20545
No. of

Copies

A. Trivelpiece

Office of Energy Research

Department of Energy

Washington, DC 20545

W. Vaughan

Environmental Protection

Safety and Emergency

Preparedness

Department of Energy

Washington, DC 20545

B. W. Wachholz

Environmental Protection

Safety and Emergency

Preparedness

Department of Energy

Washington, DC 20545

R. Waters

Office of Energy Research

Department of Energy

Washington, DC 20545

R. L. Watters

Office of Energy Research

Department of Energy

Washington, DC 20545

I. Wender

Pittsburgh Energy

Research Center

4800 Forbes Avenue

Pittsburgh, PA 15213

E. R. Williams

Environmental Protection, Safety and Emergency Preparedness

Department of Energy

Washington, DC 20545

M. M. Williamson

DOE - Idaho Operations Commission

550 Second Street

Idaho Falls, ID 83401

F. Wobber

Office of Energy Research

Department of Energy

Washington, DC 20545

R. W. Wood

Office of Energy Research

Department of Energy

Washington, DC 20545
No. of

Copies

Other Agencies and Institutions

R. E. Alexander Nuc lear Regulatory

Commission

Washington, DC 20545

E. L. Alpen

Lawrence Berkeley

Laboratory

University of California

Building 90, Room 2056

No. 1 Cyc lotron Road

Berkeley, CA 94720

S. I. Auerbach

Oak Ridge National

Laboratory

Oak Ridge Operations

Office

P.0. Box $X$

Oak Ridge, TN 37830

J. A. Auxier

Oak Ridge National

Laboratory

P.0. Box $X$

Oak Ridge, TN 37830

D. Beirman, Chief Document Service Branch

Central Intelligence

Agency

Attn: CRS/DPSD/DSB/IAS/ 409779/DB

Washington, DC 20505

V. P. Bond

Brookhaven National

Laboratory

Upton, Long I s land, NY

11973

Leo Bustad, Dean

College of Veterinary

Medicine

Washington State

University

Pullman, WA 99163

Chief

Game Management Division

Department of Game

600 North Capitol Way

Olympia, WA 98501

W. Cool

Nuc lear Regulatory

Commission

Washington, DC 20545 
No. of

Council on Environmental Quality

72 Jackson Place, N.W.

Washington, DC 20006

J. J. Davis

Assistant Director of Research

Nuc lear Regulatory Commission

Washington, DC 20545

Director

State Department of Ecology

Aquatic Pollution Control

Olympia, WA 98501

Director

New England Marine Laboratories

Washington Street

P.0. Box 1637

Duxbury, WA 02332

D. N. Edgington

University of Wisconsin

Center for Great Lakes

Studies

P.0. Box 413

Milwaukee, WI 53201

H. Ellett

Environmental Protection Agency

Washington, DC 20460

W. 0. Forster

Office of Energy Research

Department of Energy

Washington, DC 20545

J. R. Haugh

United States Geologic Survey

Anchorage, AK 99502

P. F. Hays

Nuc lear Regulatory

Commission

Washington, DC 20545

J. W. Healy

Los Alamos Scientific

Laboratory

University of California

P.0. Box 1663

Los Alamos, NM 97545
No. of

Copies

R. M. Jefferson

Sandia Laboratories

P.0. Box 5800

Albuquerque, NM 87187

J. F. Johnson

Kenworth Trucking

P.0. Box 1000

Kirkland, WA 98033

Librarian

Battelle Memorial

Institute

Columbus Laboratories

$505 \mathrm{King}$ Avenue

Columbus, $\mathrm{OH} 53201$

Librarian

Joint Center for Graduate Study

100 Sprout Road

Richland, WA 99352

Librarian

Research Library, Reference

Brookhaven National Laboratory

Upton, Long Island, NY 11973

Librarian

Lawrence Radiation Laboratory

University of California

Technical Information Dept., L-3

P.0. Box 808

Livermore, CA 94550

Librarian

Los Alamos Scientific Laboratory

P.0. Box 1663

Los Alamos, NM 87545

Librarian

Fisheries/0ceanography

University of Washington

Seattle, WA 98115

Librarian

Robert S. Kerr

Environmental Research Laboratory

Environmental Protection Agency, ORD

Ada, OK 74820
No. of

Copies

Librarian

Environmental Research Laboratory

Environmental Protection Agency, ORD

Athens, GA 30603

Librarian

Environmental Research Laboratory

Environmental Protection Agency, ORD

Corvallis, OR 97330

Librarian

Environmental Research Laboratory

Environmental Protection Agency, ORD

6201 Congdon Blvd.

Duluth, MN 55804

Librarian

Environmental Research Laboratory

Environmental Protection Agency, ORD

Gulf Breeze, FL 32561

Librarian

Environmental Research Laboratory

Environmental Protection Agency, ORD

Narragansett, RI 02882

Librarian

Northwest and Alaska Fisheries Center

National Marine Fisheries Service, NOAA

2725 Mont lake Blvd. East

Seattle, WA 98112

Librarian

Southeast Fisheries Center

National Marine Fisheries Service, NOAA

75 Virginian Beach Drive

Miami, FL 33149

Librarian

Northeast Fisheries Center

National Marine Fisheries Service, NOAA

Woods Hole, MA 02543 
No. of

Copies

Librarian

Southwest Fisheries

Center

National Marine Fisheries Service, NOAA

P.0. Box 271

La Jolla, CA 92038

R. Lunt

University of California

Center of Life Sciences

900 Veteran Avenue

West Los Angeles, CA 90024

J. W. McCaslin

INEL, Aerojet Nuc lear

550 Second Street

Idaho Falls, ID 83401

R. 0. McClellan

Inhalation Toxicology

Research Institute

Lovelace Foundation for Medical

Education and Research

P.0. Box 5890

Albuquerque, NM 87115

C. B. Meinhold

Brookhaven National

Laboratory

Upton, Long Is land, NY 11973

M. L. Mendelsohn

University of $\mathrm{California}$

Lawrence Livermore

Laboratory

P.0. Box 808

Livermore, CA 94550

W. R. Ney

Executive Director

National Council on Radiation Protection and Measurements

7910 Woodmont Avenue

Suite 1061

Washington, DC 20014

NRC Advisory Committee on Reactor Safeguards

Washington, DC 20545

D. F. Petersen

University of Southern California

Los Alamos Scientific Laboratory

P.0. Box 1663

Los Alamos, NM 87545
No. of

Copies

D. Rall, Director

NIEHS

P.0. Box 12233

Research Triangle Park, NC 27709

J. Z. Reynolds

Consumer Power Co.

212 W. Michigan Ave.

Jackson, MI 49201

R. E. Rol and

Argonne National

Laboratory

9700 South Cass Avenue

Argonne, IL 60439

R. A. Scarano

Nuclear Regulatory Commission

Mill Licensing Section

Washington, DC 20545

K. A. Smith

Sandia Laboratories

P.0. Box 5800

Albuquerque, NM 87187

F. Swanberg

Nuc lear Regulatory

Commission

Washington, DC 20545

A. Swartzman

Center for Quantitative Studies

University of Washington

Seattle, WA 98115

Technical Information Service

Room 773A

Savannah River Laboratory

E. I. du Pont de Nemours and $\mathrm{Co}$.

Aiken, SC 29801

G. L. Voelz

University of California

Los Alamos Scientif ic Laboratory

P.0. Box 1663

Los Alamos, NM 87545

H. L. Volchok

Department of Energy

Environmental Measures

Laboratory

376 Hudson Street

New York, NY 10014
No. of

Copies

W. W. Weyzen

Electric Power Research Institute

3412 Hillview Avenue

P.0. Box 10412

Palo Alto, CA 94303

R. E. Yoder

Rockwe 11 International

P.0. Box 464

Golden, CO 80401

\section{International}

Director,

Commonwealth Scientific and Industrial Research Organization

Aspenda?, Victoria

AUSTRALIA

Librarian

Australian AEC

Riverina Laboratory

P.0. Box 226,

Deniliquin, New South Wales

AUSTRALIA 2710

Librarian

Commonwealth Scientific and Industrial Research Organization

314 Albert Street

P.0. Box 89

East Melbourne, Victoria

AUSTRALIA

H. Daw, Director

Division of Health, Safety and Waste Management

International Atomic Energy Agency

Vienna 1, Kaerntnerring 11 AUSTRIA

L. Selini

Vienna International Center

P.0. Box 500

1400 Vienna

AUSTRIA 
No. of

Copies

A. M. Marko, Director

Atomic Energy of Canada Ltd.

Biology and Health Physics Division

Chalk River Nuc lear Laboratories

Chalk River, Ontario KOJ IJO CANADA

Library

M. Anderson

Department of National Health and Welfare

ottowa, Ontario

CANADA

Library

Pacific Environment Institute

Fisheries and Marine Services

Environment Canada

4160 Marine Drive

West Vancouver, B.C. V7V IN6 CANADA

\section{Librarian \\ Department of Fisheries and Oceans \\ Pacif ic Biological \\ Station \\ P.0. Drawer 100 \\ Nanaimo, British Columbia V9R $5 K 6$ \\ CANADA \\ Librarian \\ Department of Fisheries and Oceans \\ Fresh Water Institute \\ 501 University Crescent \\ Winnipeg, Manitoba R3T 2N6 \\ CANADA \\ Librarian \\ Atomic Energy of Canada Ltd. \\ Whiteshell Nuclear Research Establishment \\ Pinawa, Manitoba ROE $1 \mathrm{LO}$ CANADA}

M. J. Suess

Regional officer for

Environmental Hazards

World Heath Organization

8, Scherf igsvej

DK-2100 Copenhagen,

DENMARK
No. of

Copies

A. J. Dunster

National Radiological

Protection Board

Harwell, Diocot

Oxfordshire OXII ORQ

ENGLAND

Jayneth Parry Howells Central Electricity, Research Laboratories

Leatherhead, Surrey

ENGLAND

Librarian, Building 465

Atomic Energy Research Establi shment

Harwell, Diocot

Oxfordshire OXII ORQ,

ENGLAND

H. Smith

Biology Department

National Radiological Protection Board Building $565 \mathrm{~T}$

Harwell, Didcot

Oxfordshire OX110RQ

ENGLAND

F. D. Sowby

International Commission on Radiation Protection

Clifton Avenue

Sutton, Surrey

ENGLAND

Director

Commissariate a l'Energie Atomique

Centre d'Etudes

Nuc leaires de

Fontenay-aux-

Roses (Seine)

FRANCE

Librarian

Centre d'Etudes

Nucleaires de Saclay

P.0. Box 2, Saclay

Fig-sur-Yvette ( $\left.\begin{array}{ll}S & 0\end{array}\right)$

FRANCE

J. C. Nenot

Comite de Radioprotection

69 , rue de Micromeshil

75008 Paris

FRANCE
No. of

Copies

J. F. Olivier

ENEA (OECD) Health and

Safety office

38 , Blvd. Suchet

Paris IVI

FRANCE

M. Rzekiecki

Commissariat a l'Energie Atomique

Centre d' Etudes

Nuc leaires de Cadarache

BP n 13-St. Paul

Les Durance

FRANCE

A. R. Gopal-Ayengar

Inst. fur Biophysik

Herrenhauser Str. 2

3000 Hannover, 21

FEDERAL REPUBLIC OF GERMANY

W. Jacobi

Institut fur

Strahlenschutz

D-8042 Neuherberg

Ingo lstaddter

Landstrasse 1

FEDERAL REPUBLIC OF GERMANY

L. Feinendegen

Director of Institute of Medicine

Institut fur Medizin

Kernforchung sanlage Julich

Postfach 1913

517, Julich

FEDERAL REPUBLIC OF GERMANY

Dr. Vittorio Prodi

Comitato Nazionale per L'Energia Nuc leare

Laboratorio Fisica Sanitaria

Posiz.

Prot.n. 306/LFS

Via Miazzini, 2

40138 Bologna

ITALY 
No. of Copies

T. Kumatori

Director

National Institute of Radiological Sciences

4-9-1, Anagawa

Chiba-shi, Chiba 260 JAPAN

Z. M. Beekman

President of IRPA

Roosevelt laan 197

1079 AP Amsterdam

THE NETHERLANDS

J. K. Basson, Vice-President

Raad Op Atomic

Atoomkrag Energy Board

Privaatsk X 256

Pretoria 0001

REPUBLIC OF SOUTH AFRICA

A. Brink

Sasol-One Limited

P.0. Box 1

Sasolburg 9570

REPUBLIC OF SOUTH AFRICA

B. C. Winkler

Director, Licensing (Standards)

Raad Op Atoomlrag/Atomic Energy Board

Privaatsak $X 256 /$

Private $\mathrm{Bag} \times 256$

Pretoria 001

REPUBLIC OF SOUTH AFRICA

E. Komarov

Environmental Health Division

World 0rg.

Avenue Appia 1211

Geneva 27

SWITZERLAND

K. E. Lennart Johansson National Defense Research Institute

FOA 451

S-901-82

Umea, SWEDEN

D. Djuric

Institute of Occupational and Radiological Health

11000 Beograd

Deligradska 29 ,

YUGOSLAVIA
No. of

Copies

Individuals

E. L. Alpen

Donner Laboratory

University of California

Berkeley, CA 94720

G. Anderson

Dept. of Oceanography

University of Washington

Seattle, WA 98115

D. Baumgartner

Environmental Protection Agency

NERC

200 S.W. 35th

Corvallis, OR

97330

V. T. Bowen

Woods Hole Oceanographic Inst itute

Woods Hole, MA 02543

Wallace Broecker

Lamont Geological Observatory

Columbia University

Palisades, NY 10964

G. W. Brown, Jr.

College of Fisheries University of Washington Seattle, WA 98115

J. T. Callahan

Associate Program Director

Ecosystems Studies Program

National Science Foundation

Washington, DC 20545

Douglas Chapman, Dean

College of $F$ isheries

University of Washington

Seattle, WA 98115

Gordon Chesters, Director Water Resources Center University of Wisconsin Madison, WI 53706
R. Eppley
Scripps Institute of Oceanography
La Jolla, CA 92307

No. of

Copies

Arnold Gahler

Environmental Protection Agency

Region $X$ Laboratory

P.0. Box 549

Manchester, WA 98353

Norman R. Glass, Director

Environmental Protection Agency

NERC

200 S.W. 35th Street

Corvallis, OR 97330

Ed Goldberg

Scripps Institute of Oceanography

La Jolla, CA 92307

Jack R. Gould

American Petroleum Institute

1801 K Street N.W.

Washington, DC 20006

D. W. Hayne

Department of Experimental Statistics North Carolina State University

Box 5457

Raleigh, NC 27607

Edward Held

Nuc lear Regulatory Commission

Washington, DC 20545

Thomas Kimball

Executive Director

National Wildlife Federation

1412 Sixteenth Street NW Washington, DC 20036

D. Malins

National Marine Fisheries

University of Washington

Seattle, WA 98115

Bernard Manowitz

Energy and Environment Division

Brookhaven National Laboratory

Upton, Long Is land, NY 11973 
No. of

Copies

0. Doyle Markham

Radiological and

Environmental

Sciences Laboratory

U.S. DOE

P.0. Box 2108

Idaho Falls, ID 83401

D. Menzel

Skidaway Oceanographic Institute

University of Georgia

Savannah, GA 31406

K. Z. Morgan

School of Nuclear

Engineering

Georgia Institute of Technology

At lanta, GA 30332

Director

EPA Environmental Research Center 6201 Congdon Blvd.

Duluth, MN 55800

R. E. Nakatani

Assistant Director

Fisheries Research Institute

$260 \mathrm{Fisheries}$ Center University of Washington Seattle, WA 98115

Professor J. M. Neuhold

Department of Wildlife Resources

Utah State University

Logan, UT 84321

1. Ophel

Atomic Energy of Canada Ltd.

Chalk River, Ontario KJO IJO CANADA

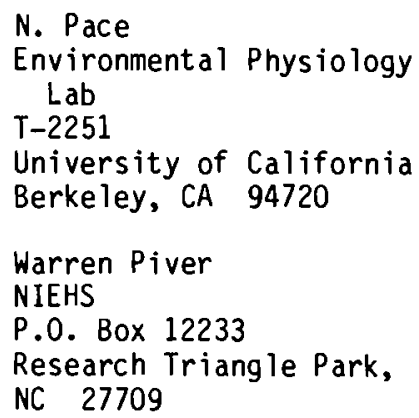

N. Pace

Environmental Physiology Lab

T-2251

University of California

Berkeley, CA 94720

Warren Piver

NIEHS

P.0. Box 12233

Research Triangle Park, NC 27709

No. of

Copies

Craig Roberts

Assistant Director

Site and Health Standards

Nuc lear Regulatory Commission

Washington, DC 20555

Vincent Schultz

Department of Zoology

Washington State University

Pullman, WA 99163

Regional Director

EPA Region Office

1206 6th Avenue

Seattle, WA 98101

Mike Smith, Director

Savannah River Ecology Laboratory

University of Georgia

Savannah River Plant

P.0. Box A

Aiken, SC 29801

L. F. Stickel

Patuxent Wildlife

Research Center

Laure 1, MD 20810

Lee 0. Tiff in

Swan Valley Route

Seeley Lake, MT 59868

E. W. Ungar, Director

Columbus Laboratories

Battelle Memorial Institute

$505 \mathrm{King}$ Avenue

Columbus, $\mathrm{OH} 43201$

R. C. Vetter

National Academy of Sciences

2101 Constitution Avenue

Washington, DC 20037

Charles L. Weaver, Director

Division of Environmental Radiation

Dept. of Health, Education and Welfare

Consumer Protection and Environmental Health Service

Rockville, MD 20852
No. of

Copies

Ward Whicker

Colorado State University

Fort Collins, CO 80521

9 DOE Richland Operations office

R. E. Aust in

P. F. Dunigan, Jr.

P. K. Clark/H. E. Ransom

D. E. Elle

P. G. Holsted

J. Rhoads

F. R. St anderfer

M. W. Tiernan

J. D. White

2 Rockwell Hanford Operations

R. D. Fox

P. G. Lorenzini

UNC Nuc lear Industries

T. E. Dabrowski

2 Westinghouse Hanford Company

R. 0. Budd

D. E. Simpson

2 Hanford Environmental Health Foundation

B. D. Breitenstein

B. D. Reinert

8 Battelle Seattle

S. M. Nealey

E. B. Perrin

J. E. Rasmussen

A. H. Schilling

C. R. Schuller

R. Shikiar

M. E. Walsh

M. T. Wood

6 Battelle Memorial Institute

N. E. Carter

L. German

R. S. Paul

D. B. Shipler

C. R. Vest

Librarian 
No. of

Copies

3 Battel le-Columbus

A. H. Adelman

A. D. Barker

F. J. Milford

3 Battelle-Washington DC office
G. Johnson
S. Stryker
C. Vest

204 Pacific Northwest Laboratory

R. W. Baalman (5)

W. J. Bair (15)

F. P. Braver

D. B. Cear lock

T. P. Chikalla

J. M. Davidson

H. Drucker
No. of

Copies

C. E. Elderkin

S. J. Farmer

J. J. Fuquay

C. I. Gibson (15)

W. A. Glass

R. H. Gray

C. R. Hann

A. J. Haverfield

I. D. Hays

A. F. Johnston

H. V. Larson

R. C. Liikala

S. Marks

R. P. Marshall

D. H. McKenzie (15)

J. E. Mendel

J. E. Minor

J. M. Nielson

R. E. Night ingale

C. M. Novich

D. E. Olesen

T. L. Page (15)
No. of

Copies

R. W. Perkins

A. M. Platt

W. D. Richmond

W. H. Rickard

G. F. Schiefelbein

L. C. Schmidt

J. B. Schuette

C. L. Simpson

M. E. Stifter

A. M. Sutey

W. L. Templeton (2)

R. C. Thompson

J. M. Thorp

B. E. Vaughan (50)

M. L. Warner (15)

E. C. Watson (10)

R. E. Wildung (15)

W. R. Wiley

L. D. Williams

Life Sciences Library (2)

Technical Information (5)

Publishing Coordination (2) 


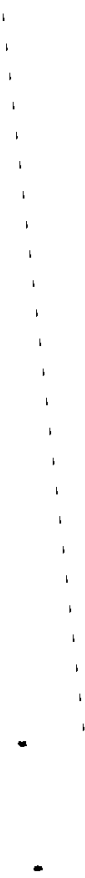

